\title{
Carbonylative C-C Bond Activation of Aminocyclopropanes Using a Temporary Directing Group Strategy
}

Gang-Wei Wang, ${ }^{++}$Olga O. Sokolova, ${ }^{++}$Tom. A. Young, ${ }^{\circledR}$ Ektor M. S. Christodoulou ${ }^{+}$Craig P. Butts, ${ }^{\dagger}$ and John F. Bower ${ }^{*}+\neq$

$\left({ }^{+}\right.$G.W. and O.O.S. contributed equally)

† School of Chemistry, University of Bristol, Bristol, BS8 1TS, United Kingdom

$\$$ Physical and Theoretical Laboratory, University of Oxford, Oxford, OX1 3QZ, United Kingdom

₹ Department of Chemistry, University of Liverpool, Crown Street, Liverpool, L69 7ZD, United Kingdom

\section{Supporting Information}

\section{Table of Contents}

General Experimental Details

General Experimental Procedures

Compound Data and Experimental Procedures

Calculations

Copies of ${ }^{1} \mathrm{H}$ and ${ }^{13} \mathrm{C}$ NMR Spectra for Novel Compounds$-\mathrm{S} 60$

Selected Reaction Optimization Result $-S 94$

References S94 
General Experimental Details. Starting materials sourced from commercial suppliers were used as received unless otherwise stated. Dry solvents, where necessary, were obtained by distillation using standard procedures or by passage through a column of anhydrous alumina using equipment from Anhydrous Engineering based on the Grubb's design. ${ }^{1}$ Petrol refers to the fraction of petroleum ether boiling in the range of $40-60{ }^{\circ} \mathrm{C}$. The removal of solvents in vacuo was achieved using both a Büchi rotary evaporator (bath temperatures up to $45^{\circ} \mathrm{C}$ ) at a pressure of either 15 $\mathrm{mmHg}$ (diaphragm pump) or $0.1 \mathrm{mmHg}$ (oil pump), as appropriate, and a high vacuum line at room temperature. Reactions requiring anhydrous conditions were run under an atmosphere of dry nitrogen or argon; glassware, syringes and needles were either flame dried immediately prior to use or placed in an oven $\left(200^{\circ} \mathrm{C}\right)$ for at least 2 hours and allowed to cool either in a desiccator or under an atmosphere of nitrogen or argon; liquid reagents, solutions or solvents were added via syringe through rubber septa; solid reagents were added via Schlenk type adapters. Commerically available Merck Kieselgel $60 \mathrm{~F}_{254}$ aluminium backed plates were used for TLC analysis. Visualization was achieved by either UV fluorescence, basic $\mathrm{KMnO}_{4}$ solution and heat. Flash column chromatography (FCC) was performed using silica gel (Aldrich 40-63 $\mu \mathrm{m}, 230-400 \mathrm{mesh}$ ). The crude material was applied to the column as a solution in $\mathrm{CH}_{2} \mathrm{Cl}_{2}$ or by pre-adsorption onto silica, as appropriate. Melting points were determined using a Reichert melting point table and temperature controller and are uncorrected. Infra-red spectra were recorded in the range 4000-600 $\mathrm{cm}^{-1}$ on a Perkin Elmer Spectrum either as neat films or solids compressed onto a diamond window. Abbreviations used are: w (weak), m (medium) or s (strong). NMR spectra were recorded using either a Varian $400 \mathrm{MHz}$ or Varian $500 \mathrm{MHz}$ spectrometer. Chemical shifts $(\delta)$ are quoted in parts per million (ppm), coupling constants $(J)$ are given in $\mathrm{Hz}$ to the nearest $0.5 \mathrm{~Hz}$. Other abbreviations used are s (singlet), d (doublet), t (triplet), m (multiplet) and br. (broad). ${ }^{1} \mathrm{H}$ and ${ }^{13} \mathrm{C}$ NMR spectra were referenced to the appropriate residual solvent peak. ${ }^{19} \mathrm{~F}$ spectra were referenced to $\mathrm{CCl}_{3} \mathrm{~F}$ as an external standard. Assignments of ${ }^{1} \mathrm{H}$ NMR and ${ }^{13} \mathrm{C}$ NMR signals were made, where possible, using COSY, HMQC, HMBC, and NOE experiments. Where mixtures of isomers (e.g. diastereomers and/or rotamers) have been characterized together, they are referred to as $A$ and $B$. Numbering systems for NMR signal assignments are specified on the structure and are not related to those used for the compound names. Mass spectra were determined by the University of Bristol mass spectrometry service by electron impact $\left(\mathrm{ESI}^{+}\right)$using a Bruker Daltonics FT-ICR-MS Apex 4e 7.0T FT-MS. 


\section{Experimental Procedures}

\section{General Procedure A for the $N$-alkylation of primary cyclopropylamines}

To a tube containing the specified tosylate $(100 \mathrm{~mol} \%)$ in acetonitrile $(0.40 \mathrm{M})$ was added cyclopropylamine (400 mol\%). The tube was sealed and heated at $90{ }^{\circ} \mathrm{C}$ for 16 hours. The reaction mixture was cooled to room temperature and concentrated in vacuo. Sat. aq. $\mathrm{NaHCO}_{3}(5$ $\mathrm{mL} / \mathrm{mmol})$ and $\mathrm{CH}_{2} \mathrm{Cl}_{2}(5 \mathrm{~mL} / \mathrm{mmol})$ were added, the layers were separated and the aqueous portion was further extracted with $\mathrm{CH}_{2} \mathrm{Cl}_{2}(2 \times 5 \mathrm{~mL} / \mathrm{mmol})$. The organic extracts were combined, washed with brine $(5 \mathrm{~mL} / \mathrm{mmol})$. The organic layer was dried over $\mathrm{Na}_{2} \mathrm{SO}_{4}$ and concentrated in vacuo. The residue was purified by flash column chromatography, under the conditions noted, to afford the desired $N$-substituted cyclopropylamine.

\section{General Procedure B for the formation of ureas and thioureas from isocyanate or isothiocyanate}

To a solution of amine $(100-110 \mathrm{~mol} \%)$ and $\mathrm{Et}_{3} \mathrm{~N}(110 \mathrm{~mol} \%)$ in $\mathrm{CH}_{2} \mathrm{Cl}_{2}(0.3 \mathrm{M})$ at $0{ }^{\circ} \mathrm{C}$ was added the specified isocyanate or isothiocyanate $(100-110 \mathrm{~mol} \%)$. The reaction mixture was warmed to room temperature and stirred for 18 hours. The solution was diluted with $\mathrm{CH}_{2} \mathrm{Cl}_{2}(3$ $\mathrm{mL} / \mathrm{mmol})$ and washed with water $(5 \mathrm{~mL} / \mathrm{mmol})$, aq. $1 \mathrm{M} \mathrm{HCl}(5 \mathrm{~mL} / \mathrm{mmol})$, sat. aq. $\mathrm{NaHCO}_{3}(5$ $\mathrm{mL} / \mathrm{mmol})$ and brine $(5 \mathrm{~mL} / \mathrm{mmol})$. The organic layer was dried over $\mathrm{Na}_{2} \mathrm{SO}_{4}$ and concentrated in vасио. The residue was purified by flash column chromatography, under the conditions noted, to afford the desired compound.

General Procedure C: To an oven dried reaction tube, fitted with a magnetic stirrer, was charged with $\left[\operatorname{Rh}(\operatorname{cod})_{2}\right]$ OTf (7.50 mol\%), acid additive (15.0-100 mol\%), triphenylphosphine (15.0 mol\%) and substrate $(100 \mathrm{~mol} \%)$. The tube was fitted with a rubber septum and purged with argon. Anhydrous 1,2-DCB (0.03-0.10 M) was added by syringe. The reaction vessel was purged with $\mathrm{CO}$ for 10 minutes and the solution was subsequently sparged with CO for approximately 20 seconds. The mixture was then heated at $130{ }^{\circ} \mathrm{C}$ for 72 hours, under a $\mathrm{CO}$ atmosphere (with $\mathrm{CO}$ balloon attached, $1 \mathrm{~atm})$. The mixture were cooled to room temperature and concentrated in vacuo. The residue was purified by flash column chromatography, under the conditions noted, to afford the desired product.

General Procedure D: To an oven dried reaction tube, fitted with a magnetic stirrer, was added amine substrates $(100 \mathrm{~mol} \%)$, cyclohexyl isocyanate (100 mol\%) and anhydrous 1,2-DCB (0.15 M) under argon. The mixture was then heated at $80{ }^{\circ} \mathrm{C}$ for 3 hours. The reaction was cooled to room temperature, $\left[\mathrm{Rh}(\mathrm{cod})_{2}\right] \mathrm{OTf}(7.50 \mathrm{~mol} \%)$, triphenylphosphine $(15.0 \mathrm{~mol} \%)$ and 4(dimethylamino)benzoic acid $(15.0 \mathrm{~mol} \%)$ were added to the tube under argon. Anhydrous 1,2- 
DCB $(0.10 \mathrm{M})$ was then added by syringe. The reaction vessel was purged with $\mathrm{CO}$ for 10 minutes and the solution was subsequently sparged with $\mathrm{CO}$ for approximately 20 seconds. The mixture was then heated at the $130{ }^{\circ} \mathrm{C}$ for 20 hours, under a $\mathrm{CO}$ atmosphere (with $\mathrm{CO}$ balloon attached, 1 atm). The mixture was cooled to room temperature and concentrated in vacuo. The residue was purified by flash column chromatography, under the conditions noted, to afford the desired product.

The following compounds were prepared according to our previously reported method. ${ }^{1}$<smiles>O=C(NCc1ccccc1)N(Cc1ccccc1)C1CC1</smiles>

1aa, $81 \%$ Yield<smiles>NC(=O)N(Cc1ccccc1)C1CC1</smiles>

1ab, 37\% Yield<smiles>O=C(NC1CCCCC1)N(Cc1ccccc1)C1CC1</smiles>

1ac, $79 \%$ Yield<smiles>O=C(NC1CCCCC1)NC1CC1</smiles>

1b, 92\% Yield<smiles>COc1ccc(CCN(C(=O)NCc2ccccc2)C2CC2)cc1OC</smiles>

1f, 92\% Yield 1c, $89 \%$ Yield<smiles>O=C1CC=CN(Cc2ccccc2)C(=O)N1Cc1ccccc1</smiles><smiles>O=C1CC=CN(Cc2ccccc2)C(=O)N1</smiles>

2ab, 54\% Yield<smiles>C[C@H]1C=CN(Cc2ccccc2)C(=O)N(Cc2ccccc2)C1=O</smiles><smiles>CCCCC1=CN(Cc2ccccc2)C(=O)N(Cc2ccccc2)C(=O)C1</smiles>

2d, 64\% Yield<smiles>O=C1CC=CN(CCc2ccsc2)C(=O)N1Cc1ccccc1</smiles>

2e, 92\% Yield<smiles>O=C1CCCNC(=O)N1C1CCCCC1</smiles>

3b, $67 \%$ Yield<smiles>COc1ccc(CCN2C=CCC(=O)N(Cc3ccccc3)C2=O)cc1OC</smiles>

2f, $77 \%$ Yield 


\section{Compound Data and Experimental Procedures}

\section{Refer to Scheme 2 in the main paper}

Scheme 2B, Eqn 1:

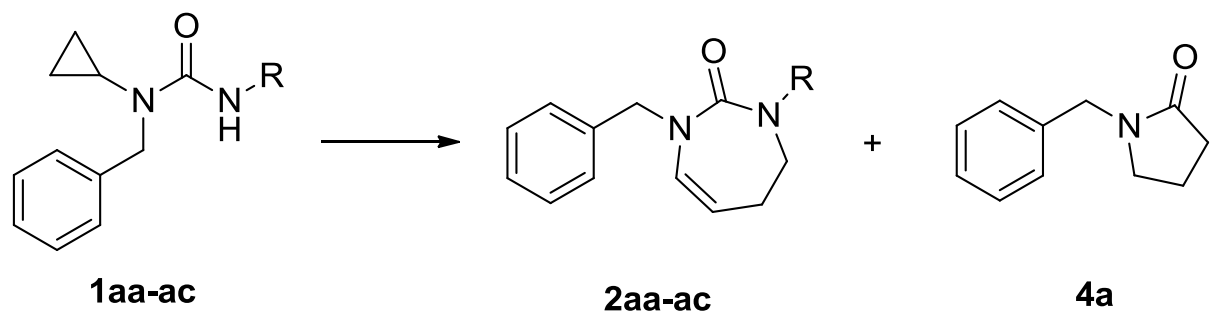

\begin{tabular}{|c|c|c|c|}
\hline $\mathrm{T}\left({ }^{\circ} \mathrm{C}\right)$ & Substrate 1 & Yield of 2 & Yield of 4a \\
\hline 130 & 1aa & 2aa, 73\% & $9 \%$ \\
\hline 130 & 1ab & 2ab, 30\% & $4 \%$ \\
\hline 130 & 1ac & 2ac, 52\% & $18 \%$ \\
\hline $100^{\mathrm{a}}$ & 1aa & 2aa, 68\% & $0 \%$ \\
\hline
\end{tabular}

${ }^{\text {a }} 6 \%$ of saturated azepine 3aa was detected in the system.

Three identical, oven dried reaction tubes were fitted with magnetic stirrers and charged with $\left[\mathrm{Rh}(\operatorname{cod})_{2}\right] \mathrm{OTf}(3.52 \mathrm{mg}, 7.50 \mu \mathrm{mol}), 4$-(dimethylamino)benzoic acid $(2.48 \mathrm{mg}, 15.0 \mu \mathrm{mol})$ and triphenylphosphine $(3.93 \mathrm{mg}, 15.0 \mu \mathrm{mol})$. Compounds 1aa $(28.0 \mathrm{mg}, 0.10 \mathrm{mmol}), \mathbf{1 a b}(19.0 \mathrm{mg}$, $0.10 \mathrm{mmol}), 1 \mathrm{ac}(27.2 \mathrm{mg}, 0.10 \mathrm{mmol})$ were added to each tube, respectively. Each tube was fitted with a rubber septum and purged with argon. Anhydrous 1,2-DCB $(2.00 \mathrm{~mL})$ was added by syringe. The reaction vessels were purged with $\mathrm{CO}$ for 10 minutes and the solutions were subsequently sparged with $\mathrm{CO}$ for approximately 20 seconds. The reaction tubes were heated at $130{ }^{\circ} \mathrm{C}$, under a $\mathrm{CO}$ atmosphere (with $\mathrm{CO}$ balloon attached, $1 \mathrm{~atm}$ ) for 72 hours. The mixtures were cooled to room temperature and concentrated in vacuo. The in-situ yields of product 2aa, 2ab, 2ac and 4a were determined by ${ }^{1} \mathrm{H}$ NMR analysis using 1,4-dinitrobenzene as an internal standard. An additional experiment was carried out using 1aa $(28.0 \mathrm{mg}, 0.10 \mathrm{mmol})$ as the starting material under the same conditions as above, but heating at $100{ }^{\circ} \mathrm{C}$.

Scheme 2B, Eqn 2:

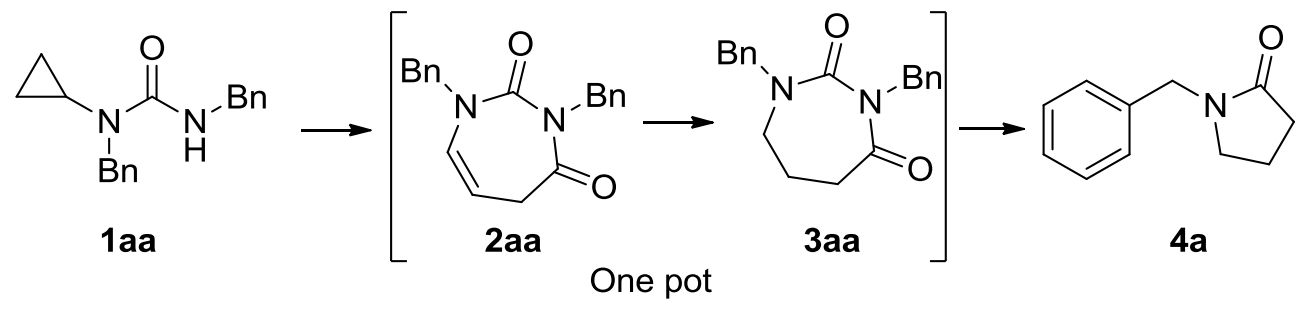


To an oven dried reaction tube, fitted with a magnetic stirrer and charged with $\left[\mathrm{Rh}(\operatorname{cod})_{2}\right] \mathrm{OTf}(3.52$ $\mathrm{mg}, 7.50 \mu \mathrm{mol})$, triphenylphosphine $(3.93 \mathrm{mg}, 15.0 \mu \mathrm{mol})$, 4-(dimethylamino)benzoic acid (2.48 $\mathrm{mg}, 15.0 \mu \mathrm{mol})$ and compound $1 \mathrm{aa}(28.0 \mathrm{mg}, 0.10 \mathrm{mmol})$. The tube was fitted with a rubber septum and purged with argon. Anhydrous 1,2-DCB $(2.00 \mathrm{~mL})$ was added by syringe. The reaction vessel was purged with $\mathrm{CO}$ for 10 minutes and the solution was subsequently sparged with $\mathrm{CO}$ for approximately 20 seconds. The reaction was heated at $130{ }^{\circ} \mathrm{C}$ under a $\mathrm{CO}$ atmosphere (with $\mathrm{CO}$ balloon attached, $1 \mathrm{~atm}$ ) for 72 hours. Then the mixture was cooled to room temperature and Xantphos (4,5-bis(diphenylphosphino)-9,9-dimethylxanthene) $(8.67 \mathrm{mg}, 15.0 \mu \mathrm{mol})$ was added. The resulting solution was sparged with hydrogen for approximately 60 seconds. The solution was heated under a $\mathrm{H}_{2}$ atmosphere (with $\mathrm{H}_{2}$ balloon attached, 1 atm) at $140{ }^{\circ} \mathrm{C}$ for 36 hours. The mixture was cooled to room temperature and concentrated in vacuo. The residue was purified by flash column chromatography (75\% EtOAc/Hexane) to afford compound $\mathbf{4 a}(13.1 \mathrm{mg}, 75 \%)$ as a yellow oil. ${ }^{1} \mathrm{H}$ NMR $\left(400 \mathrm{MHz}, \mathrm{CDCl}_{3}\right): \delta 7.35-7.25(\mathrm{~m}, 5 \mathrm{H}), 4.45(\mathrm{~s}, 2 \mathrm{H}), 3.26(\mathrm{t}, J=7.2 \mathrm{~Hz}$, $2 \mathrm{H}), 2.45(\mathrm{t}, J=8.2 \mathrm{~Hz}, 2 \mathrm{H}), 1.99(\mathrm{tt}, J=8.2,7.2 \mathrm{~Hz}, 2 \mathrm{H}) ;{ }^{13} \mathrm{C} \mathrm{NMR}\left(100 \mathrm{MHz}, \mathrm{CDCl}_{3}\right): \delta 174.9$, 136.6, 128.6, 128.1, 127.5, 46.6, 46.5, 30.9, 17.7. The spectroscopic properties of this compound were consistent with the data available in the literature. ${ }^{2}$

Scheme 2B, Eqn 3:

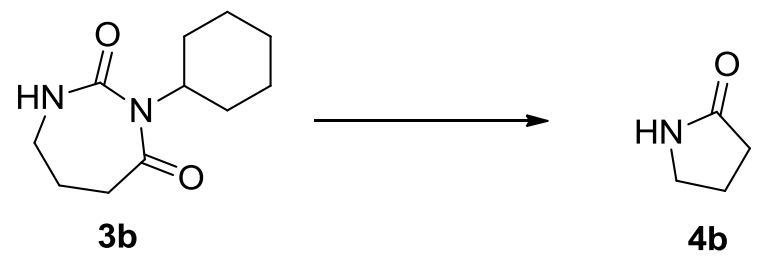

To an oven dried reaction tube, fitted with a magnetic stirrer, was charged with compound $\mathbf{3 b}$ (21.0 $\mathrm{mg}, 0.10 \mathrm{mmol})$. The tube was fitted with a rubber septum and purged with argon. Anhydrous 1,2DCB $(2.00 \mathrm{~mL})$ was added by syringe and the reaction was heated at $130{ }^{\circ} \mathrm{C}$ for 24 hours. The solution was cooled to room temperature and concentrated in vacuo. The crude mixture was analyzed by ${ }^{1} \mathrm{H}$ NMR using 1,4-dinitrobenzene as an internal standard, indicating that there was no $\mathbf{4 b}$ generated, and starting material $\mathbf{3 b}$ was recovered in $92 \%$ yield. 


\section{Scheme 2B, Eqn 4:}

1-Benzyl-3-cyclohexyl-1-cyclopropylthiourea 1ad

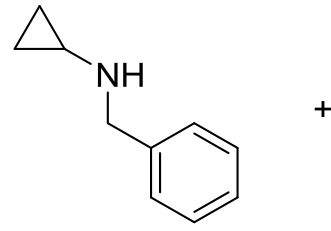

$5 a$<smiles>S=C=NC1CCCCC1</smiles>

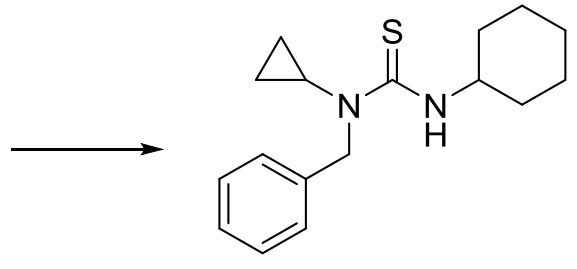

$1 \mathrm{ad}$

General procedure B: Compound 5a $(485 \mathrm{mg}, 3.30 \mathrm{mmol})$ and cyclohexyl isothiocyanate $(0.42$ $\mathrm{mL}, 3.00 \mathrm{mmol}$ ) were employed. The crude mixture was purified by flash column chromatography (10\% EtOAc/Hexane) to afford the title compound 1ad (357 mg, 75\%) as a colorless solid; m.p. 137-139 ${ }^{\circ} \mathrm{C}$ (Hexane/EtOAc); $v_{\max } / \mathrm{cm}^{-1}: 3440$ (m), 2928 (m), 1514 (s), 1373 (s), 1352 (s), 1029 (m); ${ }^{1} \mathrm{H}$ NMR (400 MHz, $\left.\mathrm{CDCl}_{3}\right): \delta 7.32-7.22(\mathrm{~m}, 5 \mathrm{H}), 6.46(\mathrm{~d}, J=8.0 \mathrm{~Hz}, 1 \mathrm{H}), 5.24(\mathrm{~s}, 2 \mathrm{H})$, $4.40(\mathrm{dtt}, J=10.6,8.0,4.3 \mathrm{~Hz}, 1 \mathrm{H}), 2.36(\mathrm{ddd}, J=10.0,5.1,3.3 \mathrm{~Hz}, 1 \mathrm{H}), 2.19-2.08(\mathrm{~m}, 2 \mathrm{H})$, $1.74-1.59(\mathrm{~m}, 3 \mathrm{H}), 1.52-1.37(\mathrm{~m}, 2 \mathrm{H}), 1.31-1.16(\mathrm{~m}, 3 \mathrm{H}), 0.92-0.76(\mathrm{~m}, 4 \mathrm{H}) ;{ }^{13} \mathrm{C} \mathrm{NMR}(100$ $\left.\mathrm{MHz}, \mathrm{CDCl}_{3}\right): \delta 182.6,138.1,128.4,127.5,127.0,55.3,54.0,33.0,28.6,25.6,24.7,8.8 ; \mathrm{m} / \mathrm{z}$ $\left(\mathrm{ESI}^{+}\right.$) HRMS: Calculated for $\mathrm{C}_{17} \mathrm{H}_{25} \mathrm{~N}_{2} \mathrm{~S}: 289.1733$. Found $[\mathrm{M}+\mathrm{H}]^{+}: 289.1724$.<smiles>S=C(NC1CCCCC1)N(Cc1ccccc1)C1CC1</smiles>

1 ad<smiles>O=C1CCCN1Cc1ccccc1</smiles>

$4 a$

General procedure C: Compound 1ad $(28.8 \mathrm{mg}, 0.10 \mathrm{mmol}), 3$-phenoxypropanoic acid (16.6 $\mathrm{mg}, 0.10 \mathrm{mmol})$ and anhydrous 1,2-DCB $(3.50 \mathrm{ml})$ were employed. The crude mixture was purified by flash column chromatography (75\% EtOAc/Hexane) to afford the title compound $4 \mathbf{a}$ (12.0 mg, 68\%) as a yellow oil;

Scheme 2B, Eqn 5:<smiles>O=C1CCCN1Cc1ccccc1CC1CCCCC1N=C=S</smiles> 
To an oven dried reaction tube, fitted with a magnetic stirrer and charged with compound 5a (22.0 $\mathrm{mg}, 0.15 \mathrm{mmol})$, cyclohexyl isothiocyanate $6(21.2 \mathrm{mg}, 0.15 \mathrm{mmol})$ and anhydrous 1,2-DCB (1.50 $\mathrm{mL}$ ) under argon. The mixture was then heated at $80{ }^{\circ} \mathrm{C}$ for 3 hours. The reaction was cooled to room temperature, $\left[\mathrm{Rh}(\operatorname{cod})_{2}\right] \mathrm{OTf}(5.28 \mathrm{mg}, 11.5 \mu \mathrm{mol})$, triphenylphosphine (5.90 mg, $\left.22.5 \mu \mathrm{mol}\right)$ and 3-phenoxypropanoic acid $(45.6 \mathrm{mg}, 0.30 \mathrm{mmol})$ were added to the tube under argon. Anhydrous 1,2-DCB (3.00 mL) was then added by syringe. The reaction vessel was purged with $\mathrm{CO}$ for 10 minutes and the solution was subsequently sparged with CO for approximately 20 seconds. The mixture was then heated at the $130{ }^{\circ} \mathrm{C}$ for 20 hours, under a $\mathrm{CO}$ atmosphere (with $\mathrm{CO}$ balloon attached, $1 \mathrm{~atm})$. The mixture was cooled to room temperature and concentrated in vacuo. The crude mixture was purified by flash column chromatography (75\% EtOAc/Hexane) to afford $4 \mathbf{a}(18.4 \mathrm{mg}, 70 \%)$ as a yellow oil.

\section{Scheme 2C:}

\section{(S)-1-Benzyl-3-methylpyrrolidin-2-one 4c}

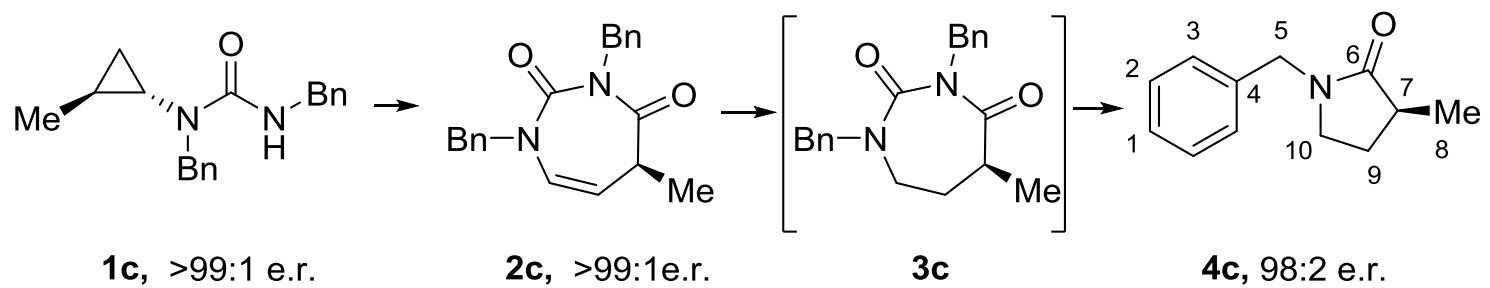

A solution of $2 \mathrm{c}(10.0 \mathrm{mg}, 0.03 \mathrm{mmol},>99: 1$ e.r., prepared according to the literature procedure from $\left.1 c^{1}\right)$ in $\mathrm{MeOH}(2.00 \mathrm{~mL})$ was added to $10 \% \mathrm{Pd} / \mathrm{C}(10.0 \mathrm{mg}, 100 \% \mathrm{w} / \mathrm{w})$ under an atmosphere of hydrogen. The reaction was stirred at room temperature for 3 hours under 1 atm of hydrogen. The mixture was then filtered through Celite ${ }^{\circledR}$ and concentrated in vacuo. The reduction product 3c was characterized by ${ }^{1} \mathrm{H}$ NMR analysis of the crude material. ${ }^{1} \mathrm{H} \mathrm{NMR}\left(\mathrm{CDCl}_{3}, 400 \mathrm{MHz}\right): \delta$ $7.40-7.34(\mathrm{~m}, 2 \mathrm{H}), 7.31-7.22(\mathrm{~m}, 6 \mathrm{H}), 7.11-7.03(\mathrm{~m}, 2 \mathrm{H}), 5.17(\mathrm{~d}, J=14.4 \mathrm{~Hz}, 1 \mathrm{H}), 4.77-$ $4.72(\mathrm{~m}, 2 \mathrm{H}), 4.46(\mathrm{~d}, J=14.8 \mathrm{~Hz}, 1 \mathrm{H}), 3.28(\mathrm{td}, J=14.2,5.7 \mathrm{~Hz}, 1 \mathrm{H}), 2.96(\mathrm{dd}, J=14.8,6.8 \mathrm{~Hz}$, 1H), $2.71(\mathrm{dt}, J=12.0,6.8 \mathrm{~Hz}, 1 \mathrm{H}), 2.03-1.87(\mathrm{~m}, 1 \mathrm{H}), 1.52(\mathrm{td}, J=12.5,5.7 \mathrm{~Hz}, 1 \mathrm{H}), 1.12(\mathrm{~d}$, $J=6.5 \mathrm{~Hz}, 3 \mathrm{H})$. The crude material was then dissolved in 1,2-DCB $(0.50 \mathrm{~mL})$ under argon and stirred at $160{ }^{\circ} \mathrm{C}$ for 65 hours. The mixture was cooled to room temperature and concentrated in vасио. The residue was purified by flash column chromatography (50\% EtOAc/Hexane) to afford 4c (5.60 mg, 95\%, over two steps) as a colorless oil; $v_{\max } / \mathrm{cm}^{-1}: 2929$ (m), 2871 (m), 1683 (s), 1454 (m), 1358 (s), 740 (s), 713 (s); ${ }^{1} \mathrm{H}$ NMR ( $\left.\mathrm{CDCl}_{3}, 400 \mathrm{MHz}\right): \delta 7.34-7.20$ (m, 5H, $2 \times \mathrm{C} 2-$ $\underline{\mathrm{H}}, 2 \times \mathrm{C} 3-\underline{\mathrm{H}}, 1 \times \mathrm{C} 1-\underline{\mathrm{H}}), 4.45\left(\mathrm{~d}, J=14.7 \mathrm{~Hz}, 1 \mathrm{H}, 1 \times \mathrm{C} 5-\underline{\mathrm{H}}_{2}\right), 4.40(\mathrm{~d}, J=14.7 \mathrm{~Hz}, 1 \mathrm{H}, 1 \times \mathrm{C} 5-$ $\left.\mathrm{H}_{2}\right), 3.19-3.12\left(\mathrm{~m}, 2 \mathrm{H}, 2 \times \mathrm{C10}-\underline{\mathrm{H}}_{2}\right), 2.55-2.44(\mathrm{~m}, 1 \mathrm{H}, 1 \times \mathrm{C} 7-\underline{\mathrm{H}}), 2.19(\mathrm{dddd}, J=12.9,8.7$, 
6.2, 4.7 Hz, $\left.1 \mathrm{H}, 1 \times \mathrm{C} 9-\underline{\mathrm{H}}_{2}\right), 1.64-1.51\left(\mathrm{~m}, 1 \mathrm{H}, 1 \times \mathrm{C} 9-\underline{\mathrm{H}}_{2}\right), 1.22\left(\mathrm{~d}, J=7.1 \mathrm{~Hz}, 3 \mathrm{H}, 3 \times \mathrm{C8}-\underline{\mathrm{H}}_{3}\right)$;

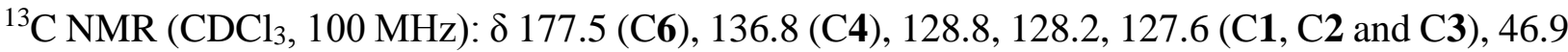
(C5), 44.8 (C10), 36.9 (C7), 27.2 (C9), 16.6 (C8). The spectroscopic properties of this compound were consistent with the data available in the literature. ${ }^{3}$

The enantiopurity of this compound was determined by chiral SFC analysis against a racemic standard (prepared according to the literature procedure ${ }^{4}$ ). Chiral SFC conditions: DAICEL CHIRALPAK-IA column $(25 \mathrm{~cm}), \mathrm{CO}_{2}: \mathrm{MeOH}=92: 8,2.0 \mathrm{~mL} / \mathrm{min}, 140$ bar, $40{ }^{\circ} \mathrm{C}$. Retention times: 3.6 minutes (major), 4.0 minutes (minor), e.r. $=98: 2$.
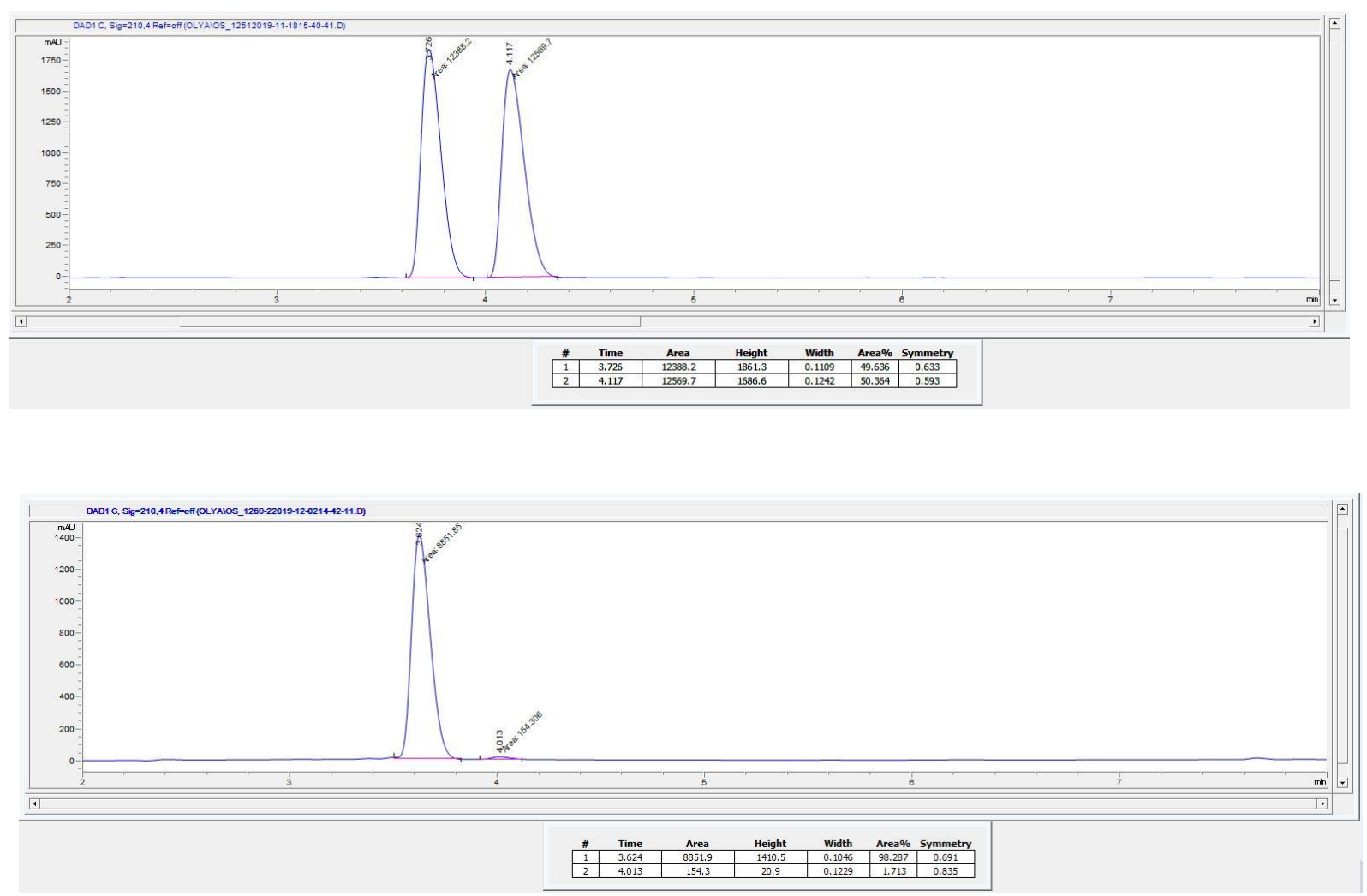

\section{1-Benzyl-4-butylpyrrolidin-2-one 4d}

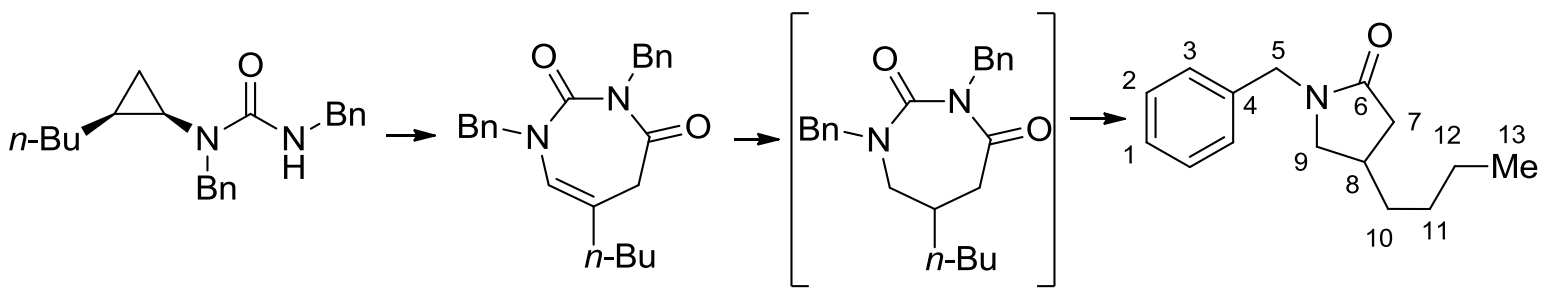

A solution of $\mathbf{2 d}$ ( $10.0 \mathrm{mg}, 0.03 \mathrm{mmol}$, prepared according to the literature procedure from $\left.\mathbf{1 d}^{1}\right)$ in $\mathrm{MeOH}(2.00 \mathrm{~mL})$ was added to $10 \% \mathrm{Pd} / \mathrm{C}(10.0 \mathrm{mg}, 100 \% \mathrm{w} / \mathrm{w})$ under an atmosphere of hydrogen. The reaction was stirred at room temperature for 24 hours under 1 atm of hydrogen. The mixture 
was then filtered through Celite ${ }^{\circledR}$ and concentrated in vacuo. Above hydrogenation process was then repeated twice. The reduction product $3 \mathbf{d}$ was characterized by ${ }^{1} \mathrm{H}$ NMR analysis of the crude material: ${ }^{1} \mathrm{H} \mathrm{NMR}\left(\mathrm{CDCl}_{3}, 400 \mathrm{MHz}\right): \delta 7.39-7.20(\mathrm{~m}, 8 \mathrm{H}), 6.99(\mathrm{dd}, J=6.5,2.9 \mathrm{~Hz}, 2 \mathrm{H}), 4.99$ $(\mathrm{d}, J=14.1 \mathrm{~Hz}, 1 \mathrm{H}), 4.89(\mathrm{~d}, J=14.1 \mathrm{~Hz}, 1 \mathrm{H}), 4.77$ (d, $J=14.9 \mathrm{~Hz}, 1 \mathrm{H}), 4.45$ (d, $J=14.9 \mathrm{~Hz}$, $1 \mathrm{H}), 3.13(\mathrm{dd}, J=14.7,6.1 \mathrm{~Hz}, 1 \mathrm{H}), 2.88(\mathrm{dd}, J=14.6,8.2 \mathrm{~Hz}, 1 \mathrm{H}), 2.66$ (dd, $J=12.5,7.3 \mathrm{~Hz}$, $1 \mathrm{H}), 2.36(\mathrm{dd}, J=12.5,5.2 \mathrm{~Hz}, 1 \mathrm{H}), 2.12-2.05(\mathrm{~m}, 1 \mathrm{H}), 1.37-1.10(\mathrm{~m}, 6 \mathrm{H}), 0.86(\mathrm{t}, J=6.7 \mathrm{~Hz}$, $3 \mathrm{H})$. The crude material was then dissolved in 1,2-DCB $(0.50 \mathrm{~mL})$ under argon and stirred at 160 ${ }^{\circ} \mathrm{C}$ for 65 hours. The mixture was cooled to room temperature and concentrated in vacuo. The residue was purified by flash column chromatography (50\% EtOAc/Hexane) to afford $\mathbf{4 d}(4.01$ $\mathrm{mg}, 63 \%$, over two steps) as a pale yellow oil; $v_{\max } / \mathrm{cm}^{-1}: 2925(\mathrm{~m}), 1690(\mathrm{~s}), 1425(\mathrm{~m}), 1268(\mathrm{~m})$, $701(\mathrm{~m}) ;{ }^{1} \mathrm{H}$ NMR $\left(\mathrm{CDCl}_{3}, 500 \mathrm{MHz}\right): \delta 7.35-7.21(\mathrm{~m}, 5 \mathrm{H}, 2 \times \mathrm{C} 2-\underline{\mathrm{H}}, 2 \times \mathrm{C} 3-\underline{\mathrm{H}}, 1 \times \mathrm{C} 1-\underline{\mathrm{H}}), 4.47$ $\left(\mathrm{d}, J=14.7 \mathrm{~Hz}, 1 \mathrm{H}, 1 \times \mathrm{C} 5-\underline{\mathrm{H}}_{2}\right), 4.41\left(\mathrm{~d}, J=14.7 \mathrm{~Hz}, 1 \mathrm{H}, 1 \times \mathrm{C5}^{-} \mathrm{H}_{2}\right), 3.33(\mathrm{dd}, J=9.7,8.0 \mathrm{~Hz}$, $\left.1 \mathrm{H}, 1 \times \mathrm{C} 9-\underline{\mathrm{H}}_{2}\right), 2.87\left(\mathrm{dd}, J=9.7,6.7 \mathrm{~Hz}, 1 \mathrm{H}, 1 \times \mathrm{C} 9-\mathrm{H}_{2}\right), 2.57(\mathrm{dd}, J=16.6,8.7 \mathrm{~Hz}, 1 \mathrm{H}, 1 \times \mathrm{C} 7-$ $\left.\underline{\mathrm{H}}_{2}\right), 2.32-2.2(\mathrm{~m}, 1 \mathrm{H}, 1 \times \mathrm{C} 8-\underline{\mathrm{H}}), 2.12\left(\mathrm{dd}, J=16.6,7.9 \mathrm{~Hz}, 1 \mathrm{H}, 1 \times \mathrm{C} 7-\mathrm{H}_{2}\right), 1.44-1.34(\mathrm{~m}, 2 \mathrm{H}$, $\left.2 \times \mathrm{C} 10-\underline{\mathrm{H}}_{2}\right), 1.31-1.17\left(\mathrm{~m}, 4 \mathrm{H}, 2 \times \mathrm{C11}-\underline{\mathrm{H}}_{2}, 2 \times \mathrm{C} 12-\underline{\mathrm{H}}_{2}\right), 0.87\left(\mathrm{t}, J=7.1 \mathrm{~Hz}, 3 \mathrm{H}, 3 \times \mathrm{C} 13-\underline{\mathrm{H}}_{3}\right)$; ${ }^{13} \mathrm{C} \mathrm{NMR}\left(\mathrm{CDCl}_{3}, 125 \mathrm{MHz}\right): \delta 174.7$ (C6), $136.8(\mathrm{C4}), 128.8,128.3$ (C2 and C3), $127.7(\mathrm{C1})$, 52.6 (C9), 46.6 (C5), 37.9 (C7), 34.6 (C10), 31.9 (C8), 29.7 (C11), 22.8 (C12), 14.1 (C13); HRMS: $\left(\mathrm{ESI}^{+}\right)$calculated for $\mathrm{C}_{15} \mathrm{H}_{22} \mathrm{NO}: 232.1696$, found $[\mathrm{M}+\mathrm{H}]^{+}: 232.1687$.

\section{Refer to Figure 1 and reference 15 in the main paper}

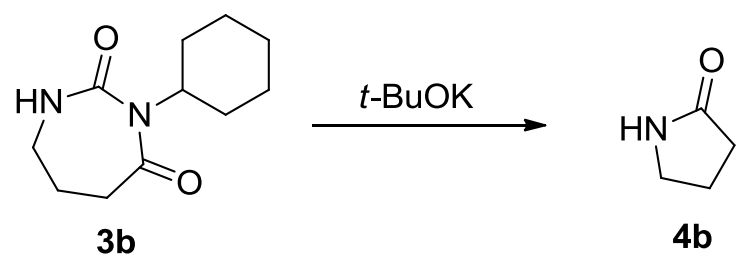

To an oven dried reaction tube, fitted with a magnetic stirrer was charged with compound $\mathbf{3 b}$ (21.0 $\mathrm{mg}, 0.10 \mathrm{mmol})$ and $t$-BuOK $(12.3 \mathrm{mg}, 0.11 \mathrm{mmol})$. The tube was fitted with a rubber septum and purged with argon. Anhydrous 1,2-DCB $(0.50 \mathrm{~mL})$ was added by syringe and the reaction was heated at $150{ }^{\circ} \mathrm{C}$ for 18 hours. The solution was then cooled to room temperature. Due to the expecting product $\mathbf{4 b}$ is volatile, a small portion of reaction mixture was directly analyzed by ${ }^{1} \mathrm{H}$ $\mathrm{NMR}$, indicating that $\mathbf{4 b}$ was generated, with a ratio of 2.2:1 against the recovered $\mathbf{3 b}$ in the reaction. The ${ }^{1} H$ NMR spectroscopic properties of $\mathbf{3} \boldsymbol{b}^{1}$ and $\mathbf{4} \boldsymbol{b}^{5}$ were consistent with the data available in the literature. 


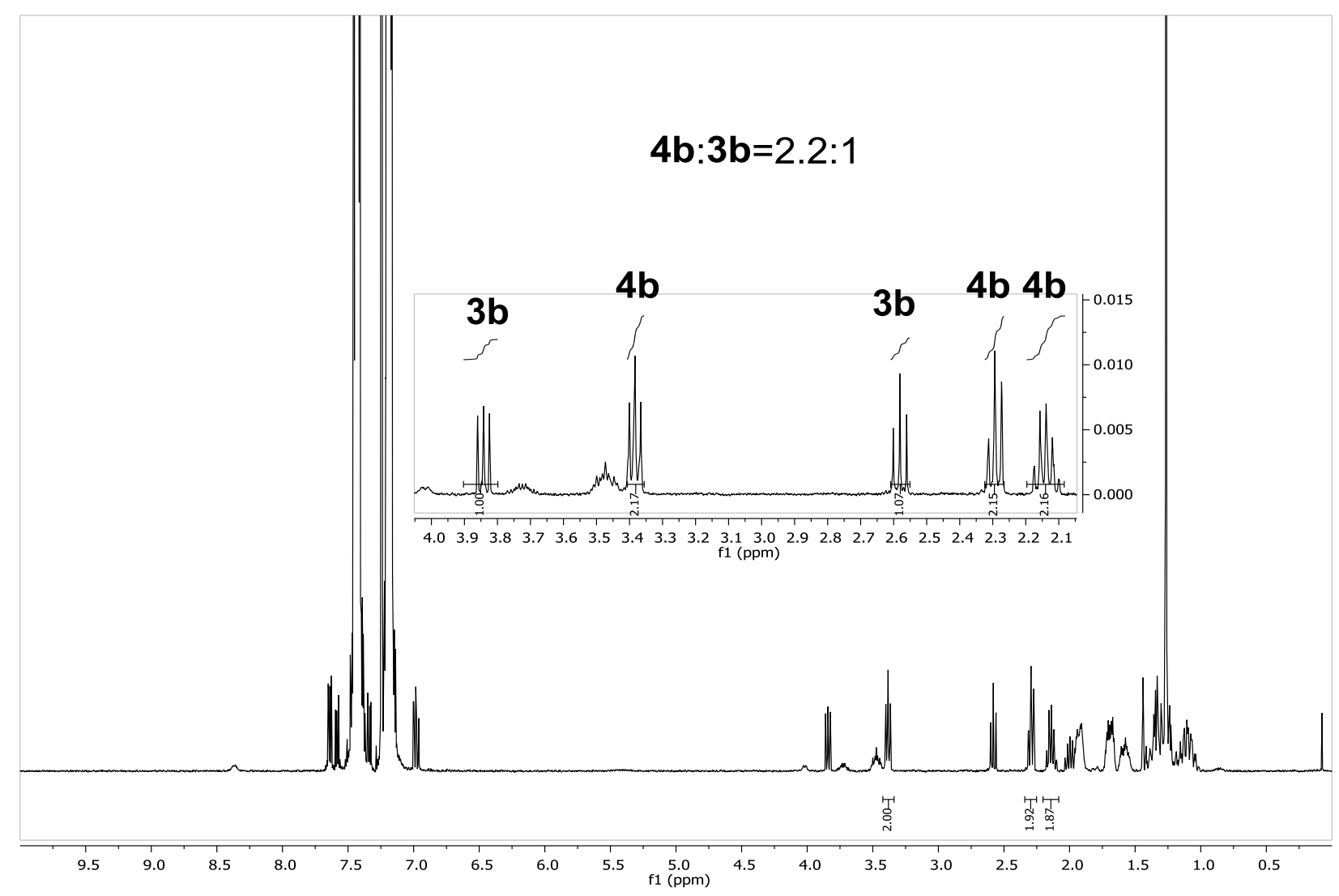

Refer to Scheme 3 in the main paper

Scheme 3A:

4,8,9,9a-Tetrahydrothieno[3,2-g]indolizin-7(5H)-one $4 \mathrm{e}$

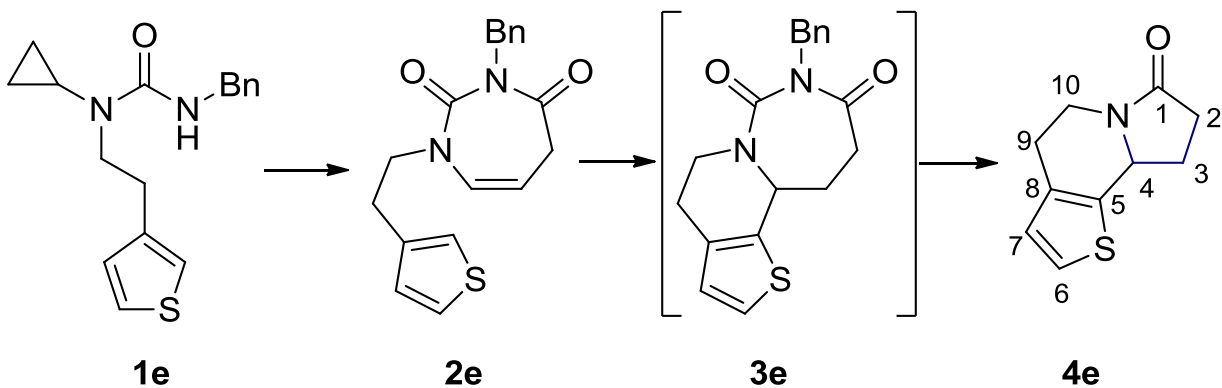

To an oven dried reaction tube, fitted with a magnetic stirrer, was added $\mathbf{2 e}$ (prepared according to the literature procedure from $\left.\mathbf{1 e}^{1}\right)(32.6 \mathrm{mg}, 0.10 \mathrm{mmol})$ and 1,2-DCB $(1.00 \mathrm{~mL})$. Trifluoroacetic acid $(76.0 \mu \mathrm{L}, 1.00 \mathrm{mmol})$ was added under argon. The mixture was then heated at $150{ }^{\circ} \mathrm{C}$ for 24 hours. The mixture was cooled to room temperature and concentrated in vacuo. The residue was purified by flash column chromatography (60\% EtOAc/Hexane) to afford the title compound $4 \mathbf{e}$ $(17.5 \mathrm{mg}, 91 \%)$ as a yellow oil; $v_{\max } / \mathrm{cm}^{-1}: 2922(\mathrm{~m}), 1680(\mathrm{~s}), 1415(\mathrm{~s}), 1360(\mathrm{~m}), 1307(\mathrm{~m}), 872$ $(\mathrm{m}) ;{ }^{1} \mathrm{H} \mathrm{NMR}\left(500 \mathrm{MHz}, \mathrm{CDCl}_{3}, 50^{\circ} \mathrm{C}\right): \delta 7.19(\mathrm{dd}, J=5.0,1.0 \mathrm{~Hz}, 1 \mathrm{H}, 1 \times \mathrm{C6}-\underline{\mathrm{H}}), 6.79(\mathrm{~d}, J=$ $5.0 \mathrm{~Hz}, 1 \mathrm{H}, 1 \times \mathrm{C} 7-\underline{\mathrm{H}}), 4.88-4.84(\mathrm{~m}, 1 \mathrm{H}, 1 \times \mathrm{C} 4-\underline{\mathrm{H}}), 4.43(\mathrm{ddd}, J=13.0,6.2,1.4 \mathrm{~Hz}, 1 \mathrm{H}, 1 \times$ 
C10- $\left.\underline{\mathrm{H}}_{2}\right), 2.98$ (dddd, $\left.J=13.0,11.4,5.1,1.4 \mathrm{~Hz}, 1 \mathrm{H}, 1 \times \mathrm{C10}-\underline{\mathrm{H}}_{2}\right), 2.82-2.67$ (m, $2 \mathrm{H}, 2 \times$ C9$\left.\underline{\mathrm{H}}_{2}\right), 2.62-2.42\left(\mathrm{~m}, 3 \mathrm{H}, 2 \times \mathrm{C} 2-\underline{\mathrm{H}}_{2}, 1 \times \mathrm{C} 3-\underline{\mathrm{H}}_{2}\right), 1.98-1.86\left(\mathrm{~m}, 1 \mathrm{H}, 1 \times \mathrm{C} 3-\underline{\mathrm{H}}_{2}\right) ;{ }^{13} \mathrm{C} \mathrm{NMR}(126$ MHz, $\left.\mathrm{CDCl}_{3}\right): \delta 173.1$ (C1), 136.0 (C5), 133.4 (C8), 127.1 (C7), 123.4 (C6), 55.8 (C4), 36.9 (C10), 31.5 (C2), 28.0 (C3), 25.3 (C9). $m / z$ (ESI ${ }^{+}$) HRMS: Calculated for $\mathrm{C}_{10} \mathrm{H}_{12} \mathrm{NOS}$ : 194.0634. Found $[\mathrm{M}+\mathrm{H}]^{+}: 194.0628$.

One pot manner: To an oven dried reaction tube, fitted with a magnetic stirrer, was added compound 1e $(45.0 \mathrm{mg}, 0.15 \mathrm{mmol})$, [Rh(cod) 2$] \mathrm{OTf}(1.73 \mathrm{mg}, 3.75 \mu \mathrm{mol})$, triphenylphosphine (1.97 $\mathrm{mg}, 7.50 \mu \mathrm{mol})$, benzoic acid $(1.83 \mathrm{mg}, 0.15 \mathrm{mmol})$ and anhydrous 1,2-DCB $(0.75 \mathrm{~mL})$ under argon. The reaction vessel was purged with $\mathrm{CO}$ for 10 minutes and the solution was subsequently sparged with CO for approximately 20 seconds. The mixture was then heated at the $100{ }^{\circ} \mathrm{C}$ for 30 hours, under a $\mathrm{CO}$ atmosphere (with $\mathrm{CO}$ balloon attached, $1 \mathrm{~atm}$ ). The mixture was cooled to room temperature and trifluoroacetic acid $(114 \mu \mathrm{L}, 1.50 \mathrm{mmol})$ was added. The mixture was then heated at $150{ }^{\circ} \mathrm{C}$ for 24 hours. The mixture was cooled to room temperature and concentrated in vacuo. The residue was purified by flash column chromatography (60\% EtOAc/Hexane) to afford the title compound $4 \mathbf{e}(20.3 \mathrm{mg}, 70 \%)$ as a yellow oil.

\section{8,9-Dimethoxy-1,5,6,10b-tetrahydropyrrolo[2,1-a]isoquinolin-3(2H)-one $4 \mathrm{f}$}

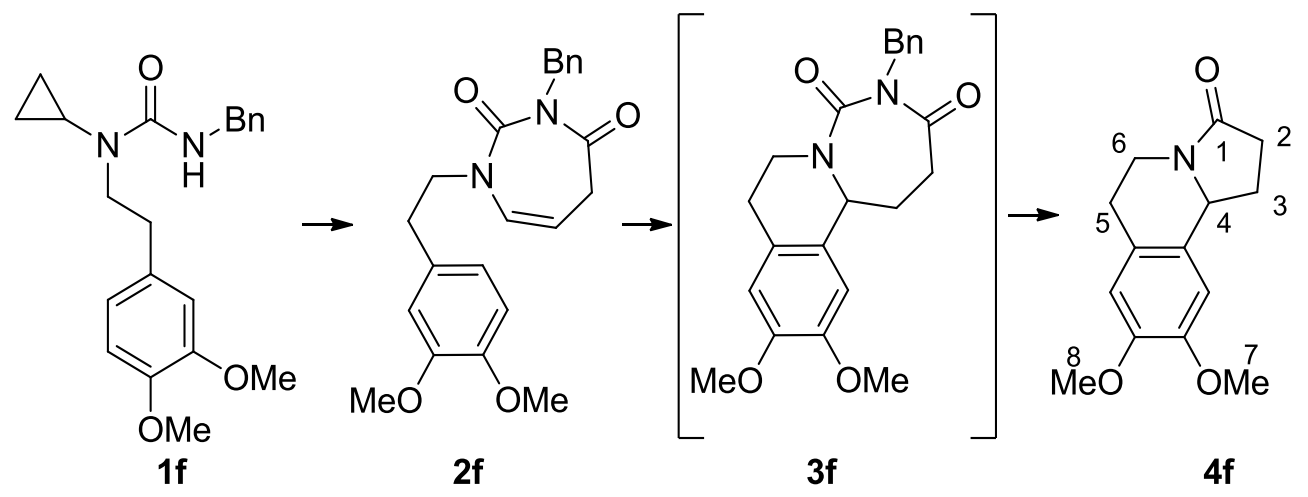

To an oven dried reaction tube, fitted with a magnetic stirrer, was added $\mathbf{2} \mathbf{f}$ (prepared according to the literature procedure from $\left.\mathbf{1 f}^{\mathbf{1}}\right)(38.0 \mathrm{mg}, 0.10 \mathrm{mmol})$ and 1,2-DCB $(1.00 \mathrm{~mL})$. Trifluoroacetic acid $(76.0 \mu \mathrm{L}, 1.00 \mathrm{mmol})$ was added under argon. The mixture was then heated at $150{ }^{\circ} \mathrm{C}$ for 24 hours. The mixture was cooled to room temperature and concentrated in vacuo. The residue was purified by flash column chromatography ( $100 \%$ EtOAc) to afford the title compound $\mathbf{4 f}(18.3 \mathrm{mg}$, $74 \%$ ) as a yellow oil; $v_{\max } / \mathrm{cm}^{-1}: 2933(\mathrm{~m}), 1679(\mathrm{~s}), 1514(\mathrm{~s}), 1255(\mathrm{~m}), 1117(\mathrm{~m}), 1008(\mathrm{~m}) ;{ }^{1} \mathrm{H}$ $\operatorname{NMR}\left(500 \mathrm{MHz}, \mathrm{CDCl}_{3}, 50{ }^{\circ} \mathrm{C}\right): \delta 6.63\left(\mathrm{~s}, 1 \mathrm{H}, 1 \times \mathrm{ArC}_{\mathrm{H}}\right), 6.59(\mathrm{~s}, 1 \mathrm{H}, 1 \times \mathrm{ArC} \underline{\mathrm{H}}), 4.72(\mathrm{dd}, J=$ 7.9, 7.9 Hz, 1H, $1 \times \mathrm{C} 4-\underline{\mathrm{H}}), 4.31\left(\mathrm{ddd}, J=12.7,6.1,2.2 \mathrm{~Hz}, 1 \mathrm{H}, 1 \times \mathrm{C} 6-\underline{\mathrm{H}}_{2}\right), 3.87-3.86(\mathrm{~m}, 6 \mathrm{H}$, $\left.3 \times \mathrm{C} 7-\underline{\mathrm{H}}_{3}, 3 \times \mathrm{C} 8-\underline{\mathrm{H}}_{3}\right), 3.03\left(\mathrm{dddd}, J=12.7,11.3,4.4,1.4 \mathrm{~Hz}, 1 \mathrm{H}, 1 \times \mathrm{C} 6-\underline{\mathrm{H}}_{2}\right), 2.94-2.85(\mathrm{~m}$, $\left.1 \mathrm{H}, 1 \times \mathrm{C} 5-\underline{\mathrm{H}}_{2}\right), 2.73-2.52\left(\mathrm{~m}, 3 \mathrm{H}, 1 \times \mathrm{C} 5-\underline{\mathrm{H}}_{2}, 1 \times \mathrm{C} 2-\underline{\mathrm{H}}_{2}, 1 \times \mathrm{C} 3-\underline{\mathrm{H}}_{2}\right), 2.50-2.41(\mathrm{~m}, 1 \mathrm{H}, 1 \times$ 
C2- $\left.\underline{\mathrm{H}}_{2}\right), 1.92-1.78\left(\mathrm{~m}, 1 \mathrm{H}, 1 \times \mathrm{C} 3-\underline{\mathrm{H}}_{2}\right) ;{ }^{13} \mathrm{C} \mathrm{NMR}\left(126 \mathrm{MHz}, \mathrm{CDCl}_{3}\right): \delta 173.1$ (C1), 148.1 (CAr), 147.9 (CAr), 129.3 (CAr), 125.5 (CAr), 111.6 (CAr), 107.6 (CAr), 56.5 (C4), 56.055 .9 (C7) (C8), 37.0 (C6), 31.8 (C2), 28.1 (C5), 27.8 (C3); m/z (ESI ${ }^{+}$) HRMS: Calculated for $\mathrm{C}_{14} \mathrm{H}_{18} \mathrm{NO}_{3}$ : 248.1281. Found $[\mathrm{M}+\mathrm{H}]^{+}: 248.1274$.

One pot manner: To an oven dried reaction tube, fitted with a magnetic stirrer, was added compound 1f $(53.1 \mathrm{mg}, 0.15 \mathrm{mmol})$, [Rh(cod $\left.)_{2}\right] \mathrm{OTf}(1.73 \mathrm{mg}, 3.75 \mu \mathrm{mol})$, triphenylphosphine (1.97 $\mathrm{mg}, 7.50 \mu \mathrm{mol})$, benzoic acid $(1.83 \mathrm{mg}, 0.15 \mathrm{mmol})$ and anhydrous 1,2-DCB $(0.75 \mathrm{~mL})$ under argon. The reaction vessel was purged with $\mathrm{CO}$ for 10 minutes and the solution was subsequently sparged with CO for approximately 20 seconds. The mixture was then heated at the $100{ }^{\circ} \mathrm{C}$ for 30 hours, under a $\mathrm{CO}$ atmosphere (with $\mathrm{CO}$ balloon attached, $1 \mathrm{~atm}$ ). The mixture was cooled to room temperature and trifluoroacetic acid $(114 \mu \mathrm{L}, 1.50 \mathrm{mmol})$ was added. The mixture was then heated at $150{ }^{\circ} \mathrm{C}$ for 24 hours. The mixture was cooled to room temperature and concentrated in vacuo. The residue was purified by flash column chromatography (60\% EtOAc/Hexane) to afford the title compound $\mathbf{4 f}(13.7 \mathrm{mg}, 37 \%)$ as a yellow oil.

\section{3-Benzyl-1-((1S*,2S*)-2-methylcyclopropyl)-1-(2-(thiophen-3-yl)ethyl)urea 1g}

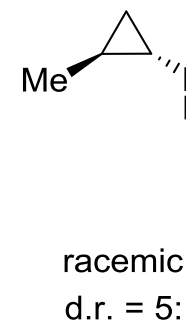

d.r. $=5: 1$

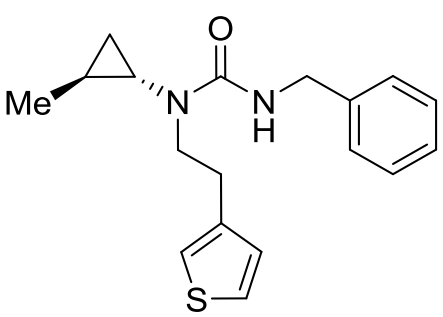

A

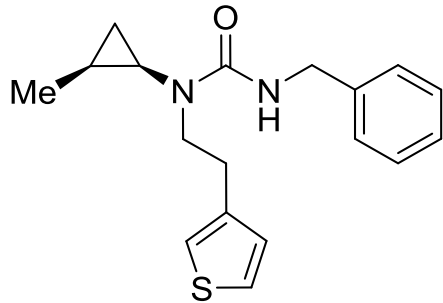

B

$1 \mathrm{~g}$

To a solution of tert-butyl ((1S*,2S*)-2-methylcyclopropyl)carbamate $(0.34 \mathrm{~g}, 2.00 \mathrm{mmol}$, d.r. $=$ 5:1, prepared according to the literature procedure $\left.{ }^{1}\right)$ in $\mathrm{CH}_{2} \mathrm{Cl}_{2}(2.00 \mathrm{~mL})$ was added trifluoroacetic acid $(1.53 \mathrm{~mL}, 20.0 \mathrm{mmol})$. The reaction was stirred at room temperature for 3 hours. The reaction mixture was concentrated in vacuo, water $(15 \mathrm{~mL})$ was then added to the residue, and the mixture was extracted with $\mathrm{CH}_{2} \mathrm{Cl}_{2}(15 \mathrm{~mL})$. The aqueous portion was adjusted to $\mathrm{pH} 12$ by addition of 2 $\mathrm{M}$ aq. $\mathrm{NaOH}$ and then extracted with $\mathrm{CH}_{2} \mathrm{Cl}_{2}(3 \times 10 \mathrm{~mL})$. The organic extracts were combined, dried over $\mathrm{Na}_{2} \mathrm{SO}_{4}$ and concentrated in vacuo. The residue was dissolved in acetonitrile $(9.00 \mathrm{~mL})$, $\mathrm{K}_{2} \mathrm{CO}_{3}(0.41 \mathrm{~g}, 3.00 \mathrm{mmol})$ and 2-(thiophen-3-yl)ethyl 4-methylbenzenesulfonate (0.56 g, 2.00 mmol, prepared according to the literature procedure ${ }^{1}$ ) were added under argon. The tube was sealed and the reaction was heated at $90{ }^{\circ} \mathrm{C}$ for 18 hours. The reaction was cooled to room temperature and concentrated in vacuo. The residue was then diluted with $\mathrm{CH}_{2} \mathrm{Cl}_{2}(20 \mathrm{~mL})$, washed 
with water $(30 \mathrm{~mL})$, the aqueous portion was further extracted with $\mathrm{CH}_{2} \mathrm{Cl}_{2}(2 \times 20 \mathrm{~mL})$. The organic extracts were combined, dried over $\mathrm{Na}_{2} \mathrm{SO}_{4}$ and concentrated in vacuo. The residue was dissolved in dry $\mathrm{CH}_{2} \mathrm{Cl}_{2}(5.00 \mathrm{~mL})$ and cooled down to $0{ }^{\circ} \mathrm{C}$. Triethylamine $(0.28 \mathrm{~mL}, 2.00 \mathrm{mmol})$ and benzyl isocyanate $(0.25 \mathrm{~mL}, 2.00 \mathrm{mmol})$ were added at $0{ }^{\circ} \mathrm{C}$. The reaction mixture was warmed to room temperature and stirred for 18 hours. The solution was diluted with $\mathrm{CH}_{2} \mathrm{Cl}_{2}(10$ $\mathrm{mL})$ and washed with water $(10 \mathrm{~mL})$, aq. $1 \mathrm{M} \mathrm{HCl}(10 \mathrm{~mL})$, sat. aq. $\mathrm{NaHCO}_{3}(10 \mathrm{~mL})$ and brine $(10 \mathrm{~mL})$. The organic layer was dried over $\mathrm{Na}_{2} \mathrm{SO}_{4}$ and concentrated in vacuo. The residue was purified by flash column chromatography (30-40\% EtOAc/Hexane) to afford the racemic $1 \mathbf{g}(0.29$ g, $46 \%$ over 3 steps) as a colorless oil. A mixture of diastereomers A and B were obtained in a 4:1 (A:B) ratio. A small portion of the major trans-diastereomer was isolated for SFC analysis by running a slow column.

Data for the mixture of diastereomers: $v_{\max } / \mathrm{cm}^{-1}: 2952$ (w), 1643 (s), 1509 (s), 1452 (m), 1285 (s), 728 (s), 698 (s); HRMS: $\left(\mathrm{ESI}^{+}\right)$calculated for $\mathrm{C}_{18} \mathrm{H}_{23} \mathrm{~N}_{2} \mathrm{OS}: 315.1526$, found $[\mathrm{M}+\mathrm{H}]^{+}$: 315.1518 .

Data for major trans-diastereomer 1g-A: ${ }^{1} \mathrm{H}$ NMR $\left(\mathrm{CDCl}_{3}, 400 \mathrm{MHz}\right): \delta 7.35-7.20(\mathrm{~m}, 6 \mathrm{H}) 7.01$ $-6.96(\mathrm{~m}, 2 \mathrm{H}), 5.37(\mathrm{t}, J=5.8 \mathrm{~Hz}, 1 \mathrm{H}), 4.48-4.43(\mathrm{~m}, 2 \mathrm{H}), 3.62(\mathrm{ddd}, J=14.4,8.0,6.6 \mathrm{~Hz}, 1 \mathrm{H})$, $3.52(\mathrm{ddd}, J=14.4,8.0,6.6 \mathrm{~Hz}, 1 \mathrm{H}), 2.94-2.88(\mathrm{~m}, 2 \mathrm{H}), 2.01-1.94(\mathrm{~m}, 1 \mathrm{H}), 1.02-0.93(\mathrm{~m}$, $4 \mathrm{H}), 0.80-0.73(\mathrm{~m}, 1 \mathrm{H}), 0.55-0.48(\mathrm{~m}, 1 \mathrm{H}) ;{ }^{13} \mathrm{C} \mathrm{NMR}\left(\mathrm{CDCl}_{3}, 100 \mathrm{MHz}\right): \delta 158.5,140.0,139.7$, $128.6,128.5,127.3,127.1,125.3,121.1,47.7,44.6,35.4,29.0,16.9,16.8,16.4$.

Data for minor cis-diastereomer 1g-B: Characteristic signals only: ${ }^{1} \mathrm{H} \mathrm{NMR}\left(\mathrm{CDCl}_{3}, 400 \mathrm{MHz}\right)$ : $\delta 5.46(\mathrm{t}, J=6.0 \mathrm{~Hz}, 1 \mathrm{H}), 3.87(\mathrm{ddd}, J=14.0,9.1,6.6 \mathrm{~Hz}, 1 \mathrm{H}), 3.35(\mathrm{ddd}, J=14.0,8.9,5.7 \mathrm{~Hz}$, $1 \mathrm{H}), 2.38-2.32(\mathrm{~m}, 1 \mathrm{H}), 0.40-0.27(\mathrm{~m}, 1 \mathrm{H}) ;{ }^{13} \mathrm{C} \mathrm{NMR}\left(\mathrm{CDCl}_{3}, 100 \mathrm{MHz}\right): \delta 159.1,139.9,139.7$, $128.5,127.6,125.3,48.1,32.7,14.7,13.4,12.5$.

\section{3-Benzyl-1-((1S,2S)-2-methylcyclopropyl)-1-(2-(thiophen-3-yl)ethyl)urea $1 \mathrm{~g}$}

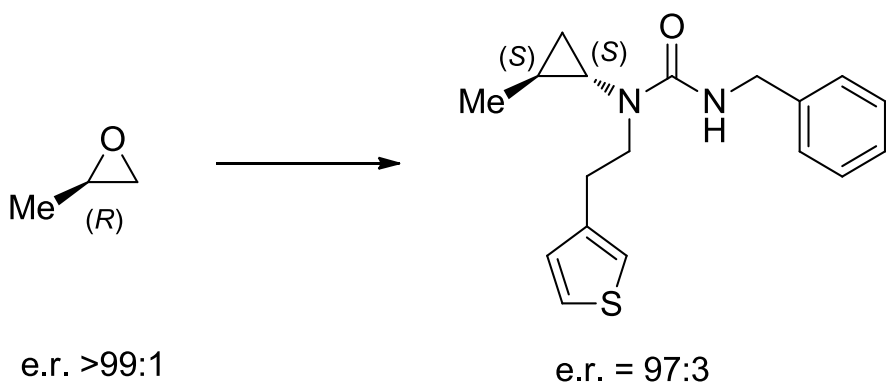

19 
Enantioenriched $1 \mathrm{~g}$ (97:3 e.r.) was obtained as a single diastereoisomer (>15:1 d.r.) by using enantioenriched $(R)$-propylene oxide (>99:1 e.r.) as starting material according to the literature procedure. $^{1,6}$

$[\alpha]_{\mathrm{D}}^{23.7}=+39.4\left(\mathrm{c}=0.22, \mathrm{CHCl}_{3}\right)$.

The enantiopurity of this compound was determined by chiral SFC analysis against a racemic standard. Chiral SFC conditions: DAICEL CHIRALPAK-IA column $(25 \mathrm{~cm}), \mathrm{CO}_{2}: \mathrm{MeOH}=$ 88:12, $2.0 \mathrm{~mL} / \mathrm{min}, 140 \mathrm{bar}, 40^{\circ} \mathrm{C}$. Retention times: 7.4 minutes (minor), 8.0 minutes (major), e.r. $=97: 3$.
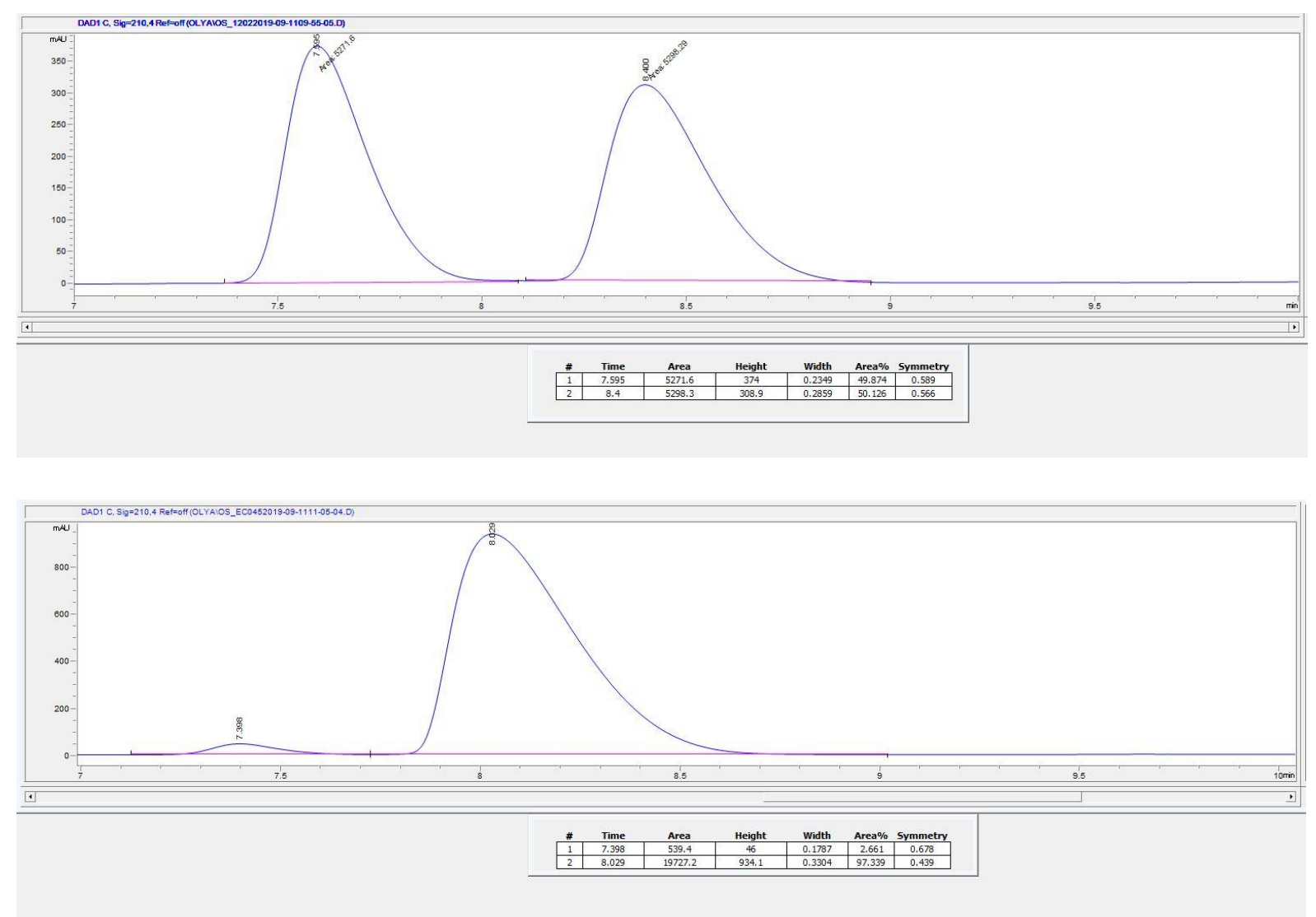

(S)-1-Benzyl-6-methyl-3-(2-(thiophen-3-yl)ethyl)-3,6-dihydro-1H-1,3-diazepine-2,7-dione $2 \mathrm{~g}$

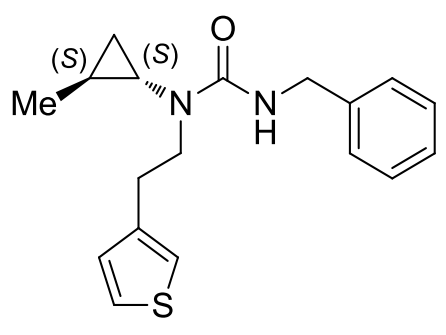

$1 \mathrm{~g}$, e.r. $=97: 3$

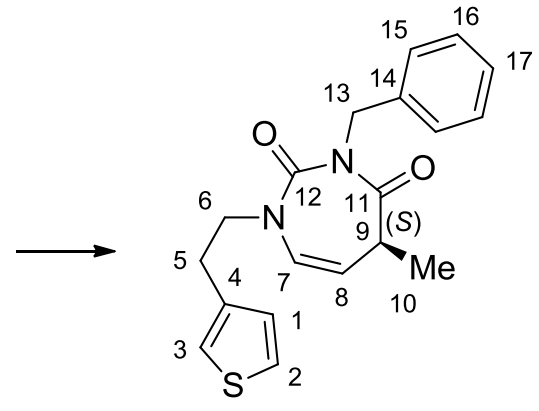

2g, e.r. $>99: 1$ 
To an oven dried reaction tube, fitted with a magnetic stirrer, was charged with $\mathbf{1 g}$ (47.2 $\mathrm{mg}, 0.15$ mmol, e.r. = 97:3), $\left[\mathrm{Rh}(\operatorname{cod})_{2}\right] \mathrm{BARF}(13.3 \mathrm{mg}, 11.5 \mu \mathrm{mol})$, triphenylphosphine $(5.92 \mathrm{mg}, 22.5$ $\mu \mathrm{mol})$ and benzoic acid $(2.70 \mathrm{mg}, 22.5 \mu \mathrm{mol})$. The tube was fitted with a rubber septum and purged with argon. Anhydrous 1,2-DCB $(0.75 \mathrm{~mL})$ was added via syringe. The reaction vessel was purged with $\mathrm{CO}$ for 10 minutes and then the solution was sparged with $\mathrm{CO}$ for approximately 20 seconds. The mixture was heated at $100{ }^{\circ} \mathrm{C}$ for 72 hours, under a $\mathrm{CO}$ atmosphere (with $\mathrm{CO}$ balloon attached, $1 \mathrm{~atm})$. The mixture was cooled to room temperature and concentrated in vacuo. The residue was purified by flash column chromatography (30\% EtOAc/Hexane) to afford the title compound $\mathbf{2 g}$ (34.3 mg, 67\%) as a pale brown oil; $v_{\max } / \mathrm{cm}^{-1}: 2936(\mathrm{w}), 1698(\mathrm{~m}), 1645(\mathrm{~s}), 1405(\mathrm{~m}), 1289(\mathrm{~m})$, 1189 (m), 723 (m), 697 (m); ${ }^{1} \mathrm{H}$ NMR $\left(\mathrm{CDCl}_{3}, 400 \mathrm{MHz}\right): \delta 7.31-7.20(\mathrm{~m}, 6 \mathrm{H}, 2 \times \mathrm{C15}-\underline{\mathrm{H}}, 2 \times$ C16- $\underline{\mathrm{H}}, 1 \times \mathrm{C} 17-\underline{\mathrm{H}}, 1 \times \mathrm{C} 2-\underline{\mathrm{H}}), 6.86(\mathrm{dd}, J=5.0,1.3 \mathrm{~Hz}, 1 \mathrm{H}, 1 \times \mathrm{C} 1-\underline{\mathrm{H}}), 6.79-6.77(\mathrm{~m}, 1 \mathrm{H}, 1 \times$ C3- $\underline{\mathrm{H}}), 5.72(\mathrm{dd}, J=6.9,2.0 \mathrm{~Hz}, 1 \mathrm{H}, 1 \times \mathrm{C} 7-\underline{\mathrm{H}}), 5.17\left(\mathrm{~d}, J=14.7 \mathrm{~Hz}, 1 \mathrm{H}, 1 \times \mathrm{C} 13-\underline{\mathrm{H}}_{2}\right), 5.08(\mathrm{dd}$, $J=6.9,6.0 \mathrm{~Hz}, 1 \mathrm{H}, 1 \times \mathrm{C} 8-\underline{\mathrm{H}}), 4.89\left(\mathrm{~d}, J=14.7 \mathrm{~Hz}, 1 \mathrm{H}, 1 \times \mathrm{C13}-\mathrm{H}_{2}\right), 4.00(\mathrm{ddd}, J=13.5,7.4$, $\left.7.4 \mathrm{~Hz}, 1 \mathrm{H}, 1 \times \mathrm{C6}-\underline{\mathrm{H}}_{2}\right), 3.60\left(\mathrm{ddd}, J=13.5,7.1,6.0 \mathrm{~Hz}, 1 \mathrm{H}, 1 \times \mathrm{C} 6-\mathrm{H}_{2}\right), 3.00-2.75(\mathrm{~m}, 3 \mathrm{H}, 1 \times$ C9- $\left.\underline{\mathrm{H}}, 2 \times \mathrm{C} 5-\underline{\mathrm{H}}_{2}\right), 1.28\left(\mathrm{~d}, J=6.8 \mathrm{~Hz}, 3 \mathrm{H}, 3 \times \mathrm{C10}-\underline{\mathrm{H}}_{3}\right) ;{ }^{13} \mathrm{C} \mathrm{NMR}\left(\mathrm{CDCl}_{3}, 100 \mathrm{MHz}\right): \delta 172.6$ (C11), 153.8 (C12), 138.4, 138.0 (C4, C14), 129.1, 128.5, 128.1, 128.1, 127.3, 126.0 (C1, C2, C7, C15, C16, C17), 122.0 (C3), 120.2 (C8), 50.8 (C6), 48.2 (C13), 37.9 (C9), 28.8 (C5), 13.7 (C10); HRMS: (ESI ${ }^{+}$) calculated for $\mathrm{C}_{19} \mathrm{H}_{21} \mathrm{~N}_{2} \mathrm{O}_{2} \mathrm{~S}: 341.1318$, found $[\mathrm{M}+\mathrm{H}]^{+}: 342.1316$.

$[\alpha]_{\mathrm{D}}^{23.2}=+192\left(\mathrm{c}=0.21, \mathrm{CHCl}_{3}\right)$.

The enantiopurity of this compound was determined by chiral SFC analysis against a racemic standard (prepared from racemic starting material $\mathbf{1 g}$ by using the same method as above). Chiral SFC conditions: DAICEL CHIRALPAK-IB column $(25 \mathrm{~cm}), \mathrm{CO}_{2}: \mathrm{MeOH}=96: 4,2.0 \mathrm{~mL} / \mathrm{min}$, 140 bar, $40{ }^{\circ} \mathrm{C}$. Retention times: 18.3 minutes (minor), 18.9 minutes (major), e.r. >99:1.

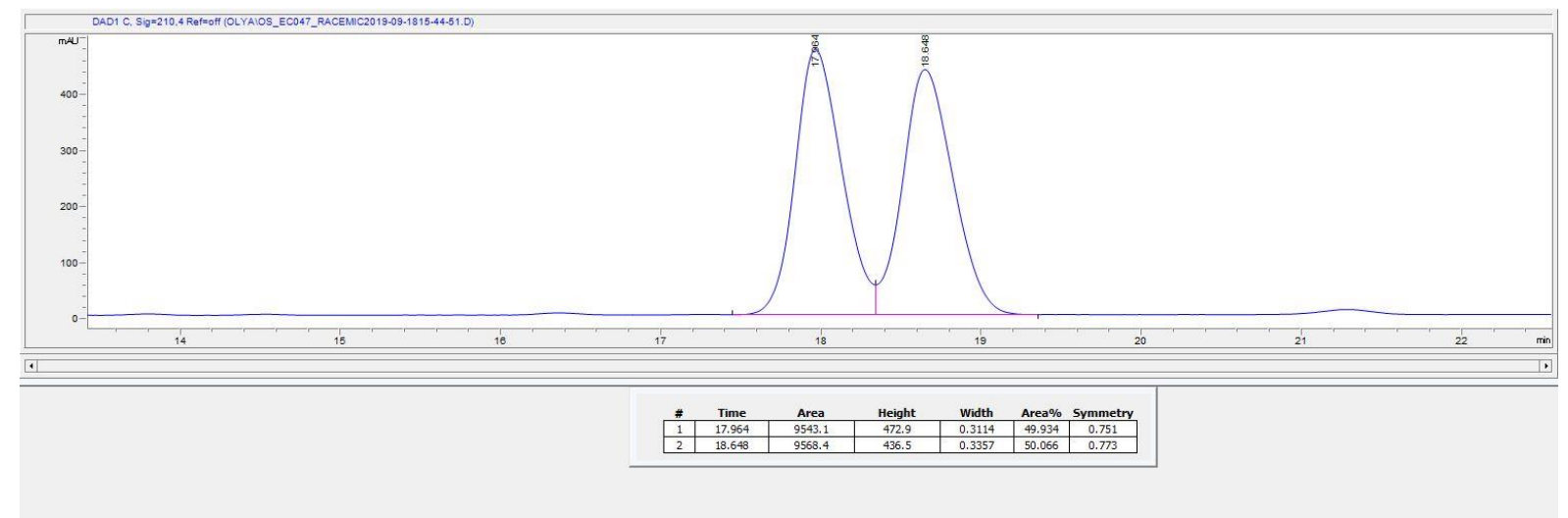




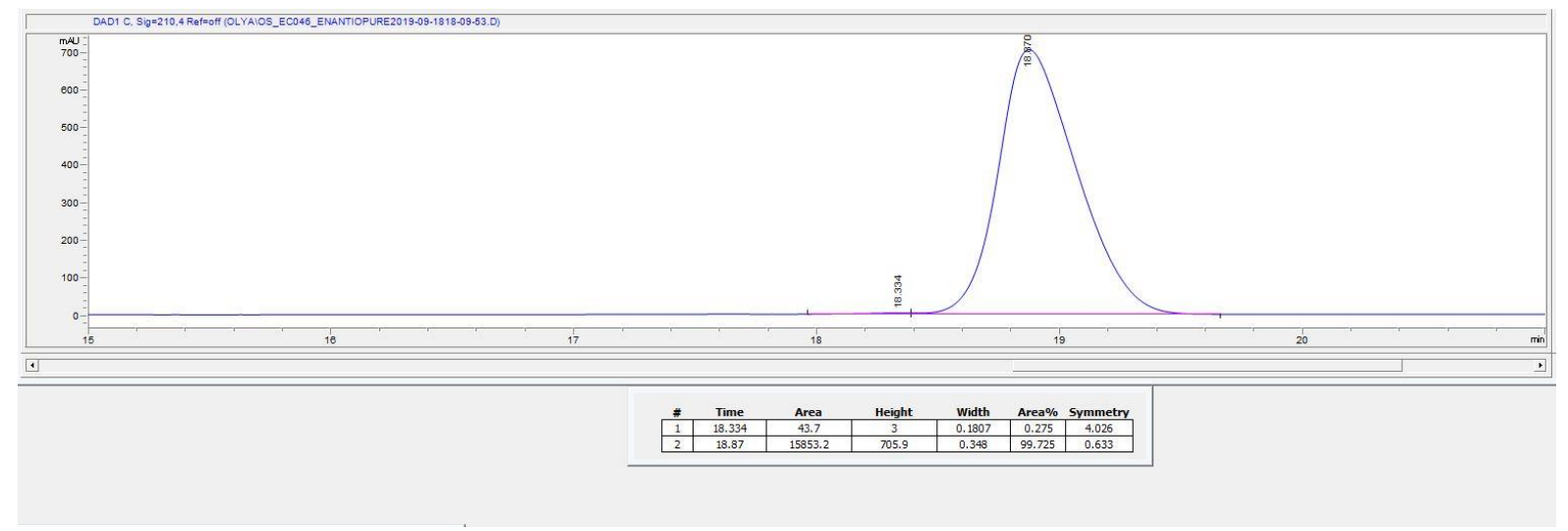

(8S,9aS)-8-Methyl-4,8,9,9a-tetrahydrothieno[3,2-g]indolizin-7(5H)-one and (8S,9aR)-8methyl-4,8,9,9a-tetrahydrothieno[3,2-g]indolizin-7(5H)-one $4 \mathrm{~g}$

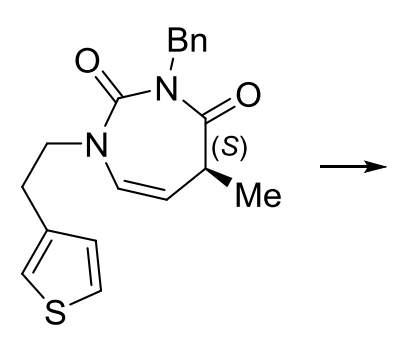

$2 g$, e.r. $>99: 1$

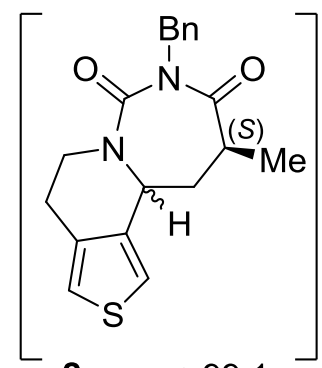

$2 g$, e.r. $>99: 1$

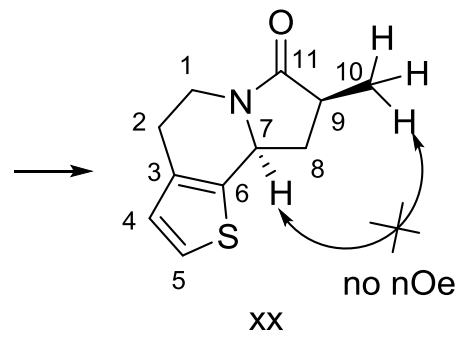

A, e.r. $>99: 1$

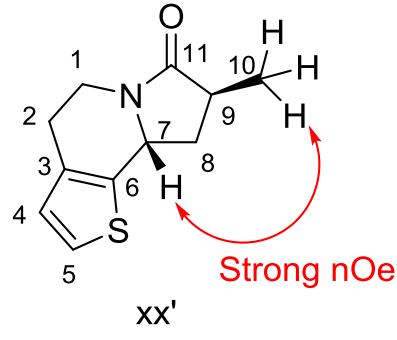

B, e.r. $>99: 1$

$4 g$

To an oven dried reaction tube, fitted with a magnetic stirrer, was charged with $\mathbf{2 g}(50.0 \mathrm{mg}, 0.15$ mmol, e.r. >99:1), TFA $(0.11 \mathrm{~mL}, 1.47 \mathrm{mmol})$ and $\mathrm{CH}_{2} \mathrm{Cl}_{2}(1.50 \mathrm{~mL})$. The tube was fitted with a rubber septum and heated at $60{ }^{\circ} \mathrm{C}$ for 9 hours. The reaction was cooled to room temperature and concentrated in vacuo. The residue was then dissolved in 1,2-DCB $(1.50 \mathrm{~mL})$ and heated at 150 ${ }^{\circ} \mathrm{C}$ for 24 hours. The mixture was cooled to room temperature and concentrated in vacuo. The residue was purified by flash column chromatography (66\% EtOAc/Hexane) to afford the title compound $\mathbf{4 g}(27.5 \mathrm{mg}, 90 \%)$ as a pale brown oil. A mixture of diastereomers A and B were obtained in a 5:1 (A:B) ratio.

Data for the mixture of diastereomers: $v_{\max } / \mathrm{cm}^{-1}: 2928(\mathrm{w}), 1628(\mathrm{~s}), 1452(\mathrm{~m}), 1419(\mathrm{~s}), 1360$ (m), 1299 (m), 865 (m), 723 (m); HRMS: (ESI ${ }^{+}$) calculated for $\mathrm{C}_{11} \mathrm{H}_{14} \mathrm{NOS}$ : 208.0791, found $[\mathrm{M}+\mathrm{H}]^{+}: 208.0789$.

Data for major diastereomer 4g-A: ${ }^{1} \mathrm{H}$ NMR $\left(\mathrm{CDCl}_{3}, 400 \mathrm{MHz}\right): \delta 7.18(\mathrm{~d}, J=5.0 \mathrm{~Hz}, 1 \mathrm{H}, 1 \times$ C5-마), $6.79(\mathrm{~d}, J=5.0 \mathrm{~Hz}, 1 \mathrm{H}, 1 \times \mathrm{C} 4-\underline{\mathrm{H}}), 4.75(\mathrm{dd}, J=9.1,6.6 \mathrm{~Hz}, 1 \mathrm{H}, 1 \times \mathrm{C} 7-\underline{\mathrm{H}}), 4.46-4.35$ (m, $\left.1 \mathrm{H}, 1 \times \mathrm{C} 1-\underline{\mathrm{H}}_{2}\right), 3.02-2.91\left(\mathrm{~m}, 1 \mathrm{H}, 1 \times \mathrm{C} 1-\mathrm{H}_{2}\right), 2.82-2.54\left(\mathrm{~m}, 4 \mathrm{H}, 2 \times \mathrm{C} 2-\underline{\mathrm{H}}_{2}, 1 \times \mathrm{C} 8-\underline{\mathrm{H}}_{2}, 1\right.$ $\times \mathrm{C} 9-\underline{\mathrm{H}}), 1.50\left(\mathrm{ddd}, J=11.4,9.4,9.4 \mathrm{~Hz}, 1 \mathrm{H}, 1 \times \mathrm{C} 8-\mathrm{H}_{2}\right), 1.21\left(\mathrm{~d}, J=6.9 \mathrm{~Hz}, 3 \mathrm{H}, 3 \times \mathrm{C} 10-\underline{\mathrm{H}}_{3}\right)$; ${ }^{13} \mathrm{C} \mathrm{NMR}\left(\mathrm{CDCl}_{3}, 100 \mathrm{MHz}\right): \delta 175.3$ (C11), 136.2 (C6), 133.3 (C3), 127.3 (C4), 123.5 (C5), 53.9 
(C7), 37.8, 37.7 (C8, C9), 37.0 (C1), 25.6 (C2), 15.8 (C10). The relative stereochemistry of this compound was assigned on the basis that there was no nOe observed between $C 7-\underline{H}$ and $C 10-\underline{H}_{3}$.

Data for minor diastereomer 4g-B: Characteristic signals only: ${ }^{1} \mathrm{H} \mathrm{NMR}\left(\mathrm{CDCl}_{3}, 400 \mathrm{MHz}\right): \delta$ $4.88(\mathrm{t}, J=7.3 \mathrm{~Hz}, 1 \mathrm{H}, 1 \times \mathrm{C} 7-\underline{\mathrm{H}}), 2.24-2.11\left(\mathrm{~m}, 1 \mathrm{H}, 1 \times \mathrm{C} 8-\underline{\mathrm{H}}_{2}\right), 1.28(\mathrm{~d}, J=7.3 \mathrm{~Hz}, 3 \mathrm{H}, 3 \times$ $\left.\mathrm{C10}-\underline{\mathrm{H}}_{3}\right)$. The relative stereochemistry of this compound was assigned on the basis that nOe enhancement was observed between $C 7-\underline{H}$ and $C 10-\underline{H}_{3}$.

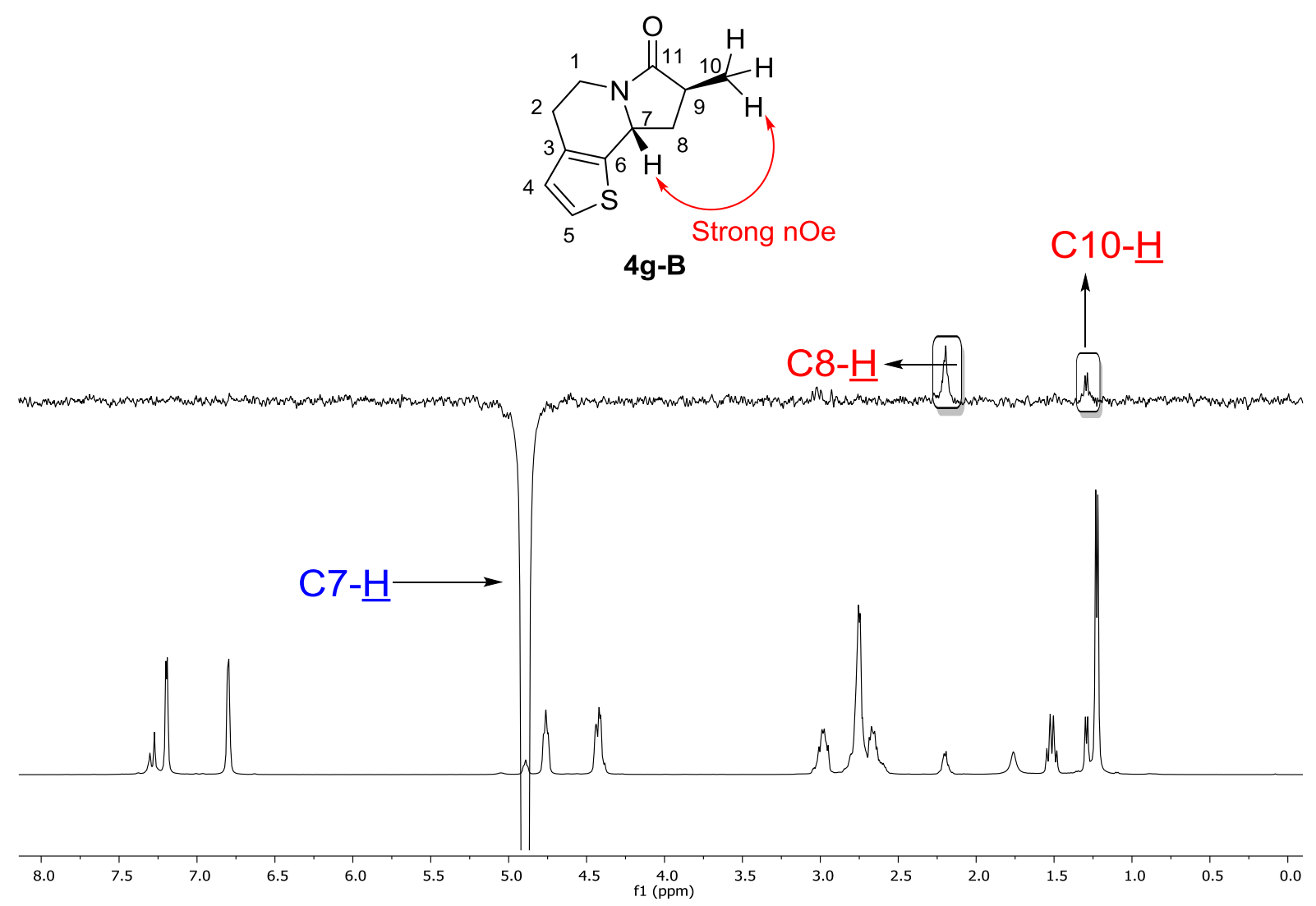




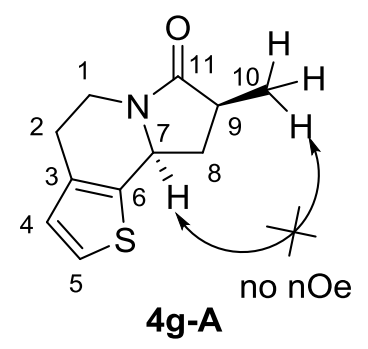

No signal of $\mathrm{C} 10-\underline{H}$

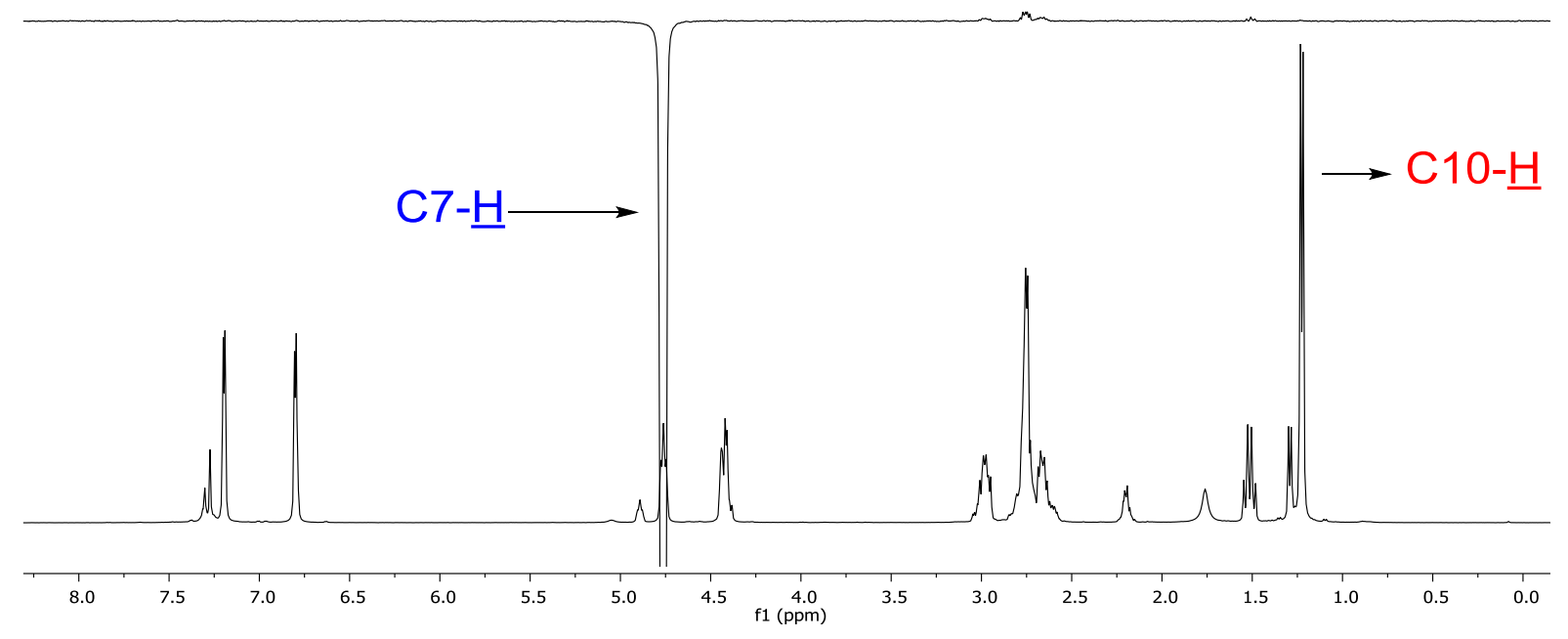

The enantiopurities of these compounds were determined by chiral SFC analysis against a racemic standard (prepared from racemic $\mathbf{2 g}$ by using the same method as above). Chiral SFC conditions: DAICEL CHIRALPAK-IC column (25 cm), $\mathrm{CO}_{2}: \mathrm{MeOH}=92: 8,2.0 \mathrm{~mL} / \mathrm{min}, 140 \mathrm{bar}, 40{ }^{\circ} \mathrm{C}$. Retention times for the major diastereomer - 13.1 minutes (minor), 14.2 minutes (major), e.r. $>99: 1$. Retention times for the minor diastereomer - 12.2 minutes (major), 13.7 mintues (minor), e.r. $>99: 1$.

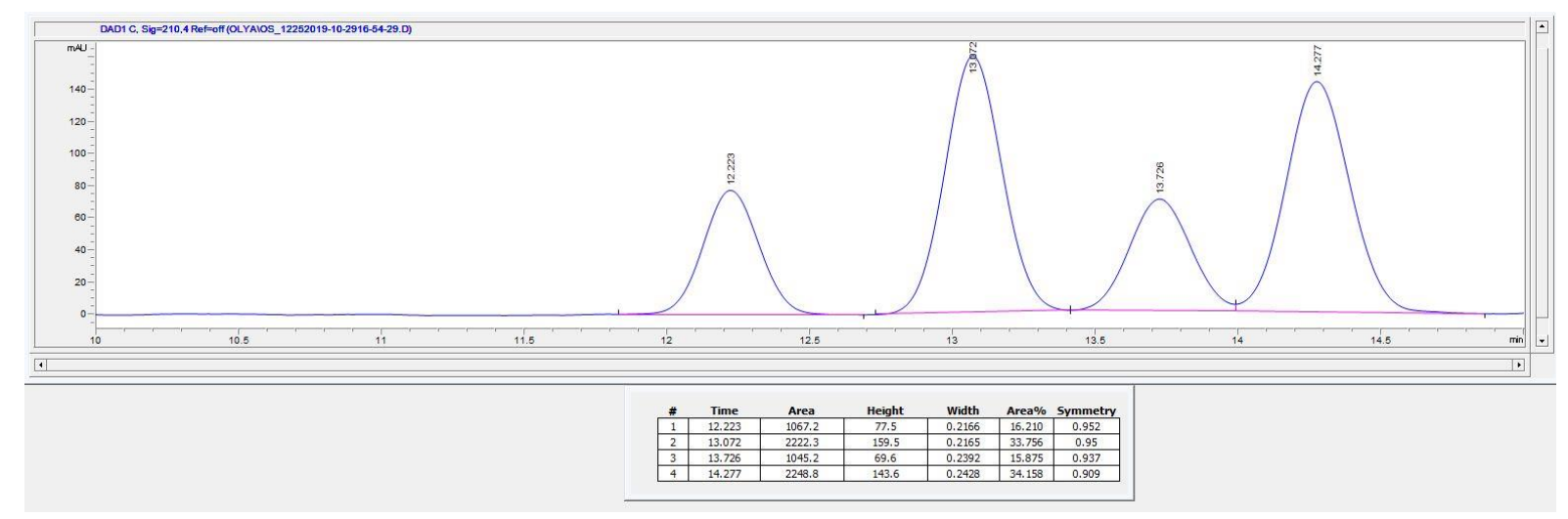




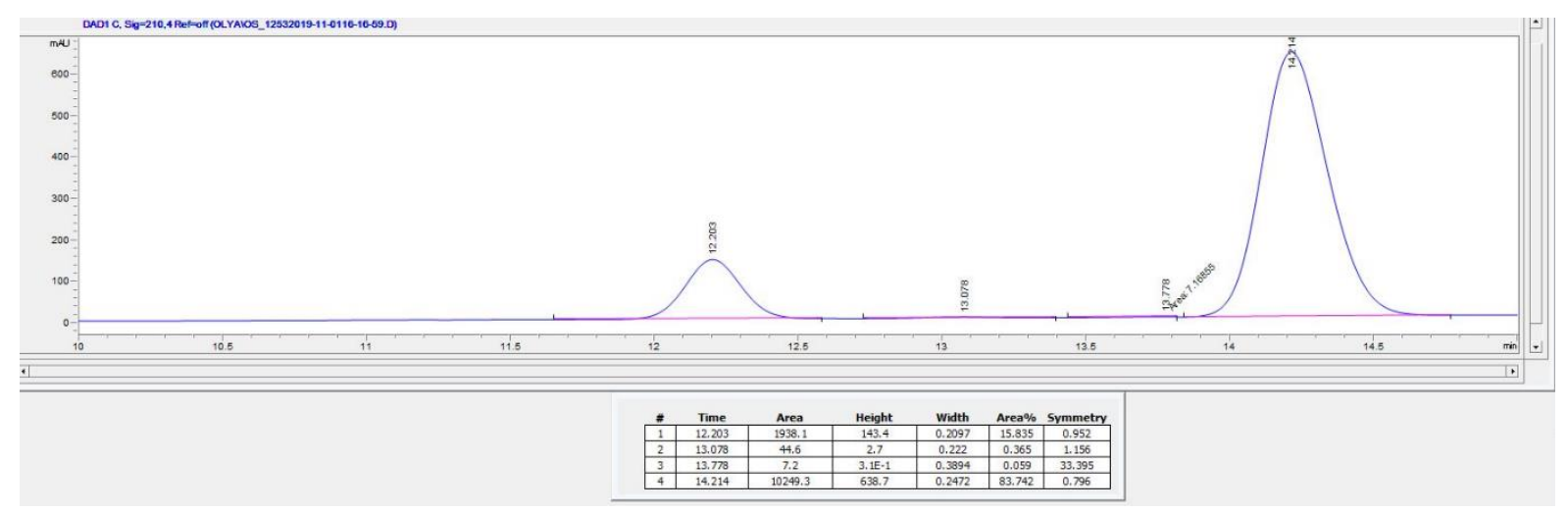

\section{3-Benzyl-1-((1S*,2S*)-2-benzylcyclopropyl)-1-(3,4-dimethoxyphenethyl)urea $1 \mathrm{~h}$}
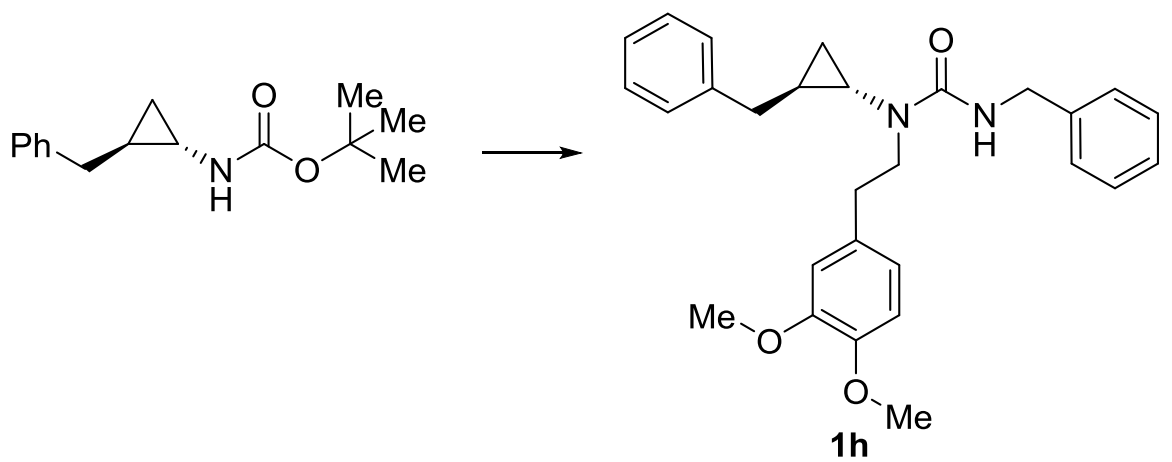

To a solution of the tert-butyl ((1 $\left.S^{*}, 2 S^{*}\right)$-2-benzylcyclopropyl)carbamate (1.20 g, $4.85 \mathrm{mmol}$, $>15: 1$ d.r., prepared according to the literature procedure $\left.{ }^{1}\right)$ in $\mathrm{CH}_{2} \mathrm{Cl}_{2}(5.00 \mathrm{~mL})$ was added trifluoroacetic acid $(3.72 \mathrm{~mL}, 48.5 \mathrm{mmol})$ and the reaction was stirred at room temperature for 3 hours. The reaction mixture was concentrated in vacuo, water $(15 \mathrm{~mL})$ was added and the solution was extracted with $\mathrm{CH}_{2} \mathrm{Cl}_{2}(15.0 \mathrm{~mL})$. The aqueous portion was adjusted to $\mathrm{pH} 12$ by addition of $2 \mathrm{M}$ aq. $\mathrm{NaOH}$ and then extracted with $\mathrm{CH}_{2} \mathrm{Cl}_{2}(3 \times 10 \mathrm{~mL})$. The organic extracts were combined, dried over $\mathrm{MgSO}_{4}$ and concentrated in vacuo. The residue was dissolved in acetonitrile (12.0 mL), $\mathrm{K}_{2} \mathrm{CO}_{3}(1.01 \mathrm{~g}, 7.28 \mathrm{mmol})$ and 3,4-dimethoxyphenethyl-4-methylbenzenesulfonate (1.63 g, 4.85 mmol, prepared according to the literature procedure ${ }^{1}$ ) were added under argon. The tube was sealed and the reaction was heated at $90{ }^{\circ} \mathrm{C}$ for 18 hours. The reaction was cooled to room temperature and concentrated in vacuo. The residue was dissolved in $\mathrm{CH}_{2} \mathrm{Cl}_{2}(20 \mathrm{~mL})$, washed with water $(30 \mathrm{~mL})$, the aqueous portion was further extracted with $\mathrm{CH}_{2} \mathrm{Cl}_{2}(2 \times 20 \mathrm{~mL})$. The organic extracts were combined, dried over $\mathrm{MgSO}_{4}$ and concentrated in vacuo. The residue was dissolved in dry $\mathrm{CH}_{2} \mathrm{Cl}_{2}(10 \mathrm{~mL})$ and cooled down to $0{ }^{\circ} \mathrm{C}$. Triethylamine $(0.60 \mathrm{~mL}, 4.85 \mathrm{mmol})$ and benzyl isocyanate $(0.68 \mathrm{~mL}, 4.85 \mathrm{mmol})$ were added at $0{ }^{\circ} \mathrm{C}$, the reaction mixture was warmed to room temperature and stirred for 18 hours. The solution was diluted with $\mathrm{CH}_{2} \mathrm{Cl}_{2}(10 \mathrm{~mL})$ and washed with water $(20 \mathrm{~mL})$, aq. $1 \mathrm{M} \mathrm{HCl}(20 \mathrm{~mL})$, sat. aq. $\mathrm{NaHCO}_{3}(20 \mathrm{~mL})$ and brine $(20 \mathrm{~mL})$. The organic layer was dried over $\mathrm{MgSO}_{4}$ and concentrated in vacuo. The residue was purified by 
flash column chromatography (30\% EtOAc/Hexane) to afford the title compound $\mathbf{1 h}(0.43 \mathrm{~g}, 20 \%$ over 3 steps) as a colorless oil; $v_{\max } / \mathrm{cm}^{-1}: 3441$ (w), 2933 (w), 1651 (m), 1511 (s), 1453 (m), 1261 (s), 1235 (s), 1028 (s), 699 (s); ${ }^{1} \mathrm{H}$ NMR ( $\left.\mathrm{CDCl}_{3}, 400 \mathrm{MHz}\right): \delta 7.32-7.10$ (m, 10H), 6.77 (d, $J=$ $8.1 \mathrm{~Hz}, 1 \mathrm{H}), 6.69$ (d, $J=1.9 \mathrm{~Hz}, 1 \mathrm{H}), 6.64(\mathrm{dd}, J=8.1,2.0 \mathrm{~Hz}, 1 \mathrm{H}), 5.07$ (br. t, $J=5.9 \mathrm{~Hz}, 1 \mathrm{H})$, $4.14(\mathrm{dd}, J=15.1,6.0 \mathrm{~Hz}, 1 \mathrm{H}), 4.07$ (dd, $J=15.1,6.0 \mathrm{~Hz}, 1 \mathrm{H}), 3.86$ (s, 3H), 3.82 (s, 3H), 3.54 (ddd, $J=13.6,9.0,6.2 \mathrm{~Hz}, 1 \mathrm{H}), 3.35(\mathrm{ddd}, J=13.6,9.0,6.2 \mathrm{~Hz}, 1 \mathrm{H}), 2.93-2.85(\mathrm{~m}, 1 \mathrm{H}), 2.80-$ $2.65(\mathrm{~m}, 2 \mathrm{H}), 2.27-2.23(\mathrm{~m}, 1 \mathrm{H}), 2.16(\mathrm{dd}, J=14.3,9.0 \mathrm{~Hz}, 1 \mathrm{H}), 1.37$ - 1.27 (m, 1H), 0.88 (ddd, $J=9.2,5.1,3.7 \mathrm{~Hz}, 1 \mathrm{H}), 0.77-0.70(\mathrm{~m}, 1 \mathrm{H}) ;{ }^{13} \mathrm{C} \mathrm{NMR}\left(\mathrm{CDCl}_{3}, 100 \mathrm{MHz}\right): \delta 158.5,148.9,147.5$, 140.1, 140.0, 132.5, 129.1, 128.6, 128.5, 127.3, 127.0, 126.9, 120.9 , 112.3, 111.2, 56.0, 56.0, 49.2, 44.3, 38.7, 34.4, 34.4, 24.4, 15.7; HRMS: $\left(\mathrm{ESI}^{+}\right.$) calculated for $\mathrm{C}_{28} \mathrm{H}_{33} \mathrm{~N}_{2} \mathrm{O}_{3}$ : 445.2486, found $[\mathrm{M}+\mathrm{H}]^{+}: 445.2478$.

\section{1,6-Dibenzyl-3-(3,4-dimethoxyphenethyl)-3,6-dihydro-1H-1,3-diazepine-2,7-dione $2 \mathrm{~h}$}
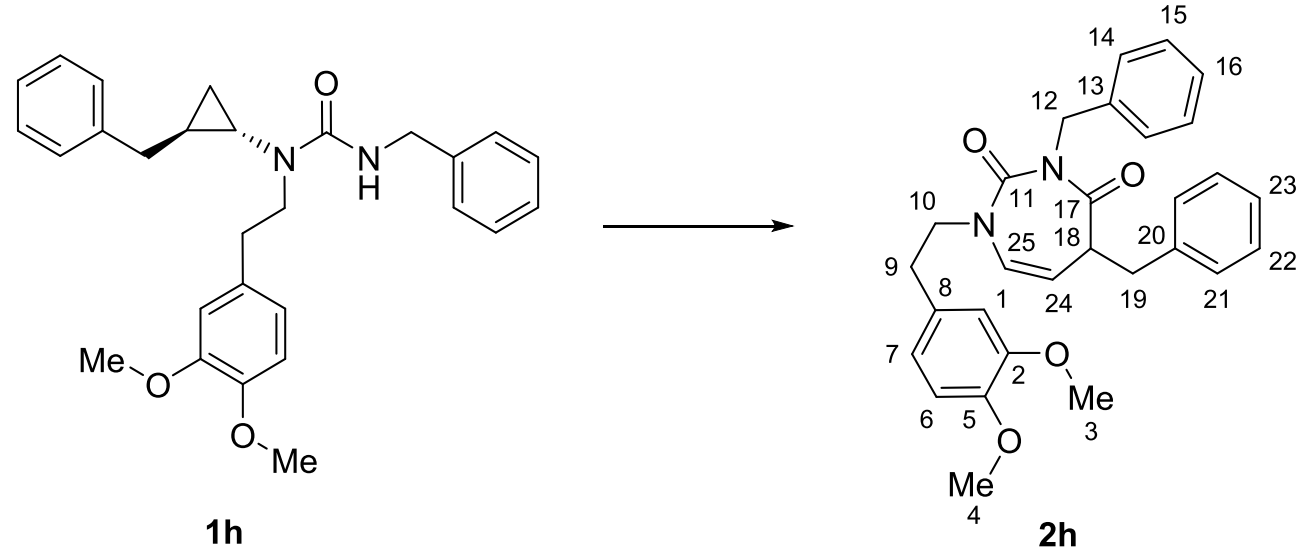

To an oven dried reaction tube, fitted with a magnetic stirrer, was charged with $\mathbf{1 h}$ (66.7 $\mathrm{mg}, 0.15$ mmol), [Rh(cod) $\left.)_{2}\right]$ BARF (13.3 mg, $\left.11.5 \mu \mathrm{mol}\right)$, triphenylphosphine $(5.92 \mathrm{mg}, 22.5 \mu \mathrm{mol})$ and benzoic acid $(2.70 \mathrm{mg}, 22.5 \mu \mathrm{mol})$. The tube was fitted with a rubber septum and purged with argon. Anhydrous 1,2-DCB $(0.75 \mathrm{~mL})$ was added via syringe. The reaction vessel was purged with $\mathrm{CO}$ for 10 minutes and then the solution was sparged with $\mathrm{CO}$ for approximately 20 seconds. The mixture was heated at $100{ }^{\circ} \mathrm{C}$ for 72 hours, under a $\mathrm{CO}$ atmosphere (with $\mathrm{CO}$ balloon attached, 1 atm). The mixture was cooled to room temperature and concentrated in vacuo. The residue was purified by flash column chromatography (30\% EtOAc/Hexane) to afford the title compound $\mathbf{2 h}$ (36.0 mg, 51\%) as a pale yellow oil; $v_{\max } / \mathrm{cm}^{-1}: 2936(\mathrm{w}), 1698(\mathrm{~s}), 1649$ (s), 1515 (s), $1453(\mathrm{~m})$, 1406 (s), 1261 (s), 1237 (s), 1029 (s), 699 (s); ${ }^{1} \mathrm{H}$ NMR ( $\left.\mathrm{CDCl}_{3}, 400 \mathrm{MHz}\right): \delta 7.31-7.11$ (m, 10H, $2 \times \mathrm{C} 14-\underline{\mathrm{H}}, 2 \times \mathrm{C} 15-\underline{\mathrm{H}}, 2 \times \mathrm{C} 21-\underline{\mathrm{H}}, 2 \times \mathrm{C} 22-\underline{\mathrm{H}}, 1 \times \mathrm{C} 16-\underline{\mathrm{H}}, 1 \times \mathrm{C} 23-\underline{\mathrm{H}}), 6.66-6.62(\mathrm{~m}, 2 \mathrm{H}, 1 \times$ C1- $\underline{\mathrm{H}}, 1 \times \mathrm{C6}-\underline{\mathrm{H}}), 6.47(\mathrm{dd}, J=8.1,2.1 \mathrm{~Hz}, 1 \mathrm{H}, 1 \times \mathrm{C} 7-\underline{\mathrm{H}}), 5.78(\mathrm{dd}, J=7.0,1.9 \mathrm{~Hz}, 1 \mathrm{H}, 1 \times \mathrm{C} 25-$ 
$\underline{\mathrm{H}}), 5.20(\mathrm{dd}, J=7.0,6.1 \mathrm{~Hz}, 1 \mathrm{H}, 1 \times \mathrm{C} 24-\underline{\mathrm{H}}), 5.13\left(\mathrm{~d}, J=14.6 \mathrm{~Hz}, 1 \mathrm{H}, 1 \times \mathrm{C12}-\underline{\mathrm{H}}_{2}\right), 4.92(\mathrm{~d}, J=$ $\left.14.6 \mathrm{~Hz}, 1 \mathrm{H}, 1 \times \mathrm{C} 12-\mathrm{H}_{2}\right), 3.93\left(\mathrm{ddd}, J=13.5,7.7 \mathrm{~Hz}, 7.7 \mathrm{~Hz}, 1 \mathrm{H}, 1 \times \mathrm{C} 10-\underline{\mathrm{H}}_{2}\right), 3.82(\mathrm{~s}, 3 \mathrm{H}, 3 \times$ $\mathrm{C} 3-\underline{\mathrm{H}}_{3}$ or $\left.3 \times \mathrm{C} 4-\underline{\mathrm{H}}_{3}\right), 3.80\left(\mathrm{~s}, 3 \mathrm{H}, 3 \times \mathrm{C} 3-\underline{\mathrm{H}}_{3}\right.$ or $\left.3 \times \mathrm{C} 4-\underline{\mathrm{H}}_{3}\right), 3.59(\mathrm{ddd}, J=13.5,7.2,6.1 \mathrm{~Hz}, 1 \mathrm{H}$, $\left.1 \times \mathrm{C} 10-\mathrm{H}_{2}\right), 3.32\left(\mathrm{dd}, J=14.3,6.5 \mathrm{~Hz}, 1 \mathrm{H}, 1 \times \mathrm{C} 19-\underline{\mathrm{H}}_{2}\right), 3.14-3.06(\mathrm{~m}, 1 \mathrm{H}, 1 \times \mathrm{C} 18-\underline{\mathrm{H}}), 2.89$ $\left(\mathrm{dd}, J=14.3,8.3 \mathrm{~Hz}, 1 \mathrm{H}, 1 \times \mathrm{C} 19-\mathrm{H}_{2}\right), 2.78-2.72\left(\mathrm{~m}, 2 \mathrm{H}, 2 \times \mathrm{C} 9-\underline{\mathrm{H}}_{2}\right) ;{ }^{13} \mathrm{C} \mathrm{NMR}\left(\mathrm{CDCl}_{3}, 125\right.$ MHz): $\delta 171.2$ (C17), 153.7 (C11), 149.1, 147.9 (C2, C5), 138.8, 137.9 (C13, C20), 130.5, 129.7, 129.2, 128.7, 128.5, 128.0, 127.3, 126.6 (C8, C14, C15, C16, C21, C22, C23, C25), 121.0 (C7), 118.3 (C24), 111.9, 111.3 (C6, C1), 56.0, 56.0 (C3, C4), 51.5 (C10), 48.4 (C12), 44.9 (C18), 34.3 (C19), 34.0 (C9); HRMS: $\left(\mathrm{ESI}^{+} \text {) calculated for } \mathrm{C}_{29} \mathrm{H}_{30} \mathrm{~N}_{2} \mathrm{NaO}_{4} \text { : 493.2098, found [M+Na] }\right]^{+}$: 493.2083.

$\left(2 S^{*}, 10 \mathrm{~b} S^{*}\right)$-2-Benzyl-8,9-dimethoxy-1,5,6,10b-tetrahydropyrrolo[2,1-a]isoquinolin-3(2H)one and $\left(2 S^{*}, 10 \mathrm{~b} R^{*}\right)-2-B e n z y l-8,9-d i m e t h o x y-1,5,6,10 \mathrm{~b}-$ tetrahydropyrrolo[2,1a]isoquinolin-3(2H)-one $4 \mathrm{~h}$

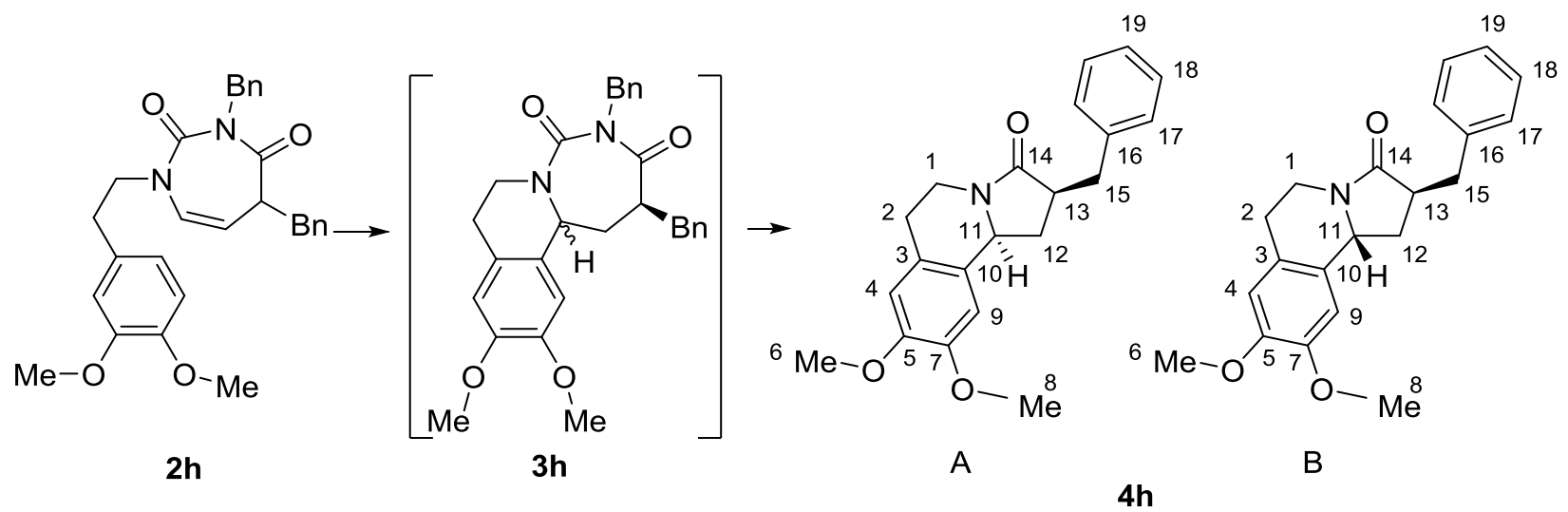

To an oven dried reaction tube, fitted with a magnetic stirrer, was charged with $\mathbf{2 h}(30.0 \mathrm{mg}, 0.06$ mmol) and TFA $(50.0 \mu \mathrm{L}, 0.64 \mathrm{mmol})$ in $\mathrm{CH}_{2} \mathrm{Cl}_{2}(0.60 \mathrm{~mL})$. The tube was fitted with a rubber septum and heated at $60{ }^{\circ} \mathrm{C}$ for 9 hours. The reaction was cooled to room temperature and concentrated in vacuo. The residue was dissolved in 1,2-DCB $(0.60 \mathrm{~mL})$ and heated at $150{ }^{\circ} \mathrm{C}$ for 24 hours. The mixture was cooled to room temperature and concentrated in vacuo. The residue was purified by flash column chromatography (66\% EtOAc/Hexane) to afford the title compound 4h $(12.8 \mathrm{mg}, 59 \%)$ as a pale brown oil. A mixture of diastereomers A and B were obtained in a 5:1 (A:B) ratio.

Data for the mixture of diastereomers: $v_{\max } / \mathrm{cm}^{-1}: 2932$ (w), 1681 (s), 1512 (s), 1453 (s), 1429 (s), 1254 (s), 1227 (s), 1116 (s), 731 (s); HRMS: (ESI ${ }^{+}$) calculated for $\mathrm{C}_{21} \mathrm{H}_{23} \mathrm{NNaO}_{3}$ : 360.1570, found $[\mathrm{M}+\mathrm{Na}]^{+}: 360.1567$. 
Data for major diastereomer $4 \mathbf{h}-\mathrm{A}:{ }^{1} \mathrm{H}$ NMR $\left(\mathrm{CDCl}_{3}, 400 \mathrm{MHz}\right): \delta 7.35-7.15(\mathrm{~m}, 5 \mathrm{H}, 2 \times \mathrm{C17}$ $\underline{\mathrm{H}}, 2 \times \mathrm{C} 18-\underline{\mathrm{H}}, 1 \times \mathrm{C} 19-\underline{\mathrm{H}}), 6.59(\mathrm{~s}, 1 \mathrm{H}, 1 \times \mathrm{C} 9-\underline{\mathrm{H}}), 6.47(\mathrm{~s}, 1 \mathrm{H}, 1 \times \mathrm{C} 4-\underline{\mathrm{H}}), 4.56(\mathrm{dd}, J=9.6,6.4$ $\mathrm{Hz}, 1 \mathrm{H}, 1 \times \mathrm{C11}-\underline{\mathrm{H}}), 4.39-4.25\left(\mathrm{~m}, 1 \mathrm{H}, 1 \times \mathrm{C} 1-\underline{\mathrm{H}}_{2}\right), 3.84$ (s, $\left.3 \mathrm{H}, 3 \times \mathrm{C6}-\underline{\mathrm{H}}_{3}\right), 3.81(\mathrm{~s}, 3 \mathrm{H}, 3 \times \mathrm{C8}-$ $\left.\underline{\mathrm{H}}_{3}\right), 3.43\left(\mathrm{dd}, J=13.9,3.8 \mathrm{~Hz}, 1 \mathrm{H}, 1 \times \mathrm{C} 15-\underline{\mathrm{H}}_{2}\right), 3.06-2.80\left(\mathrm{~m}, 3 \mathrm{H}, 1 \times \mathrm{C} 1-\mathrm{H}_{2}, 1 \times \mathrm{C} 13-\underline{\mathrm{H}}, 1 \times\right.$ $\left.\mathrm{C} 2-\underline{\mathrm{H}}_{2}\right), 2.72-2.53\left(\mathrm{~m}, 2 \mathrm{H}, 1 \times \mathrm{C} 2-\mathrm{H}_{2}, 1 \times \mathrm{C} 12-\underline{\mathrm{H}}_{2}\right), 2.47(\mathrm{dd}, J=13.9,10.8 \mathrm{~Hz}, 1 \mathrm{H}, 1 \times \mathrm{C} 15-$ $\left.\mathrm{H}_{2}\right), 1.48\left(\mathrm{ddd}, J=11.7,9.6,9.6 \mathrm{~Hz}, 1 \mathrm{H}, 1 \times \mathrm{Cl}_{2}-\mathrm{H}_{2}\right) ;{ }^{13} \mathrm{C} \mathrm{NMR}\left(\mathrm{CDCl}_{3}, 100 \mathrm{MHz}\right): \delta 174.0$ (C14), 148.2, 148.0 (C5, C7), 139.9 (C16), 129.1, 128.9, 128.6, 126.4, 125.5 (C3, C10, C17, C18, C19), 111.8 (C9), 107.7 (C4), 56.2, 56.0 (C6, C8), 54.7 (C11), 45.1 (C13), 37.2 (C1), 37.1 (C15), 35.3 (C2), 28.3 (C12). The relative stereochemistry of this compound was assigned by analogy to that of major diastereomer $A$ of $\mathbf{4 g}$.

Data for minor diastereomer 4h-B: Characteristic signals only: ${ }^{1} \mathrm{H} \mathrm{NMR}\left(\mathrm{CDCl}_{3}, 400 \mathrm{MHz}\right): \delta$ $6.56(\mathrm{~s}, 1 \mathrm{H}, 1 \times \mathrm{C} 9-\underline{\mathrm{H}}), 6.44(\mathrm{~s}, 1 \mathrm{H}, 1 \times \mathrm{C} 4-\underline{\mathrm{H}}), 3.82\left(\mathrm{~s}, 3 \mathrm{H}, 3 \times \mathrm{C} 6-\underline{\mathrm{H}}_{3}\right), 3.80\left(\mathrm{~s}, 3 \mathrm{H}, 3 \times \mathrm{C8}-\underline{\mathrm{H}}_{3}\right)$. The relative stereochemistry of this compound was assigned by analogy to that of minor diastereomer B of $\mathbf{4 g}$.

Scheme 3B:

3-Cyclohexyl-1-cyclopropyl-1-((3E,5E)-hepta-3,5-dien-1-yl)urea and 3-cyclohexyl-1cyclopropyl-1-((3Z,5E)-hepta-3,5-dien-1-yl)urea 1i

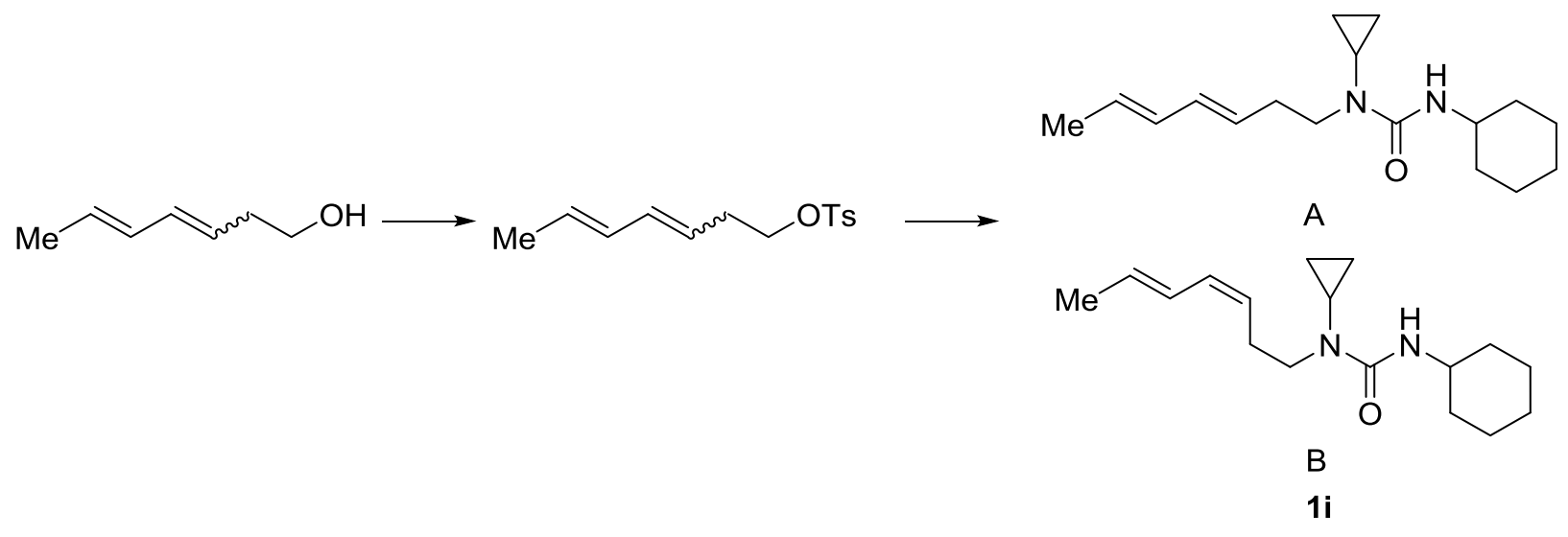

Hepta-3,5-dien-1-ol (mixture of geometric isomers, $(3 E, 5 E):(3 Z, 5 E)=4: 1,1.62 \mathrm{~g}, 14.4 \mathrm{mmol}$, prepared according to the literature procedure $\left.{ }^{7}\right)$ was dissolved in $\mathrm{CH}_{2} \mathrm{Cl}_{2}(30.0 \mathrm{~mL}), \mathrm{Et}_{3} \mathrm{~N}(1.75 \mathrm{~g}$, $17.3 \mathrm{mmol})$, 4-dimethylaminopyridine (351 mg, $2.88 \mathrm{mmol})$ and $\mathrm{TsCl}(3.28 \mathrm{~g}, 17.3 \mathrm{mmol})$ were added at $0{ }^{\circ} \mathrm{C}$ to above solution. The reaction was then warmed to room temperature and stirred for 16 hours. Water $(80 \mathrm{~mL})$ was added and the solution was extracted with $\mathrm{CH}_{2} \mathrm{Cl}_{2}(3 \times 50 \mathrm{~mL})$. The organic extracts were combined, washed with brine $(50 \mathrm{~mL})$, dried over $\mathrm{MgSO}_{4}$ and concentrated in vacuo. The residue was purified by column chromatography to afford the 
corresponding tosylate $(2.23 \mathrm{~g}, 58 \%)$ as a colorless oil. This compound is unstable and was directly used in subsequent reaction without further characterization. In a sealed reaction tube, a solution of cyclopropylamine $(1.04 \mathrm{~mL}, 15.0 \mathrm{mmol})$ and above tosylate product $(1.00 \mathrm{~g}, 3.75 \mathrm{mmol})$ in acetonitrile $(10.0 \mathrm{~mL})$ was heated at $90{ }^{\circ} \mathrm{C}$ for 18 hours. The reaction was cooled to room temperature and trifluoroacetic acid $(0.43 \mathrm{~mL}, 5.63 \mathrm{mmol})$ was added, and the mixture was stirred for 5 minutes before concentrating in vacuo. The residue was dissolved in dry $\mathrm{CH}_{2} \mathrm{Cl}_{2}(50.0 \mathrm{~mL})$ and cooled down to $0{ }^{\circ} \mathrm{C}$. Triethylamine $(1.05 \mathrm{~mL}, 7.50 \mathrm{mmol})$ and cyclohexyl isocyanate $(0.48$ $\mathrm{mL}, 3.75 \mathrm{mmol}$ ) were added. The reaction mixture was then warmed to room temperature and stirred for 18 hours. The solution was washed with water $(20 \mathrm{~mL})$, aq. $1 \mathrm{M} \mathrm{HCl}(20 \mathrm{~mL})$, sat. aq. $\mathrm{NaHCO}_{3}(20 \mathrm{~mL})$ and brine $(20 \mathrm{~mL})$. The organic layer was dried over $\mathrm{MgSO}_{4}$ and concentrated in vacuo. The residue was purified by flash column chromatography (20\% EtOAc/Hexane) to afford the title compound $1 \mathbf{i}(0.62 \mathrm{~g}, 60 \%)$ as a colorless oil. A mixture of geometric isomers A and $\mathrm{B}$ were obtained in a 10:1 (A:B) ratio.

Data for the mixture of geometric isomers: $v_{\max } / \mathrm{cm}^{-1}: 2928(\mathrm{~s}), 2853(\mathrm{~m}), 1644(\mathrm{~s}), 1508(\mathrm{~s}), 1450$ (m), 987 (m); HRMS: $\left(\mathrm{ESI}^{+}\right)$calculated for $\mathrm{C}_{17} \mathrm{H}_{29} \mathrm{~N}_{2} \mathrm{O}$ : 277.2274, found $[\mathrm{M}+\mathrm{H}]^{+}:$277.2270.

Data for major geometric isomer 1i-A: ${ }^{1} \mathrm{H}$ NMR $\left(\mathrm{CDCl}_{3}, 400 \mathrm{MHz}\right): \delta 6.01(\mathrm{ddt}, J=11.4,9.7,6.5$ $\mathrm{Hz}, 2 \mathrm{H}), 5.63-5.47$ (m, 2H), 5.08 (br. d, $J=8.1 \mathrm{~Hz}, 1 \mathrm{H}), 3.71-3.59$ (m, 1H), 3.35 (t, $J=7.2 \mathrm{~Hz}$, $2 \mathrm{H}), 2.48-2.26(\mathrm{~m}, 3 \mathrm{H}), 1.98-1.85(\mathrm{~m}, 2 \mathrm{H}), 1.78-1.65(\mathrm{~m}, 5 \mathrm{H}), 1.62-1.57(\mathrm{~m}, 1 \mathrm{H}), 1.44-$ $1.31(\mathrm{~m}, 2 \mathrm{H}), 1.24-1.06(\mathrm{~m}, 3 \mathrm{H}), 0.84-0.78(\mathrm{~m}, 2 \mathrm{H}), 0.71-0.65(\mathrm{~m}, 2 \mathrm{H}) ;{ }^{13} \mathrm{C} \mathrm{NMR}\left(\mathrm{CDCl}_{3}\right.$, $100 \mathrm{MHz}$ ): $\delta$ 158.2, 132.1, 131.7, 128.9, 127.5, 49.0, 46.7, 34.1, 31.9, 27.6, 25.9, 25.1, 18.1, 8.8. This compound is unstable and was stored as a frozen matrix in benzene.

Data for minor geometric isomer 1i-B: Characteristic signals only: ${ }^{1} \mathrm{H} \mathrm{NMR}\left(\mathrm{CDCl}_{3}, 400 \mathrm{MHz}\right)$ : $\delta 6.43-6.26(\mathrm{~m}), 5.77-5.64(\mathrm{~m}), 5.35-5.23(\mathrm{~m})$.

$\left(3^{1} R^{*}, 5 \mathrm{a} R^{*}, 8 S^{*}, 8 \mathrm{a} S^{*}\right)-8-M e t h y l-3{ }^{1}, 4,5,5 \mathrm{a}, 8,8 \mathrm{a}-h e x a h y d r o p y r r o l o[3,2,1-h i]$ indol-2(1H)-one $4 i$

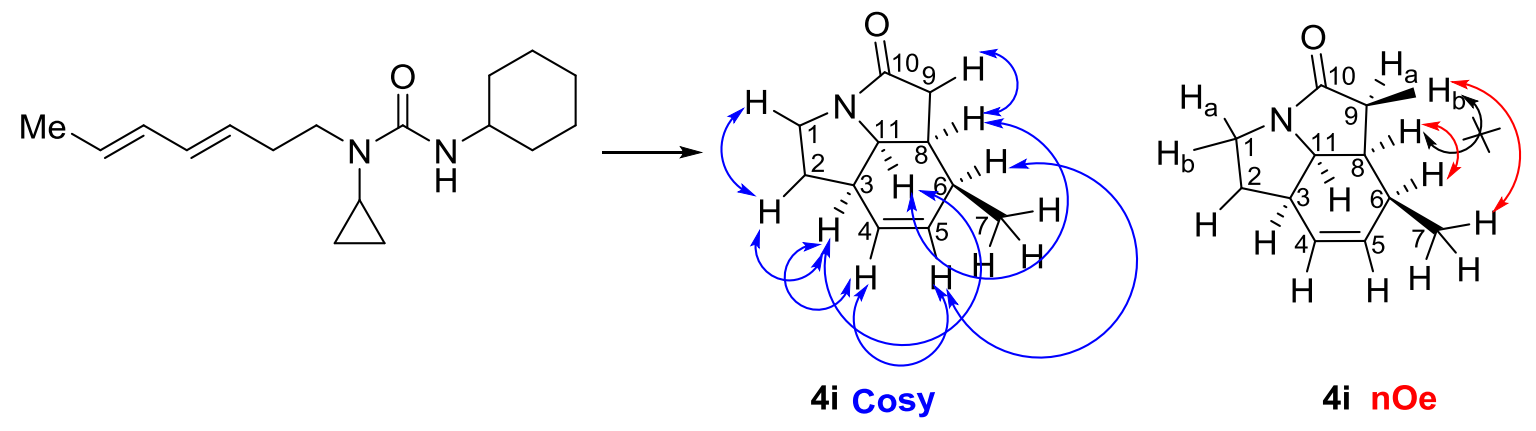


To an oven dried reaction tube, fitted with a magnetic stirrer, was charged with $1 \mathbf{i}(27.6 \mathrm{mg}, 0.10$ mmol, $(3 E, 5 E):(3 Z, 5 E)=10: 1)), \mathrm{P}\left(4-\mathrm{F}-\mathrm{C}_{6} \mathrm{H}_{4}\right)_{3}(4.70 \mathrm{mg}, 15.0 \mu \mathrm{mol}),\left[\mathrm{Rh}(\mathrm{cod})_{2}\right] \mathrm{OTf}(3.50 \mathrm{mg}$, $7.50 \mu \mathrm{mol})$, dimethyl fumarate $(14.4 \mathrm{mg}, 0.10 \mathrm{mmol})$ and BHT $(2.2 \mathrm{mg}, 0.01 \mathrm{mmol})$. The tube was fitted with a rubber septum and purged with argon. Anhydrous benzonitrile $(1.00 \mathrm{~mL})$ was added via syringe. The reaction vessel was purged with $\mathrm{CO}$ for 10 minutes and then the solution was sparged with $\mathrm{CO}$ for approximately 20 seconds. The mixture was heated at $140{ }^{\circ} \mathrm{C}$ for 72 hours, under a $\mathrm{CO}$ atmosphere (with $\mathrm{CO}$ balloon attached, $1 \mathrm{~atm}$ ). The mixture was cooled to room temperature and concentrated in vacuo. The residue was purified by flash column chromatography (20\% Acetonitrile/ $\mathrm{CH}_{2} \mathrm{Cl}_{2}$ ) to afford the title compound $\mathbf{4 i}$ as a single diastereomer $(9.10 \mathrm{mg}, 51 \%$ ) as a pale yellow oil; $v_{\max } / \mathrm{cm}^{-1}: 2957(\mathrm{w}), 2930$ (w), 1683 (s), 1408 (s), 1285 (m), $692(\mathrm{~m}) ;{ }^{1} \mathrm{H}$ $\mathrm{NMR}\left(\mathrm{CDCl}_{3}, 400 \mathrm{MHz}\right): \delta 5.59(\mathrm{ddd}, J=9.7,3.2,3.2 \mathrm{~Hz}, 1 \mathrm{H}, 1 \times \mathrm{C} 4-\underline{\mathrm{H}}), 5.50-5.43(\mathrm{~m}, 1 \mathrm{H}, 1$ $\times \mathrm{C} 5-\underline{\mathrm{H}}), 4.17-4.10(\mathrm{~m}, 1 \mathrm{H}, 1 \times \mathrm{C} 11-\underline{\mathrm{H}}), 3.60\left(\mathrm{ddd}, J=11.7,8.3,8.3 \mathrm{~Hz}, 1 \mathrm{H}, 1 \times \mathrm{C} 1-\underline{\mathrm{H}}_{\mathrm{a}}\right), 3.03-$ $2.93\left(\mathrm{~m}, 1 \mathrm{H}, 1 \times \mathrm{C} 1 \underline{-}_{\mathrm{b}}\right), 2.77-2.67(\mathrm{~m}, 1 \mathrm{H}, 1 \times \mathrm{C} 8-\underline{\mathrm{H}}), 2.57(\mathrm{dd}, J=17.7,10.4 \mathrm{~Hz}, 1 \mathrm{H}, 1 \times \mathrm{C} 9$ $\left.\underline{\mathrm{H}}_{\mathrm{a}}\right), 2.46-2.39(\mathrm{~m}, 1 \mathrm{H}, 1 \times \mathrm{C} 3-\underline{\mathrm{H}}), 2.35-2.24(\mathrm{~m}, 1 \mathrm{H}, 1 \times \mathrm{C6}-\underline{\mathrm{H}}), 2.24-2.14(\mathrm{~m}, 2 \mathrm{H}, 1 \times \mathrm{C} 2-$ $\left.\underline{\mathrm{H}}_{\mathrm{b}}, 1 \times \mathrm{C} 9-\underline{\mathrm{H}}_{\mathrm{b}}\right), 2.02-1.92\left(\mathrm{~m}, 1 \mathrm{H}, 1 \times \mathrm{C} 2-\underline{\mathrm{H}}_{\mathrm{a}}\right), 1.08\left(\mathrm{~d}, J=7.2 \mathrm{~Hz}, 3 \mathrm{H}, 3 \times \mathrm{C} 7-\underline{\mathrm{H}}_{3}\right) ;{ }^{13} \mathrm{C} \mathrm{NMR}$ (CDCl $3,100 \mathrm{MHz}$ ): $\delta 177.3$ (C10), 134.9 (C4), 132.5 (C5), 66.0 (C11), 41.3 (C1), 35.9 (C3), 35.2 (C9), 33.6 (C8), 32.7 (C2), 30.7 (C6), 17.6 (C7); HRMS: (ESI ${ }^{+}$) calculated for $\mathrm{C}_{11} \mathrm{H}_{16} \mathrm{NO}$ : 178.1226, found $[\mathrm{M}+\mathrm{H}]^{+}: 178.1224$.

The structure of this compound was corroborated by HH Cosy experiments (as indicated on the compound structure, the Cosy spectrum was obtained with minor impurity). HH Cosy correlations were observed between C1- $\underline{H}$ and $C 2-\underline{H}, C 2-\underline{H}$ and $C 3-\underline{H}, C 3-\underline{H}$ and $C 4-\underline{H}, C 4-\underline{H}$ and $C 5-\underline{H}, C 5-$ $\underline{H}$ and C6- $\underline{H}, C 6-\underline{H}$ and C7- $\underline{H}, C 8-\underline{H}$ and C9- $\underline{H}, C 8-\underline{H}$ and C11- $\underline{H}, C 3-\underline{H}$ and C11- $\underline{H}$. 


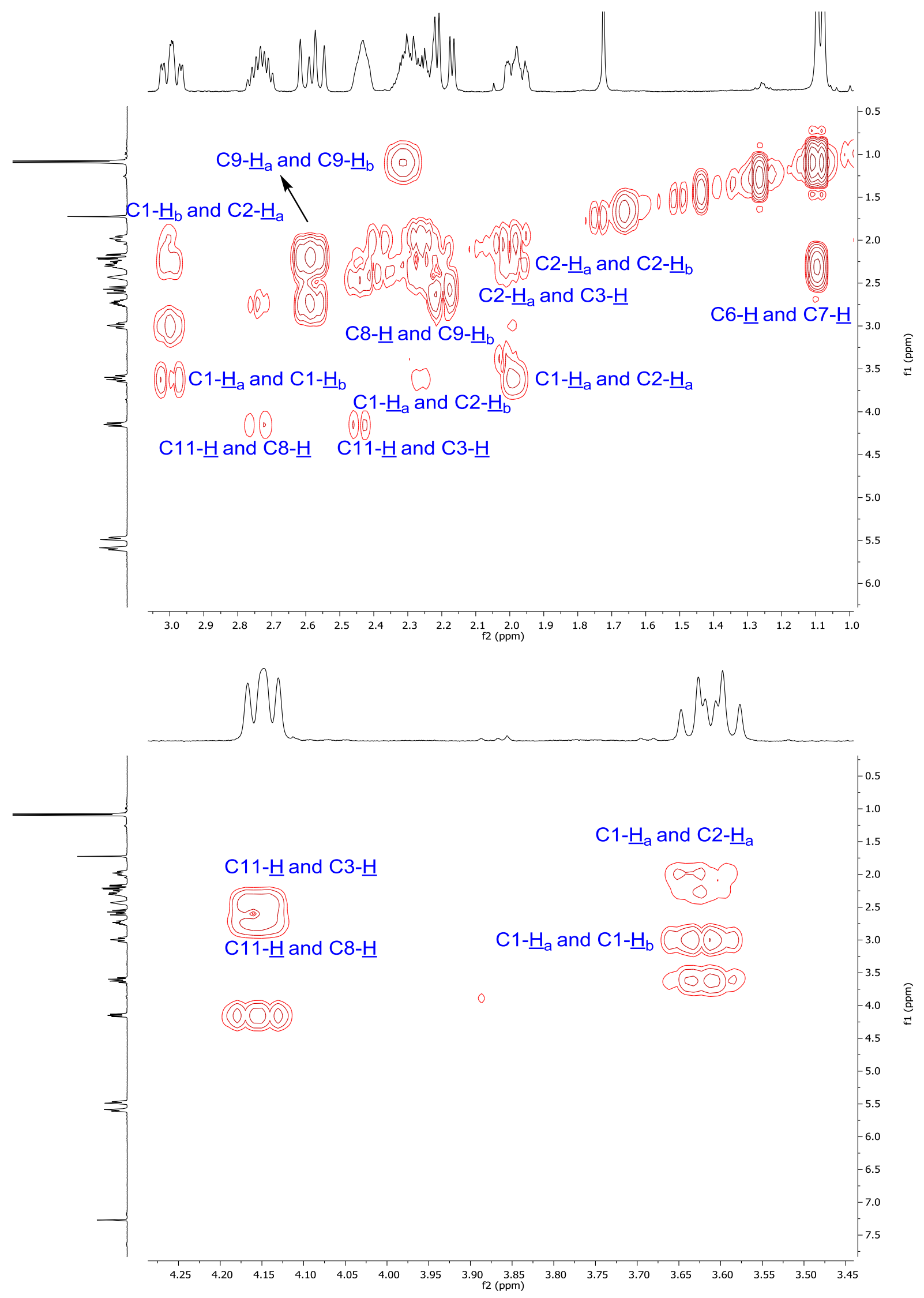




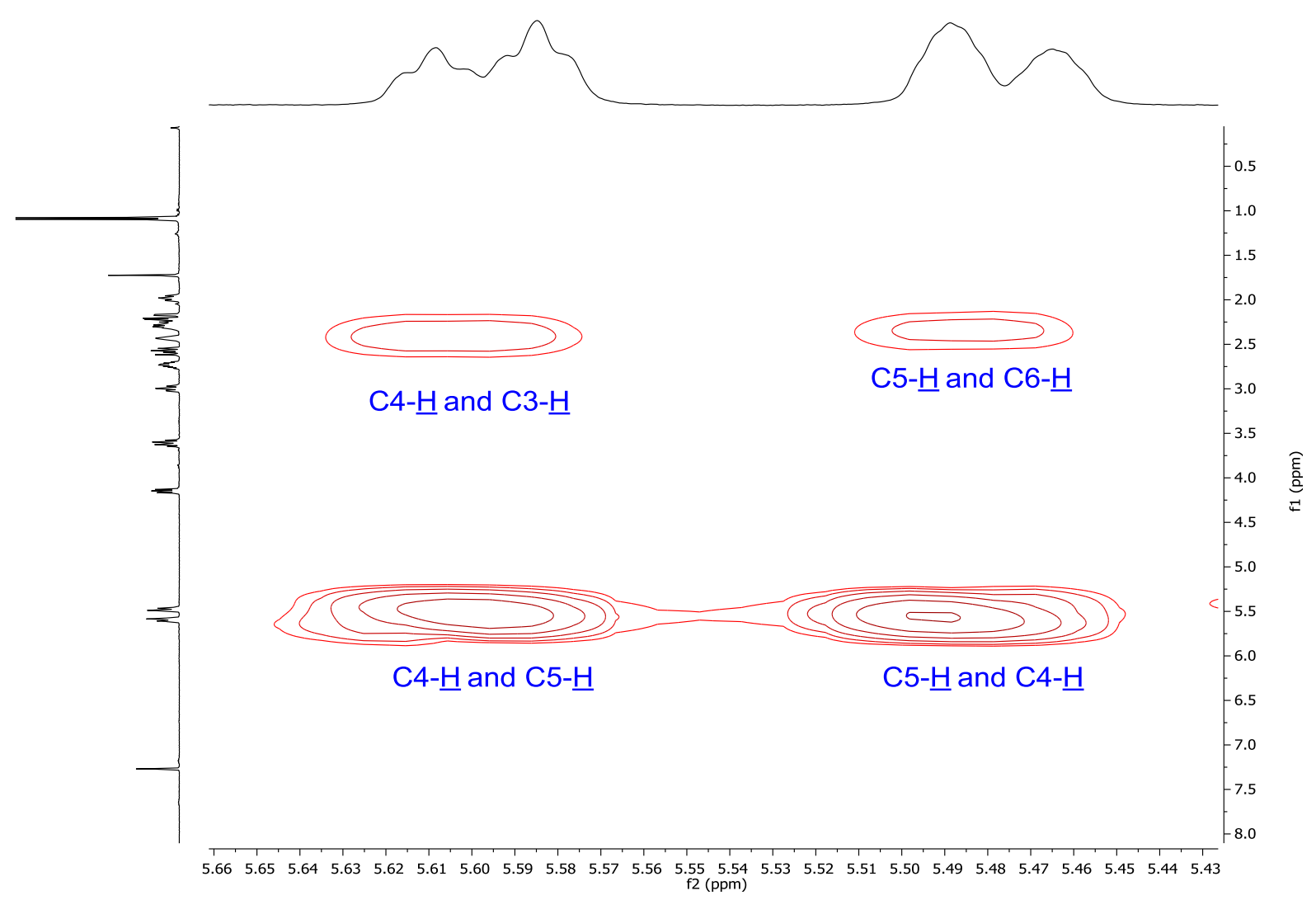

The relative stereochemistry of $\mathrm{C11}-\underline{H}, \mathrm{C8}-\underline{\mathrm{H}}$ and $\mathrm{C3}-\underline{\mathrm{H}}$ of $\mathbf{4 i}$ was corroborated by using quantifiable nOe analysis. In quantifiable nOe analysis, the determination of the interproton distances is based on the comparison of relative nOe intensities instead of absolute intensities. The advantage of this method is the minimisation of the perturbations that affect all of the spins. The relative stereochemistry of $\mathrm{C8}-\underline{H}$ and $\mathrm{C6}-\underline{H}$ of $\mathbf{4 i}$ was corroborated by nOe experiments (as indicated on the compound structure). nOe enhancements were observed between $C 7-\underline{H}_{3}$ and C9$\underline{H}_{b}, C 8-\underline{H}$ and C6- $\underline{H}$, at the same time, there is no nOe was observed between $C \mathbf{9}-\underline{H}_{b}$ and C8- $\underline{H}$.

\section{Quantifiable nOe analysis}

1-Dimensional transient nOe spectra were acquired on a $500 \mathrm{MHz}$ Bruker Avance IIIHD NMR spectrometer equipped with a $\mathrm{DCH}{ }^{13} \mathrm{C}$-optimized cryoprobe. They used a Chemical-shiftselective filter nOe pulse sequence ('selcssfnozs') from the Bruker Top Spin library with a 500ms nOe mixing time and otherwise using the same spectrum parameters as for ${ }^{1} \mathrm{H}$ spectra.

nOe-distance Analysis: nOe-distance analysis on 4i confirmed the relative stereochemistry of C3$\underline{\mathrm{H}}, \mathrm{C} 8-\underline{\mathrm{H}}$ and $\mathrm{C} 11-\underline{\mathrm{H}}$ using the relationship between nOe intensity and internuclear distance in transient nOe experiments. The underpinning method used is based on that described by Butts et $a l^{8}$ which assumes that all interproton distances between nuclei X and $\mathrm{Y}\left(\mathrm{r}_{\mathrm{XY}}\right)$ are related to the intensity of the nOe signal between them ( $\left.\eta_{\mathrm{XY}}\right)$ by the relationship: $\eta_{\mathrm{XY}} \alpha \mathrm{r}_{\mathrm{XY}}{ }^{-6}$, and that the effects 
of differential relaxation between all nuclei in the molecule can be corrected for by measuring nOe integrals relative to the intensity of the irradiated peak-the so-called PANIC method. ${ }^{9}$

In this case the PANIC-corrected nOe intensities from irradiation of $\mathrm{C} 11-\underline{\mathrm{H}}$ to $\mathrm{C} 3-\underline{\mathrm{H}}$ and $\mathrm{C} 8-\underline{\mathrm{H}}$, gave rise to almost identical internuclear distances, which were established to be $\sim 2.3 \AA$ after calibration against the known nOe-distance for $\mathrm{C} 1-\underline{\mathrm{H}}_{\mathrm{a}}-\mathrm{C} 1-\underline{\mathrm{H}}_{\mathrm{b}}(\sim 1.83 \AA \AA \AA)$. Molecular mechanics modelling on 4i found a single low energy conformer with $\mathrm{C} 11-\underline{\mathrm{H}}-\mathrm{C} 3-\underline{\mathrm{H}}$ and $\mathrm{C} 11-\underline{\mathrm{H}}-\mathrm{C} 8-\underline{\mathrm{H}}$ distances of $2.53 \AA$ and $2.34 \AA$ respectively, which are within the expected error limits of nOedistance analysis (For comparison, an nOe-distance of $>3 \AA$ would have been expected for $\mathrm{C} 3-\underline{H}$ or $\mathrm{C} 8-\underline{\mathrm{H}}$ in alternative diastereomers (trans relationship)). Other measurable nOe-distances were also found to fit with the proposed structure, however the absolute intensities of the nOes in the datasets for compound $\mathbf{4} \mathbf{i}$ were very weak and so we do not rely on these here.

nOe integrals and nOe-distance analysis for $4 \mathrm{i}$

\begin{tabular}{|c|c|c|c|c|c|c|}
\hline $\begin{array}{l}\text { nOe } \\
\text { from }\end{array}$ & $\begin{array}{c}\text { nOe } \\
\text { to }\end{array}$ & Integral & $\begin{array}{l}\text { Relative } \\
\text { distance }\end{array}$ & $\begin{array}{c}\text { nOe- } \\
\text { Distance } \\
/ \AA\end{array}$ & $\underset{\text { Model Distance }}{\text { /A }}$ & Error \\
\hline C11-프 & C3- $\underline{H}$ & 4.77 & 1.259 & 2.30 & 2.53 & $8.92 \%$ \\
\hline C11- $\underline{\bar{H}}$ & $\mathrm{C} 8-\overline{\mathrm{H}}$ & 4.88 & 1.254 & 2.30 & 2.34 & $1.90 \%$ \\
\hline C1- $\overline{\mathbf{H a}^{\mathbf{a}}}$ & $\mathrm{C} 1-\overline{\mathrm{H}}_{\mathrm{b}}$ & 19.01 & 1.000 & 1.83 & 1.83 & $0.00 \%$ \\
\hline
\end{tabular}

${ }^{\mathrm{a}} \mathrm{C} 1-\underline{\mathrm{H}}_{\mathrm{a}} \mathrm{C} 1-\underline{\mathrm{H}}_{\mathrm{b}}$ (methylene) was used as the reference distance, with measured $\mathrm{C} 11-\underline{\mathrm{H}}$ nOedistances established relative to this. See reference 8 for details.

1-Dimensional transient nOe spectrum of C11- $\underline{\mathrm{H}}$ of compound 4i with PANIC-corrected integrals for $\mathrm{C} 3-\underline{\mathrm{H}}$ and $\mathrm{C} 8-\underline{\mathrm{H}}$ highlighted.

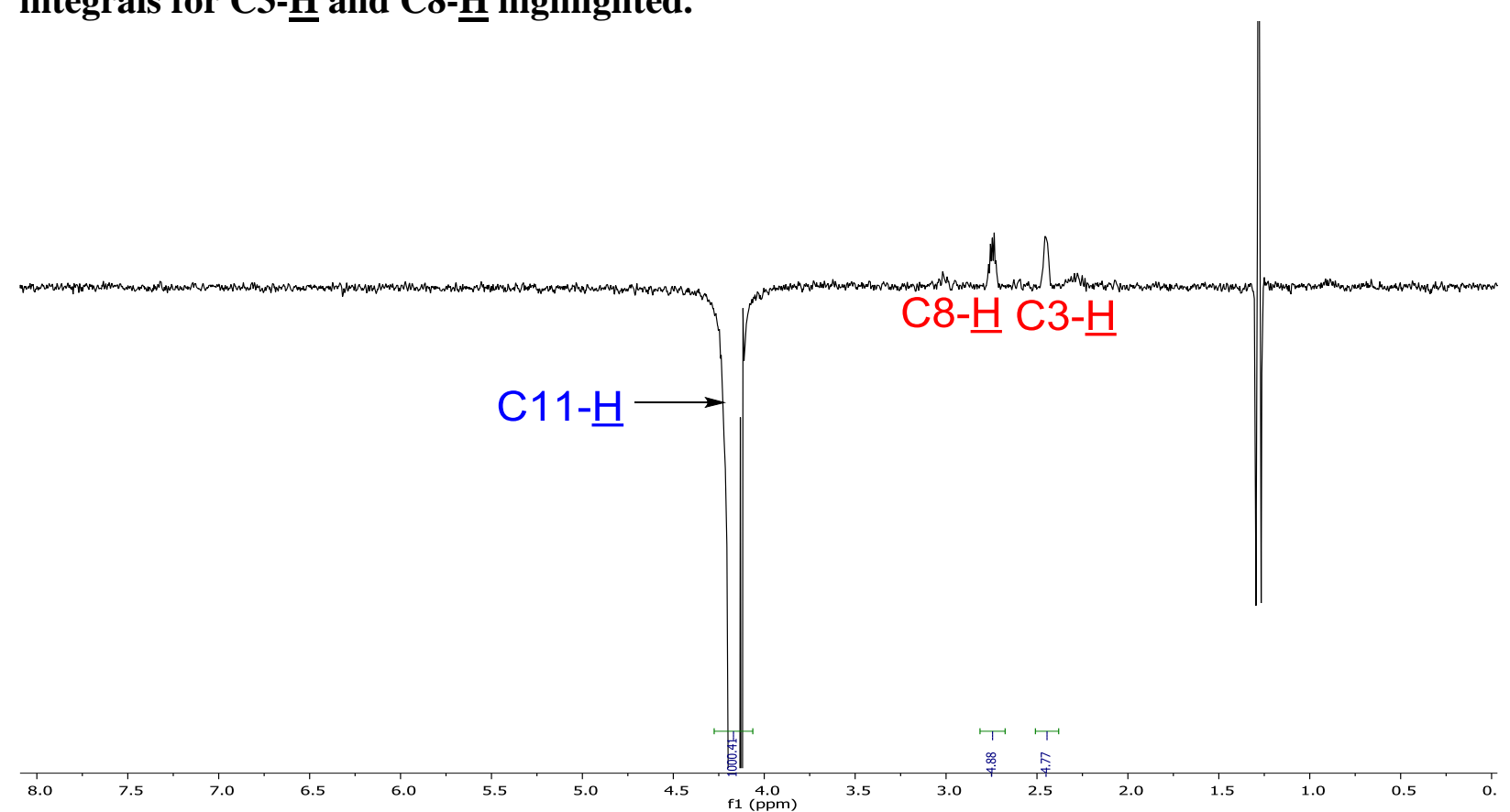


1-Dimensional transient nOe spectrum of $\mathrm{C} 1-\underline{H}_{a}$ of compound 4i with PANIC-corrected integrals for $\mathrm{C} 1-\underline{H}_{b}$ and $\mathrm{C} 2-\underline{H}_{a}$ highlighted.

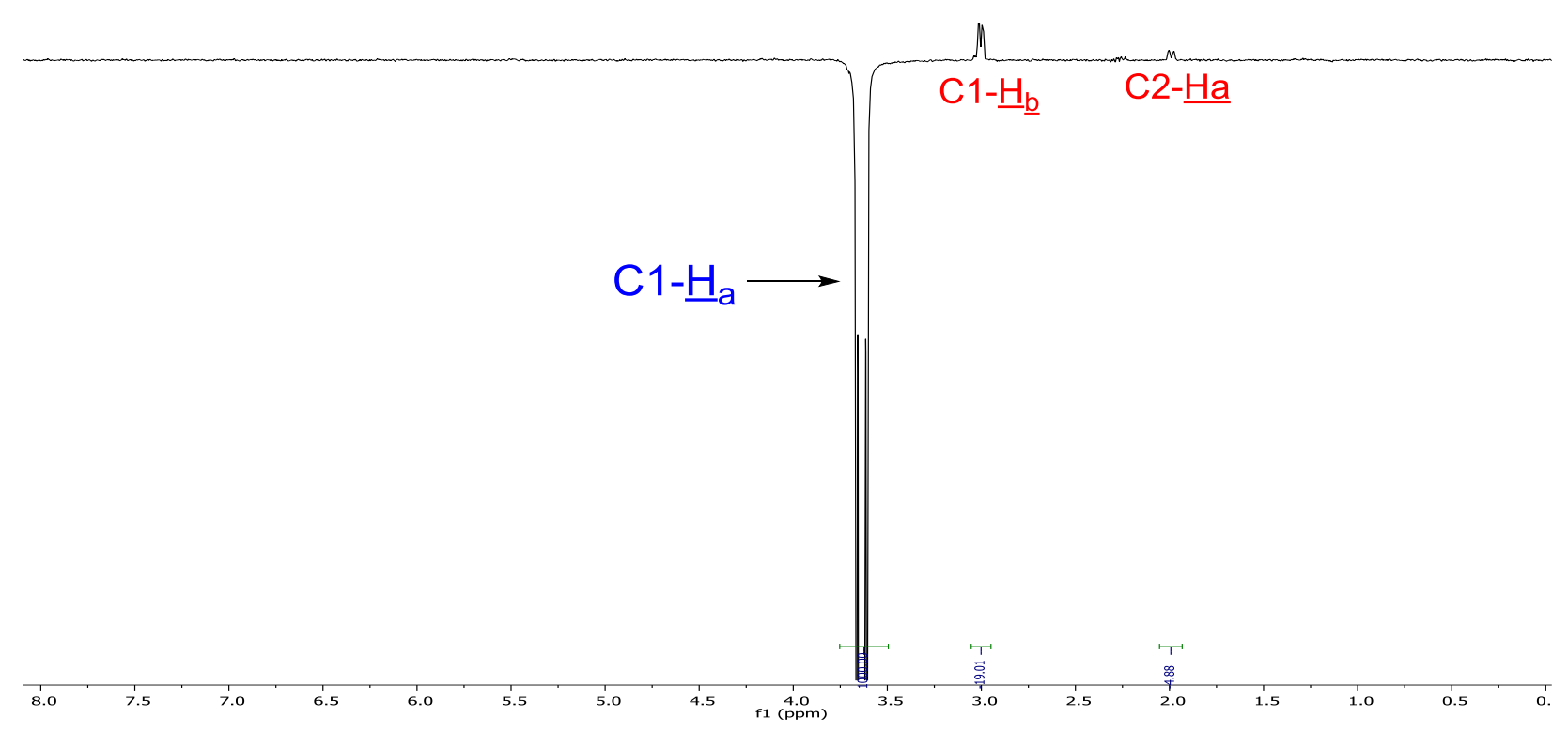

nOe evidence for C6- $\underline{\mathrm{H}}$ and $\mathrm{C} 8-\underline{\mathrm{H}}$
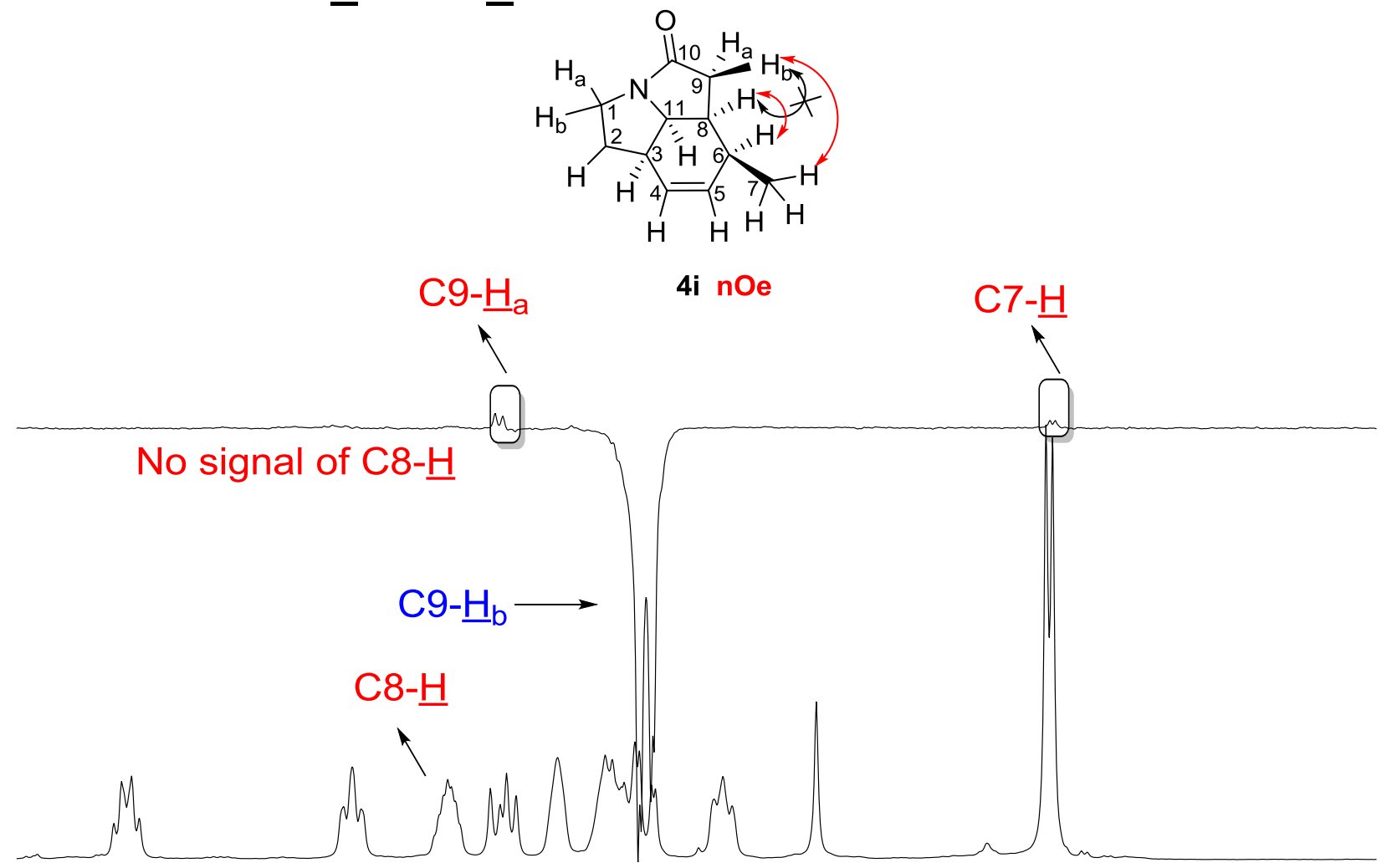

\begin{tabular}{llllllllllllllllllllllllllllllllllllllllllllllllll}
\hline .9 & 3.8 & 3.7 & 3.6 & 3.5 & 3.4 & 3.3 & 3.2 & 3.1 & 3.0 & 2.9 & 2.8 & 2.7 & 2.6 & 2.5 & 2.4 & 2.3 & 2.2 & 2.1 & 2.0 & 1.9 & 1.8 & 1.7 & 1.6 & 1.5 & 1.4 & 1.3 & 1.2 & 1.1 & 1.0 & 0.9 & 0.8 & 0.7 & 0.6 & 0.5 & 0.4 & 0.3 & 0.
\end{tabular} 


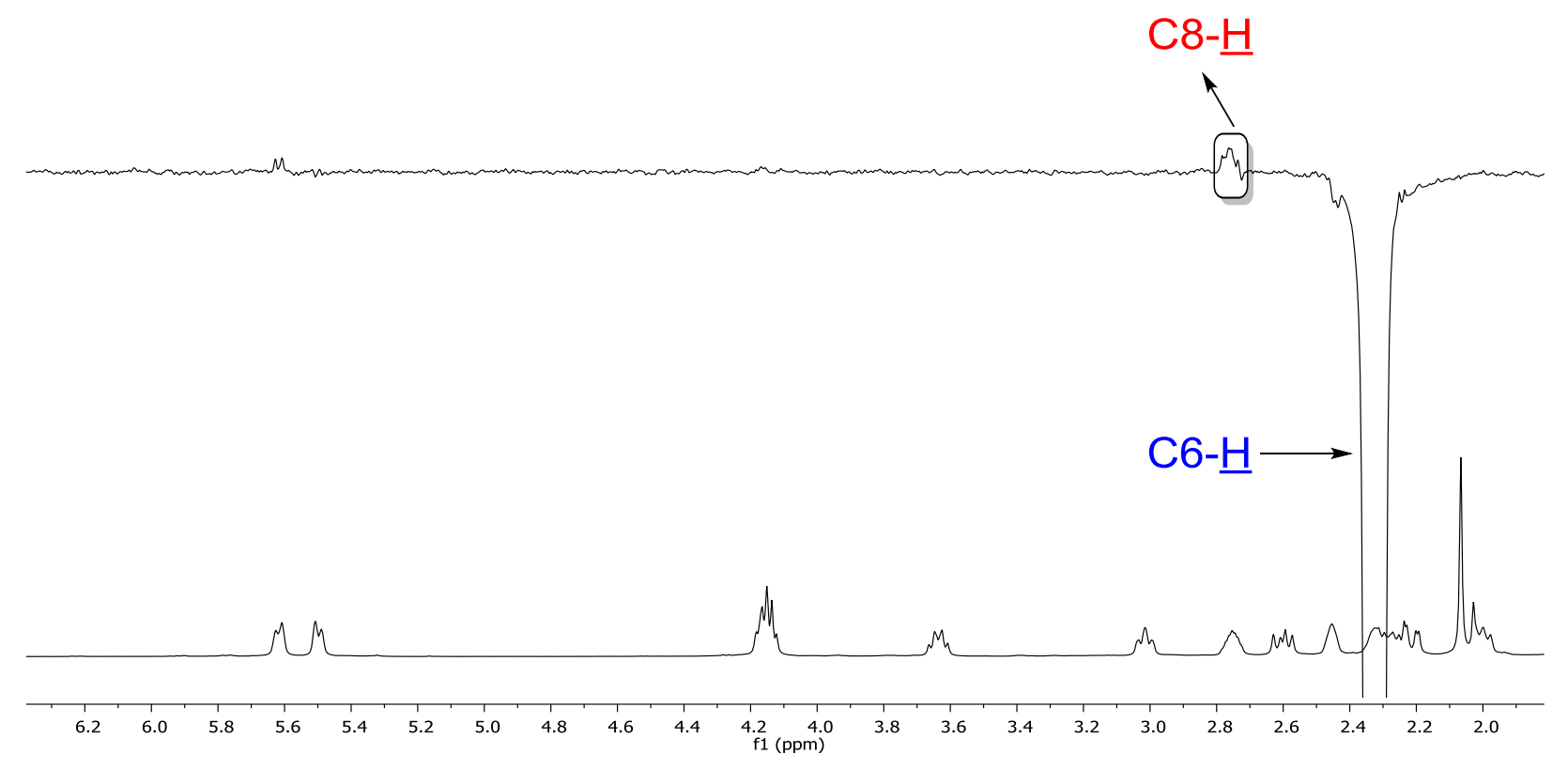

(3E,5E)-6-(4-Fluorophenyl)hexa-3,5-dien-1-ol and (3Z,5E)-6-(4-Fluorophenyl)hexa-3,5dien-1-ol

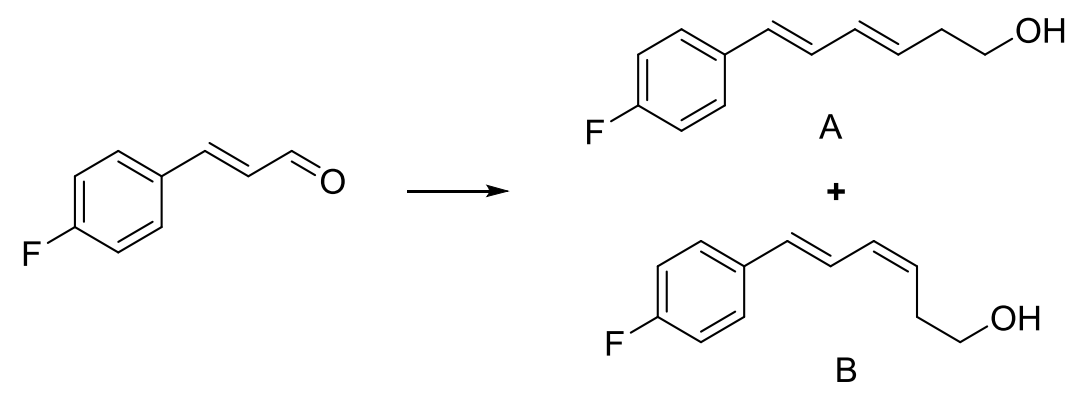

A suspension of (3-hydroxypropyl)triphenylphosphonium bromide (4.82 g, $12.0 \mathrm{mmol}$, prepared according to the literature procedure $\left.{ }^{10}\right)$ in dry THF $(25.0 \mathrm{~mL})$ was cooled to $0^{\circ} \mathrm{C}, n$-BuLi $(16.7$ $\mathrm{mL}, 1.44 \mathrm{M}$ in hexane) was then added dropwise over 5 minutes. The solution was stirred at $0{ }^{\circ} \mathrm{C}$ for 30 minutes and (E)-3-(4-fluorophenyl)acrylaldehyde $(1.80 \mathrm{~g}, 12.0 \mathrm{mmol}$, prepared according to the literature procedure $\left.{ }^{11}\right)$ in dry THF $(8.00 \mathrm{~mL})$ was added dropwise over 5 minutes, the solution was stirred at $0{ }^{\circ} \mathrm{C}$ for 2.5 hours. The reaction was diluted with $\mathrm{Et}_{2} \mathrm{O}(30 \mathrm{~mL})$ and washed with sat. aq. $\mathrm{NH}_{4} \mathrm{Cl}(30 \mathrm{~mL})$ and brine $(30 \mathrm{~mL})$. The organic layer was dried over $\mathrm{MgSO}_{4}$ and concentrated in vacuo. The residue was purified by flash column chromatography (20-40\% EtOAc/Hexane) to afford the title compound $(1.13 \mathrm{~g}, 49 \%)$ as a colorless oil; A mixture of geometric isomers $\mathrm{A}$ and $\mathrm{B}$ were obtained in a 4:1 (A:B) ratio. 
Data for the mixture of geometric isomers: $v_{\max } / \mathrm{cm}^{-1}: 3270$ (br. m), 2945 (m), 1508 (s), 1248 (s), 1050 (s), 982 (s), 834 (m); HRMS: $\left(\mathrm{ESI}^{+} \text {) calculated for } \mathrm{C}_{12} \mathrm{H}_{13} \mathrm{FO} \text { : 193.1023, found [M+H] }\right]^{+}$: 193.1019.

Data for major geometric isomer A: ${ }^{1} \mathrm{H} \mathrm{NMR}\left(\mathrm{CDCl}_{3}, 400 \mathrm{MHz}\right): \delta 7.37-7.31(\mathrm{~m}, 2 \mathrm{H}), 7.04-$ $6.95(\mathrm{~m}, 2 \mathrm{H}), 6.67(\mathrm{dd}, J=15.7,10.4 \mathrm{~Hz}, 1 \mathrm{H}), 6.45(\mathrm{~d}, J=15.7 \mathrm{~Hz}, 1 \mathrm{H}), 6.30$ (dd, $J=15.3,10.4$ $\mathrm{Hz}, 1 \mathrm{H}), 5.79(\mathrm{dt}, J=15.3,7.2 \mathrm{~Hz}, 1 \mathrm{H}), 3.77-3.69(\mathrm{~m}, 2 \mathrm{H}), 2.46-2.39(\mathrm{~m}, 2 \mathrm{H}), 1.41-1.37(\mathrm{~m}$, $1 \mathrm{H}) ;{ }^{13} \mathrm{C} \mathrm{NMR}\left(\mathrm{CDCl}_{3}, 125 \mathrm{MHz}\right): \delta 162.3(\mathrm{~d}, J=246.8 \mathrm{~Hz}), 133.7(\mathrm{~d}, J=3.2 \mathrm{~Hz}), 133.4,130.9$, 130.1, $128.7(\mathrm{~d}, J=2.4 \mathrm{~Hz}), 127.8(\mathrm{~d}, J=7.9 \mathrm{~Hz}), 115.68(\mathrm{~d}, J=21.7 \mathrm{~Hz}), 62.1,36.4 ;{ }^{19} \mathrm{~F} \mathrm{NMR}$ $\left(\mathrm{CDCl}_{3}, 376 \mathrm{MHz}\right):-114.48(\mathrm{td}, J=8.8,4.5 \mathrm{~Hz})$.

Data for minor geometric isomer B: Characteristic signals only: $\delta 6.52(\mathrm{~d}, J=15.6 \mathrm{~Hz}, 1 \mathrm{H}), 5.63$ $-5.48(\mathrm{~m}, 1 \mathrm{H}), 2.56(\mathrm{td}, J=6.9,5.4 \mathrm{~Hz}, 1 \mathrm{H}) .{ }^{19} \mathrm{~F} \mathrm{NMR}\left(\mathrm{CDCl}_{3}, 376 \mathrm{MHz}\right):-114.10(\mathrm{td}, J=8.8$, $4.5 \mathrm{~Hz})$

\section{3-Cyclohexyl-1-cyclopropyl-1-((3E,5E)-6-(4-fluorophenyl)hexa-3,5-dien-1-yl)urea 1j}

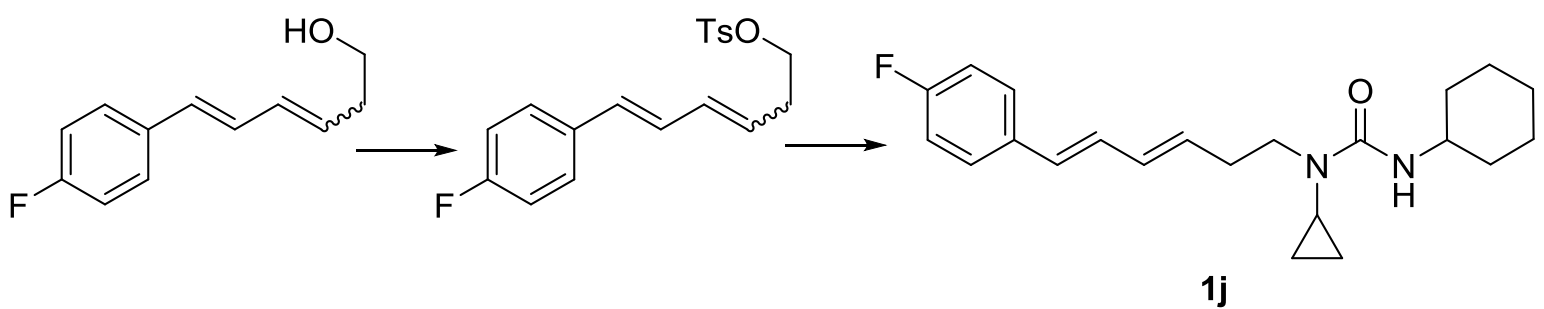

6-(4-Fluorophenyl)hexa-3,5-dien-1-ol (mixture of geometric isomers $(3 E, 5 E):(3 Z, 5 E)=4: 1,1.13$ $\mathrm{g}, 5.88 \mathrm{mmol})$ was dissolved in $\mathrm{CH}_{2} \mathrm{Cl}_{2}(15.0 \mathrm{~mL}), \mathrm{Et}_{3} \mathrm{~N}$ (0.72g, $\left.7.06 \mathrm{mmol}\right)$, 4dimethylaminopyridine $(143 \mathrm{mg}, 1.18 \mathrm{mmol})$ and $\mathrm{TsCl}(1.34 \mathrm{~g}, 7.06 \mathrm{mmol})$ were added at $0{ }^{\circ} \mathrm{C}$. The reaction was then warmed to room temperature and stirred for 16 hours. Water $(40 \mathrm{~mL})$ was added and the solution was extracted with $\mathrm{CH}_{2} \mathrm{Cl}_{2}(3 \times 30 \mathrm{~mL})$. The organic extracts were combined, washed with brine $(30 \mathrm{~mL})$, dried over $\mathrm{MgSO}_{4}$ and concentrated in vacuo. The residue was purified by flash column chromatography (100\% toluene) to afford the corresponding tosylate $(1.10 \mathrm{~g}, 54 \%)$ as a colorless oil. This compound is unstable and was used in subsequent reaction without further characterization. In a sealed reaction tube, a solution of cyclopropylamine $(0.40$ $\mathrm{mL}, 6.93 \mathrm{mmol})$ and above tosylate $(0.60 \mathrm{~g}, 1.73 \mathrm{mmol})$ in acetonitrile $(5.00 \mathrm{~mL})$ was heated at $90{ }^{\circ} \mathrm{C}$ for 18 hours. The reaction was cooled to room temperature and concentrated in vacuo. The residue was diluted with $\mathrm{CH}_{2} \mathrm{Cl}_{2}(10 \mathrm{~mL})$ and washed with sat. aq. $\mathrm{NaHCO}_{3}(20 \mathrm{~mL})$. The organic layer was dried over $\mathrm{MgSO}_{4}$ and concentrated in vacuo. The residue was dissolved in $\mathrm{CH}_{2} \mathrm{Cl}_{2}(10.0$ $\mathrm{mL})$ and cooled to $0{ }^{\circ} \mathrm{C}$, triethylamine $(0.48 \mathrm{~mL}, 3.46 \mathrm{mmol})$ and cyclohexyl isocyanate $(0.22 \mathrm{~mL}$, $1.73 \mathrm{mmol}$ ) were added, the reaction mixture was warmed to room temperature and stirred for 18 
hours. The solution was washed with water $(20 \mathrm{~mL})$, aq. $1 \mathrm{M} \mathrm{HCl}(20 \mathrm{~mL})$, sat. aq. $\mathrm{NaHCO}_{3}(20$ $\mathrm{mL})$ and brine $(20 \mathrm{~mL})$. The organic layer was dried over $\mathrm{MgSO}_{4}$ and concentrated in vacuo. The residue was purified by flash column chromatography (30\% EtOAc/Hexane) to afford the title compound $\mathbf{1 j}$ as a single isomer $(101 \mathrm{mg}, 16 \%)$ as a colorless oil; $v_{\max } / \mathrm{cm}^{-1}: 2928(\mathrm{~m}), 2853(\mathrm{w})$, $1651(\mathrm{~m}), 1507$ (s), $1228(\mathrm{~m}) ;{ }^{1} \mathrm{H}$ NMR $\left(\mathrm{CDCl}_{3}, 500 \mathrm{MHz}\right): \delta 7.34-7.30(\mathrm{~m}, 2 \mathrm{H}), 6.98(\mathrm{dd}, J=$ 8.7, 8.7 Hz, 2H), $6.65(\mathrm{dd}, J=15.7,10.4 \mathrm{~Hz}, 1 \mathrm{H}), 6.39$ (d, $J=15.7 \mathrm{~Hz}, 1 \mathrm{H}), 6.22$ (dd, $J=15.0$, $10.4 \mathrm{~Hz}, 1 \mathrm{H}), 5.80(\mathrm{dt}, J=15.0,7.5 \mathrm{~Hz}, 1 \mathrm{H}), 5.10(\mathrm{~d}, J=7.5 \mathrm{~Hz}, 1 \mathrm{H}), 3.70-3.61(\mathrm{~m}, 1 \mathrm{H}), 3.41$ $(\mathrm{t}, J=7.0 \mathrm{~Hz}, 2 \mathrm{H}), 2.47-2.37(\mathrm{~m}, 3 \mathrm{H}), 1.96-1.89(\mathrm{~m}, 2 \mathrm{H}), 1.70-1.63(\mathrm{~m}, 2 \mathrm{H}), 1.60-1.59(\mathrm{~m}$, $1 \mathrm{H}), 1.43-1.32(\mathrm{~m}, 2 \mathrm{H}), 1.22-1.07(\mathrm{~m}, 3 \mathrm{H}), 0.85-0.80(\mathrm{~m}, 3 \mathrm{H}), 0.72-0.68(\mathrm{~m}, 2 \mathrm{H}) ;{ }^{13} \mathrm{C} \mathrm{NMR}$ $\left(\mathrm{CDCl}_{3}, 125 \mathrm{MHz}\right): \delta 162.21(\mathrm{~d}, J=246.6 \mathrm{~Hz}, 158.3,133.86(\mathrm{~d}, J=3.2 \mathrm{~Hz}), 132.8,132.1,129.3$, $129.1(\mathrm{~d}, J=2.4 \mathrm{~Hz}), 127.7$ (d, $J=7.9 \mathrm{~Hz}), 115.6(\mathrm{~d}, J=21.6 \mathrm{~Hz}), 49.1,46.6,34.1,32.3,27.7$, 25.9, 25.1, 8.8; ${ }^{19} \mathrm{~F}$ NMR $\left(\mathrm{CDCl}_{3}, 376 \mathrm{MHz}\right)$ : -114.79 (tt, $J=9.0,5.3 \mathrm{~Hz}$ ); HRMS: $\left(\mathrm{ESI}^{+}\right.$) calculated for $\mathrm{C}_{22} \mathrm{H}_{30} \mathrm{FN}_{2} \mathrm{O}: 357.2337$, found $[\mathrm{M}+\mathrm{H}]^{+}:$357.2336. This compound is unstable and was stored as a frozen matrix in benzene.

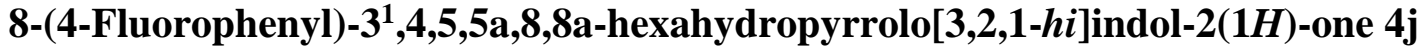

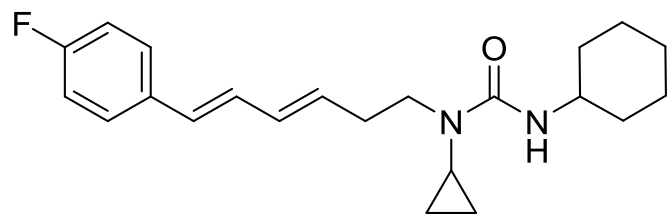

$1 \mathrm{j}$

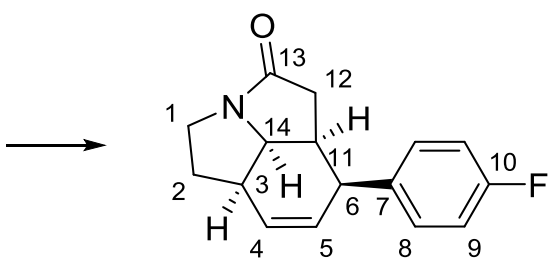

$4 \mathbf{j}$

To an oven dried reaction tube, fitted with a magnetic stirrer, was charged with $\mathbf{1 j}$ (35.6 $\mathrm{mg}, 0.10$ mmol), P(4-F- $\left.\mathrm{C}_{6} \mathrm{H}_{4}\right)_{3}(4.70 \mathrm{mg}, 15.00 \mu \mathrm{mol}),\left[\mathrm{Rh}(\mathrm{cod})_{2}\right] \mathrm{OTf}(3.50 \mathrm{mg}, 7.50 \mu \mathrm{mol})$, dimethyl fumarate $(14.4 \mathrm{mg}, 0.10 \mathrm{mmol})$ and BHT $(2.20 \mathrm{mg}, 0.01 \mathrm{mmol})$. The tube was fitted with a rubber septum and purged with argon. Anhydrous benzonitrile $(1.00 \mathrm{~mL})$ was added via syringe. The reaction vessel was purged with $\mathrm{CO}$ for 10 minutes and then the solution was sparged with $\mathrm{CO}$ for approximately 20 seconds. The mixture was heated at $140{ }^{\circ} \mathrm{C}$ for 72 hours, under a $\mathrm{CO}$ atmosphere (with $\mathrm{CO}$ balloon attached, $1 \mathrm{~atm}$ ). The mixture was cooled to room temperature and concentrated in vacuo. The residue was purified by flash column chromatography $\left(20 \%\right.$ Acetonitrile $/ \mathrm{CH}_{2} \mathrm{Cl}_{2}$, then $90 \%$ EtOAc/Hexane) to afford the title compound $\mathbf{4 j}(12.1 \mathrm{mg}, 47 \%)$ as a pale yellow oil; $v_{\max } / \mathrm{cm}^{-1}: 2928(\mathrm{w}), 1687$ (s), 1510 (s), 1410 (m), 1222 (s), 1160 (w), $822(\mathrm{~m}) ;{ }^{1} \mathrm{H}^{\mathrm{N} M R}\left(\mathrm{CDCl}_{3}\right.$, $400 \mathrm{MHz}): \delta 7.20(\mathrm{dd}, J=8.5,5.3 \mathrm{~Hz}, 2 \mathrm{H}, 2 \times \mathrm{C} 8 \underline{\mathrm{H}}), 7.04(\mathrm{dd}, J=8.5,8.5 \mathrm{~Hz}, 2 \mathrm{H}, 2 \times \mathrm{C} 9-\underline{\mathrm{H}})$, $6.11(\mathrm{dd}, J=9.8,2.8 \mathrm{~Hz}, 1 \mathrm{H}, 1 \times \mathrm{C} 4-\underline{\mathrm{H}}), 5.68(\mathrm{~d}, J=9.8 \mathrm{~Hz}, 1 \mathrm{H}, 1 \times \mathrm{C} 5-\underline{\mathrm{H}}), 4.27(\mathrm{dd}, J=8.4,6.4$ $\mathrm{Hz}, 1 \mathrm{H}, 1 \times \mathrm{C} 14-\underline{\mathrm{H}}), 3.62\left(\mathrm{dd}, J=11.7,8.6 \mathrm{~Hz}, 1 \mathrm{H}, 1 \times \mathrm{C} 1-\underline{\mathrm{H}}_{2}\right), 3.56-3.51(\mathrm{~m}, 1 \mathrm{H}, 1 \times \mathrm{C6}-\underline{\mathrm{H}})$, 
$3.08-2.94\left(\mathrm{~m}, 2 \mathrm{H}, 1 \times \mathrm{C} 11-\underline{\mathrm{H}}, 1 \times \mathrm{C} 1-\mathrm{H}_{2}\right), 2.62-2.56(\mathrm{~m}, 1 \mathrm{H}, 1 \times \mathrm{C} 3-\underline{\mathrm{H}}), 2.40-2.28(\mathrm{~m}, 2 \mathrm{H}, 1$ $\left.\times \mathrm{C} 2-\underline{\mathrm{H}}_{2}, 1 \times \mathrm{C} 12-\underline{\mathrm{H}}_{2}\right), 2.17-2.02\left(\mathrm{~m}, 2 \mathrm{H}, 1 \times \mathrm{C} 2-\mathrm{H}_{2}, 1 \times \mathrm{C} 12-\mathrm{H}_{2}\right) ;{ }^{13} \mathrm{C} \mathrm{NMR}\left(\mathrm{CDCl}_{3}, 125 \mathrm{MHz}\right)$ : $\delta 176.6$ (C13), 161.8 (d, $J=245.3 \mathrm{~Hz}, \mathrm{C10}), 137.4$ (d, $J=3.3 \mathrm{~Hz}, \mathrm{C7}), 133.7$ (C5), 131.2 (C4), $129.6(\mathrm{~d}, J=7.9 \mathrm{~Hz}, \mathrm{C8}), 115.7$ (d, $J=21.2 \mathrm{~Hz}, \mathrm{C9}), 64.9$ (C14), 41.3, 41.2 (C1 and C6), 36.3 (C3), 35.9 (C12), 34.9 (C11), 32.8 (C2); $\left.{ }^{19} \mathrm{~F} \mathrm{NMR} \mathrm{(} \mathrm{CDCl}_{3}, 376 \mathrm{MHz}\right)$ : -116.15 (tt, $J=9.2,5.2$ $\mathrm{Hz}$ ); HRMS: $\left(\mathrm{ESI}^{+}\right)$calculated for $\mathrm{C}_{16} \mathrm{H}_{17} \mathrm{NOF}: 258.1289$, found $[\mathrm{M}+\mathrm{H}]^{+}: 258.1283$. The relative stereochemistry of this compound was assigned by analogy to that of $\mathbf{4 i}$

\section{Refer to Scheme 4 in the main paper}

Scheme 4A:

$N$-(4-Phenylbut-3-yn-1-yl)cyclopropanamine 5k
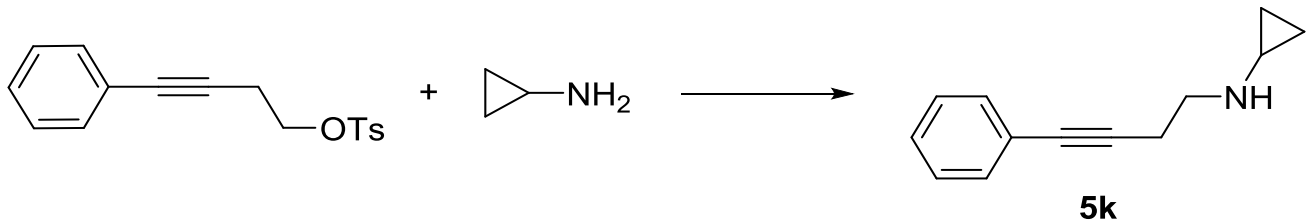

General procedure A: 4-phenylbut-3-yn-1-yl 4-methylbenzenesulfonate (2.13g $7.10 \mathrm{mmol})$ (prepared according to the literature procedure ${ }^{12}$ ) was employed. The crude mixture was purified by flash column chromatography (35\% EtOAc/Hexane) to afford the title compound $\mathbf{5 k}(1.12 \mathrm{~g}$, 85\%) as a yellow oil; $v_{\max } / \mathrm{cm}^{-1}: 3749(\mathrm{~m}), 2926(\mathrm{M}), 1490$ (s), 1441 (s), 1346 (s), 755 (s); ${ }^{1} \mathrm{H}$ NMR (400 MHz, $\left.\mathrm{CDCl}_{3}\right): \delta 7.41-7.37(2 \mathrm{H}, \mathrm{m}), 7.29-7.24(3 \mathrm{H}, \mathrm{m}), 2.92(2 \mathrm{H}, \mathrm{t}, J=6.6 \mathrm{~Hz})$, $2.61(2 \mathrm{H}, \mathrm{t}, J=6.6 \mathrm{~Hz}), 2.21-2.16(1 \mathrm{H}, \mathrm{m}), 0.47-0.34(4 \mathrm{H}, \mathrm{m}) ;{ }^{13} \mathrm{C} \mathrm{NMR}\left(100 \mathrm{MHz}, \mathrm{CDCl}_{3}\right)$ : $\delta$ 131.6, 128.2, 127.7, 123.6, 88.0, 81.7, 47.9, 29.6, 20.5, 6.3; m/z $\left(\mathrm{ESI}^{+}\right) \mathrm{HRMS}: \mathrm{C}_{13} \mathrm{H}_{16} \mathrm{~N}$ : 186.1277. Found $[\mathrm{M}+\mathrm{H}]^{+}: 186.1274$.

\section{3-Cyclohexyl-1-cyclopropyl-1-(4-phenylbut-3-yn-1-yl)urea 1k}

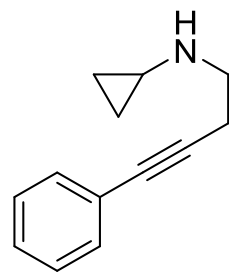

$5 k$

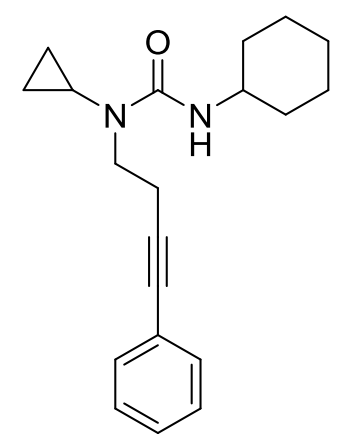

$1 k$ 
General procedure B: Compound 5k $(0.30 \mathrm{~g}, 1.65 \mathrm{mmol})$ and cyclohexyl isocyanate $(0.19 \mathrm{~mL}$, $1.50 \mathrm{mmol}$ ) were employed. The crude mixture was purified by flash column chromatography (10\% EtOAc/Hexane) to afford the title compound 1k (311 mg, 67\%) as a colorless solid; m.p. 66-68 ${ }^{\circ} \mathrm{C}$ (Hexane/EtOAc); $v_{\max } / \mathrm{cm}^{-1}: 3345$ (m), 2927 (m), 1646 (s), 1506 (s), 1317 (s), 755 (s); ${ }^{1} \mathrm{H}$ NMR (400 MHz, $\left.\mathrm{CDCl}_{3}\right): \delta 7.31-7.29(\mathrm{~m}, 2 \mathrm{H}), 7.21-7.17(\mathrm{~m}, 3 \mathrm{H}), 5.09(\mathrm{~d}, J=8.0 \mathrm{~Hz}, 1 \mathrm{H})$, 3.60 (dddd, $J=14.3,10.3,7.9,3.9 \mathrm{~Hz}, 1 \mathrm{H}), 3.49$ (t, $J=6.8 \mathrm{~Hz}, 2 \mathrm{H}), 2.60$ (t, $J=6.8 \mathrm{~Hz}, 2 \mathrm{H}), 2.53$ - $2.50(\mathrm{~m}, 1 \mathrm{H}), 1.88-1.83(\mathrm{~m}, 2 \mathrm{H}), 1.64-1.48(\mathrm{~m}, 3 \mathrm{H}), 1.36-1.25(\mathrm{~m}, 2 \mathrm{H}), 1.16$ - 1.02 (m, $3 \mathrm{H}), 0.80-0.70(\mathrm{~m}, 4 \mathrm{H}) ;{ }^{13} \mathrm{C} \mathrm{NMR}\left(100 \mathrm{MHz}, \mathrm{CDCl}_{3}\right): \delta 157.9,131.4,128.1,127.6,123.8,88.3$, 81.5, 48.9, 46.4, 33.8, 28.2, 25.7, 24.9, 19.4, 8.9. $\mathrm{m} / \mathrm{z}$ (ESI $\left.{ }^{+}\right) \mathrm{HRMS}$ : Calculated for $\mathrm{C}_{20} \mathrm{H}_{27} \mathrm{~N}_{2} \mathrm{O}$ : 311.2118. Found $[\mathrm{M}+\mathrm{H}]^{+}: 311.2106$.

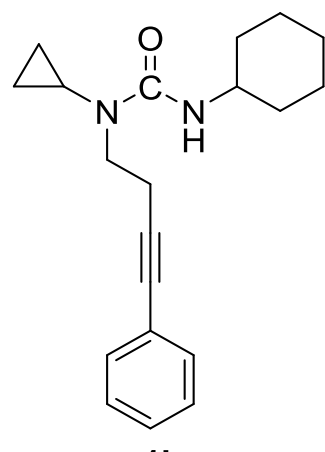

$1 \mathrm{k}$

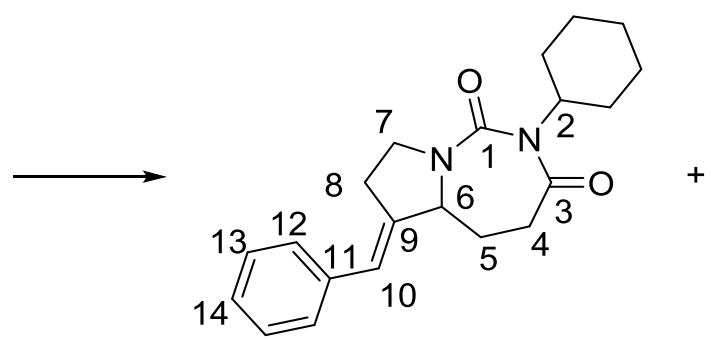

3k

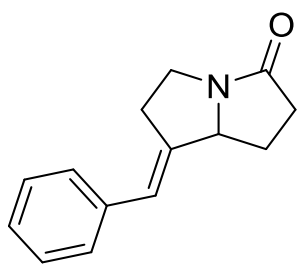

$4 \mathbf{k}$

\begin{tabular}{|c|c|c|}
\hline $\mathrm{T}\left({ }^{\circ} \mathrm{C}\right)$ & Yield of 3k $(\%)$ & Yield of 4k $(\%)$ \\
\hline 100 & 33 & 0 \\
\hline 120 & 35 & 21 \\
\hline 130 & 18 & 50 \\
\hline 140 & 0 & 52 \\
\hline
\end{tabular}

Four identical, oven dried reaction tubes were fitted with a magnetic stirrer and charged with $\left[\mathrm{Rh}(\operatorname{cod})_{2}\right] \mathrm{OTf}(3.52 \mathrm{mg}, 7.50 \mu \mathrm{mol})$, 4-(dimethylamino)benzoic acid $(2.48 \mathrm{mg}, 15.0 \mu \mathrm{mol})$, tris $(4-$ fluorophenyl)phosphine $(4.47 \mathrm{mg}, 15.0 \mu \mathrm{mol}), \mathrm{Na}_{2} \mathrm{SO}_{4}(14.2 \mathrm{mg}, 0.10 \mathrm{mmol})$ and $1 \mathrm{k}(31.0 \mathrm{mg}$, $0.10 \mathrm{mmol})$. Each tube was fitted with a rubber septum and purged with argon. Anhydrous 1,2DCB $(1.00 \mathrm{~mL})$ was added by syringe to each tube. The reaction vessels were purged with CO for 10 minutes and the solutions were subsequently sparged with CO for approximately 20 seconds. These reaction tubes were heated at $100{ }^{\circ} \mathrm{C}, 120{ }^{\circ} \mathrm{C}, 130{ }^{\circ} \mathrm{C}, 140{ }^{\circ} \mathrm{C}$, respectively, under a CO atmosphere for 20 hours. The mixtures were cooled to room temperature and concentrated in vacuo. The in-situ yields of product $\mathbf{3 k}$ and $\mathbf{4 k}$ were determined by ${ }^{1} \mathrm{H}$ NMR analysis using 1,4dinitrobenzene as an internal standard. 
Compound 3k could be isolated by flash column chromatography (10\% EtOAc/Hexane) as a yellow solid; m.p. 95-97 ${ }^{\circ} \mathrm{C}$ (Hexane/EtOAc); $v_{\max } / \mathrm{cm}^{-1}: 2928$ (m), 1690 (s), 1650 (m), 1420 (s), 1165 (s), 730 (s); ${ }^{1} \mathrm{H}$ NMR (400 MHz, $\mathrm{CDCl}_{3}$ ): $\delta 7.31$ - 7.27 (m, 2H, $2 \times \mathrm{C12}-\underline{\mathrm{H}}$ ), 7.20 - 7.16 (m, $3 \mathrm{H}, 2 \times \mathrm{C13}-\underline{\mathrm{H}}, 1 \times \mathrm{C14}-\underline{\mathrm{H}}), 6.30(\mathrm{dd}, J=2.1,2.1 \mathrm{~Hz}, 1 \mathrm{H}, 1 \times \mathrm{C10}-\underline{\mathrm{H}}), 4.39(\mathrm{dd}, J=12.1,6.5 \mathrm{~Hz}$, $1 \mathrm{H}, 1 \times \mathrm{C6}-\underline{\mathrm{H}}), 4.19(\mathrm{dddd}, J=12.1,12.1,3.7,3.7 \mathrm{~Hz}, 1 \mathrm{H}, 1 \times \mathrm{C} 2-\underline{\mathrm{H}}), 3.78(\mathrm{ddd}, J=11.8,7.9$, $\left.7.9 \mathrm{~Hz}, 1 \mathrm{H}, 1 \times \mathrm{C} 7-\underline{\mathrm{H}}_{2}\right), 3.65-3.58\left(\mathrm{~m}, 1 \mathrm{H}, 1 \times \mathrm{C} 7-\underline{\mathrm{H}}_{2}\right), 2.91-2.87\left(\mathrm{~m}, 2 \mathrm{H}, 2 \times \mathrm{C8}-\underline{\mathrm{H}}_{2}\right), 2.60-$ $2.46\left(\mathrm{~m}, 2 \mathrm{H}, 2 \times \mathrm{C} 4-\underline{\mathrm{H}}_{2}\right), 2.41-2.32\left(\mathrm{~m}, 1 \mathrm{H}, 1 \times \mathrm{C} 5-\underline{\mathrm{H}}_{2}\right), 2.06-1.70\left(\mathrm{~m}, 6 \mathrm{H}, 1 \times \mathrm{C} 5-\underline{\mathrm{H}}_{2}, 5 \times \mathrm{CHex}^{-}\right.$ $\left.\underline{\mathrm{H}}_{2}\right), 1.57-1.47\left(\mathrm{~m}, 2 \mathrm{H}, 2 \times \mathrm{CHex}_{\mathbf{H}} \underline{\mathrm{H}}_{2}\right), 1.34-1.05$ (m, 3H , $\left.3 \times \mathrm{C}_{\text {Hex }}-\underline{\mathrm{H}}_{2}\right) ;{ }^{13} \mathrm{C} \mathrm{NMR}(100 \mathrm{MHz}$, $\mathrm{CDCl}_{3}$ ): $\delta 170.8$ (C3), 155.0 (C1), 140.8 (C9), 136.4 (C11), 128.4 (C12), 128.3 (C13), 127.2 (C14), 123.0 (C10), 61.3 (C6), 55.1 (C2), 45.7 (C7), 34.8 (C5), 34.3 (C4), 31.6 (CHex), 29.2 (CHex), 27.5 (C8), 26.2 (CHex), 26.1 (CHex), 25.3 (CHex); m/z (ESI ${ }^{+}$) HRMS: Calculated for $\mathrm{C}_{21} \mathrm{H}_{27} \mathrm{~N}_{2} \mathrm{O}_{2}$ : 339.2067. Found $[\mathrm{M}+\mathrm{H}]^{+}: 339.2057$.

Compound $4 \mathbf{k}$ could be isolated by flash column chromatography $\left(10 \%\right.$ Acetonitrile $\left./ \mathrm{CH}_{2} \mathrm{Cl}_{2}\right)$ as a yellow oil; ${ }^{1} \mathrm{H}$ NMR (400 MHz, $\left.\mathrm{CDCl}_{3}\right): \delta 7.35-7.20(\mathrm{~m}, 5 \mathrm{H}), 6.32(\mathrm{dd}, J=2.5 \mathrm{~Hz}, 1 \mathrm{H}), 4.55$ (ddd, $J=7.7,7.7,2.0 \mathrm{~Hz}, 1 \mathrm{H}), 4.03$ (ddd, $J=11.8,7.3,4.7 \mathrm{~Hz}, 1 \mathrm{H}$ ), 3.09 (ddd, $J=11.8,8.0,1.5$ $\mathrm{Hz}, 1 \mathrm{H}), 2.93-2.89(\mathrm{~m}, 2 \mathrm{H}), 2.77-2.68(\mathrm{~m}, 1 \mathrm{H}), 2.53(\mathrm{dddd}, J=12.5,9.0,7.3,2.0 \mathrm{~Hz}, 1 \mathrm{H}), 2.42$ (ddd, $J=16.4,9.4,2.0 \mathrm{~Hz}, 1 \mathrm{H}), 1.94$ (dddd, $J=12.5,11.1,9.4,7.7 \mathrm{~Hz}, 1 \mathrm{H}) ;{ }^{13} \mathrm{C} \mathrm{NMR}(100 \mathrm{MHz}$, $\left.\mathrm{CDCl}_{3}\right): \delta 175.5,142.8,136.9,128.4,128.2,126.9,122.2,64.9,41.6,33.9,31.7,27.9$. The spectroscopic properties of this compound were consistent with the data available in the literature. 13

\section{Scheme 4B:}

(E)-7-Benzylidenehexahydro-3H-pyrrolizin-3-one 4k

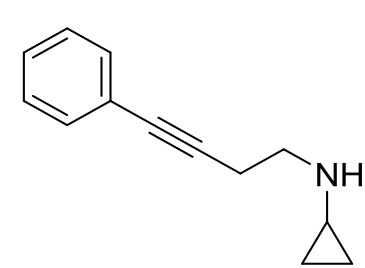

5k

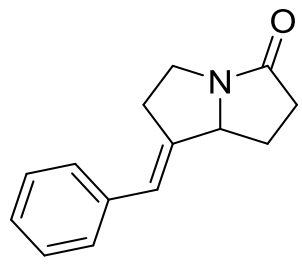

4k

General procedure D: Compound 5k $(27.8 \mathrm{mg}, 0.15 \mathrm{mmol})$ and cyclohexyl isocyanate $(19.0 \mu \mathrm{L}$, $0.15 \mathrm{mmol}$ ) were employed. The crude mixture was purified by flash column chromatography (10\% Acetonitrile/ $\left.\mathrm{CH}_{2} \mathrm{Cl}_{2}\right)$ to afford the title compound $4 \mathbf{k}(24.9 \mathrm{mg}, 77 \%)$ as a yellow oil. 

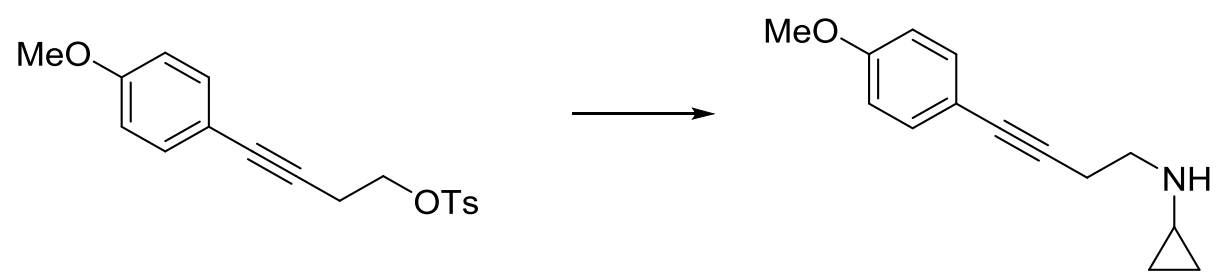

5I

General procedure A: 4-(4-Methoxyphenyl)but-3-yn-1-yl 4-methylbenzenesulfonate (1.98 g, $6.00 \mathrm{mmol}$, prepared according to the literature procedure ${ }^{12}$ ) was employed. The crude mixture was purified by flash column chromatography (50\% EtOAc/Hexane) to afford the title compound $5 \mathbf{l}(0.83 \mathrm{~g}, 64 \%)$ as a pale yellow oil; $v_{\max } / \mathrm{cm}^{-1}: 2932(\mathrm{w}), 2836(\mathrm{w}), 1606(\mathrm{~m}), 1508(\mathrm{~s}), 1288$ (m), 1243 (s), 1172 (m), 1032 (m), 830 (s); ${ }^{1} \mathrm{H}$ NMR $\left(\mathrm{CDCl}_{3}, 400 \mathrm{MHz}\right): \delta 7.36-7.32$ (m, 2H, $6.84-6.79(\mathrm{~m}, 2 \mathrm{H}), 3.80(\mathrm{~s}, 3 \mathrm{H}), 2.92(\mathrm{t}, J=6.6 \mathrm{~Hz}, 2 \mathrm{H}), 2.60(\mathrm{t}, J=6.6 \mathrm{~Hz}, 2 \mathrm{H}), 2.19(\mathrm{tt}, J=$ 6.6, 3.6 Hz, 1H), 1.88 (br. s, $1 \mathrm{H}), 0.48-0.41(\mathrm{~m}, 2 \mathrm{H}), 0.40-0.34(\mathrm{~m}, 2 \mathrm{H}) ;{ }^{13} \mathrm{C} \mathrm{NMR}\left(\mathrm{CDCl}_{3}, 100\right.$ $\mathrm{MHz}): \delta 159.3,133.1,115.9,113.9,86.5,81.6,55.4,48.1,29.9,20.6,6.5$; HRMS: $\left(\mathrm{ESI}^{+}\right)$ calculated for $\mathrm{C}_{14} \mathrm{H}_{19} \mathrm{NO}: 216.1383$, found $[\mathrm{M}+\mathrm{H}]^{+}: 216.1380$.

(E)-7-(4-Methoxybenzylidene)hexahydro-3H-pyrrolizin-3-one 41

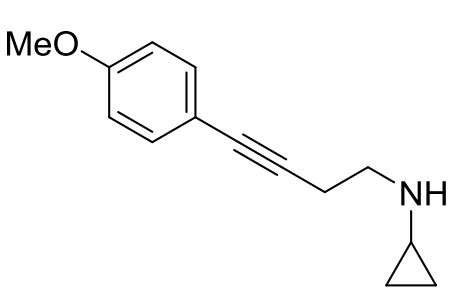

51

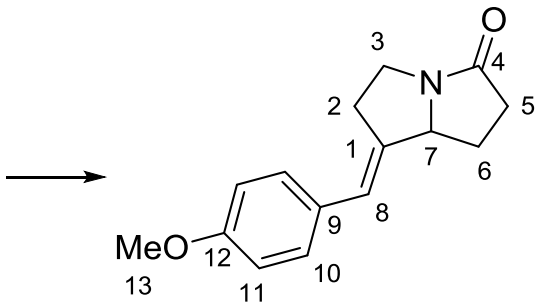

41

General procedure D: Compound $5 \mathbf{l}(32.3 \mathrm{mg}, 0.15 \mathrm{mmol})$ and cyclohexyl isocyanate $(19.0 \mu \mathrm{L}$, $0.15 \mathrm{mmol}$ ) were employed. The crude mixture was purified by flash column chromatography (10\% Acetonitrile/ $\left.\mathrm{CH}_{2} \mathrm{Cl}_{2}\right)$ to afford the title compound $\mathbf{4 l}(27.3 \mathrm{mg}, 75 \%)$ as a pale brown oil;

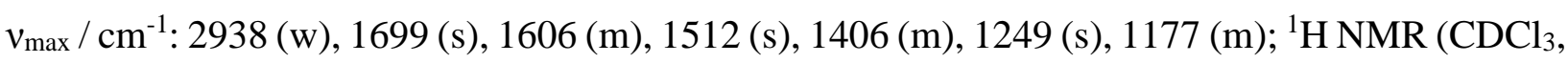
$500 \mathrm{MHz}): \delta 7.22(\mathrm{~d}, J=8.8 \mathrm{~Hz}, 2 \mathrm{H}, 2 \times \mathrm{C10}-\underline{\mathrm{H}}), 6.88(\mathrm{~d}, J=8.8 \mathrm{~Hz}, 2 \mathrm{H}, 2 \times \mathrm{C11}-\underline{\mathrm{H}}), 6.27$ (dd, $J=2.5,2.5 \mathrm{~Hz}, 1 \mathrm{H}, 1 \times \mathrm{C} 8-\underline{\mathrm{H}}), 4.55(\mathrm{td}, J=7.5,1.9 \mathrm{~Hz}, 1 \mathrm{H}, 1 \times \mathrm{C} 7-\underline{\mathrm{H}}), 4.03(\mathrm{ddd}, J=11.8,7.4$, $\left.4.6 \mathrm{~Hz}, 1 \mathrm{H}, 1 \times \mathrm{C} 3-\underline{\mathrm{H}}_{2}\right), 3.81\left(\mathrm{~s}, 3 \mathrm{H}, 3 \times \mathrm{C} 13-\underline{\mathrm{H}}_{3}\right), 3.15-3.03\left(\mathrm{~m}, 1 \mathrm{H}, 1 \times \mathrm{C} 3-\underline{\mathrm{H}}_{2}\right), 2.93-2.85(\mathrm{~m}$, $\left.2 \mathrm{H}, 2 \times \mathrm{C} 2-\underline{\mathrm{H}}_{2}\right), 2.73\left(\mathrm{dddd}, J=16.5,10.9,8.9,1.4 \mathrm{~Hz}, 1 \mathrm{H}, 1 \times \mathrm{C} 5-\underline{\mathrm{H}}_{2}\right), 2.52$ (dddd, $J=12.5,9.2$, 7.5, $\left.1.9 \mathrm{~Hz}, 1 \mathrm{H}, 1 \times \mathrm{C6}-\underline{\mathrm{H}}_{2}\right), 2.42\left(\mathrm{ddd}, J=16.5,9.2,2.0 \mathrm{~Hz}, 1 \mathrm{H}, 1 \times \mathrm{C5}-\underline{\mathrm{H}}_{2}\right), 1.97-1.89$ (m, $1 \mathrm{H}$, $\left.1 \times \mathrm{C6}-\underline{\mathrm{H}}_{2}\right) ;{ }^{13} \mathrm{C} \mathrm{NMR}\left(\mathrm{CDCl}_{3}, 126 \mathrm{MHz}\right): \delta 175.6(\mathrm{C4}), 158.6$ (C12), 140.5 (C1), $129.9(\mathrm{C9})$, 129.6 (C10), 121.7 (C8), 114.0 (C11), 65.0 (C7), 55.4 (C13), 41.7 (C3), 34.1 (C5), 31.7 (C2), 28.1 
(C6); HRMS: $\left(\mathrm{ESI}^{+}\right)$calculated for $\mathrm{C}_{15} \mathrm{H}_{18} \mathrm{NO}_{2}$ : 244.1332, found $[\mathrm{M}+\mathrm{H}]^{+}$: 244.1333. This compound is unstable and was stored as a frozen matrix in benzene.

$N$-(4-(4-Fluorophenyl)but-3-yn-1-yl)cyclopropanamine 5m

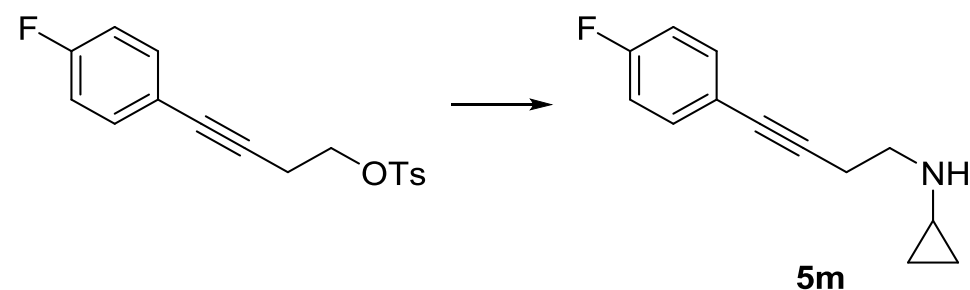

General procedure A: 4-(4-Fluorophenyl)but-3-yn-1-yl 4-methylbenzenesulfonate (1.91 g, 6.00 mmol, prepared according to the literature procedure ${ }^{12}$ ) was employed. The crude mixture was purified by flash column chromatography (40\% EtOAc/Hexane) to afford the title compound $\mathbf{5 m}$ $(0.82 \mathrm{~g}, 67 \%)$ as a pale yellow oil; $v_{\max } / \mathrm{cm}^{-1}: 2928(\mathrm{~m}), 1506(\mathrm{~s}), 1220(\mathrm{~s}), 1156(\mathrm{~m}), 1093(\mathrm{~m})$, $1014(\mathrm{~m}), 834(\mathrm{~s}) ;{ }^{1} \mathrm{H}$ NMR $\left(\mathrm{CDCl}_{3}, 400 \mathrm{MHz}\right): \delta 7.40-7.34(\mathrm{~m}, 2 \mathrm{H}), 7.02-6.94(\mathrm{~m}, 2 \mathrm{H}), 2.92$ (t, $J=6.7 \mathrm{~Hz}, 2 \mathrm{H}), 2.60$ (t, $J=6.7 \mathrm{~Hz}, 2 \mathrm{H}), 2.19$ (tt, $J=6.6,3.6 \mathrm{~Hz}, 1 \mathrm{H}), 1.87$ (br. s, 1H), $0.49-$ $0.43(\mathrm{~m}, 2 \mathrm{H}), 0.40-0.34(\mathrm{~m}, 2 \mathrm{H}) ;{ }^{13} \mathrm{C} \mathrm{NMR}\left(\mathrm{CDCl}_{3}, 100 \mathrm{MHz}\right): \delta 162.3(\mathrm{~d}, J=248.2 \mathrm{~Hz}), 133.5$ $(\mathrm{d}, J=8.2 \mathrm{~Hz}), 119.9(\mathrm{~d}, J=3.4 \mathrm{~Hz}), 115.6(\mathrm{~d}, J=22.1 \mathrm{~Hz}), 87.9(\mathrm{~d}, J=1.4 \mathrm{~Hz}), 80.8,48.0,29.8$, 20.6, 6.5; ${ }^{19} \mathrm{~F} \mathrm{NMR}\left(\mathrm{CDCl}_{3}, 376 \mathrm{MHz}\right)$ : -111.87 (tt, $\left.J=8.6,5.4 \mathrm{~Hz}\right)$; HRMS: $\left(\mathrm{ESI}^{+}\right)$calculated for $\mathrm{C}_{13} \mathrm{H}_{15} \mathrm{FN}: 204.1183$, found $[\mathrm{M}+\mathrm{H}]^{+}: 204.1183$.

(E)-7-(4-Fluorobenzylidene)hexahydro-3H-pyrrolizin-3-one $4 \mathrm{~m}$

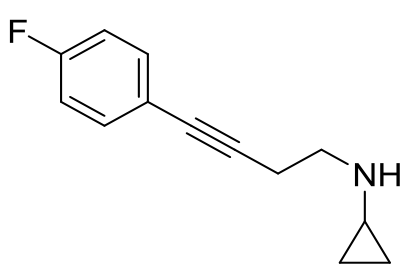

$5 \mathrm{~m}$

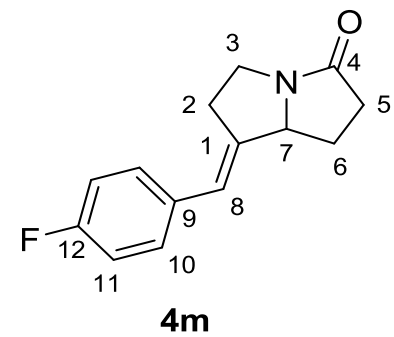

$4 \mathrm{~m}$

General procedure D: Compound $5 \mathrm{~m}(30.5 \mathrm{mg}, 0.15 \mathrm{mmol})$ and cyclohexyl isocyanate $(19.0 \mu \mathrm{L}$, $0.15 \mathrm{mmol}$ ) were employed. The crude mixture was purified by flash column chromatography (10\% Acetonitrile/ $\left.\mathrm{CH}_{2} \mathrm{Cl}_{2}\right)$ to afford the title compound $\mathbf{4 m}(23.3 \mathrm{mg}, 67 \%)$ as a pale brown oil; $v_{\max } / \mathrm{cm}^{-1}: 2932$ (w), 1691 (s), 1601 (m), 1508 (s), 1407 (m), 1224 (s), 1159 (m), 832 (m); ${ }^{1} \mathrm{H}$ NMR $\left(\mathrm{CDCl}_{3}, 400 \mathrm{MHz}\right): \delta 7.23(\mathrm{dd}, J=8.5,5.0 \mathrm{~Hz}, 2 \mathrm{H}, 2 \times \mathrm{C10}-\underline{\mathrm{H}}), 7.07-6.99(\mathrm{~m}, 2 \mathrm{H}, 2 \times$ C11- $\underline{\mathrm{H}}), 6.29(\mathrm{~d}, J=2.7 \mathrm{~Hz}, 1 \mathrm{H}, 1 \times \mathrm{C} 8-\underline{\mathrm{H}}), 4.55(\mathrm{t}, J=7.6 \mathrm{~Hz}, 1 \mathrm{H}, 1 \times \mathrm{C} 7-\underline{\mathrm{H}}), 4.04(\mathrm{ddd}, J=$ 11.8, 7.0, 4.8 Hz, 1H, $\left.1 \times \mathrm{C} 3-\underline{\mathrm{H}}_{2}\right), 3.15-3.03\left(\mathrm{~m}, 1 \mathrm{H}, 1 \times \mathrm{C} 3-\underline{\mathrm{H}}_{2}\right), 2.91-2.83(\mathrm{~m}, 2 \mathrm{H}, 2 \times \mathrm{C} 2-$ $\left.\underline{\mathrm{H}}_{2}\right), 2.73\left(\mathrm{ddd}, J=16.5,9.9,9.5 \mathrm{~Hz}, 1 \mathrm{H}, 1 \times \mathrm{C} 5-\underline{\mathrm{H}}_{2}\right), 2.58-2.47\left(\mathrm{~m}, 1 \mathrm{H}, 1 \times \mathrm{C} 6-\underline{\mathrm{H}}_{2}\right), 2.42$ (ddd, 
$\left.J=16.5,9.4,1.9 \mathrm{~Hz}, 1 \mathrm{H}, 1 \times \mathrm{C} 5-\underline{\mathrm{H}}_{2}\right), 1.99-1.86\left(\mathrm{~m}, 1 \mathrm{H}, 1 \times \mathrm{C} 6-\underline{\mathrm{H}}_{2}\right) ;{ }^{13} \mathrm{C} \mathrm{NMR}\left(\mathrm{CDCl}_{3}, 100\right.$ MHz): $\delta 175.6(\mathrm{C4}), 161.70$ (d, $J=247.3 \mathrm{~Hz}, \mathrm{C12}), 142.6$ (C1), 133.2 (d, $J=3.2 \mathrm{~Hz}, \mathrm{C9}), 129.9$ (d, $J=8.0$ Hz, C10), 121.2 (C8), 115.5 (d, $J=21.5$ Hz, C11), 64.9 (C7), 41.7 (C3), 34.0 (C5), 31.7 (C2), 28.0 (C6); ${ }^{19} \mathrm{~F}$ NMR $\left(\mathrm{CDCl}_{3}, 376 \mathrm{MHz}\right)$ : -114.54 (tt, $\left.J=8.6,5.5 \mathrm{~Hz}\right)$; HRMS: (ESI $\left.{ }^{+}\right)$ calculated for $\mathrm{C}_{14} \mathrm{H}_{15} \mathrm{NOF}: 232.1132$, found $[\mathrm{M}+\mathrm{H}]^{+}: 232.1132$.

\section{4-(Thiophen-3-yl)but-3-yn-1-yl 4-methylbenzenesulfonate}

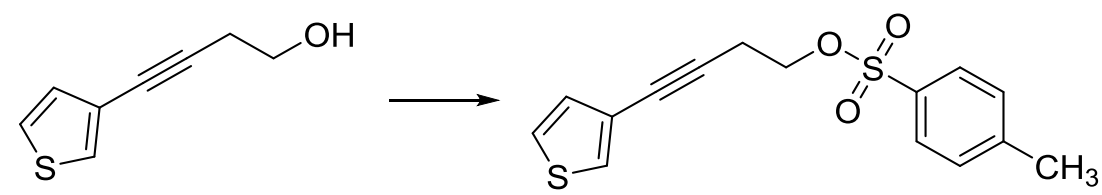

4-(Thiophen-3-yl)but-3-yn-1-ol (2.44 g, $16.0 \mathrm{mmol}$, prepared according to the literature procedure $\left.{ }^{14}\right)$ was dissolved in $\mathrm{CH}_{2} \mathrm{Cl}_{2}(35.0 \mathrm{~mL}), \quad \mathrm{Et}_{3} \mathrm{~N} \quad(1.94 \mathrm{~g}, 19.2 \mathrm{mmol})$, 4dimethylaminopyridine $(390 \mathrm{mg}, 3.2 \mathrm{mmol})$ and $\mathrm{TsCl}(3.65 \mathrm{~g}, 19.2 \mathrm{mmol})$ were added at $0{ }^{\circ} \mathrm{C}$. The reaction was then warmed to room temperature and stirred for 16 hours. Water $(80 \mathrm{~mL})$ was added and the solution was extracted with $\mathrm{CH}_{2} \mathrm{Cl}_{2}(3 \times 60 \mathrm{~mL})$. The organic extracts were combined, washed with brine $(60 \mathrm{~mL})$, dried over $\mathrm{MgSO}_{4}$ and concentrated in vacuo. The residue was purified by flash column chromatography (100\% toluene) to afford the title compound $(3.12 \mathrm{~g}, 99 \%)$ as an off-white solid; m.p. 51-53 ${ }^{\circ} \mathrm{C}\left(\mathrm{CH}_{2} \mathrm{Cl}_{2}\right) ; v_{\max } / \mathrm{cm}^{-1}: 2959$ (w), 1356 (s), 1189 (s), 1172 (s), 973 (s), 897 (s), 782 (s), 763 (s); ${ }^{1} \mathrm{H}$ NMR ( $\left.\mathrm{CDCl}_{3}, 400 \mathrm{MHz}\right): \delta 7.84-7.79$ (m, 2H), 7.35 - 7.29 (m, $3 \mathrm{H}), 7.23(\mathrm{dd}, J=5.0,3.0 \mathrm{~Hz}, 1 \mathrm{H}), 7.01(\mathrm{dd}, J=5.0,1.2 \mathrm{~Hz}, 1 \mathrm{H}), 4.17(\mathrm{t}, J=7.1 \mathrm{~Hz}, 2 \mathrm{H}), 2.76$ $(\mathrm{t}, J=7.1 \mathrm{~Hz}, 2 \mathrm{H}), 2.43(\mathrm{~s}, 3 \mathrm{H}) ;{ }^{13} \mathrm{C} \mathrm{NMR}\left(\mathrm{CDCl}_{3}, 100 \mathrm{MHz}\right): \delta 145.1,133.0,130.1,130.0,128.7$, 128.1, 125.3, 122.1, 83.5, 77.9, 67.8, 21.8, 20.5; HRMS: $\left(\mathrm{ESI}^{+}\right)$calculated for $\mathrm{C}_{15} \mathrm{H}_{15} \mathrm{O}_{3} \mathrm{~S}_{2}$ : 307.0457, found $[\mathrm{M}+\mathrm{H}]^{+}: 307.0452$.

\section{$N$-(4-(Thiophen-3-yl)but-3-yn-1-yl)cyclopropanamine 5n}
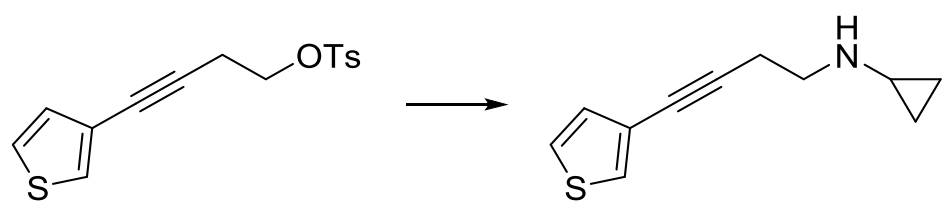

General procedure A: 4-(thiophen-3-yl)but-3-yn-1-yl 4-methylbenzenesulfonate (1.53 g, 5.00 mmol) was employed. The crude mixture was purified by flash column chromatography (30-40\% EtOAc/Hexane) to afford the title compound $5 \mathrm{n}(0.56 \mathrm{~g}, 58 \%)$ as a pale yellow oil; $v_{\max } / \mathrm{cm}^{-1}$ :

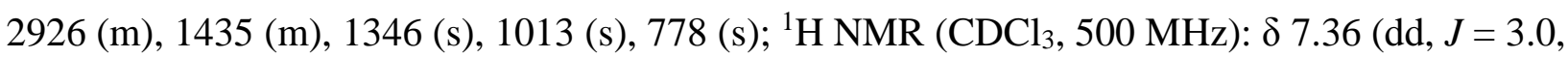
$1.2 \mathrm{~Hz}, 1 \mathrm{H}) 7.23(\mathrm{dd}, J=5.0,3.0 \mathrm{~Hz}, 1 \mathrm{H}) 7.08(\mathrm{dd}, J=5.0,1.2 \mathrm{~Hz}, 1 \mathrm{H}), 2.92(\mathrm{t}, J=6.7 \mathrm{~Hz}, 2 \mathrm{H})$, $2.60(\mathrm{t}, J=6.7 \mathrm{~Hz}, 2 \mathrm{H}), 2.19(\mathrm{tt}, J=6.6,3.6 \mathrm{~Hz}, 1 \mathrm{H}), 1.87$ (br. s, $1 \mathrm{H}), 0.48-0.42(\mathrm{~m}, 2 \mathrm{H}), 0.38-$ 
$0.34(\mathrm{~m}, 2 \mathrm{H}) ;{ }^{13} \mathrm{C} \mathrm{NMR}\left(\mathrm{CDCl}_{3}, 125 \mathrm{MHz}\right): \delta 130.1,128.0,125.2,122.8,87.8,76.8,48.0,29.8$, 20.6, 6.5; HRMS: $\left(\mathrm{ESI}^{+}\right)$calculated for $\mathrm{C}_{11} \mathrm{H}_{14} \mathrm{NS}: 192.0841$, found $[\mathrm{M}+\mathrm{H}]^{+}: 192.0835$.

(E)-7-(Thiophen-3-ylmethylene)hexahydro-3H-pyrrolizin-3-one 4n

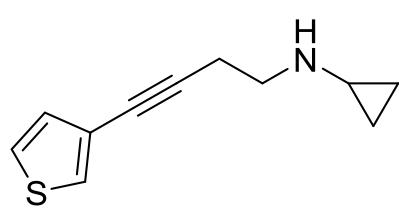

$5 n$

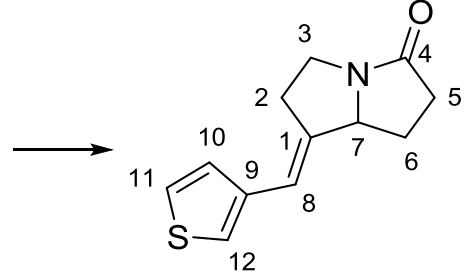

$4 n$

General procedure D: $N$-(4-(thiophen-3-yl)but-3-yn-1-yl)cyclopropanamine (28.7 mg, 0.15 mmol) and cyclohexyl isocyanate $(19.0 \mu \mathrm{L}, 0.15 \mathrm{mmol})$ were employed. The crude mixture was purified by flash column chromatography (10\% Acetonitrile/ $\left.\mathrm{CH}_{2} \mathrm{Cl}_{2}\right)$ to afford the title compound 4n (21.7 mg, 66\%) as a colorless oil; $v_{\max } / \mathrm{cm}^{-1}: 2931(\mathrm{w}), 1684(\mathrm{~s}), 1415(\mathrm{~m}), 1279(\mathrm{~m}), 777(\mathrm{~m})$, $637(\mathrm{~m}) ;{ }^{1} \mathrm{H} \mathrm{NMR}\left(\mathrm{CDCl}_{3}, 400 \mathrm{MHz}\right): \delta 7.31(\mathrm{dd}, J=5.0,2.9 \mathrm{~Hz}, 1 \mathrm{H}, 1 \times \mathrm{C} 11-\underline{\mathrm{H}}), 7.15-7.12$ $(\mathrm{m}, 1 \mathrm{H}, 1 \times \mathrm{C12}-\underline{\mathrm{H}}), 7.10(\mathrm{dd}, J=5.0,1.3 \mathrm{~Hz}, 1 \mathrm{H}, 1 \times \mathrm{C10}-\underline{\mathrm{H}}), 6.39-6.35(\mathrm{~m}, 1 \mathrm{H}, 1 \times \mathrm{C} 8-\underline{\mathrm{H}})$, $4.55(\mathrm{td}, J=7.6,2.1 \mathrm{~Hz}, 1 \mathrm{H}, 1 \times \mathrm{C} 7-\underline{\mathrm{H}}), 4.08\left(\mathrm{ddd}, J=11.9,7.1,4.9 \mathrm{~Hz}, 1 \mathrm{H}, 1 \times \mathrm{C} 3-\underline{\mathrm{H}}_{2}\right), 3.17-$ $3.08\left(\mathrm{~m}, 1 \mathrm{H}, 1 \times \mathrm{C} 3-\underline{\mathrm{H}}_{2}\right), 2.93-2.85\left(\mathrm{~m}, 2 \mathrm{H}, 2 \times \mathrm{C} 2-\underline{\mathrm{H}}_{2}\right), 2.74$ (dddd, $J=16.4,10.8,9.0,1.5 \mathrm{~Hz}$, $\left.1 \mathrm{H}, 1 \times \mathrm{C} 5-\underline{\mathrm{H}}_{2}\right), 2.53\left(\mathrm{dddd}, J=12.4,9.0,7.6,2.1 \mathrm{~Hz}, 1 \mathrm{H}, 1 \times \mathrm{C} 6-\underline{\mathrm{H}}_{2}\right), 2.42(\mathrm{ddd}, J=16.4,9.4$, $\left.2.1 \mathrm{~Hz}, 1 \mathrm{H}, 1 \times \mathrm{C} 5-\underline{\mathrm{H}}_{2}\right), 1.98-1.89\left(\mathrm{~m}, 1 \mathrm{H}, 1 \times \mathrm{C} 6-\underline{\mathrm{H}}_{2}\right) ;{ }^{13} \mathrm{C} \mathrm{NMR}\left(\mathrm{CDCl}_{3}, 100 \mathrm{MHz}\right): \delta 175.5$ (C4), 141.9 (C1), 138.7 (C9), 127.9 (C10), 125.7 (C11), 122.7 (C12), 116.4 (C8), 64.7 (C7), 41.6 (C3), 34.0 (C5), 32.1 (C2), 27.9 (C6); HRMS: (ESI ${ }^{+}$) calculated for $\mathrm{C}_{12} \mathrm{H}_{14} \mathrm{NOS}$ : 220.0791, found $[\mathrm{M}+\mathrm{H}]^{+}: 220.0780$.

\section{$N$-(4-(Naphthalen-1-yl)but-3-yn-1-yl)cyclopropanamine 50}
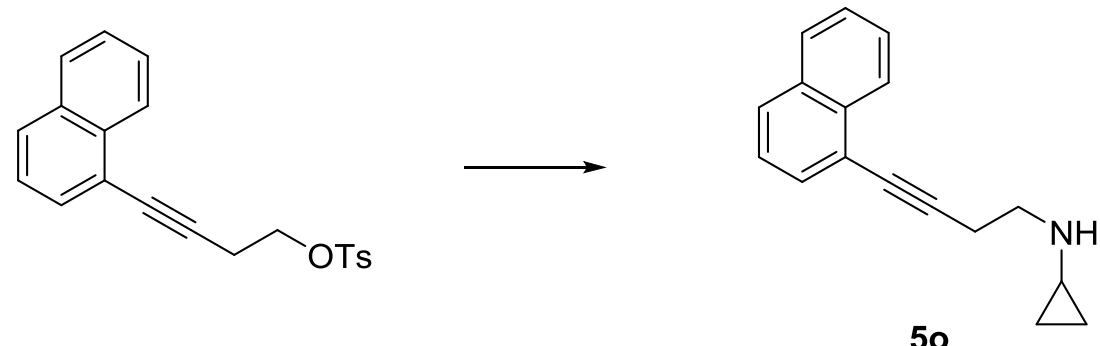

50

General procedure A: 4-(naphthalen-1-yl)but-3-yn-1-yl 4-methylbenzenesulfonate $(2.10 \mathrm{~g}, 6.00$ mmol, prepared according to the literature procedure ${ }^{12}$ ) was employed. The crude mixture was purified by flash column chromatography (30-40\% EtOAc/Hexane) to afford the title compound 5o $(0.70 \mathrm{~g}, 50 \%)$ as a pale yellow oil; $v_{\max } / \mathrm{cm}^{-1}: 3006(\mathrm{~m}), 2926(\mathrm{~m}), 2830(\mathrm{~m}), 1586(\mathrm{~m}), 1396$ 


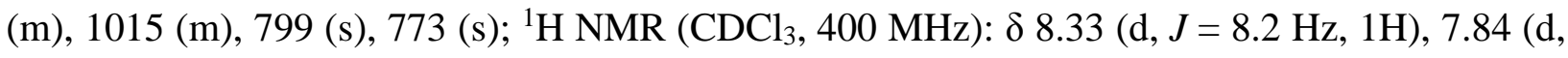
$J=7.9 \mathrm{~Hz}, 1 \mathrm{H}), 7.79(\mathrm{~d}, J=8.3 \mathrm{~Hz}, 1 \mathrm{H}), 7.64(\mathrm{~d}, J=7.1 \mathrm{~Hz}, 1 \mathrm{H}), 7.58-7.48(\mathrm{~m}, 2 \mathrm{H}), 7.40(\mathrm{t}, J$ $=7.7 \mathrm{~Hz}, 1 \mathrm{H}), 3.05(\mathrm{t}, J=6.6 \mathrm{~Hz}, 2 \mathrm{H}), 2.79(\mathrm{t}, J=6.6 \mathrm{~Hz}, 2 \mathrm{H}), 2.26(\mathrm{tt}, J=6.6,3.6 \mathrm{~Hz}, 1 \mathrm{H}), 1.85$ (br. s, $1 \mathrm{H}), 0.52-0.45(\mathrm{~m}, 2 \mathrm{H}), 0.44-0.38(\mathrm{~m}, 2 \mathrm{H}) ;{ }^{13} \mathrm{C} \mathrm{NMR}\left(\mathrm{CDCl}_{3}, 100 \mathrm{MHz}\right): \delta 133.6,133.3$, 130.3, 128.4, 128.3, 126.7, 126.4, 126.4, 125.3, 121.5, 93.3, 79.9, 48.2, 29.9, 21.0, 6.5; HRMS: $\left(\mathrm{ESI}^{+}\right)$calculated for $\mathrm{C}_{17} \mathrm{H}_{18} \mathrm{~N}: 236.1434$, found $[\mathrm{M}+\mathrm{H}]^{+}: 236.1428$.

\section{(E)-7-(Naphthalen-1-ylmethylene)hexahydro-3H-pyrrolizin-3-one 4o}

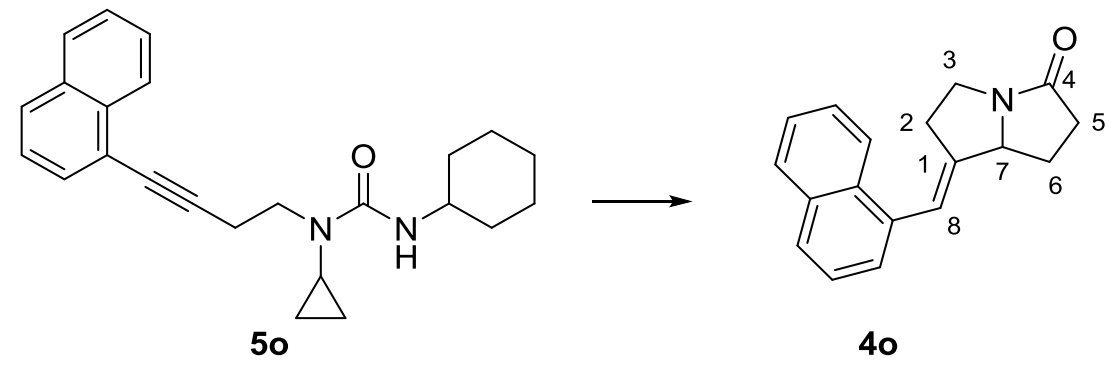

General procedure D: Compound $50(35.3 \mathrm{mg}, 0.15 \mathrm{mmol})$ and cyclohexyl isocyanate $(19 \mu \mathrm{L}$, $0.15 \mathrm{mmol}$ ) were employed. The crude mixture was purified by flash column chromatography (10\% Acetonitrile/ $\mathrm{CH}_{2} \mathrm{Cl}_{2}$ ) to afford the title compound $4 \mathrm{o}(21.3 \mathrm{mg}, 54 \%)$ as a pale brown oil; $v_{\max } / \mathrm{cm}^{-1}: 2928(\mathrm{~m}), 1692(\mathrm{~s}), 1412(\mathrm{~m}), 1395(\mathrm{~m}), 1280(\mathrm{~m}), 783(\mathrm{~s}) ;{ }^{1} \mathrm{H}$ NMR $\left(\mathrm{CDCl}_{3}, 500\right.$ $\mathrm{MHz}): \delta 7.97-7.94(\mathrm{~m}, 1 \mathrm{H}, 1 \times \mathrm{ArC} \underline{\mathrm{H}}), 7.89-7.85(\mathrm{~m}, 1 \mathrm{H}, 1 \times \mathrm{ArC} \underline{\mathrm{H}}), 7.78(\mathrm{~d}, J=8.4 \mathrm{~Hz}, 1 \mathrm{H}, 1$ $\times \mathrm{ArC} \underline{\mathrm{H}}), 7.55-7.43(\mathrm{~m}, 3 \mathrm{H}, 3 \times \mathrm{ArC} \underline{\mathrm{H}}), 7.39-7.35(\mathrm{~m}, 1 \mathrm{H}, 1 \times \mathrm{ArC} \underline{\mathrm{H}}), 6.93(\mathrm{~d}, J=2.5 \mathrm{~Hz}, 1 \mathrm{H}$, $1 \times \mathrm{C} 8-\underline{\mathrm{H}}), 4.69(\mathrm{td}, J=7.6,1.9 \mathrm{~Hz}, 1 \mathrm{H}, 1 \times \mathrm{C} 7-\underline{\mathrm{H}}), 3.94(\mathrm{dt}, J=12.1,6.2,6.0 \mathrm{~Hz}, 1 \mathrm{H}, 1 \times \mathrm{C} 3-$ $\left.\underline{\mathrm{H}}_{2}\right), 3.13-3.05\left(\mathrm{~m}, 1 \mathrm{H}, 1 \times \mathrm{C} 3-\underline{\mathrm{H}}_{2}\right), 2.86-2.75\left(\mathrm{~m}, 3 \mathrm{H}, 2 \times \mathrm{C} 2-\underline{\mathrm{H}}_{2}, 1 \times \mathrm{C} 5-\underline{\mathrm{H}}_{2}\right), 2.65$ (dddd, $J=$ 12.5, 9.0, 7.3, $\left.1.8 \mathrm{~Hz}, 1 \mathrm{H}, 1 \times \mathrm{C} 6-\underline{\mathrm{H}}_{2}\right), 2.51\left(\mathrm{ddd}, J=16.5,9.4,1.8 \mathrm{~Hz}, 1 \mathrm{H}, 1 \times \mathrm{C} 5-\mathrm{H}_{2}\right), 2.11$ (dddd, $\left.J=12.5,11.3,9.4,7.9 \mathrm{~Hz}, 1 \mathrm{H}, 1 \times \mathrm{C} 6-\underline{\mathrm{H}}_{2}\right) ;{ }^{13} \mathrm{C} \mathrm{NMR}\left(\mathrm{CDCl}_{3}, 126 \mathrm{MHz}\right): \delta 175.7(\mathrm{C4}), 145.1$, 134.1, 133.7, 131.7, 128.8, 127.9, 126.2, 126.1, 126.0, 126.0, 125.4 (10 × CAr, C1), 124.3 (C8), 119.8 (CAr), 64.6 (C7), 41.6 (C3), 34.3 (C5), 31.5 (C2), 28.3 (C6); HRMS: (ESI ${ }^{+}$) calculated for $\mathrm{C}_{18} \mathrm{H}_{18} \mathrm{NO}$ : 264.1383, found $[\mathrm{M}+\mathrm{H}]^{+}: 264.1385$. This compound is unstable and was stored as a frozen matrix in benzene. 


\section{$N$-((1-(Phenylethynyl)cyclopentyl)methyl)cyclopropanamine 5p}
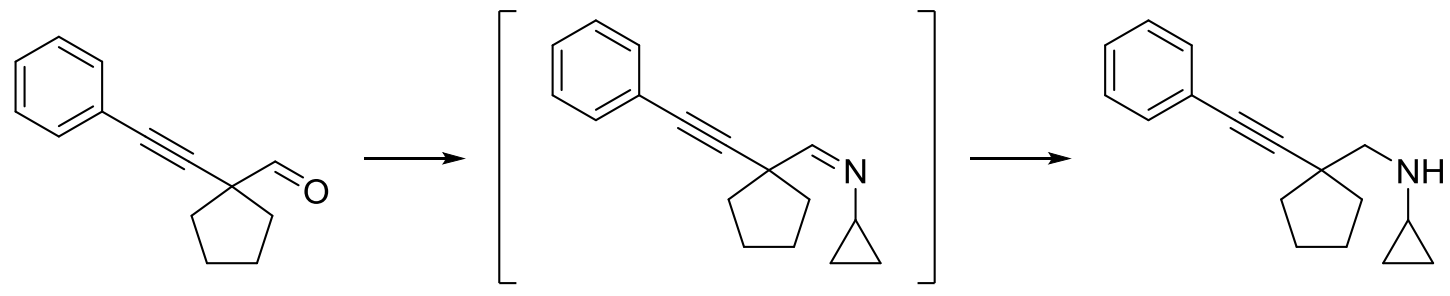

$5 p$

A solution of 1-(phenylethynyl)cyclopentane-1-carbaldehyde $(0.26 \mathrm{~g}, 1.31 \mathrm{mmol}$, prepared according to the literature procedure $\left.{ }^{15}\right)$, cyclopropylamine $(0.18 \mathrm{~mL}, 2.63 \mathrm{mmol})$ and $\mathrm{MgSO}_{4}(0.63$ $\mathrm{g}, 5.26 \mathrm{mmol})$ in $\mathrm{CH}_{2} \mathrm{Cl}_{2}(5.00 \mathrm{~mL})$ was stirred at room temperature for 16 hours. The mixture was filtered, rinsed with $\mathrm{CH}_{2} \mathrm{Cl}_{2}(2 \times 5 \mathrm{~mL})$ and concentrated in vacuo. The resulted imine was dissolved in $\mathrm{MeOH}(10.0 \mathrm{~mL})$, cooled to $0^{\circ} \mathrm{C}$ and then $\mathrm{NaBH}_{4}(74.3 \mathrm{mg}, 1.97 \mathrm{mmol})$ was added. The reaction was warmed up to room temperature, concentrated in vacuo, water $(20 \mathrm{~mL})$ was added and the solution was extracted with $\mathrm{CH}_{2} \mathrm{Cl}_{2}(3 \times 10 \mathrm{~mL})$. The organic extracts were combined, washed with brine $(20 \mathrm{~mL})$, dried over $\mathrm{MgSO}_{4}$ and concentrated in vacuo. The crude mixture was purified by flash column chromatography (0-10\% EtOAc/Hexane) to afford the title compound 5p (207 mg, 66\% over two steps) as a colorless oil; $v_{\max } / \mathrm{cm}^{-1}: 2954(\mathrm{~m}), 1491(\mathrm{~m})$, 1442 (m), 1014 (m), 754 (s), 691 (s); ${ }^{1} \mathrm{H}$ NMR (CDCl $\left.3,400 \mathrm{MHz}\right): \delta 7.41$ - 7.36 (m, 2H), 7.31 $7.24(\mathrm{~m}, 3 \mathrm{H}), 2.76(\mathrm{~s}, 2 \mathrm{H}), 2.23(\mathrm{tt}, J=6.6,3.6 \mathrm{~Hz}, 1 \mathrm{H}), 2.01-1.63(\mathrm{~m}, 8 \mathrm{H}), 0.47-0.32(\mathrm{~m}, 4 \mathrm{H})$; ${ }^{13} \mathrm{C} \mathrm{NMR}\left(\mathrm{CDCl}_{3}, 100 \mathrm{MHz}\right): \delta 131.7,128.3,127.6,124.1,96.4,81.5,58.5,44.1,38.9,31.0,24.8$, 6.7; HRMS: $\left(\mathrm{ESI}^{+}\right)$calculated for $\mathrm{C}_{17} \mathrm{H}_{22} \mathrm{~N}: 240.1747$, found $[\mathrm{M}+\mathrm{H}]^{+}: 240.1738$.

\section{(E)-1'-Benzylidenetetrahydro-3' $H, 5^{\prime} H$-spiro[cyclopentane-1,2'-pyrrolizin]-5'-one 4p}

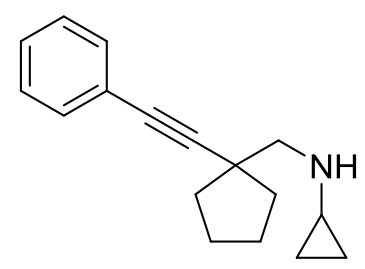

$5 p$

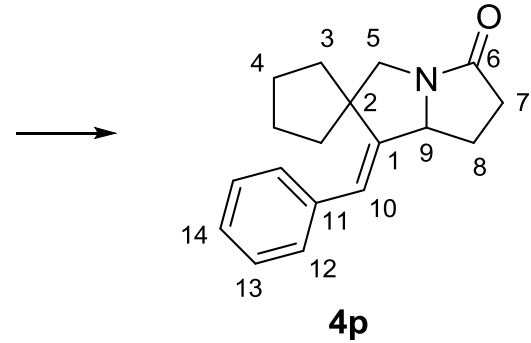

$4 p$

General procedure D: Compound $\mathbf{5 p}(35.9 \mathrm{mg}, 0.15 \mathrm{mmol})$ and cyclohexyl isocyanate $(19.0 \mu \mathrm{L}$, $0.15 \mathrm{mmol}$ ) were employed. The crude mixture was purified by flash column chromatography (10$20 \%$ Acetonitrile/ $\left.\mathrm{CH}_{2} \mathrm{Cl}_{2}\right)$ to afford the title compound $\mathbf{4 p}(29.8 \mathrm{mg}, 74 \%)$ as a colorless oil; $v_{\max }$ / $\mathrm{cm}^{-1}: 2939$ (m), $2870(\mathrm{~m}), 1690$ (s), 1448 (m), 1401 (s), 1281 (m), 1247 (m); ${ }^{1} \mathrm{H}$ NMR (CDCl 3 , $400 \mathrm{MHz}): \delta 7.34-7.27(\mathrm{~m}, 2 \mathrm{H}, 2 \times \mathrm{C} 12-\underline{\mathrm{H}}), 7.26-7.16(\mathrm{~m}, 3 \mathrm{H}, 1 \times \mathrm{C} 14-\underline{\mathrm{H}}, 2 \times \mathrm{C} 13-\underline{\mathrm{H}}), 6.44$ $(\mathrm{s}, 1 \mathrm{H}, 1 \times \mathrm{C10}-\underline{\mathrm{H}}), 4.59(\mathrm{td}, J=7.9,2.0 \mathrm{~Hz}, 1 \mathrm{H}, 1 \times \mathrm{C} 9-\underline{\mathrm{H}}), 3.80\left(\mathrm{~d}, J=11.2 \mathrm{~Hz}, 1 \mathrm{H}, 1 \times \mathrm{C} 5-\underline{\mathrm{H}}_{2}\right)$, 
$2.72\left(\mathrm{~d}, J=11.2 \mathrm{~Hz}, 1 \mathrm{H}, 1 \times \mathrm{C} 5-\underline{\mathrm{H}}_{2}\right), 2.78-2.65\left(\mathrm{~m}, 1 \mathrm{H}, 1 \times \mathrm{C} 7-\underline{\mathrm{H}}_{2}\right), 2.57-2.48(\mathrm{~m}, 1 \mathrm{H}, 1 \times \mathrm{C} 8-$ $\left.\underline{\mathrm{H}}_{2}\right), 2.44\left(\mathrm{ddd}, J=16.2,9.1,1.4 \mathrm{~Hz}, 1 \mathrm{H}, 1 \times \mathrm{C} 7-\underline{\mathrm{H}}_{2}\right), 1.98-1.81\left(\mathrm{~m}, 2 \mathrm{H}, 1 \times \mathrm{C} 8-\underline{\mathrm{H}}_{2}, 1 \times \mathrm{C} 3-\underline{\mathrm{H}}_{2}\right)$, $1.76-1.65\left(\mathrm{~m}, 3 \mathrm{H}, 2 \times \mathrm{C} 3-\underline{\mathrm{H}}_{2}, 1 \times \mathrm{C} 4-\underline{\mathrm{H}}_{2}\right), 1.63-1.35\left(\mathrm{~m}, 3 \mathrm{H}, 3 \times \mathrm{C} 4-\underline{\mathrm{H}}_{2}\right), 1.32-1.21(\mathrm{~m}, 1 \mathrm{H}$, $\left.1 \times \mathrm{C3}_{-} \mathrm{H}_{2}\right) ;{ }^{13} \mathrm{C} \mathrm{NMR}\left(\mathrm{CDCl}_{3}, 100 \mathrm{MHz}\right): \delta 176.2$ (C6), $151.5(\mathrm{C1}), 137.1$ (C11), $129.0(\mathrm{C13})$, 128.1 (C12), 127.0 (C14), 122.6 (C10), 66.4 (C9), 57.2 (C5), 55.8 (C2), 40.8 (C7), 34.0 (C3), 33.6 (C3'), 30.1 (C8), 25.5 (C4'), 25.4 (C4); HRMS: (ESI ${ }^{+}$) calculated for $\mathrm{C}_{18} \mathrm{H}_{22} \mathrm{NO}$ : 268.1696, found $[\mathrm{M}+\mathrm{H}]^{+}: 268.1698$.

\section{Scheme 4C:}

\section{Eqn 1:}

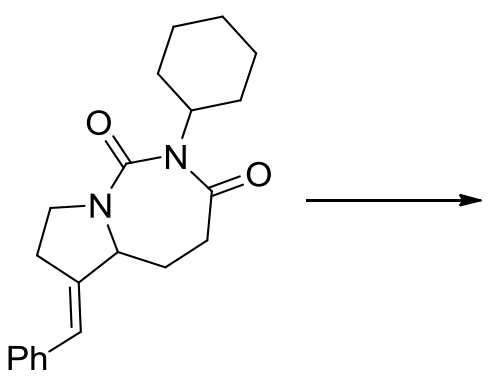

$3 \mathbf{k}$<smiles>O=C1CCC2/C(=C/c3ccccc3)CCN12</smiles>

4k<smiles>O=C(NC1CCCCC1)NC1CCCCC1</smiles>

7

To an oven dried reaction tube, fitted with a magnetic stirrer, was added $3 \mathbf{k}(58.7 \mathrm{mg}, 0.18 \mathrm{mmol})$ and anhydrous 1,2-DCB $(1.80 \mathrm{~mL})$ under argon. The mixture was then heated at $140{ }^{\circ} \mathrm{C}$ for 20 hours. The mixture was cooled to room temperature and concentrated in vacuo. The residue was purified by flash column chromatography (30-60\% EtOAc/Hexane) to afford the title compound 4k (34.0 mg, 90\%) as a yellow oil and compound 7 (13.8 mg, 70\%) as a colorless solid.

Data for compound 7: ${ }^{1} \mathrm{H}$ NMR $\left(500 \mathrm{MHz}, \mathrm{CDCl}_{3}\right): \delta 4.15-3.89(\mathrm{~d}, J=8.0 \mathrm{~Hz}, 2 \mathrm{H}), 3.51-3.44$ (m, 2H), $2.03-1.87(\mathrm{dd}, J=12.6,4.2 \mathrm{~Hz}, 4 \mathrm{H}), 1.77-1.59(\mathrm{~m}, 6 \mathrm{H}), 1.39-1.30(\mathrm{~m}, 4 \mathrm{H}), 1.18-$ $1.05(\mathrm{~m}, 6 \mathrm{H}) .{ }^{13} \mathrm{C} \mathrm{NMR}\left(126 \mathrm{MHz}, \mathrm{CDCl}_{3}\right): \delta 156.7,49.2,33.9,25.6,24.9$. The spectroscopic properties of this compound were consistent with the data available in the literature. ${ }^{16}$

\section{Eqn 2:}<smiles>O=C=NC1CCCCC1</smiles>

$5 k$<smiles>OCc1ccccc1</smiles><smiles>CCC</smiles>

$\mathrm{Ph}$<smiles>O=C(NC1CCCCC1)OCc1ccccc1</smiles>

4k
8 
To an oven dried reaction tube, fitted with a magnetic stirrer, was added 5k (18.5 mg, $0.10 \mathrm{mmol})$, cyclohexyl isocyanate $(12.8 \mu \mathrm{L}, 0.10 \mathrm{mmol})$ and anhydrous $1,2-\mathrm{DCB}(0.75 \mathrm{~mL})$ under argon. The mixture was then heated at $80{ }^{\circ} \mathrm{C}$ for 3 hours. The reaction was cooled to room temperature, $\left[\operatorname{Rh}(\operatorname{cod})_{2}\right] \mathrm{OTf}(3.52 \mathrm{mg}, \quad 7.50 \mu \mathrm{mol})$, triphenylphosphine $(3.93 \mathrm{mg}, 15.0 \mu \mathrm{mol}), 4-$ (dimethylamino)benzoic acid $(2.48 \mathrm{mg}, 15.0 \mu \mathrm{mol})$ and phenylmethanol $(16.2 \mathrm{mg}, 0.15 \mathrm{mmol})$ were added to the tube under argon. Anhydrous 1,2-DCB $(1.25 \mathrm{~mL})$ was then added by syringe. The reaction vessel was purged with $\mathrm{CO}$ for 10 minutes and the solution was subsequently sparged with $\mathrm{CO}$ for approximately 20 seconds. The mixture was then heated at the $130{ }^{\circ} \mathrm{C}$ for 72 hours, under a CO atmosphere (with CO balloon attached, $1 \mathrm{~atm}$ ). The mixture was cooled to room temperature and concentrated in vacuo. The residue was purified by flash column chromatography (20\% EtOAc/Hexane to $10 \%$ Acetonitrile/ $\mathrm{CH}_{2} \mathrm{Cl}_{2}$ ) to afford the compound $4 \mathbf{k}(13.3 \mathrm{mg}, 63 \%)$ as a yellow oil and compound $\mathbf{8}(22.0 \mathrm{mg}, 95 \%)$ as a colorless solid.

Data for compound 8: ${ }^{1} \mathrm{H}$ NMR (400 MHz, $\left.\mathrm{CDCl}_{3}\right)$ : $\delta 7.35-7.28(\mathrm{~m}, 5 \mathrm{H}), 5.07(\mathrm{~s}, 2 \mathrm{H}), 4.65$ (s, $1 \mathrm{H}, b r), 3.54-3.46(\mathrm{~m}, 1 \mathrm{H}), 1.94(\mathrm{~d}, J=10.0 \mathrm{~Hz}, 2 \mathrm{H}), 1.72-1.66(\mathrm{~m}, 2 \mathrm{H}), 1.59$ (dd, $J=9.2,3.8$ $\mathrm{Hz}, 1 \mathrm{H}), 1.39-1.25(\mathrm{~m}, 2 \mathrm{H}), 1.19-1.07$ (m, 3H); ${ }^{13} \mathrm{C} \mathrm{NMR}\left(100 \mathrm{MHz}, \mathrm{CDCl}_{3}\right): \delta 155.5,136.6$, 128.5, 128.1, 128.0, 66.4, 49.8, 33.4, 25.4, 24.7; The spectral data were consistent with those reported in the literatur. ${ }^{17}$ 


\section{Calculations}

\section{Computational Methods}

All calculations were performed in ORCA v. 4.1.1. Geometry optimizations were performed with the hybrid PBE0 functional, D3BJ dispersion correction, the def2-TZVP basis set. Optimization criteria were set to $\Delta E<1 \times 10^{-6}$ au and RMS(gradient) $<3 \times 10^{-5}$ au (TightOpt keyword). Vibrational frequencies were calculated at the same level of theory to assign stationary points as either minima or transition structures, as characterised by the presence of a zero or a single imaginary frequency respectively. Thermodynamic orrections were calculated at $150^{\circ} \mathrm{C}(423.15$ $\mathrm{K}$ ) using a $1 \mathrm{M}$ standard state using the quasi rigid rotor harmonic oscillator (q-RRHO) approximation. Solvent effects were accounted for with the SMD implicit solvent model using parameters appropriate for $o$-dichlorobenzene (DCB) at the single point level of theory. Single point energies were calculated using local pair natural orbital (DLPNO) coupled cluster up to perturbative triples [DLPNO-CCSD(T)] in conjunction with the larger def2-TZVPP basis set on all atoms and the default correlation auxiliary basis set (AutoAux keyword). The conformational space of minima were searched using the ETKDG algorithm implemented in RDKit then optimised at the density functional theory (DFT, PBE0-D3BJ/def2-SVP) level to locate global minima.

\section{Computational Analysis}

For computational efficiency and to reduce the conformational noise incurred when treating large benzyl substituents, the substrate 3aa was truncated to its dimethylated analogue (3a'). For the purposes of comparison, we do not expect this to have a significant effect on the obtained energetics due to the similar electronic and steric properties in the unencumbered reactants and TS.

Figure S1 outlines the free energy profile for the reaction with key distances highlighted. The energy barrier of $33.5 \mathrm{kcal} \mathrm{mol}^{-1}$ is consistent with the reaction conditions $\left(150^{\circ} \mathrm{C}, \sim 1\right.$ day). Furthermore, a tetrahedral intermediate that may be expected to form is not present in the potential energy surface; a tetrahedral intermediate with a fused 4-5 ring system is $>100 \mathrm{kcal} \mathrm{mol}^{-1}$ less stable than 3a' and is not a minimum. All other possibilities for transition states were higher in energy than TS1. The concerted intramolecular loss of isocyanate from the substrate is also consistent with the reaction being relatively unperturbed by the addition of acid or base. 
a.

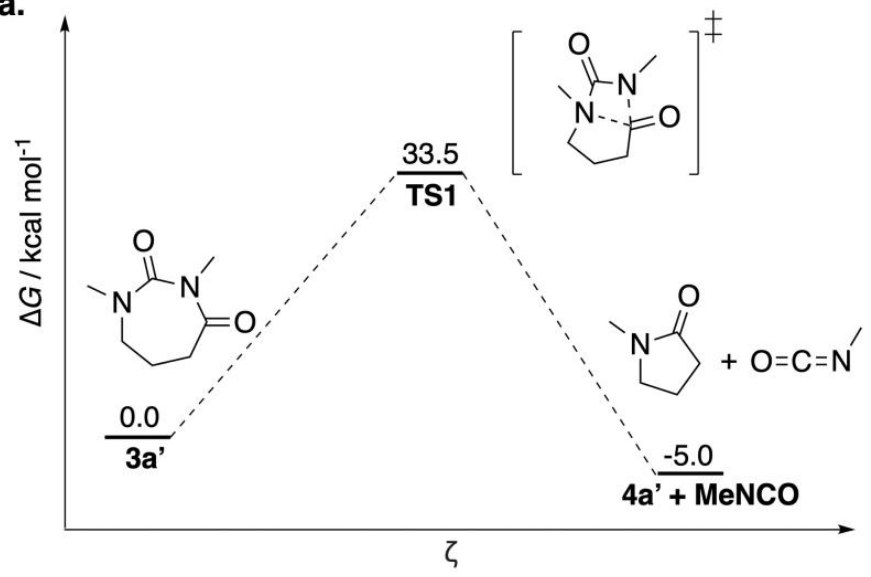

b.

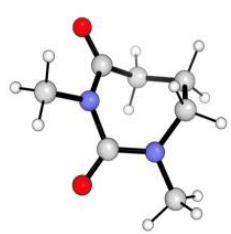

3a'

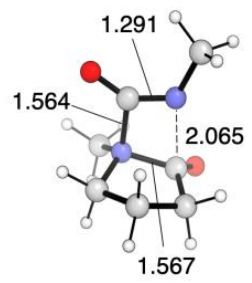

TS1

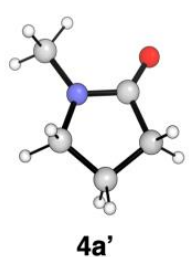

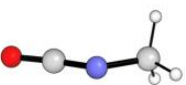

MeNCO

Figure S1. (a) Free energy profile computed at SMD(DCB)-DLPNO-CCSD(T)/def2-TZVPP//PBE0D3BJ/def2-TZVP, 423.15 K. (b) 3D geometries with key distances quoted in $\AA$.

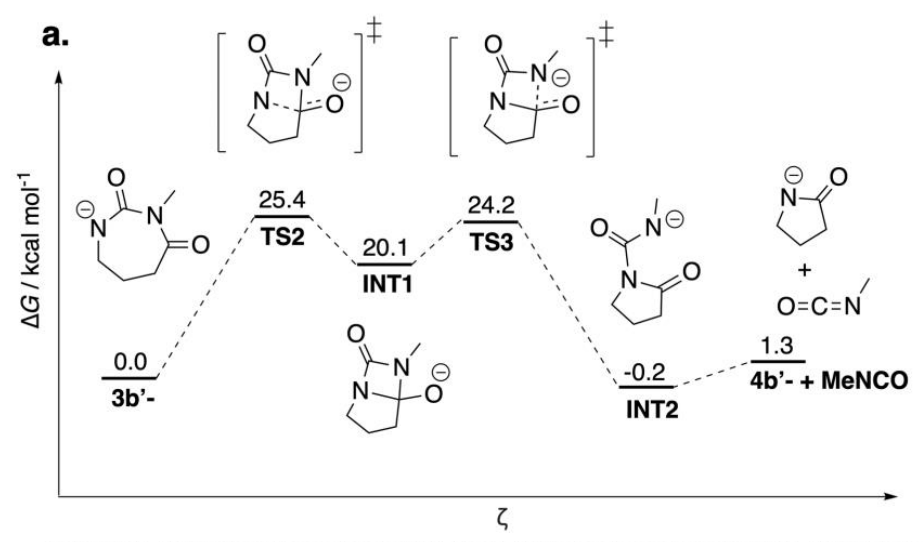

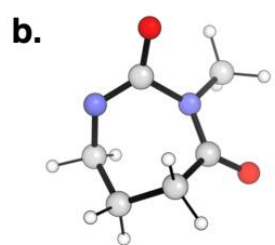

3b'-

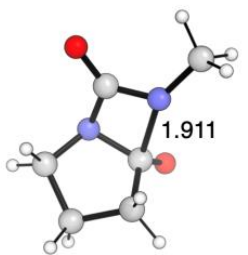

TS3

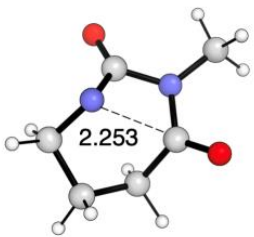

TS2

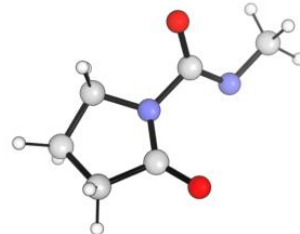

INT2

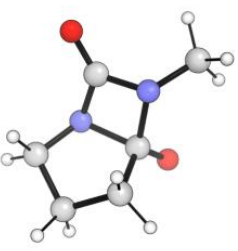

INT1

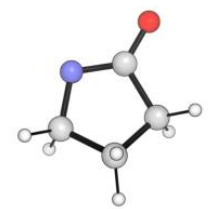

4b'-

Figure S2. (a) Free energy profile computed at SMD(DCB)-DLPNO-CCSD(T)/def2-TZVPP//PBE0D3BJ/def2-TZVP, $423.15 \mathrm{~K}$. (b) 3D geometries with key distances quoted in $\AA$.

Considering a truncated analogue of $\mathbf{3 b}, \mathbf{3} \mathbf{b}^{\prime}$ where (cyclohexyl $\rightarrow \mathrm{Me}$ ) under basic conditions, the substrate may be deprotonated to generate a sufficiently nucleophilic nitrogen to form a 
tetrahedral intermediate, which then collapses to give the ring contracted product upon loss of isocyanate (Figure S2). We note that using a naked anionic $\mathrm{N}$ is likely not representative of the reaction in solution in which hydrogen bond-donors or counterions likely increase its stability. However, due to the challenges in describing directional interactions and charge generation within a continuum solvent model we present the energetics without including these effects.

Due to the less nucleophilic nitrogen in 2aa the corresponding concerted transition state for the loss of isocyanate from the truncated analogue (2a') is $6.2 \mathrm{kcal} \mathrm{mol}^{-1}$ higher in energy than for $\mathbf{3 a}$ ', thus explaining why the unsaturated substrates do not undergo an analogous ring contraction (Figure S3). Likewise, the hydrogenic analogue of $\mathbf{3 b}, \mathbf{3 b}$ ' the barrier to thermal ring contraction renders it similarly inaccessible under non-basic reaction conditions (Figure S4).

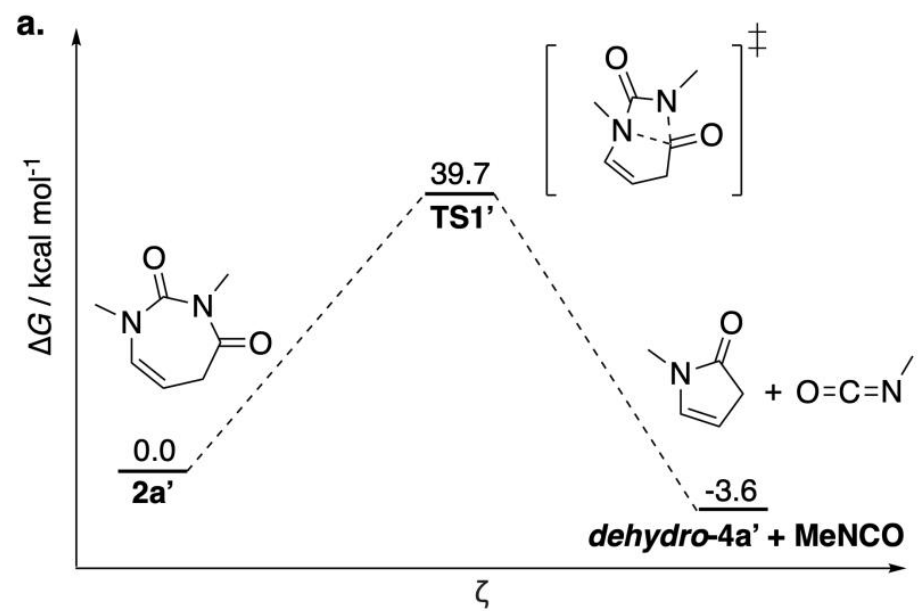

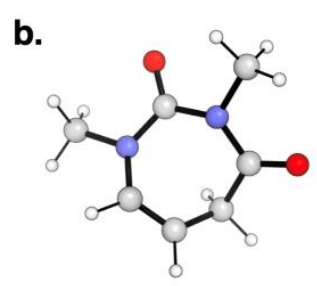

2a'

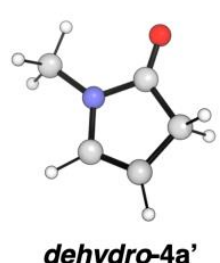

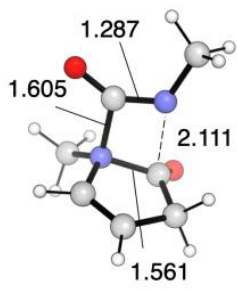

TS1'

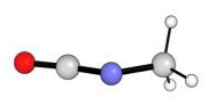

MeNCO

Figure S3. (a) Free energy profile computed at SMD(DCB)-DLPNO-CCSD(T)/def2-TZVPP//PBE0D3BJ/def2-TZVP, 423.15 K. (b) 3D geometries with key distances quoted in $\AA$.

a.

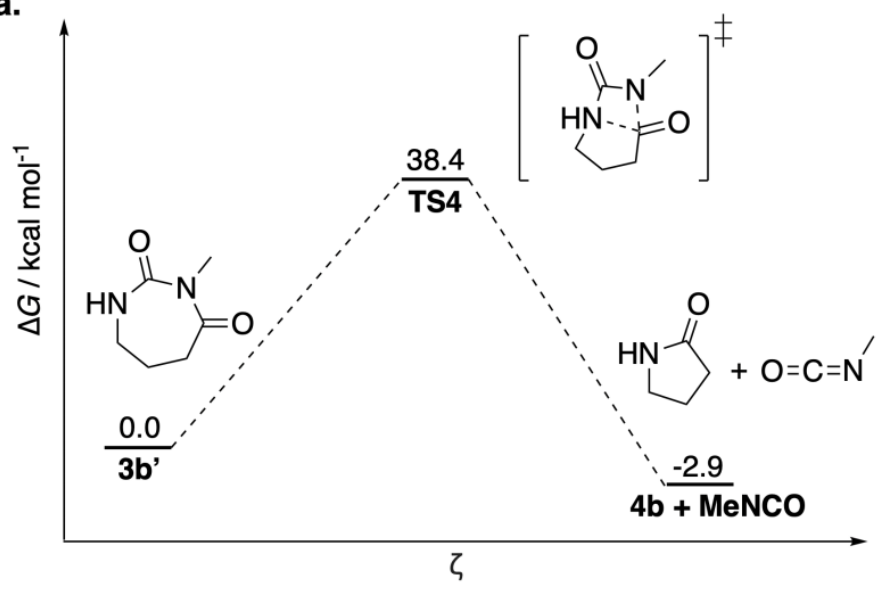

b.

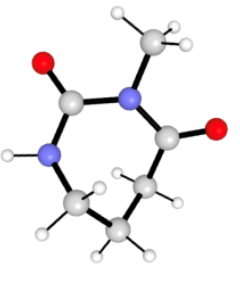

3b'

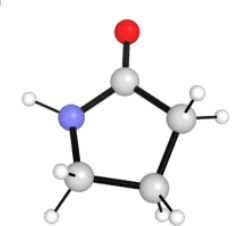

4b

Figure S4. (a) Free energy profile computed at SMD(DCB)-DLPNO-CCSD(T)/def2-TZVPP//PBE0D3BJ/def2-TZVP, 423.15 K. (b) 3D geometries with key distances quoted in $\AA$. 


\section{Cartesian Coordinates and Energies}

Cartesian coordinates and energies for species outlined in the manuscript. All energies are quoted in electronic Hartrees. Enthalpies and free energies are obtained directly from ORCA calculations at $298 \mathrm{~K}$ and do not include a $1 \mathrm{M}$ standard state correction.

Species: 3a'

$E(\mathrm{PBE} 0-\mathrm{D} 3 \mathrm{BJ} / \mathrm{def} 2-\mathrm{TZVP})=-533.57084931$

$G(\mathrm{PBE} 0-\mathrm{D} 3 \mathrm{BJ} / \mathrm{def} 2-\mathrm{TZVP}, 423.15 \mathrm{~K})=-533.42780235$

$E(\operatorname{SMD}(\mathrm{DCB})-\mathrm{DLPNO}-\mathrm{CCSD}(\mathrm{T}) / \mathrm{def} 2-\mathrm{TZVPP})=-533.10179962$

\begin{tabular}{llll}
$\mathrm{C}$ & 2.36138 & 1.73674 & -2.09986 \\
$\mathrm{C}$ & 2.77209 & -1.76943 & 1.19077 \\
$\mathrm{H}$ & 0.62455 & -2.44764 & 0.07460 \\
$\mathrm{H}$ & 0.58747 & -1.22795 & -1.18902 \\
$\mathrm{O}$ & 3.79604 & 0.40040 & -0.14604 \\
$\mathrm{C}$ & 2.61125 & 0.15844 & -0.24994 \\
$\mathrm{~N}$ & 1.75986 & 1.00674 & -0.99489 \\
$\mathrm{~N}$ & 2.01523 & -0.93680 & 0.28752 \\
$\mathrm{C}$ & 0.69233 & -1.37368 & -0.11053 \\
$\mathrm{C}$ & -0.40924 & -0.61584 & 0.61374 \\
$\mathrm{C}$ & -0.04995 & 0.86518 & 0.69243 \\
$\mathrm{C}$ & 0.49732 & 1.41449 & -0.60397 \\
$\mathrm{O}$ & -0.11574 & 2.21870 & -1.27161 \\
$\mathrm{H}$ & 1.72277 & 1.65276 & -2.97854 \\
$\mathrm{H}$ & 3.34269 & 1.31377 & -2.29240 \\
$\mathrm{H}$ & 2.46721 & 2.79469 & -1.85488 \\
$\mathrm{H}$ & 3.05877 & -2.71200 & 0.71338 \\
$\mathrm{H}$ & 2.18002 & -1.99553 & 2.08146 \\
$\mathrm{H}$ & 3.67652 & -1.24019 & 1.47970 \\
$\mathrm{H}$ & -0.55480 & -1.00395 & 1.62543 \\
$\mathrm{H}$ & -1.35170 & -0.75409 & 0.07738 \\
$\mathrm{H}$ & 0.69730 & 1.01482 & 1.47660 \\
$\mathrm{H}$ & -0.92190 & 1.46928 & 0.93772 \\
\hline
\end{tabular}


Species: TS1

\begin{tabular}{|c|c|c|c|}
\hline \multicolumn{4}{|c|}{$E(\mathrm{PBE} 0-\mathrm{D} 3 \mathrm{BJ} / \mathrm{def} 2-\mathrm{TZVP})=-533.51093382$} \\
\hline \multicolumn{4}{|c|}{$E(\mathrm{SMD}(\mathrm{DCB})-\mathrm{DLPNO}-\mathrm{CCSD}(\mathrm{T}) / \mathrm{def} 2-\mathrm{TZVPP})=-533.04674678$} \\
\hline \multicolumn{4}{|c|}{$\omega_{\text {imag }}=-134.62 \mathrm{~cm}^{-1}$} \\
\hline $\mathrm{C}$ & 2.15796 & 1.70623 & -2.38281 \\
\hline $\mathrm{C}$ & 2.96177 & -0.91376 & 1.31775 \\
\hline $\mathrm{H}$ & 0.55433 & -1.87747 & 1.37580 \\
\hline $\mathrm{H}$ & 1.05368 & -2.34433 & -0.26969 \\
\hline $\mathrm{O}$ & 2.97615 & -1.07603 & -1.60167 \\
\hline $\mathrm{C}$ & 2.36584 & -0.21821 & -1.00431 \\
\hline $\mathrm{N}$ & 1.92276 & 0.98433 & -1.16191 \\
\hline $\mathrm{N}$ & 1.85907 & -0.54177 & 0.43897 \\
\hline $\mathrm{C}$ & 0.75169 & -1.51076 & 0.36515 \\
\hline $\mathrm{C}$ & -0.42213 & -0.70336 & -0.17665 \\
\hline $\mathrm{C}$ & -0.27289 & 0.66072 & 0.48284 \\
\hline $\mathrm{C}$ & 1.20000 & 0.84126 & 0.76707 \\
\hline $\mathrm{O}$ & 1.72693 & 1.58486 & 1.53621 \\
\hline $\mathrm{H}$ & 2.51825 & 2.71240 & -2.15438 \\
\hline $\mathrm{H}$ & 1.23211 & 1.81038 & -2.95974 \\
\hline $\mathrm{H}$ & 2.89799 & 1.20348 & -3.01331 \\
\hline $\mathrm{H}$ & 3.52972 & -1.70532 & 0.82988 \\
\hline $\mathrm{H}$ & 2.57404 & -1.25010 & 2.27870 \\
\hline $\mathrm{H}$ & 3.58574 & -0.03393 & 1.46682 \\
\hline $\mathrm{H}$ & -1.36977 & -1.18651 & 0.06114 \\
\hline $\mathrm{H}$ & -0.34796 & -0.61898 & -1.26107 \\
\hline $\mathrm{H}$ & -0.77980 & 0.69421 & 1.45238 \\
\hline $\mathrm{H}$ & -0.64209 & 1.48936 & -0.11746 \\
\hline
\end{tabular}

Species: $\mathbf{4 a}^{\prime}$ 
$E(\mathrm{PBE} 0-\mathrm{D} 3 \mathrm{BJ} / \mathrm{def} 2-\mathrm{TZVP})=-325.70282124$

$G(\mathrm{PBE} 0-\mathrm{D} 3 \mathrm{BJ} / \mathrm{def} 2-\mathrm{TZVP}, 423.15 \mathrm{~K})=-325.60679184$

$E(\operatorname{SMD}(\mathrm{DCB})-\mathrm{DLPNO}-\mathrm{CCSD}(\mathrm{T}) / \mathrm{def} 2-\mathrm{TZVPP})=-325.40855216$
$\begin{array}{llll}\text { O } & 0.34568 & 2.35741 & -0.09738\end{array}$
$\begin{array}{llll}\text { C } & -0.07008 & 1.22103 & -0.03374\end{array}$
$\begin{array}{llll}\text { C } & -1.52071 & 0.77891 & -0.01743\end{array}$
$\begin{array}{llll}\text { C } & -1.46556 & -0.69085 & 0.38078\end{array}$
$\begin{array}{llll}\text { C } & -0.06052 & -1.12926 & -0.03878\end{array}$
$\begin{array}{llll}\mathrm{N} & 0.69655 & 0.09661 & 0.00652\end{array}$
$\begin{array}{llll}\text { C } & 2.11818 & 0.12672 & -0.16393\end{array}$
$\begin{array}{llll}\mathrm{H} & -1.91556 & 0.92082 & -1.02858\end{array}$
$\mathrm{H} \quad-2.10481 \quad 1.40980 \quad 0.65134$
$\mathrm{H} \quad-2.24152 \quad-1.29984 \quad-0.08209$
$\begin{array}{llll}\mathrm{H} & -1.56654 & -0.78743 & 1.46384\end{array}$
$\begin{array}{llll}\mathrm{H} & 0.36612 & -1.87598 & 0.63756\end{array}$
$\begin{array}{llll}\mathrm{H} & -0.04966 & -1.55858 & -1.05131\end{array}$
H $\quad 2.61981 \quad-0.42839 \quad 0.63398$
$\begin{array}{llll}\mathrm{H} & 2.43528 & 1.16857 & -0.13510\end{array}$
$\begin{array}{llll}\mathrm{H} & 2.41324 & -0.30943 & -1.12558\end{array}$

Species: MeNCO

$E(\mathrm{PBE} 0-\mathrm{D} 3 \mathrm{BJ} / \mathrm{def} 2-\mathrm{TZVP})=-207.83988045$

$G(\mathrm{PBE} 0-\mathrm{D} 3 \mathrm{BJ} / \mathrm{def} 2-\mathrm{TZVP}, 423.15 \mathrm{~K})=-207.82504145$

$E(\mathrm{SMD}(\mathrm{DCB})-\mathrm{DLPNO}-\mathrm{CCSD}(\mathrm{T}) / \mathrm{def} 2-\mathrm{TZVPP})=-207.66908425$
$\begin{array}{llll}\mathrm{O} & 2.70269 & 0.12454 & 0.11707\end{array}$
$\begin{array}{llll}\text { C } & 1.56360 & -0.05143 & -0.07708\end{array}$
$\mathrm{N} \quad 0.43525 \quad-0.31145 \quad-0.36914$
$\begin{array}{llll}\text { C } & -0.90536 & 0.00132 & 0.01139\end{array}$
$\mathrm{H} \quad-1.08613 \quad-0.25481 \quad 1.05800$
$\begin{array}{llll}\mathrm{H} & -1.11524 & 1.06378 & -0.13366\end{array}$ 
$\begin{array}{llll}\mathrm{H} & -1.59491 & -0.57197 & -0.60647\end{array}$

Species: 3b’-

$E(\mathrm{PBE} 0-\mathrm{D} 3 \mathrm{BJ} / \mathrm{def} 2-\mathrm{TZVP})=-493.72074467$

$G(\mathrm{PBE} 0-\mathrm{D} 3 \mathrm{BJ} / \mathrm{def} 2-\mathrm{TZVP}, 423.15 \mathrm{~K})=-493.61626312$

$E(\mathrm{SMD}(\mathrm{DCB})-\mathrm{DLPNO}-\mathrm{CCSD}(\mathrm{T}) / \mathrm{def} 2-\mathrm{TZVPP})=-493.35672574$

$\begin{array}{llll}\text { C } & 2.32621 & 1.66762 & -0.89532\end{array}$

H $\quad 0.26195 \quad-0.57996 \quad 1.63764$

H $\quad 0.87668 \quad-2.11943 \quad 0.99991$

H $\quad-1.65450 \quad-1.57602 \quad 0.70658$

$\mathrm{H} \quad-0.81203 \quad-2.13010 \quad-0.74687$

H $\quad-2.27261 \quad-0.06207 \quad-1.06738$

$\mathrm{H} \quad-0.61167 \quad 0.05232 \quad-1.63680$

$\begin{array}{llll}\text { O } & 2.50413 & -0.99577 & -0.49822\end{array}$

$\begin{array}{llll}\text { C } & 1.49652 & -0.42090 & -0.08430\end{array}$

$\begin{array}{llll}\mathrm{N} & 1.27557 & 0.89421 & -0.28468\end{array}$

$\begin{array}{llll}\text { C } & 0.44972 & -1.15385 & 0.72607\end{array}$

$\begin{array}{llll}\text { C } & -0.87462 & -1.31264 & -0.01709\end{array}$

$\begin{array}{llll}\text { C } & -1.23083 & -0.00506 & -0.72363\end{array}$

$\begin{array}{llll}\mathrm{N} & -1.08504 & 1.14842 & 0.11298\end{array}$

$\begin{array}{llll}\text { C } & 0.10709 & 1.64642 & 0.28783\end{array}$

$\begin{array}{llll}\text { O } & 0.42446 & 2.69559 & 0.86132\end{array}$

$\mathrm{H} \quad 2.33998 \quad 1.53362 \quad-1.98394$

H $3.30208 \quad 1.35764 \quad-0.51425$

$\begin{array}{llll}\mathrm{H} & 2.14031 & 2.71063 & -0.64397\end{array}$

Species: TS2

$E(\mathrm{PBE} 0-\mathrm{D} 3 \mathrm{BJ} / \mathrm{def} 2-\mathrm{TZVP})=-493.68228955$

$G(\mathrm{PBE} 0-\mathrm{D} 3 \mathrm{BJ} / \mathrm{def} 2-\mathrm{TZVP}, 423.15 \mathrm{~K})=-493.57918049$

$E(\mathrm{SMD}(\mathrm{DCB})-\mathrm{DLPNO}-\mathrm{CCSD}(\mathrm{T}) / \mathrm{def} 2-\mathrm{TZVPP})=-493.31492605$ 


\begin{tabular}{|c|c|c|c|}
\hline \multicolumn{4}{|c|}{$\omega_{\text {imag }}=-94.94 \mathrm{~cm}^{-1}$} \\
\hline $\mathrm{O}$ & 2.20947 & -1.36300 & 0.95934 \\
\hline $\mathrm{C}$ & 1.48822 & -0.83437 & 0.11045 \\
\hline $\mathrm{N}$ & 0.34111 & -1.23241 & -0.47049 \\
\hline $\mathrm{C}$ & -0.79756 & -1.39657 & 0.36397 \\
\hline $\mathrm{C}$ & -1.59678 & -0.10265 & 0.11547 \\
\hline $\mathrm{C}$ & -0.61402 & 1.06682 & 0.11421 \\
\hline $\mathrm{N}$ & 1.75147 & 0.44414 & -0.41416 \\
\hline $\mathrm{C}$ & 0.53817 & 0.96860 & -0.90707 \\
\hline $\mathrm{O}$ & 0.49271 & 1.59595 & -1.95508 \\
\hline $\mathrm{H}$ & -0.55369 & -1.48962 & 1.43819 \\
\hline $\mathrm{H}$ & -1.41360 & -2.27028 & 0.09745 \\
\hline $\mathrm{H}$ & -2.40060 & 0.05754 & 0.84985 \\
\hline $\mathrm{H}$ & -2.05976 & -0.16742 & -0.87577 \\
\hline $\mathrm{H}$ & -1.13827 & 2.00052 & -0.11352 \\
\hline $\mathrm{H}$ & -0.17269 & 1.16014 & 1.11374 \\
\hline $\mathrm{C}$ & 3.03950 & 0.95794 & -0.75470 \\
\hline $\mathrm{H}$ & 3.13747 & 2.01831 & -0.49398 \\
\hline $\mathrm{H}$ & 3.26118 & 0.85499 & -1.82520 \\
\hline $\mathrm{H}$ & 3.76913 & 0.38624 & -0.17827 \\
\hline
\end{tabular}

\section{Species: INT1}

$E(\mathrm{PBE} 0-\mathrm{D} 3 \mathrm{BJ} / \mathrm{def} 2-\mathrm{TZVP})=-493.69174413$

$G(\mathrm{PBE} 0-\mathrm{D} 3 \mathrm{BJ} / \mathrm{def} 2-\mathrm{TZVP}, 423.15 \mathrm{~K})=-493.58799622$

$E(\operatorname{SMD}(\mathrm{DCB})-\mathrm{DLPNO}-\mathrm{CCSD}(\mathrm{T}) / \mathrm{def} 2-\mathrm{TZVPP})=-493.32390993$
$\begin{array}{llll}\text { O } & -0.14907 & 2.81643 & -0.23001\end{array}$
$\begin{array}{llll}\text { C } & 0.36069 & 1.70853 & -0.24325\end{array}$
$\begin{array}{llll}\mathrm{N} & 0.00972 & 0.54763 & -0.92275\end{array}$
$\begin{array}{llll}\text { C } & -1.25379 & -0.11200 & -0.70370\end{array}$
$\begin{array}{llll}\text { C } & -0.85044 & -1.46155 & -0.08331\end{array}$
$\begin{array}{llll}\text { C } & 0.40234 & -1.13986 & 0.72245\end{array}$ 


$\begin{array}{lrrr}\mathrm{N} & 1.44122 & 1.19333 & 0.42021 \\ \mathrm{C} & 1.21466 & -0.20308 & -0.22128 \\ \mathrm{O} & 2.15556 & -0.69823 & -0.89443 \\ \mathrm{H} & -1.82427 & -0.24951 & -1.63077 \\ \mathrm{H} & -1.88640 & 0.46323 & -0.01233 \\ \mathrm{H} & -0.58913 & -2.16456 & -0.88106 \\ \mathrm{H} & -1.66325 & -1.90407 & 0.50176 \\ \mathrm{H} & 0.99728 & -2.02204 & 0.96380 \\ \mathrm{H} & 0.13615 & -0.61742 & 1.64753 \\ \mathrm{C} & 2.72510 & 1.80385 & 0.53704 \\ \mathrm{H} & 2.68764 & 2.83830 & 0.18284 \\ \mathrm{H} & 3.42418 & 1.22863 & -0.08561 \\ \mathrm{H} & 3.09655 & 1.80974 & 1.57050\end{array}$

Species: TS3

$E(\mathrm{PBE} 0-\mathrm{D} 3 \mathrm{BJ} / \mathrm{def} 2-\mathrm{TZVP})=-493.68394475$

$G(\mathrm{PBE} 0-\mathrm{D} 3 \mathrm{BJ} / \mathrm{def} 2-\mathrm{TZVP}, 423.15 \mathrm{~K})=-493.58149968$

$E(\mathrm{SMD}(\mathrm{DCB})-\mathrm{DLPNO}-\mathrm{CCSD}(\mathrm{T}) / \mathrm{def} 2-\mathrm{TZVPP})=-493.31608515$

$\omega_{\text {imag }}=-192.77 \mathrm{~cm}^{-1}$

$\begin{array}{llll}\mathrm{O} & 0.01803 & 2.74698 & -0.39667 \\ \mathrm{C} & 0.59469 & 1.66900 & -0.25848 \\ \mathrm{~N} & 0.27033 & 0.46843 & -0.94549 \\ \mathrm{C} & -1.06549 & -0.06504 & -0.75276 \\ \mathrm{C} & -0.86836 & -1.39373 & 0.00621 \\ \mathrm{C} & 0.45121 & -1.20539 & 0.74716 \\ \mathrm{~N} & 1.60281 & 1.27492 & 0.51169 \\ \mathrm{C} & 1.27456 & -0.42660 & -0.29407 \\ \mathrm{O} & 2.21080 & -0.93504 & -0.89572 \\ \mathrm{H} & -1.58526 & -0.22756 & -1.70426 \\ \mathrm{H} & -1.66687 & 0.64389 & -0.17071 \\ \mathrm{H} & -0.77282 & -2.21978 & -0.70606\end{array}$




$\begin{array}{llll}\mathrm{H} & -1.71500 & -1.61737 & 0.66146 \\ \mathrm{H} & 0.94908 & -2.14031 & 1.00600 \\ \mathrm{H} & 0.31234 & -0.59856 & 1.64352 \\ \mathrm{C} & 2.54392 & 2.18080 & 1.07680 \\ \mathrm{H} & 2.28037 & 3.21960 & 0.83499 \\ \mathrm{H} & 3.55824 & 1.98973 & 0.69372 \\ \mathrm{H} & 2.59719 & 2.09754 & 2.17347\end{array}$

Species: INT2

$E(\mathrm{PBE} 0-\mathrm{D} 3 \mathrm{BJ} / \mathrm{def} 2-\mathrm{TZVP})=-493.71330227$

$G(\mathrm{PBE} 0-\mathrm{D} 3 \mathrm{BJ} / \mathrm{def} 2-\mathrm{TZVP}, 423.15 \mathrm{~K})=-493.61183371$

$E(\mathrm{SMD}(\mathrm{DCB})-\mathrm{DLPNO}-\mathrm{CCSD}(\mathrm{T}) / \mathrm{def} 2-\mathrm{TZVPP})=-493.35409756$
O $\quad-0.30006 \quad 2.68594 \quad-0.11438$
$\begin{array}{llll}\text { C } & 0.67570 & 1.95492 & -0.38855\end{array}$
$\begin{array}{llll}\mathrm{N} & 0.41434 & 0.51922 & -0.19073\end{array}$
$\begin{array}{llll}\text { C } & -0.93592 & 0.06326 & -0.43567\end{array}$
$\begin{array}{llll}\text { C } & -0.81970 & -1.45606 & -0.36584\end{array}$
$\begin{array}{llll}\text { C } & 0.31063 & -1.65528 & 0.62727\end{array}$
$\mathrm{N} \quad 1.85542 \quad 2.21018 \quad-0.85566$
$\begin{array}{llll}\text { C } & 1.15373 & -0.38255 & 0.50206\end{array}$
$\begin{array}{llll}\text { O } & 2.25507 & -0.25936 & 0.99845\end{array}$
$\mathrm{H} \quad-1.28754 \quad 0.42560 \quad-1.40409$
$\mathrm{H} \quad-1.62265 \quad 0.46203 \quad 0.32126$
$\mathrm{H} \quad-0.52896 \quad-1.84670 \quad-1.34555$
$\begin{array}{llll}\mathrm{H} & -1.75842 & -1.93601 & -0.07799\end{array}$
$\begin{array}{llll}\mathrm{H} & 0.93170 & -2.53527 & 0.45461\end{array}$
$\begin{array}{llll}\mathrm{H} & -0.05223 & -1.70411 & 1.66017\end{array}$
$\begin{array}{llll}\text { C } & 2.09324 & 3.61889 & -1.01433\end{array}$
$\begin{array}{llll}\mathrm{H} & 3.10789 & 3.77730 & -1.39974\end{array}$
$\begin{array}{llll}\mathrm{H} & 2.00155 & 4.18125 & -0.07033\end{array}$
$\begin{array}{llll}\mathrm{H} & 1.38765 & 4.10213 & -1.71221\end{array}$ 
Species: 4b'-

\begin{tabular}{|c|c|c|c|}
\hline \multicolumn{4}{|c|}{$E(\mathrm{PBE} 0-\mathrm{D} 3 \mathrm{BJ} / \mathrm{def} 2-\mathrm{TZVP})=-285.82765405$} \\
\hline \multicolumn{4}{|c|}{$E(\mathrm{SMD}(\mathrm{DCB})-\mathrm{DLPNO}-\mathrm{CCSD}(\mathrm{T}) / \mathrm{def} 2-\mathrm{TZVPP})=-285.65343849$} \\
\hline $\mathrm{H}$ & 1.10185 & -1.51104 & 1.05883 \\
\hline $\mathrm{H}$ & 0.90983 & -1.99549 & -0.62886 \\
\hline $\mathrm{H}$ & -1.28176 & -1.45046 & 1.41281 \\
\hline $\mathrm{H}$ & -1.30670 & -2.69914 & 0.15831 \\
\hline $\mathrm{H}$ & -2.62746 & -0.30757 & -0.18706 \\
\hline $\mathrm{H}$ & -1.84221 & -1.09311 & -1.54907 \\
\hline $\mathrm{O}$ & 1.53660 & 0.75366 & -0.28842 \\
\hline $\mathrm{C}$ & 0.47635 & 0.10104 & -0.29007 \\
\hline $\mathrm{C}$ & 0.47513 & -1.38329 & 0.17284 \\
\hline $\mathrm{C}$ & -0.99865 & -1.66902 & 0.37625 \\
\hline $\mathrm{C}$ & -1.64114 & -0.62475 & -0.56138 \\
\hline$N$ & -0.73143 & 0.48096 & -0.66710 \\
\hline
\end{tabular}

Species: $\mathbf{2} \mathbf{a}^{\prime}$

$E(\mathrm{PBE} 0-\mathrm{D} 3 \mathrm{BJ} / \mathrm{def} 2-\mathrm{TZVP})=-532.34601478$

$G(\mathrm{PBE} 0-\mathrm{D} 3 \mathrm{BJ} / \mathrm{def} 2-\mathrm{TZVP}, 423.15 \mathrm{~K})=-532.22631156$

$E(\operatorname{SMD}(\mathrm{DCB})-\mathrm{DLPNO}-\mathrm{CCSD}(\mathrm{T}) / \mathrm{def} 2-\mathrm{TZVPP})=-531.87562798$

$\begin{array}{lrrr}\mathrm{C} & 2.33382 & 1.73911 & -2.06626 \\ \mathrm{C} & 2.96152 & -1.81010 & 1.00789 \\ \mathrm{O} & 3.73094 & 0.30604 & -0.31365 \\ \mathrm{C} & 2.52707 & 0.15804 & -0.26428 \\ \mathrm{~N} & 1.68249 & 1.03086 & -0.96999 \\ \mathrm{~N} & 1.98813 & -0.91464 & 0.40472 \\ \mathrm{C} & 0.66439 & -1.34891 & 0.34171 \\ \mathrm{C} & -0.37159 & -0.52693 & 0.44881 \\ \mathrm{C} & -0.14522 & 0.92817 & 0.67302\end{array}$




$\begin{array}{llll}\mathrm{C} & 0.45952 & 1.54650 & -0.56044 \\ \mathrm{O} & -0.07586 & 2.43871 & -1.17283 \\ \mathrm{H} & 1.56611 & 2.03666 & -2.77507 \\ \mathrm{H} & 3.05812 & 1.07582 & -2.53101 \\ \mathrm{H} & 2.85408 & 2.62956 & -1.70942 \\ \mathrm{H} & 3.55376 & -2.32598 & 0.24827 \\ \mathrm{H} & 2.42820 & -2.53521 & 1.62013 \\ \mathrm{H} & 3.64606 & -1.24268 & 1.63675 \\ \mathrm{H} & 0.55095 & 1.06687 & 1.50975 \\ \mathrm{H} & -1.06411 & 1.46816 & 0.88605 \\ \mathrm{H} & 0.54186 & -2.42029 & 0.21958 \\ \mathrm{H} & -1.37709 & -0.90789 & 0.32804\end{array}$

Species: TS1'

$E(\mathrm{PBE} 0-\mathrm{D} 3 \mathrm{BJ} / \mathrm{def} 2-\mathrm{TZVP})=-532.27455357$

G(PBE0-D3BJ/def2-TZVP, 423.15 K $)=-532.15776864$

$E(\mathrm{SMD}(\mathrm{DCB})-\mathrm{DLPNO}-\mathrm{CCSD}(\mathrm{T}) / \mathrm{def} 2-\mathrm{TZVPP})=-531.80945532$

$\omega_{\text {imag }}=-150.98 \mathrm{~cm}^{-1}$

$\begin{array}{llll}\text { C } & 2.18330 & 1.73687 & -2.43294\end{array}$

C $\quad 2.87662 \quad-0.99843 \quad 1.31688$

$\begin{array}{llll}\text { O } & 3.24706 & -0.93132 & -1.53083\end{array}$

$\begin{array}{llll}\text { C } & 2.46798 & -0.15349 & -1.03991\end{array}$

$\begin{array}{llll}\mathrm{N} & 1.89006 & 0.97752 & -1.24536\end{array}$

$\begin{array}{llll}\mathrm{N} & 1.84461 & -0.54038 & 0.38789\end{array}$

$\begin{array}{llll}\text { C } & 0.72973 & -1.42935 & 0.20652\end{array}$

$\begin{array}{llll}\text { C } & -0.43569 & -0.80241 & 0.23969\end{array}$

$\begin{array}{llll}\text { C } & -0.29421 & 0.65833 & 0.49720\end{array}$

$\begin{array}{llll}\text { C } & 1.19244 & 0.83324 & 0.74172\end{array}$

$\begin{array}{llll}\mathrm{O} & 1.74290 & 1.58357 & 1.48265\end{array}$

$\begin{array}{llll}\mathrm{H} & 2.46111 & 2.75832 & -2.15909\end{array}$

$\begin{array}{llll}\mathrm{H} & 1.30323 & 1.79609 & -3.08219\end{array}$ 


$\begin{array}{llll}\mathrm{H} & 3.00407 & 1.29571 & -3.00691 \\ \mathrm{H} & 3.47766 & -1.74653 & 0.80092 \\ \mathrm{H} & 2.41632 & -1.41312 & 2.21282 \\ \mathrm{H} & 3.49292 & -0.14059 & 1.58077 \\ \mathrm{H} & -0.84486 & 0.99125 & 1.38227 \\ \mathrm{H} & -0.60866 & 1.27111 & -0.34818 \\ \mathrm{H} & -1.38573 & -1.29832 & 0.09915 \\ \mathrm{H} & 0.94027 & -2.47335 & 0.02419\end{array}$

Species: dehyro-4a'

$E(\mathrm{PBE} 0-\mathrm{D} 3 \mathrm{BJ} / \mathrm{def} 2-\mathrm{TZVP})=-324.47475088$

$G(\mathrm{PBE} 0-\mathrm{D} 3 \mathrm{BJ} / \mathrm{def} 2-\mathrm{TZVP}, 423.15 \mathrm{~K})=-324.40255948$

$E(\mathrm{SMD}(\mathrm{DCB})-\mathrm{DLPNO}-\mathrm{CCSD}(\mathrm{T}) / \mathrm{def} 2-\mathrm{TZVPP})=-324.17967139$

$\begin{array}{lrrr}\mathrm{C} & 2.92304 & -0.82242 & 1.58065 \\ \mathrm{~N} & 1.63624 & -0.52738 & 1.01923 \\ \mathrm{C} & 0.68358 & -1.46607 & 0.61994 \\ \mathrm{C} & -0.41262 & -0.88187 & 0.13654 \\ \mathrm{C} & -0.21429 & 0.59801 & 0.20131 \\ \mathrm{C} & 1.17568 & 0.75133 & 0.80134 \\ \mathrm{O} & 1.78042 & 1.76855 & 1.04884 \\ \mathrm{H} & 3.53937 & -1.39414 & 0.88097 \\ \mathrm{H} & 2.82843 & -1.38637 & 2.51257 \\ \mathrm{H} & 3.41175 & 0.12879 & 1.78869 \\ \mathrm{H} & -0.93990 & 1.11469 & 0.83667 \\ \mathrm{H} & -0.24203 & 1.09226 & -0.77424 \\ \mathrm{H} & -1.28897 & -1.38754 & -0.23596 \\ \mathrm{H} & 0.90268 & -2.51900 & 0.73049\end{array}$

Species: 3b'

$E(\mathrm{PBE} 0-\mathrm{D} 3 \mathrm{BJ} / \mathrm{def} 2-\mathrm{TZVP})=-494.29764827$ 
$G(\mathrm{PBE} 0-\mathrm{D} 3 \mathrm{BJ} / \mathrm{def} 2-\mathrm{TZVP}, 423.15 \mathrm{~K})=-494.18360634$

$E(\mathrm{SMD}(\mathrm{DCB})-\mathrm{DLPNO}-\mathrm{CCSD}(\mathrm{T}) / \mathrm{def} 2-\mathrm{TZVPP})=-493.87089589$

\begin{tabular}{|c|c|c|c|}
\hline 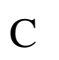 & 2.37540 & 1.78153 & -2.08349 \\
\hline $\mathrm{H}$ & 2.63962 & -1.53516 & 0.7604 \\
\hline 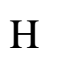 & 0.63110 & -2.46175 & 0.1964 \\
\hline $\mathrm{H}$ & 0.56675 & -1.33996 & -1.1532 \\
\hline C & 3.81902 & 0.29179 & -0.2596 \\
\hline $\mathrm{C}$ & 2.61762 & 0.13790 & -0.2946 \\
\hline $\mathrm{N}$ & 1.77798 & 1.02795 & $-0.991 \xi$ \\
\hline I & 1.99607 & -0.91655 & 0.297 \\
\hline$C$ & 0.68261 & -1.40431 & -0.066 \\
\hline $\mathrm{C}$ & -0.42647 & -0.61464 & 0.6123 \\
\hline$C$ & -0.05174 & 0.86232 & 0.6820 \\
\hline $\mathrm{C}$ & 0.50083 & 1.41125 & -0.6110 \\
\hline $\mathrm{O}$ & -0.11287 & 2.21042 & -1.282 \\
\hline $\mathrm{H}$ & 1.75653 & 1.68287 & -2.974 \\
\hline $\mathrm{H}$ & 3.37290 & 1.39014 & -2.257 \\
\hline $\mathrm{H}$ & 2.43972 & 2.84052 & -1.8296 \\
\hline $\mathrm{H}$ & -0.59928 & -0.98132 & 1.62 \\
\hline $\mathrm{H}$ & -1.35750 & -0.74819 & 0.055 \\
\hline $\mathrm{H}$ & 0.69528 & 1.00370 & 1.4674 \\
\hline $\mathrm{H}$ & -0.92013 & 1.47313 & 0.9 \\
\hline
\end{tabular}

Species: TS4

$E(\mathrm{PBE} 0-\mathrm{D} 3 \mathrm{BJ} / \mathrm{def} 2-\mathrm{TZVP})=-494.23016895$

$G(\mathrm{PBE} 0-\mathrm{D} 3 \mathrm{BJ} / \mathrm{def} 2-\mathrm{TZVP}, 423.15 \mathrm{~K})=-494.11827927$

$E(\mathrm{SMD}(\mathrm{DCB})-\mathrm{DLPNO}-\mathrm{CCSD}(\mathrm{T}) / \mathrm{def} 2-\mathrm{TZVPP})=-493.80747429$

$\omega_{\text {imag }}=-161.60 \mathrm{~cm}^{-1}$

$\begin{array}{llll}\text { C } & 2.16944 & 1.72897 & -2.36738\end{array}$

$\mathrm{H} \quad 2.60314 \quad-0.77165 \quad 1.03605$ 


$\begin{array}{lrrr}\mathrm{H} & 0.57032 & -1.88339 & 1.39426 \\ \mathrm{H} & 1.03658 & -2.37720 & -0.25384 \\ \mathrm{O} & 2.97622 & -1.08787 & -1.63484 \\ \mathrm{C} & 2.37455 & -0.23346 & -1.02776 \\ \mathrm{~N} & 1.93335 & 0.97488 & -1.16763 \\ \mathrm{~N} & 1.84291 & -0.55135 & 0.39802 \\ \mathrm{C} & 0.75015 & -1.53429 & 0.37540 \\ \mathrm{C} & -0.43120 & -0.72822 & -0.16207 \\ \mathrm{C} & -0.26815 & 0.65260 & 0.46182 \\ \mathrm{C} & 1.21196 & 0.83682 & 0.72496 \\ \mathrm{O} & 1.74787 & 1.56038 & 1.50991 \\ \mathrm{H} & 2.59207 & 2.70537 & -2.11700 \\ \mathrm{H} & 1.23272 & 1.90223 & -2.90792 \\ \mathrm{H} & 2.86098 & 1.20910 & -3.03764 \\ \mathrm{H} & -1.37759 & -1.20175 & 0.09801 \\ \mathrm{H} & -0.37142 & -0.66911 & -1.24945 \\ \mathrm{H} & -0.76288 & 0.71319 & 1.43585 \\ \mathrm{H} & -0.64439 & 1.46401 & -0.15742\end{array}$

Species: $\mathbf{4 b}$

$E(\mathrm{PBE} 0-\mathrm{D} 3 \mathrm{BJ} / \mathrm{def} 2-\mathrm{TZVP})=-286.42519404$

$G(\mathrm{PBE} 0-\mathrm{D} 3 \mathrm{BJ} / \mathrm{def} 2-\mathrm{TZVP}, 423.15 \mathrm{~K})=-286.35803595$

$E(\operatorname{SMD}(\mathrm{DCB})-\mathrm{DLPNO}-\mathrm{CCSD}(\mathrm{T}) / \mathrm{def} 2-\mathrm{TZVPP})=-286.17445331$
$\begin{array}{llll}\text { O } & 0.35499 & 2.35619 & -0.09137\end{array}$
$\begin{array}{llll}\text { C } & -0.06389 & 1.22415 & -0.02434\end{array}$
$\begin{array}{llll}\text { C } & -1.51607 & 0.77644 & -0.02319\end{array}$
$\begin{array}{llll}\text { C } & -1.46033 & -0.69101 & 0.38601\end{array}$
$\begin{array}{llll}\text { C } & -0.05644 & -1.13671 & -0.03891\end{array}$
$\begin{array}{llll}\mathrm{N} & 0.69278 & 0.09444 & 0.04190\end{array}$
$\begin{array}{llll}\mathrm{H} & 1.68727 & 0.14986 & -0.10004\end{array}$
$\begin{array}{llll}\mathrm{H} & -1.89663 & 0.90867 & -1.04101\end{array}$ 


$\begin{array}{llll}\mathrm{H} & -2.11074 & 1.41031 & 0.63310 \\ \mathrm{H} & -2.23953 & -1.30394 & -0.06625 \\ \mathrm{H} & -1.55252 & -0.77758 & 1.47090 \\ \mathrm{H} & 0.35560 & -1.90035 & 0.62445 \\ \mathrm{H} & -0.05792 & -1.54142 & -1.05946\end{array}$


Copies of ${ }^{1} \mathrm{H}$ and ${ }^{13} \mathrm{C}$ NMR Spectra for Novel Compounds

1-Benzyl-3-cyclohexyl-1-cyclopropylthiourea 1ad ${ }^{1} \mathrm{H}$ NMR and ${ }^{13} \mathrm{C} \mathrm{NMR} \mathrm{in} \mathrm{CDCl}_{3}$

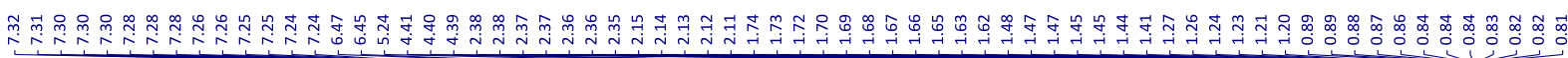

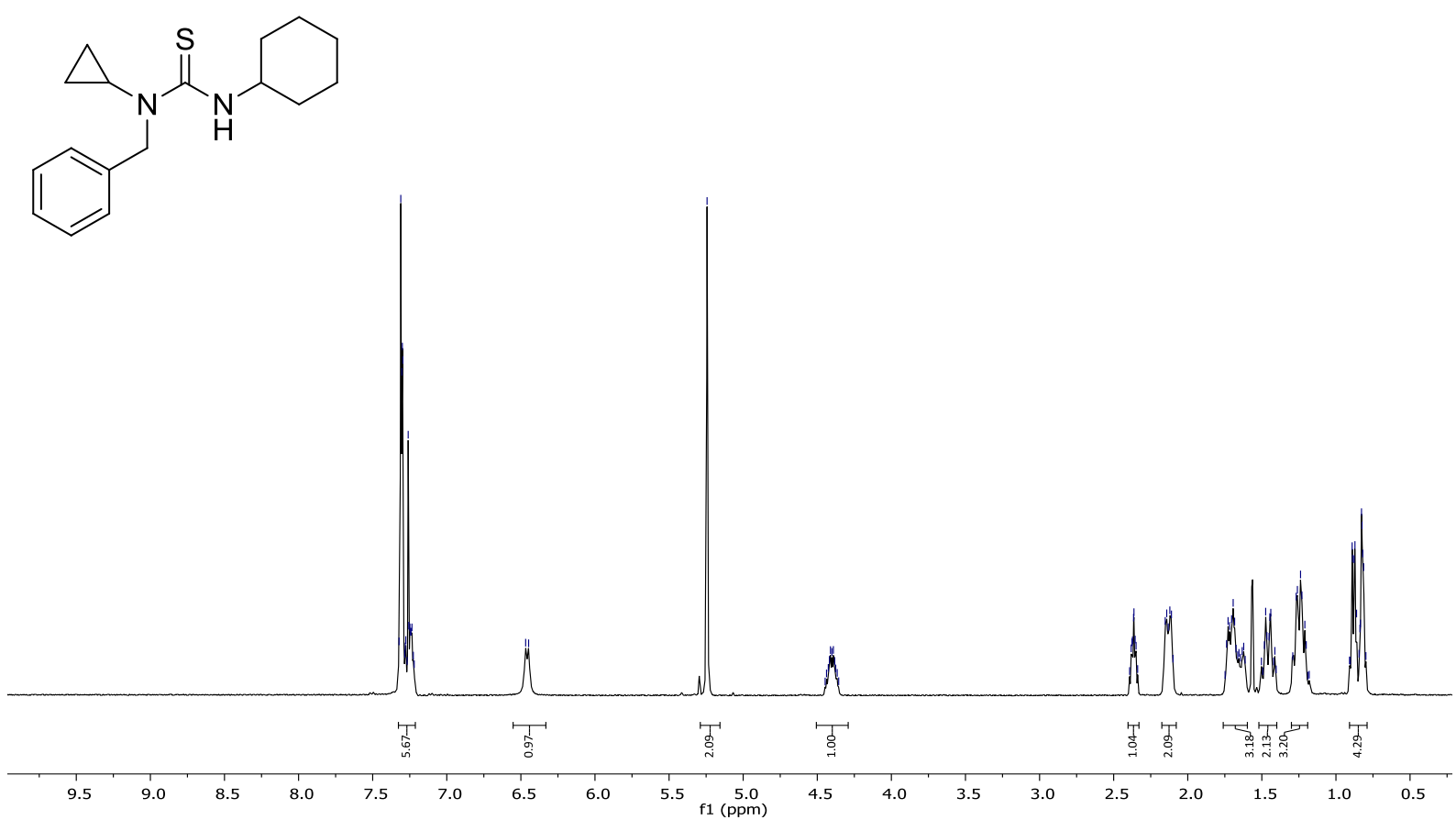

至

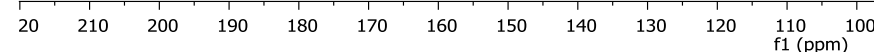


1-Benzyl-4-butylpyrrolidin-2-one 4d ${ }^{1} \mathrm{H} \mathrm{NMR}$ and ${ }^{13} \mathrm{C} \mathrm{NMR} \mathrm{in} \mathrm{CDCl}_{3}$

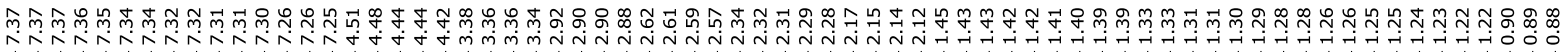

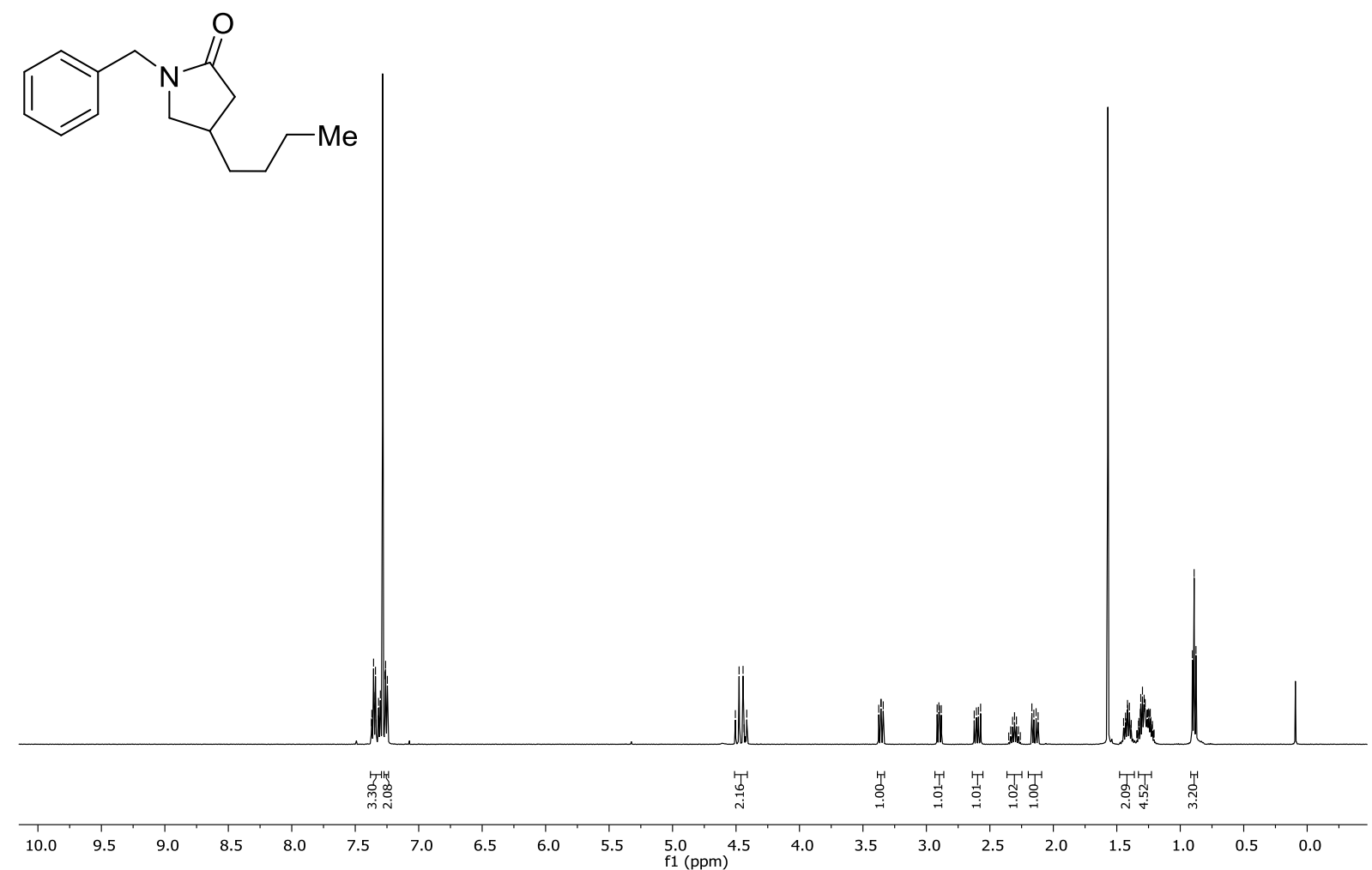

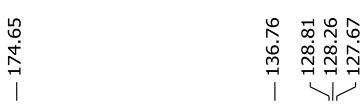
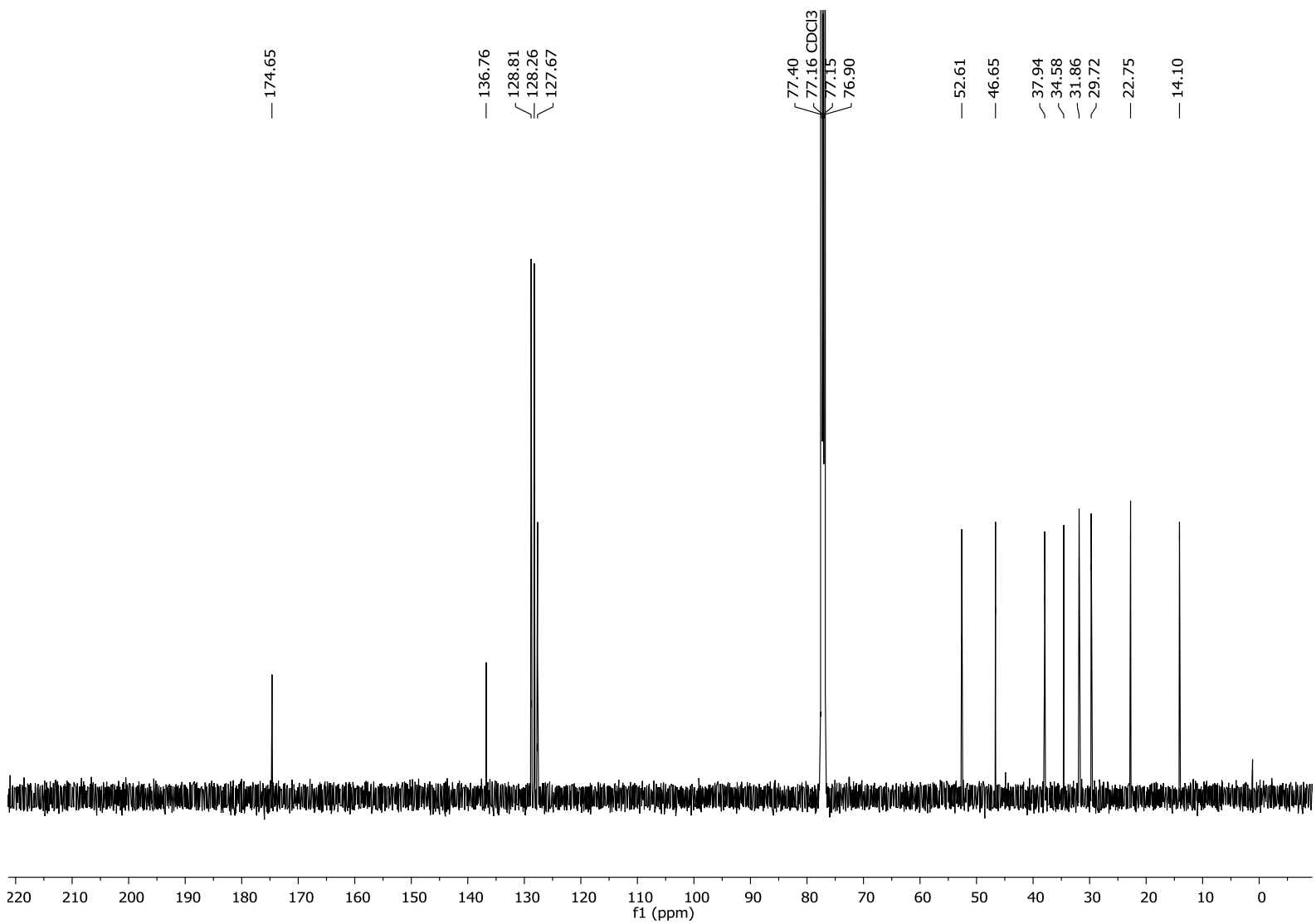
<smiles>O=C1CCC2c3sccc3CCN12</smiles>
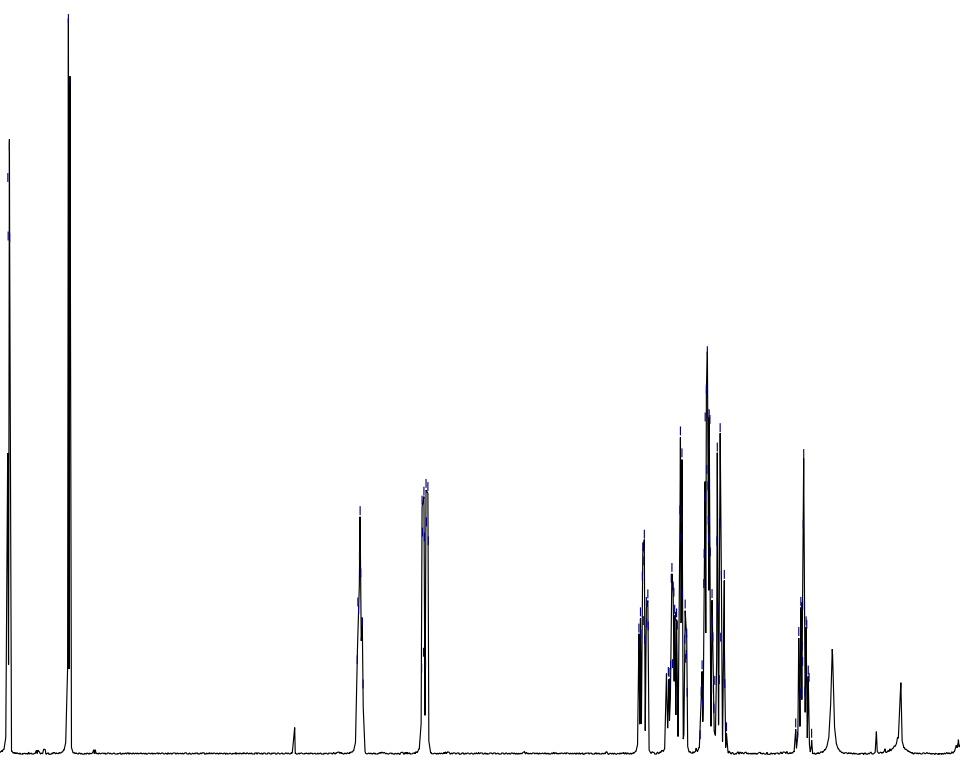

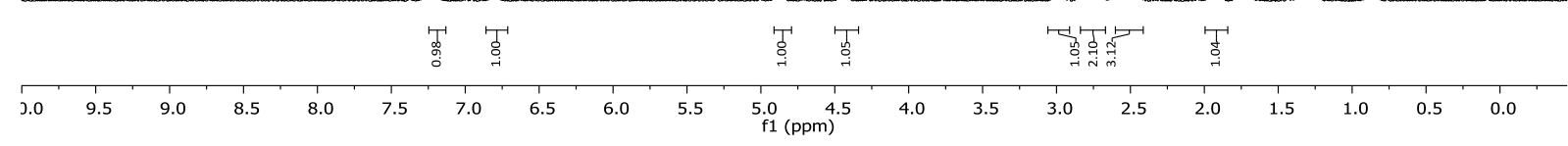

垔

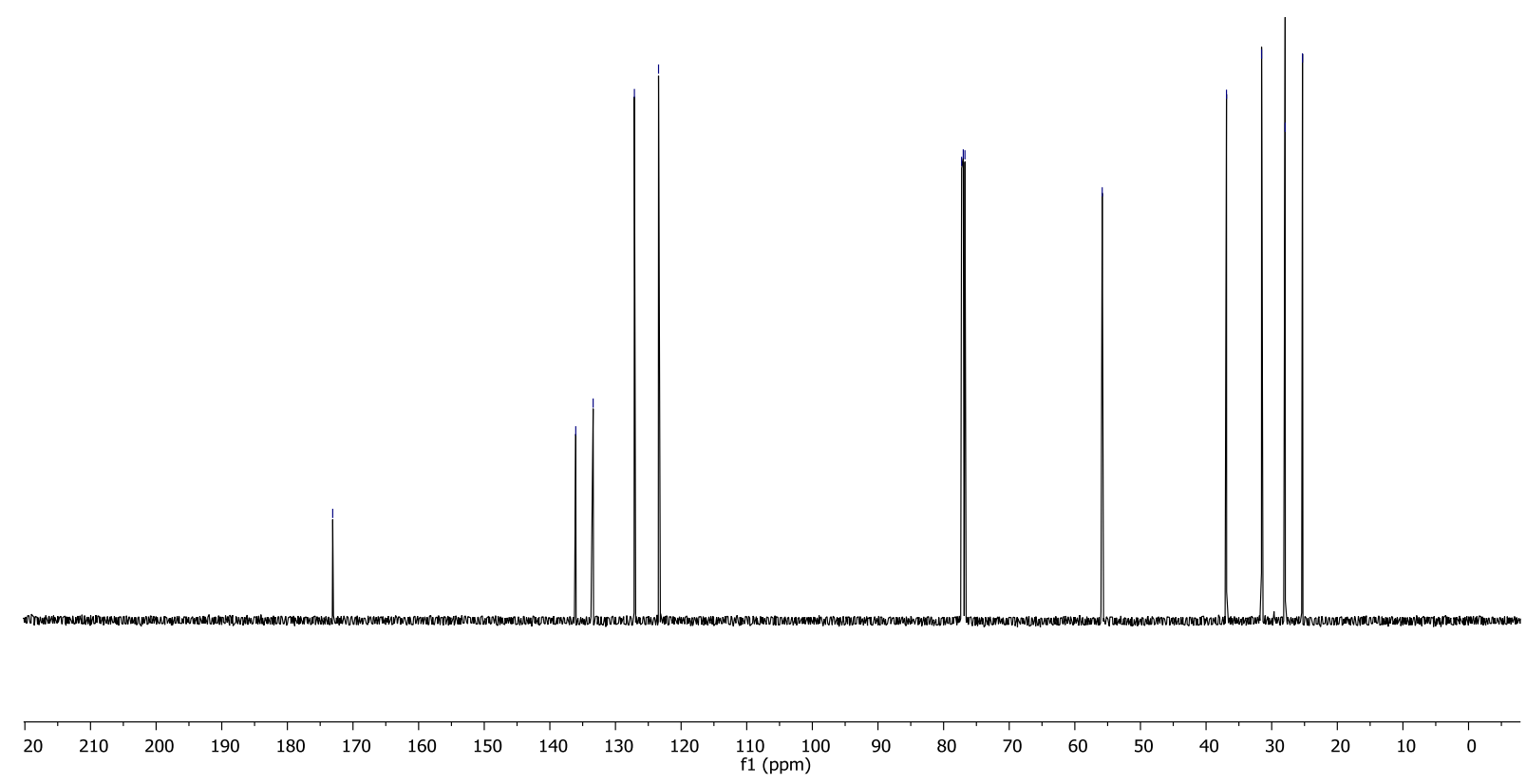


8,9-Dimethoxy-1,5,6,10b-tetrahydropyrrolo[2,1-a]isoquinolin-3(2H)-one $4 \mathbf{f ~}^{1} \mathrm{H}$ NMR and ${ }^{13} \mathrm{C}$ $\mathrm{NMR}$ in $\mathrm{CDCl}_{3}$

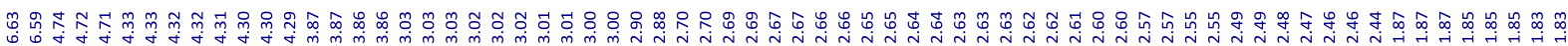<smiles>COc1cc2c(cc1OC)C1CCC(=O)N1CC2</smiles>
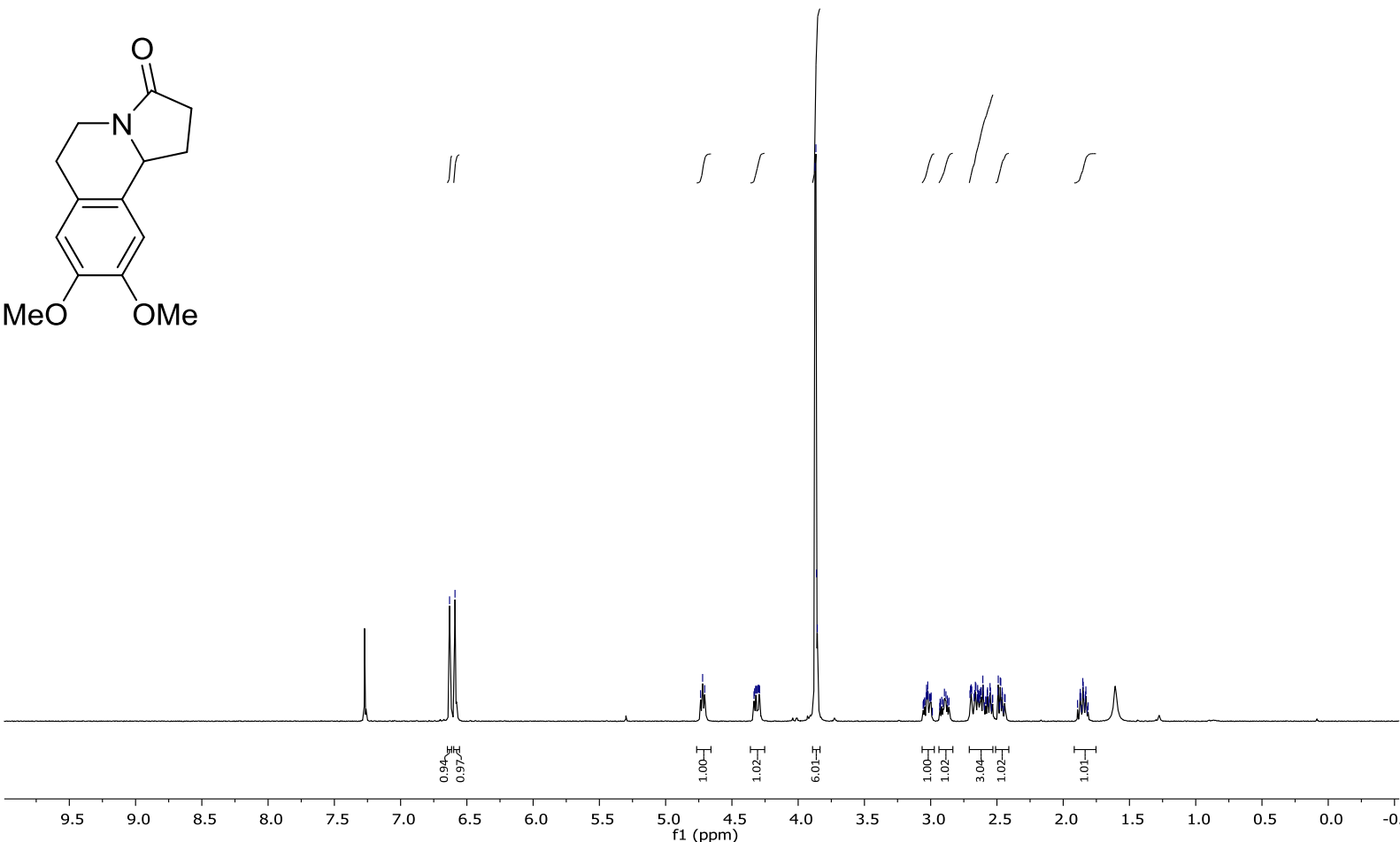

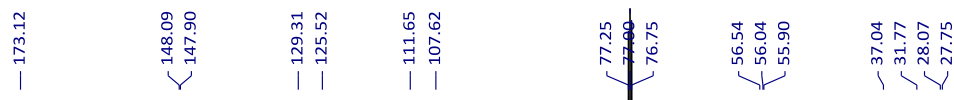

$\begin{array}{lllllllllllllllllllllllll}230 & 220 & 210 & 200 & 190 & 180 & 170 & 160 & 150 & 140 & 130 & 120 & \begin{array}{c}110 \\ \mathrm{f} 1(\mathrm{ppm})\end{array} & 100 & 90 & 80 & 70 & 60 & 50 & 40 & 30 & 20 & 10 & 0 & -10\end{array}$ 
3-Benzyl-1-((1S,2S)-2-methylcyclopropyl)-1-(2-(thiophen-3-yl)ethyl)urea and 3-Benzyl-1((1R,2S)-2-methylcyclopropyl)-1-(2-(thiophen-3-yl)ethyl)urea $1 \mathrm{~g}{ }^{1} \mathrm{H}$ NMR and ${ }^{13} \mathrm{C}$ NMR in $\mathrm{CDCl}_{3}$

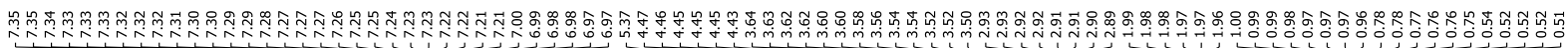
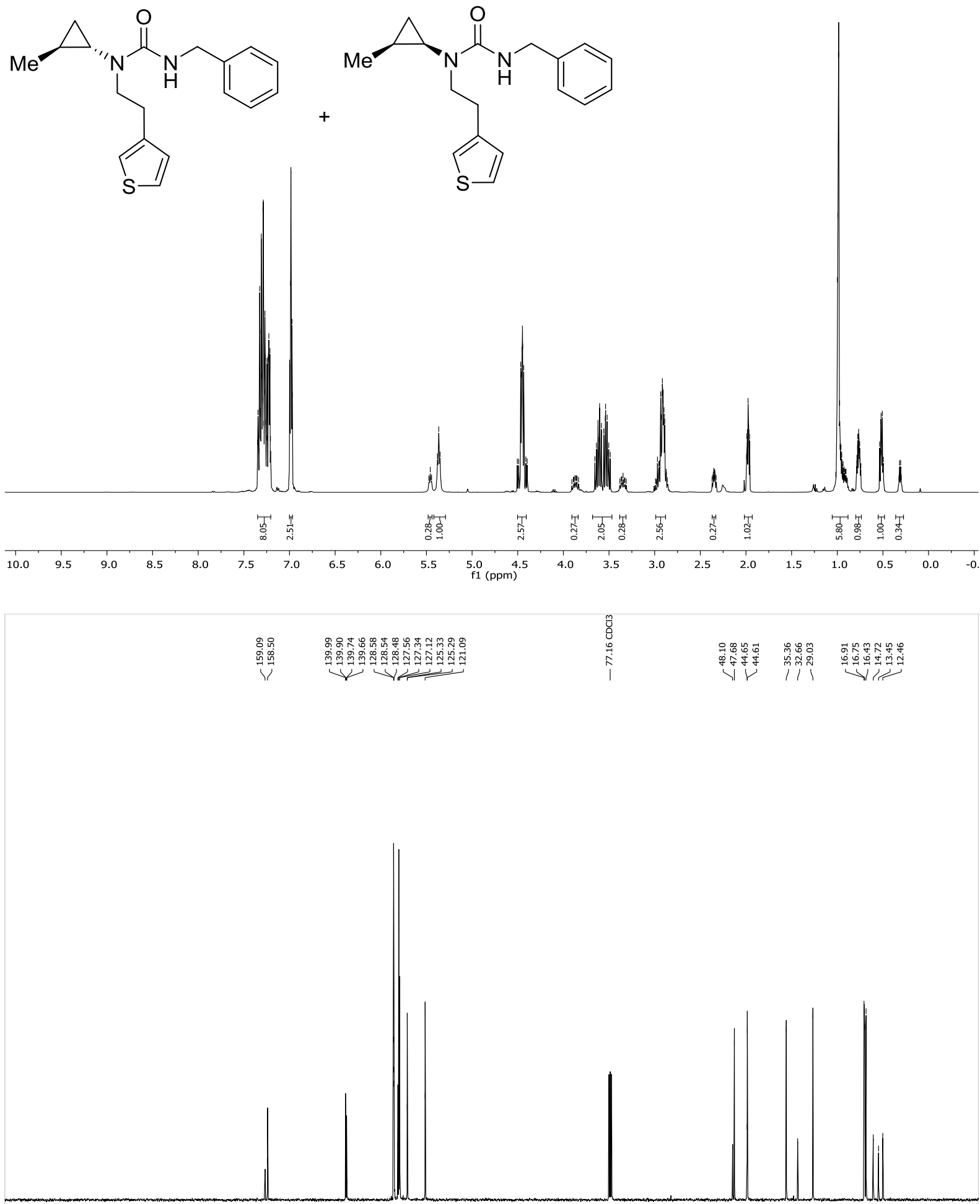

$\begin{array}{llllllllllllllllllllllll}120 & 210 & 200 & 190 & 180 & 170 & 160 & 150 & 140 & 130 & 120 & \underset{f}{110}(\mathrm{ppm}) & 100 & 90 & 70 & 60 & 50 & 40 & 30 & 20 & 10 & 0 & -1\end{array}$ 
(S)-1-Benzyl-6-methyl-3-(2-(thiophen-3-yl)ethyl)-3,6-dihydro-1H-1,3-diazepine-2,7-dione $2 \mathrm{~g}$ ${ }^{1} \mathrm{H} \mathrm{NMR}$ and ${ }^{13} \mathrm{C} \mathrm{NMR}$ in $\mathrm{CDCl}_{3}$

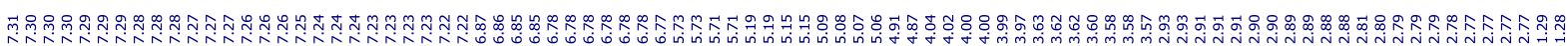<smiles>CC1C=CN(CCc2ccsc2)C(=O)N(Cc2ccccc2)C1=O</smiles>

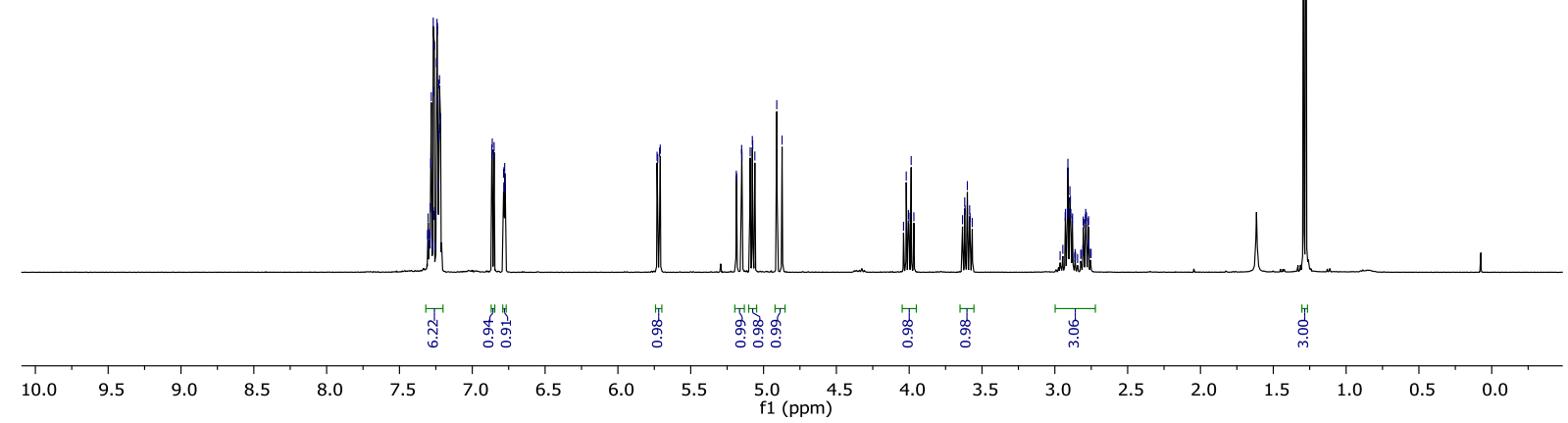

I

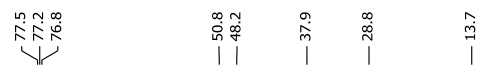

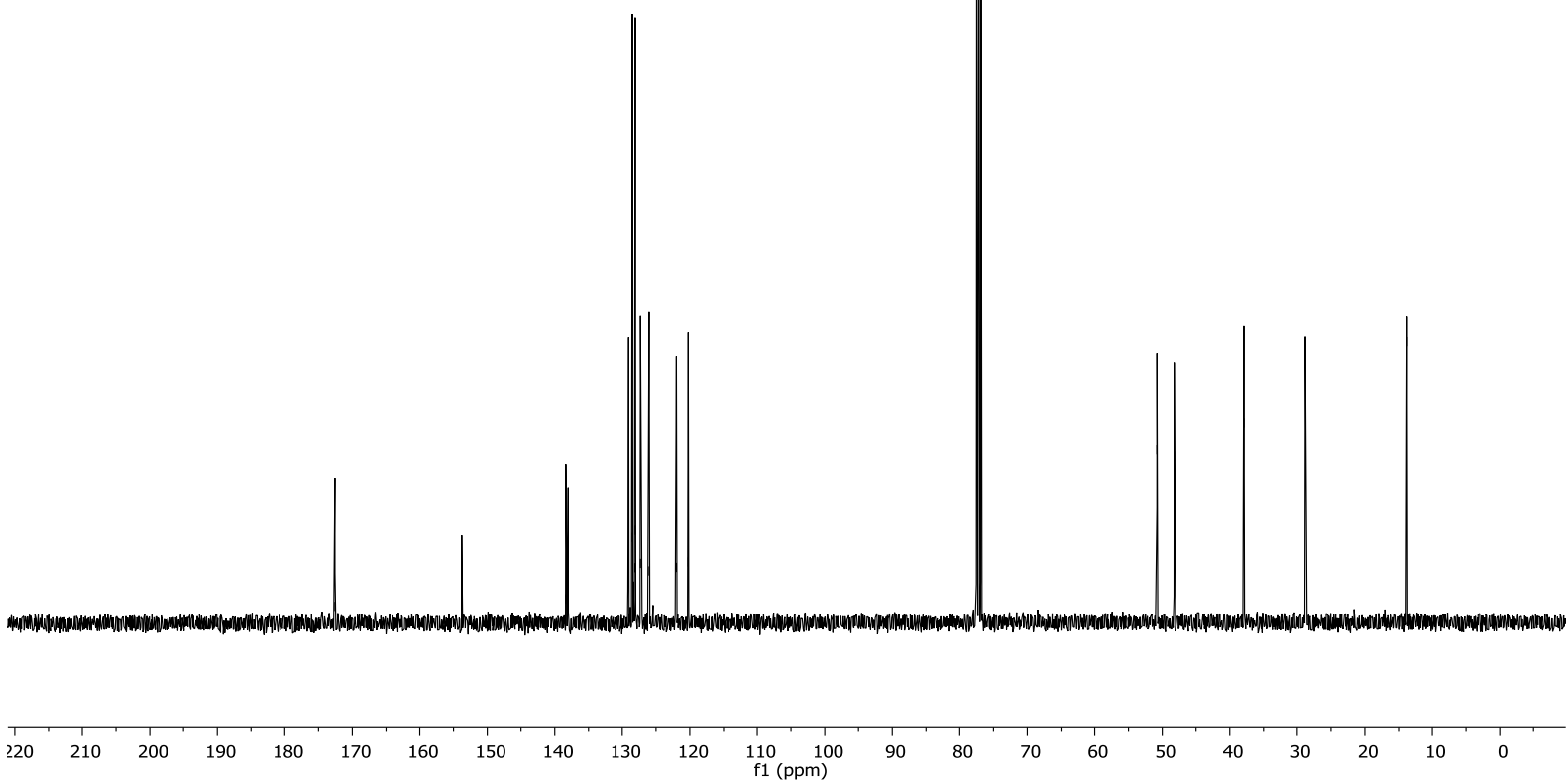


(8S,9aS)-8-Methyl-4,8,9,9a-tetrahydrothieno[3,2-g]indolizin-7(5H)-one and (8S,9aR)-8methyl-4,8,9,9a-tetrahydrothieno[3,2-g]indolizin-7(5H)-one $4 \mathrm{~g}{ }^{1} \mathrm{H}$ NMR and ${ }^{13} \mathrm{C}$ NMR in $\mathrm{CDCl}_{3}$

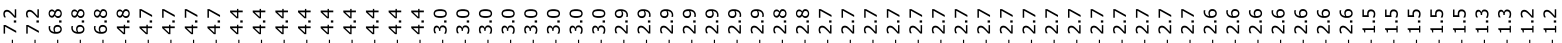<smiles>[H]/C=C\[C@H]1C[C@H]2c3sccc3CCN2C1=O</smiles>

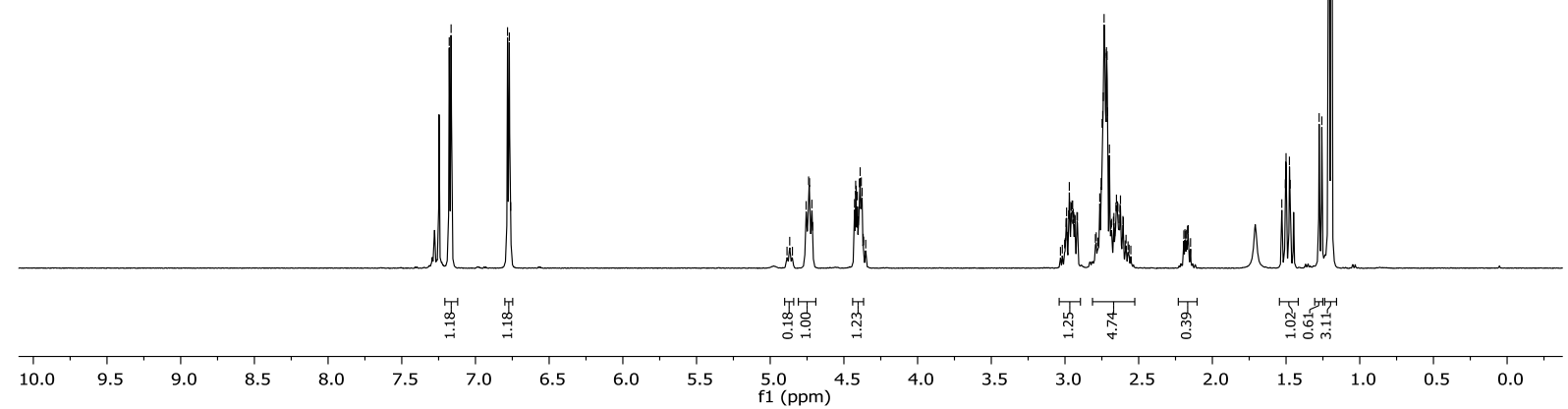

\begin{tabular}{|c|c|c|c|c|c|}
\hline $\begin{array}{c}\stackrel{2}{\sim} \\
\stackrel{N}{N} \\
1\end{array}$ & 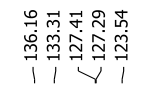 & 喬. & مْ & 商怘 & 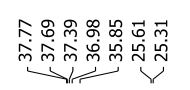 \\
\hline
\end{tabular}

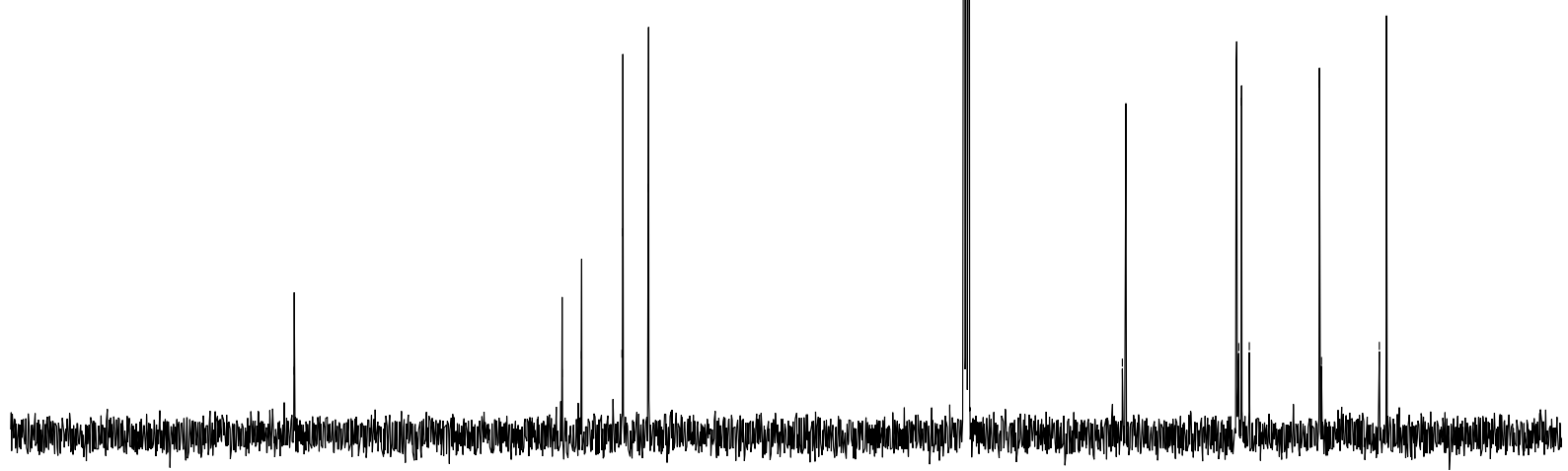

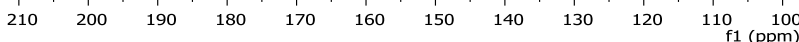


3-Benzyl-1-((1S*,2S*)-2-benzylcyclopropyl)-1-(3,4-dimethoxyphenethyl)urea $1 \mathrm{~h} \quad{ }^{1} \mathrm{H}$ NMR and ${ }^{13} \mathrm{C} \mathrm{NMR}$ in $\mathrm{CDCl}_{3}$

\%ั0

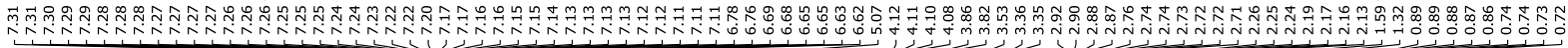<smiles>COc1ccc(CCN(C(=O)NCc2ccccc2)[C@@H]2C[C@H]2Cc2ccccc2)cc1OC</smiles>
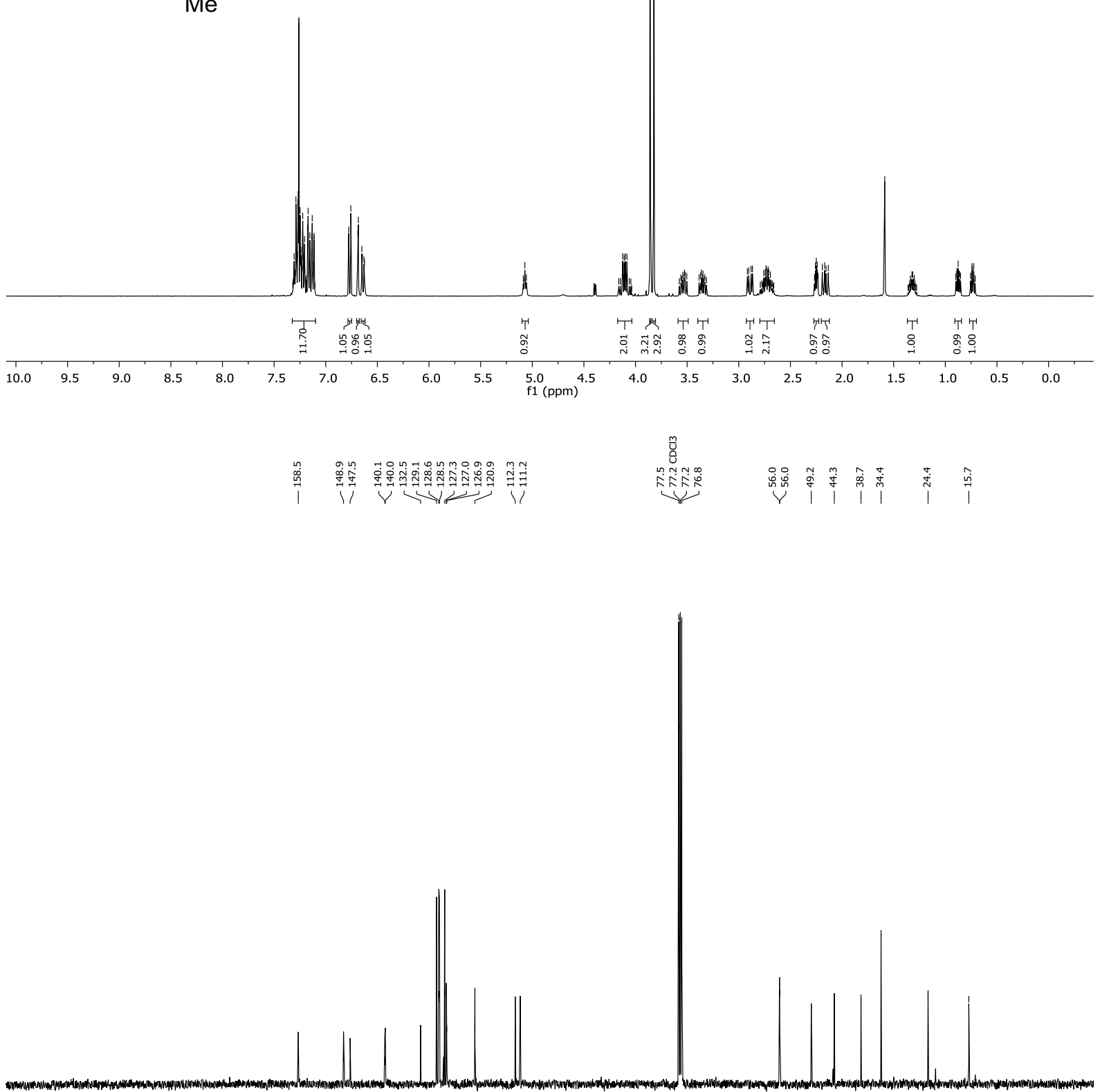

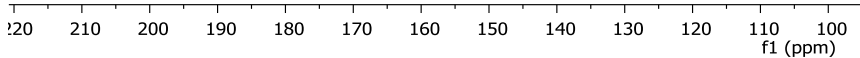



$\mathrm{NMR}$ and ${ }^{13} \mathrm{C} \mathrm{NMR}$ in $\mathrm{CDCl}_{3}$

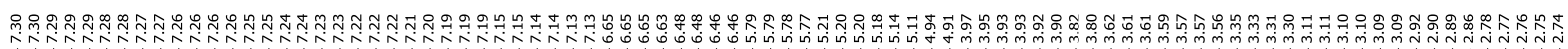<smiles>COc1ccc(CCN2C=CC(Cc3ccccc3)C(=O)N(Cc3ccccc3)C2=O)cc1OC</smiles>
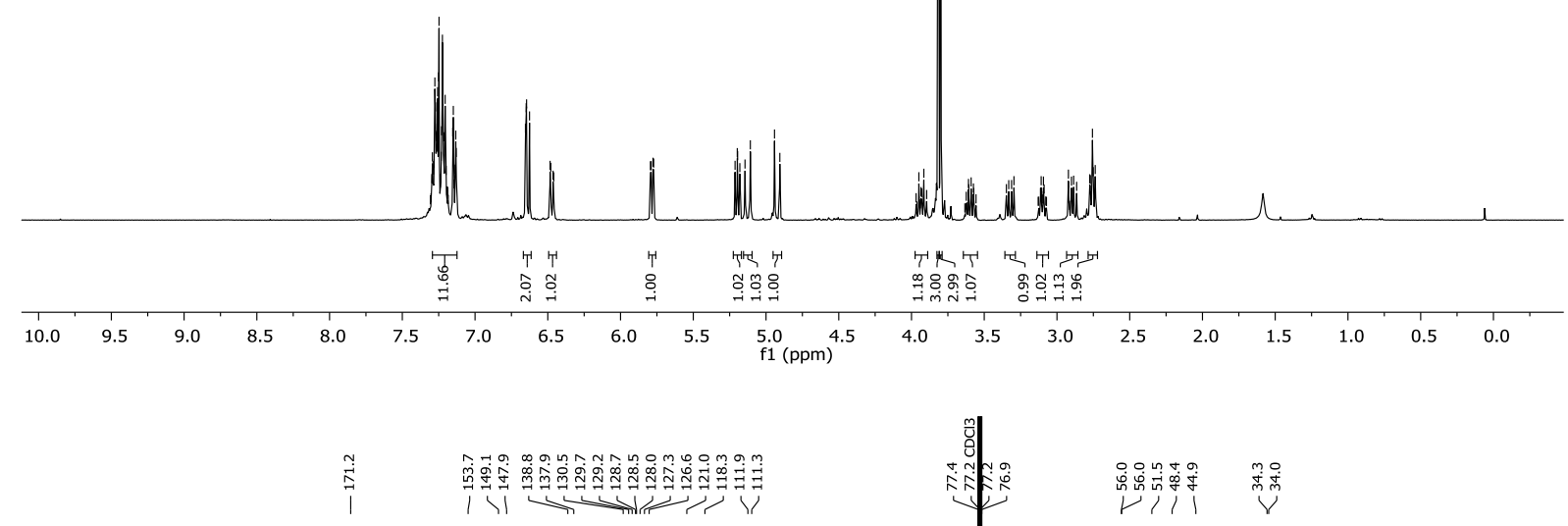

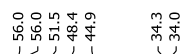

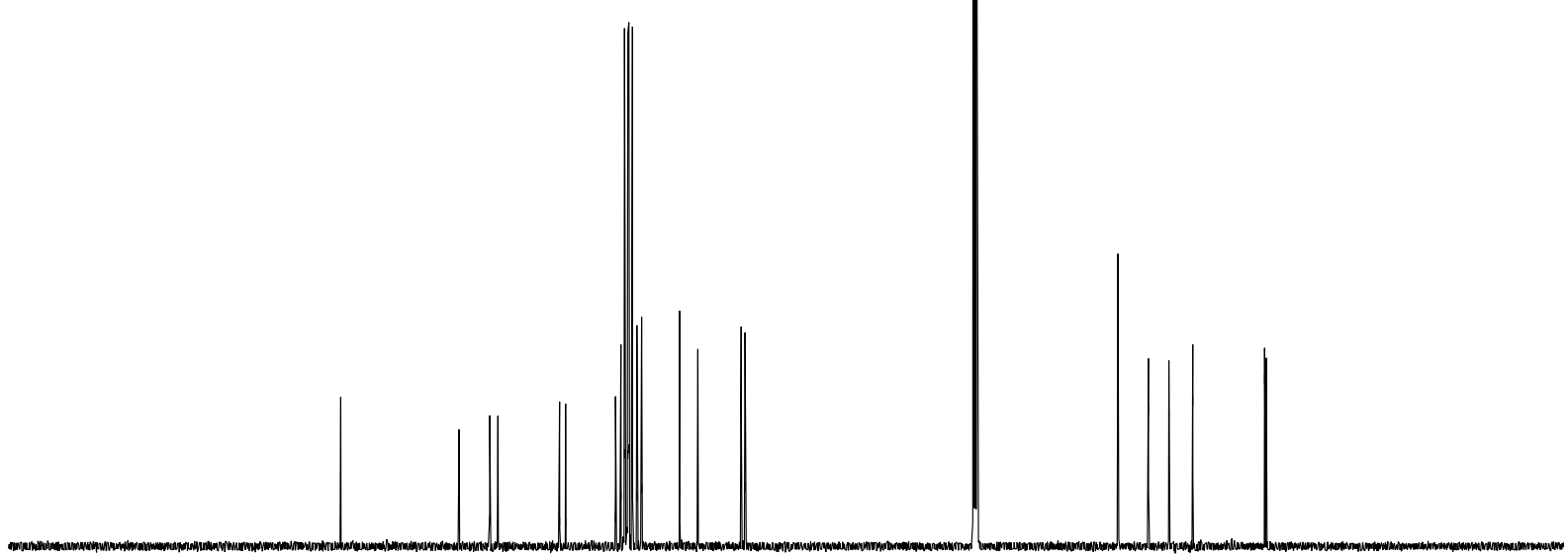

$\begin{array}{llllllllllll}20 & 210 & 200 & 190 & 180 & 170 & 160 & 150 & 140 & 130 & 120 & \begin{array}{c}110 \\ \mathrm{f} 1(\mathrm{ppm})\end{array} \\ & & & & \end{array}$ 
$\left(2 S^{*}, 10 \mathrm{~b} S^{*}\right)$-2-Benzyl-8,9-dimethoxy-1,5,6,10b-tetrahydropyrrolo[2,1-a]isoquinolin-3(2H)one and $\left(2 S^{*}, 10 \mathrm{~b} R^{*}\right)-2-B e n z y l-8,9-d i m e t h o x y-1,5,6,10 \mathrm{~b}-$-tetrahydropyrrolo[2,1a]isoquinolin-3(2H)-one $4 \mathbf{h}{ }^{1} \mathrm{H} \mathrm{NMR}$ and ${ }^{13} \mathrm{C} \mathrm{NMR}$ in $\mathrm{CDCl}_{3}$

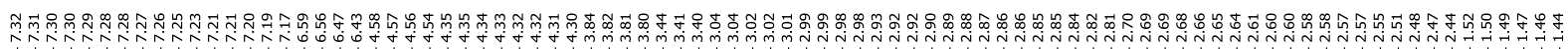<smiles>COc1cc2c(cc1OC)[C@H]1CC(Cc3ccccc3)C(=O)N1CC2</smiles><smiles>COc1cc2c(cc1OC)[C@H]1CC(Cc3ccccc3)C(=O)N1CC2</smiles>

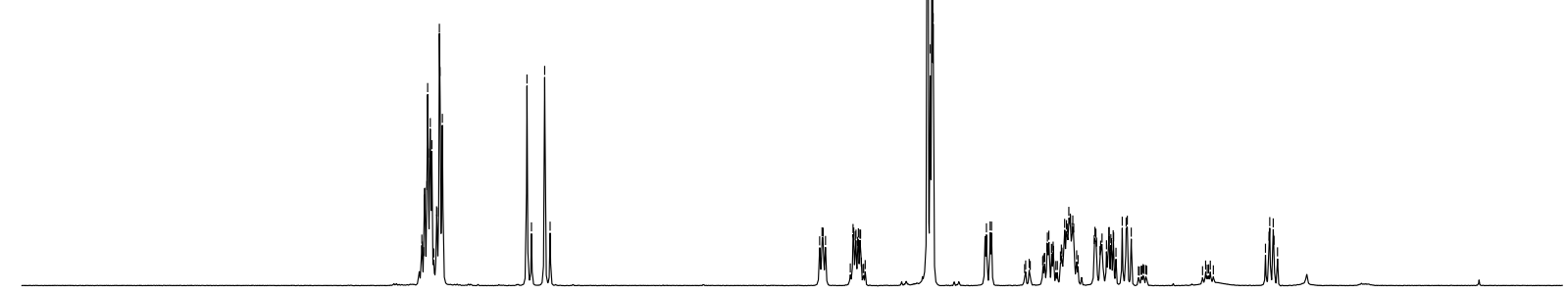

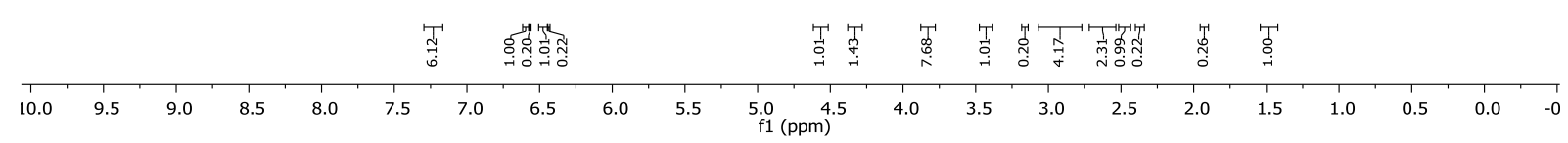

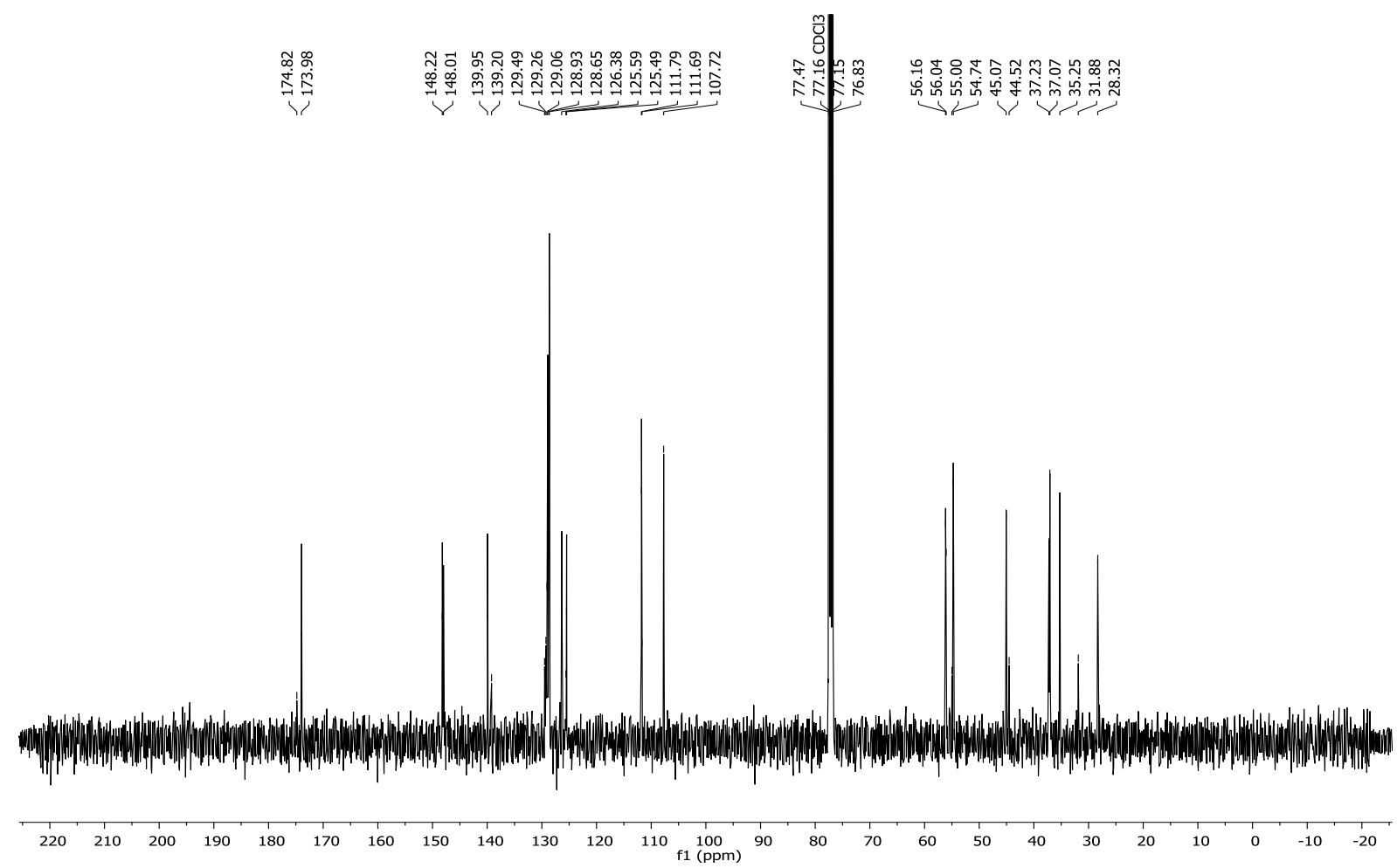


3-Cyclohexyl-1-cyclopropyl-1-((3E,5E and 3Z,5E)-hepta-3,5-dien-1-yl)urea $1 \mathrm{i}{ }^{1} \mathrm{H}$ NMR and ${ }^{13} \mathrm{C} \mathrm{NMR}$ in $\mathrm{CDCl}_{3}$

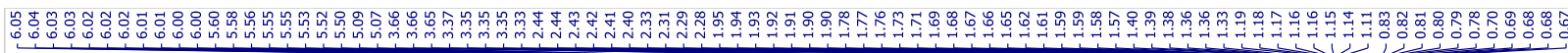
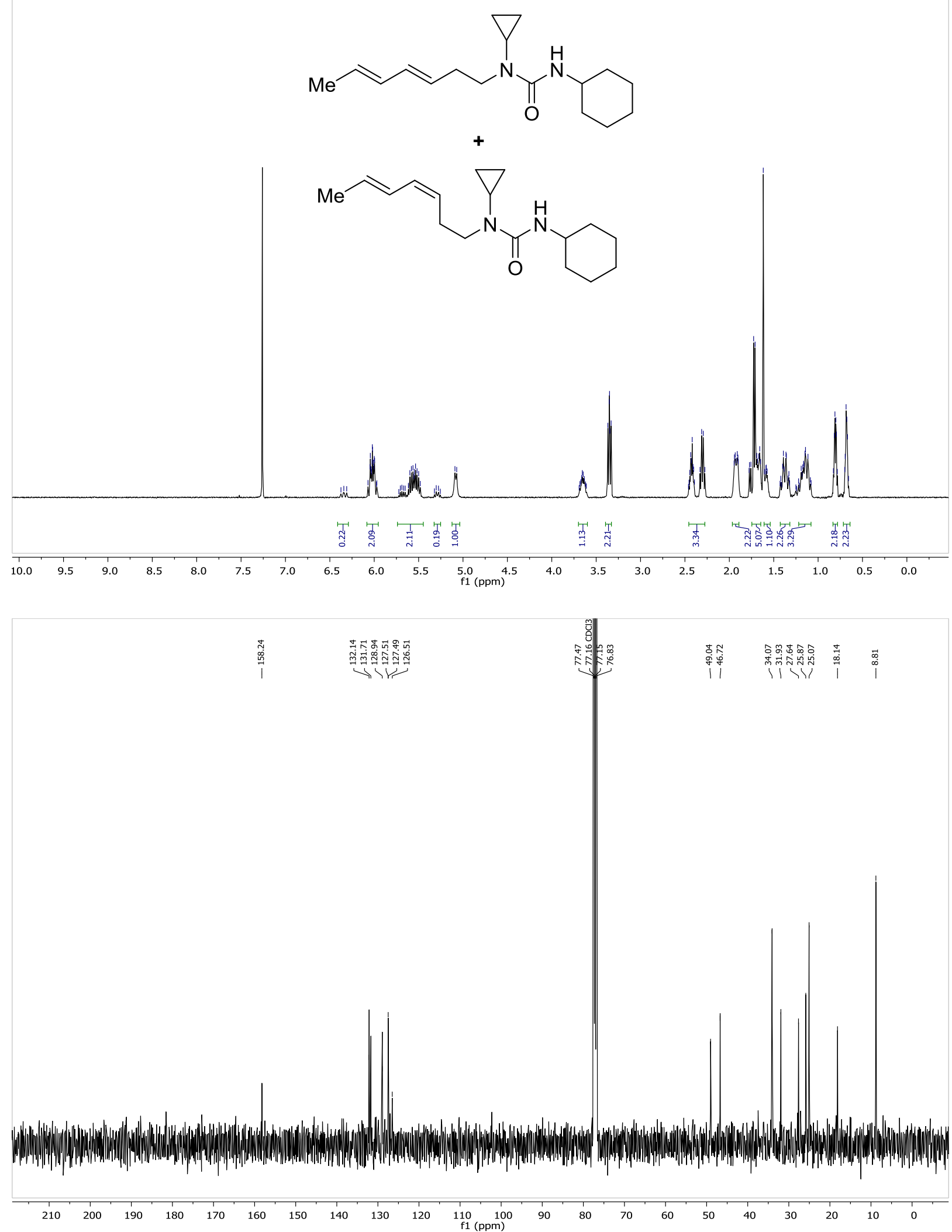
$\left(3^{1} R^{*}, 5 \mathrm{a} R^{*}, 8 S^{*}, 8 \mathrm{a} S^{*}\right)-8-M e t h y l-3{ }^{1}, 4,5,5 \mathrm{a}, 8,8 \mathrm{a}-h$ exahydropyrrolo[3,2,1-hi]indol-2(1H)-one $4 \mathbf{i}^{1} \mathrm{H}$ NMR and ${ }^{13} \mathrm{C}$ NMR in $\mathrm{CDCl}_{3}$

鱼

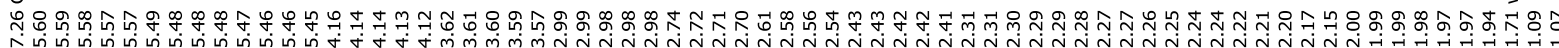<smiles>O=C1C[C@@H]2CC=C[C@H]3CCN1[C@H]23</smiles>
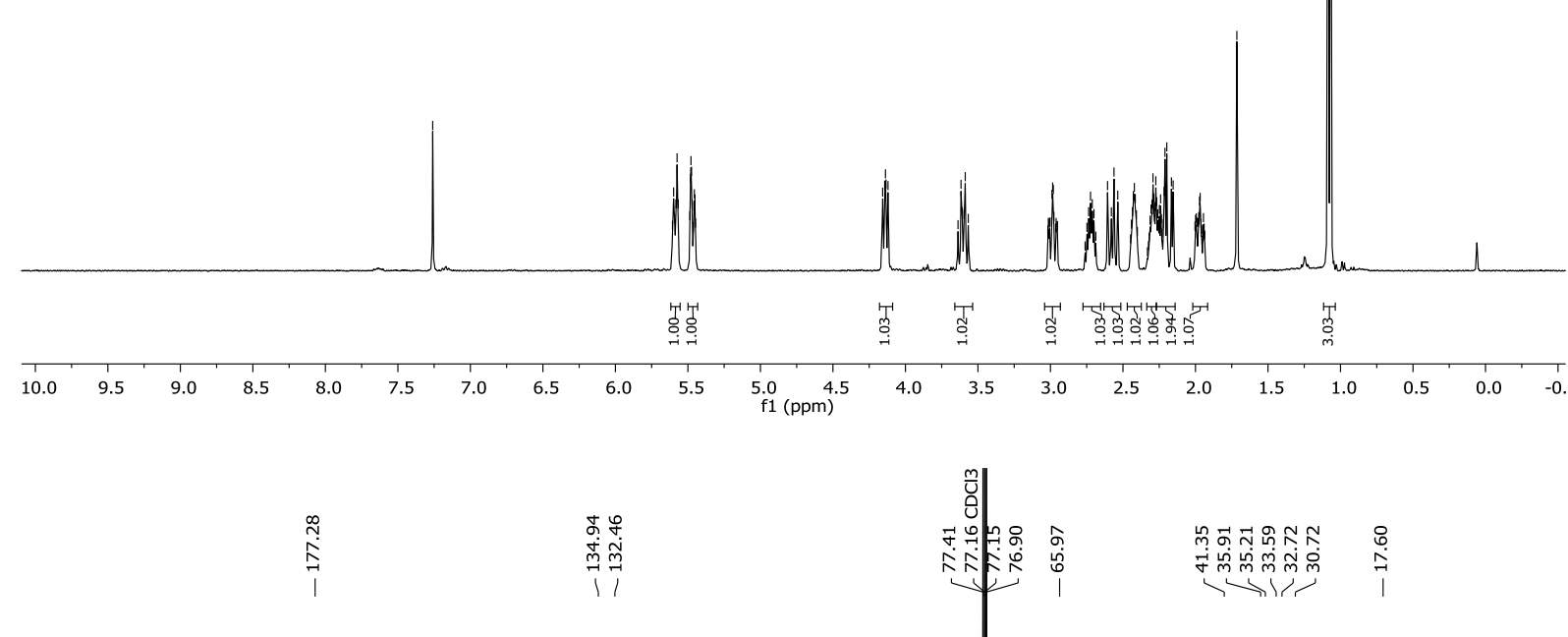

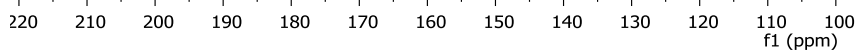


(3E,5E and 3Z,5E)-6-(4-Fluorophenyl)hexa-3,5-dien-1-ol ${ }^{1} \mathrm{H}$ NMR, ${ }^{13} \mathrm{C}$ NMR and ${ }^{19} \mathrm{~F}$ NMR in $\mathrm{CDCl}_{3}$

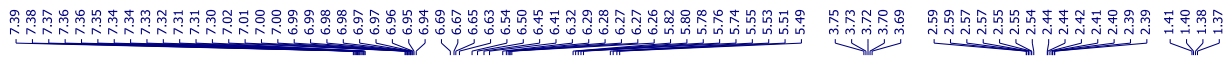
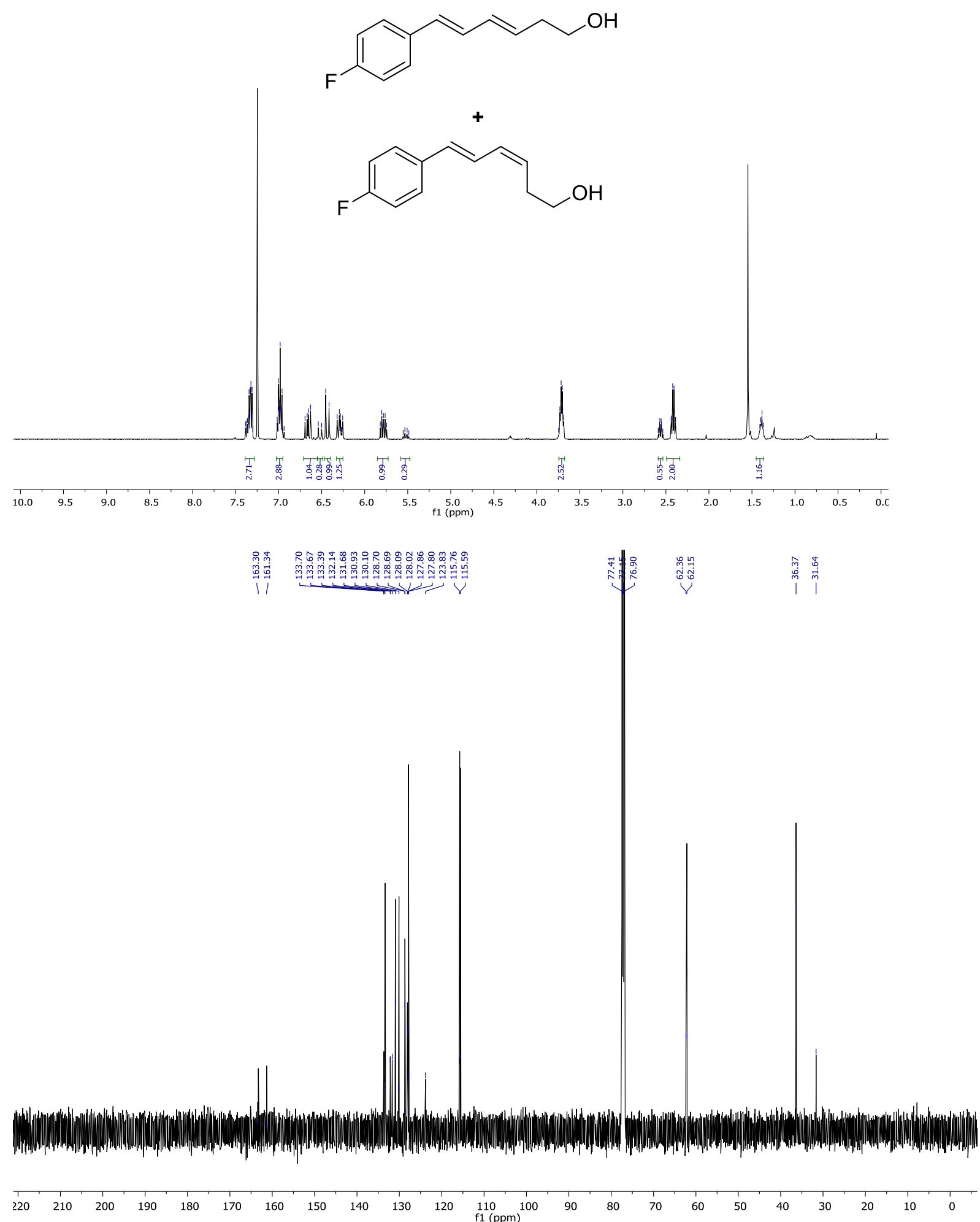


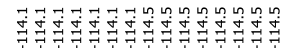

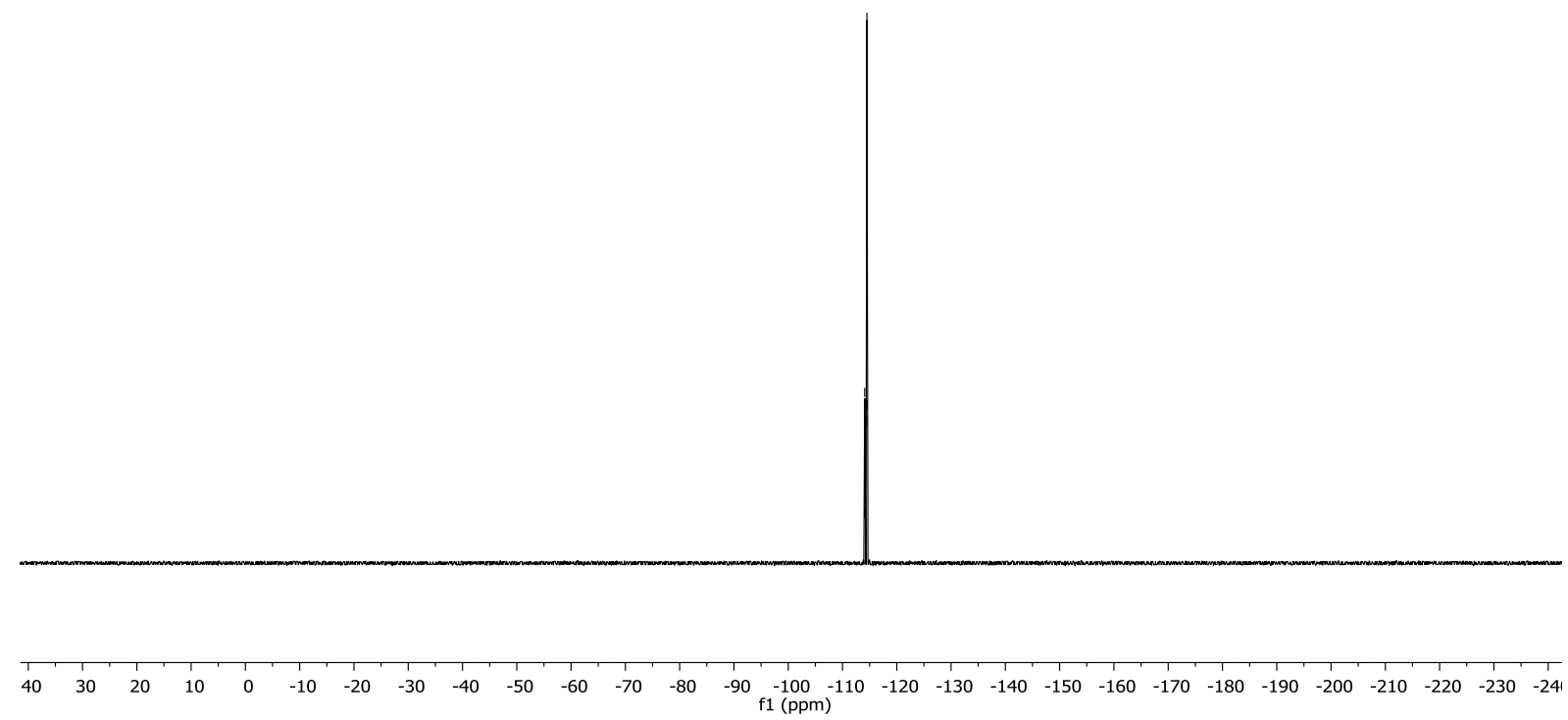


3-Cyclohexyl-1-cyclopropyl-1-((3E,5E)-6-(4-fluorophenyl)hexa-3,5-dien-1-yl)urea $1 \mathbf{j}{ }^{1} \mathrm{H}$ $\mathrm{NMR},{ }^{13} \mathrm{C} \mathrm{NMR}$ and ${ }^{19} \mathrm{~F}$ NMR in $\mathrm{CDCl}_{3}$

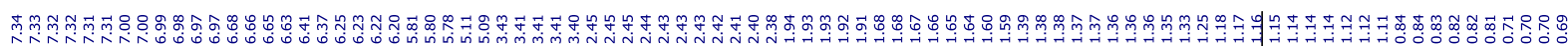

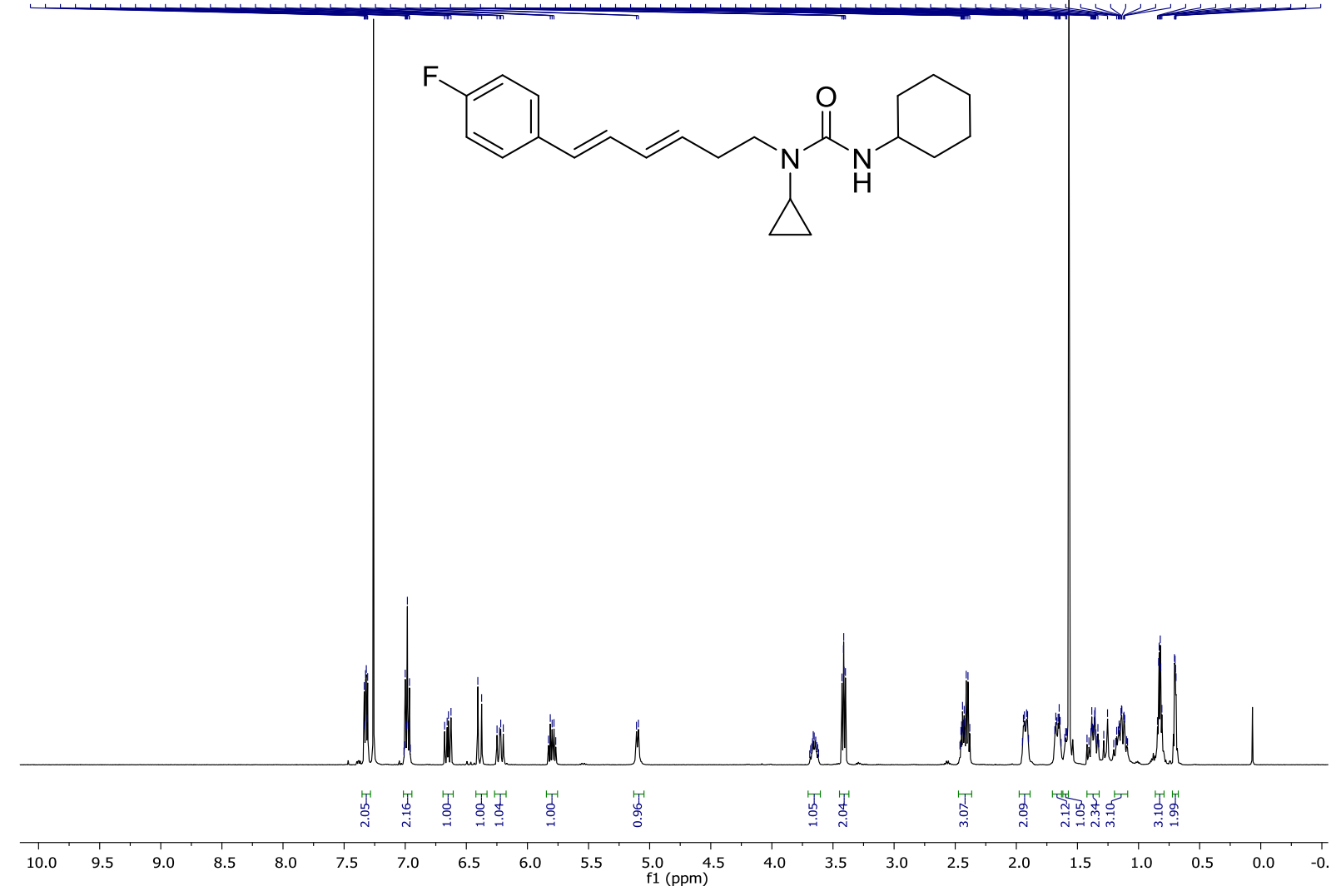

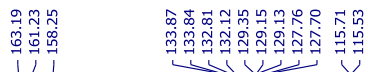

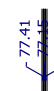

|

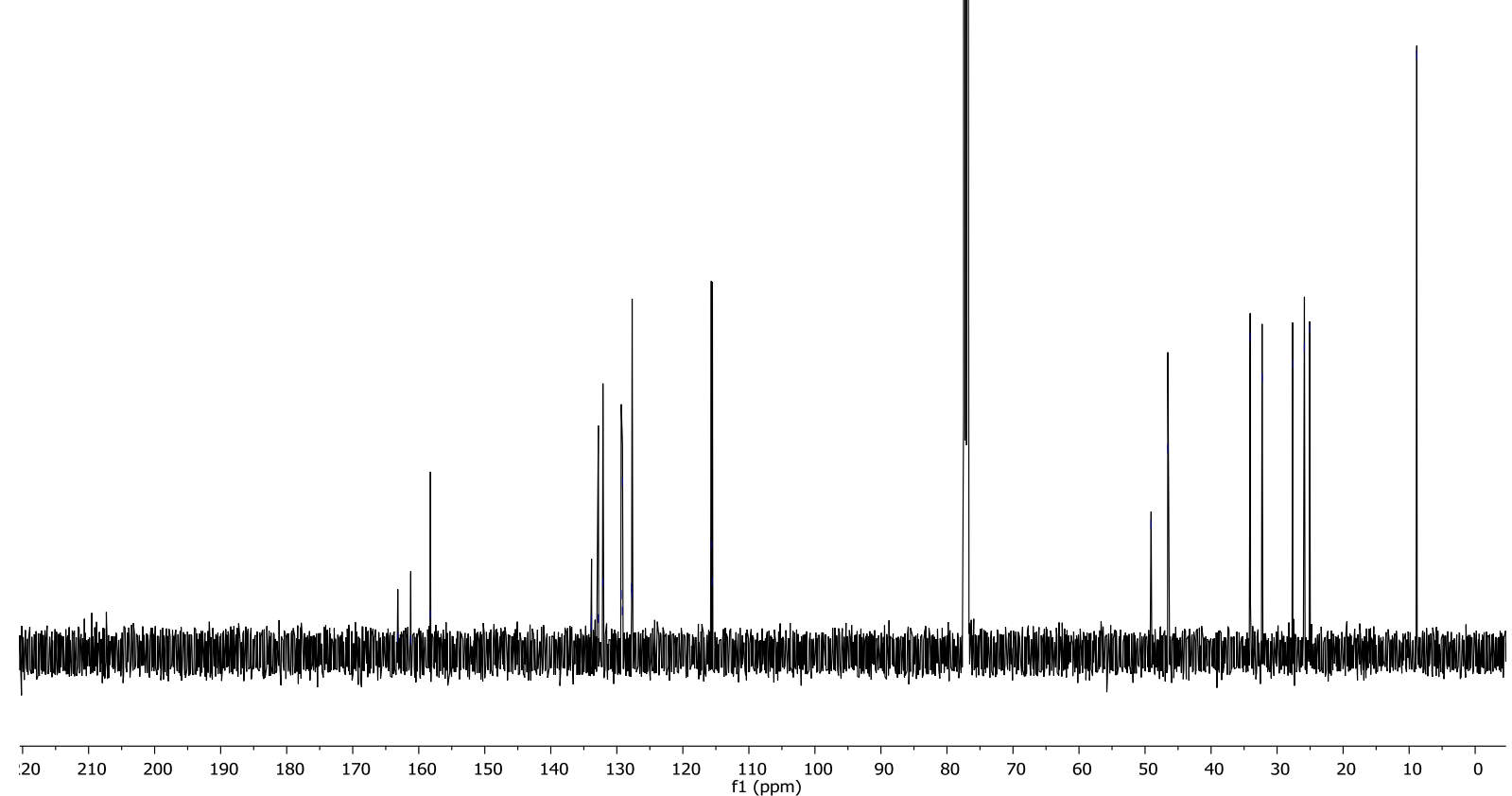




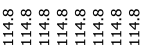

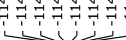

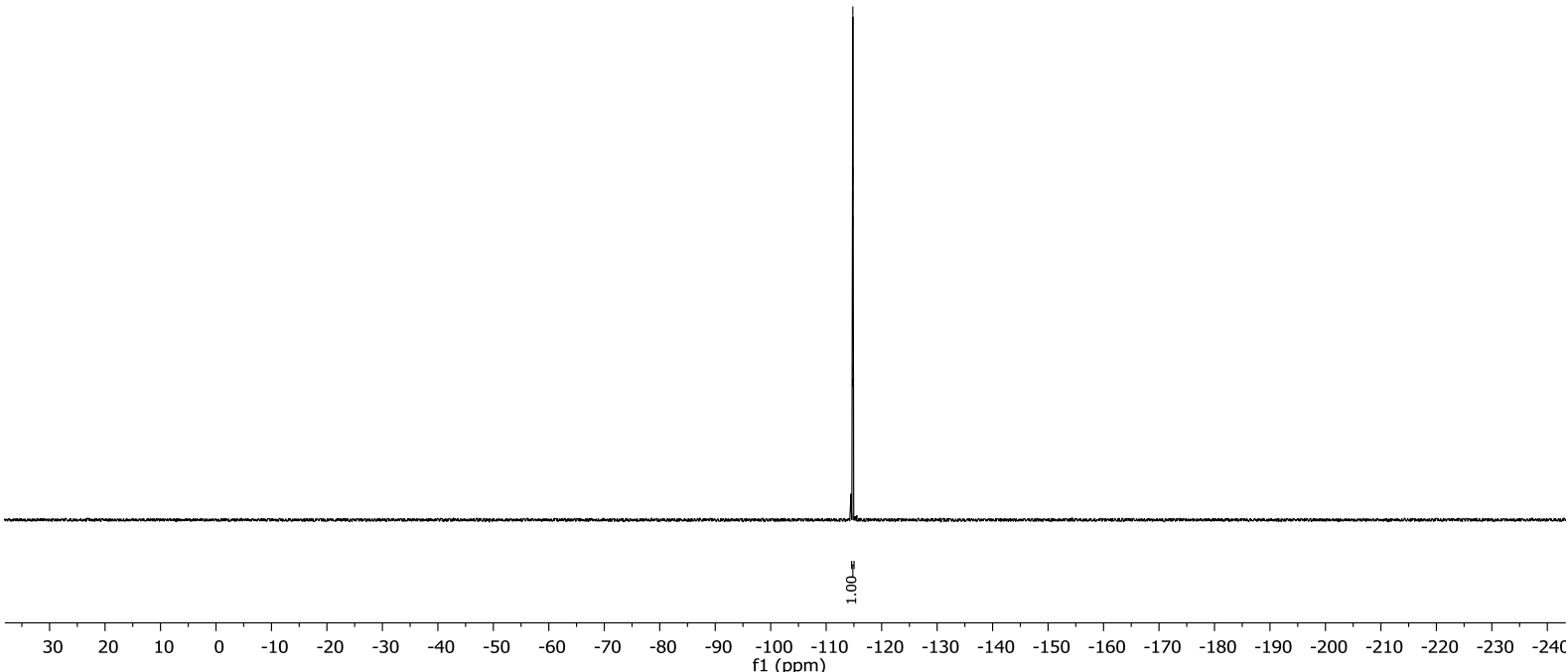




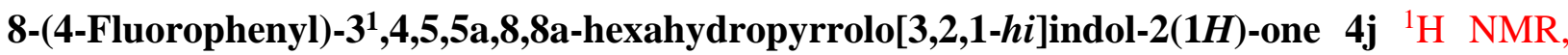
${ }^{13} \mathrm{C} \mathrm{NMR}$ and ${ }^{19} \mathrm{~F} \mathrm{NMR}$ in $\mathrm{CDCl}_{3}$

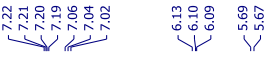

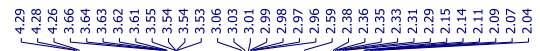<smiles>O=C1C[C@@H]2C3[C@@H](C=C[C@H]2c2ccc(F)cc2)CCN13</smiles>

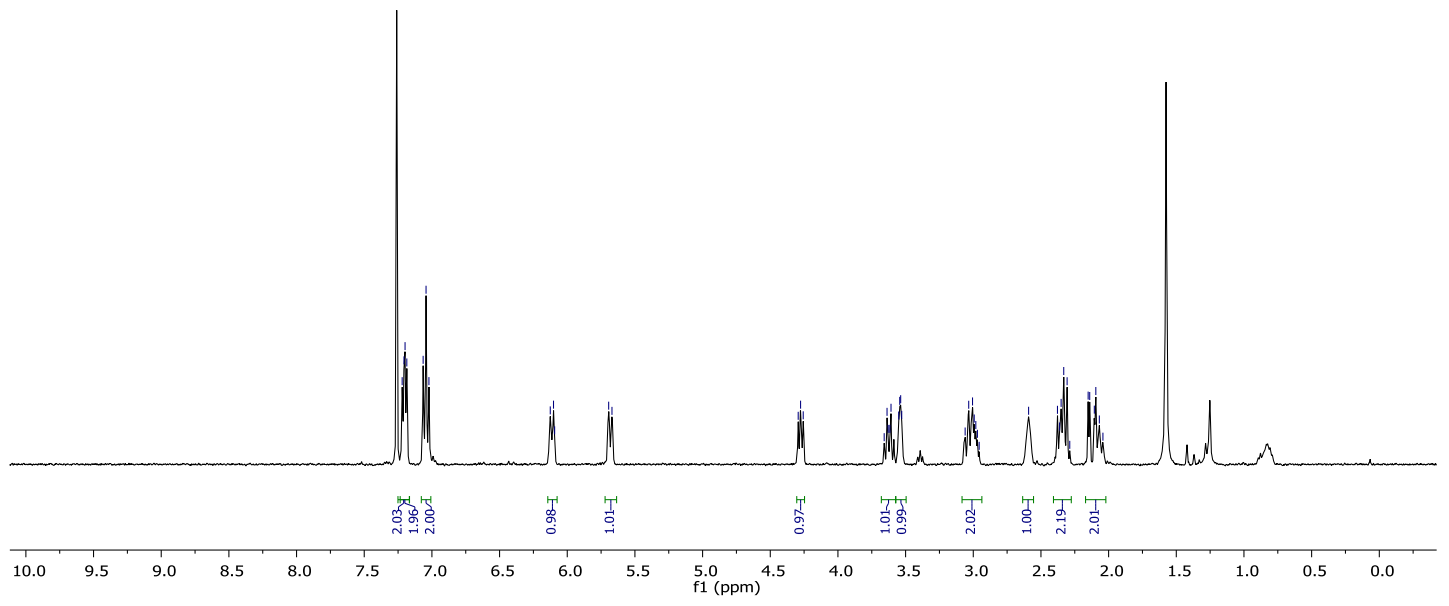

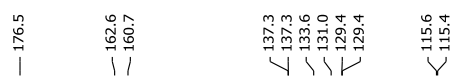

$\overbrace{\substack{\infty \\ \infty}}^{2}$

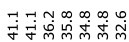

$\checkmark$ प1

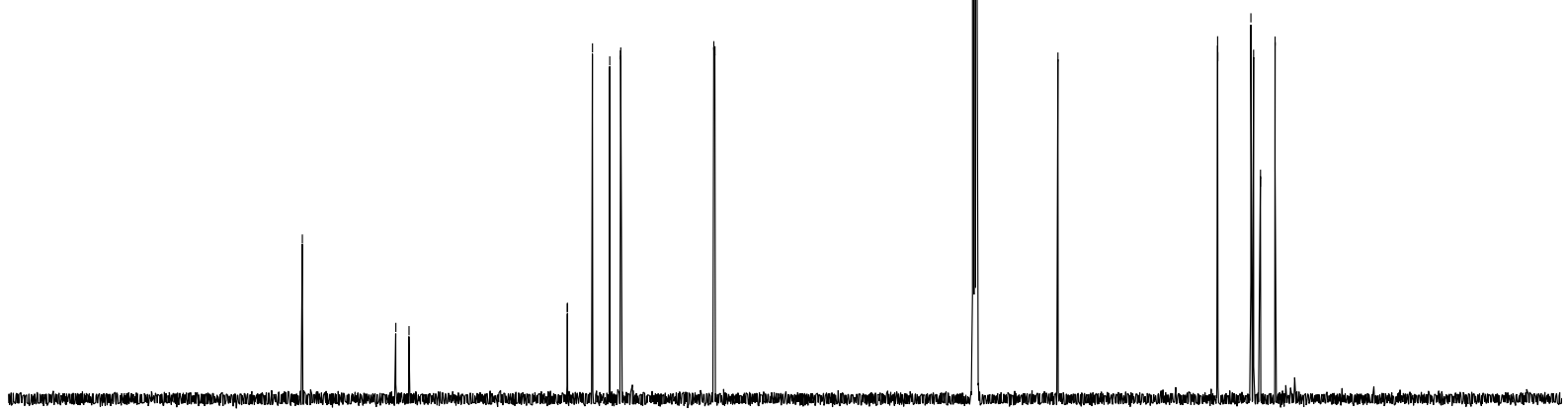

$\begin{array}{llllllllllll}210 & 200 & 190 & 180 & 170 & 160 & 150 & 140 & 130 & 120 & 110 & 1 \\ \text { f } 1(\mathrm{ppm})\end{array}$ 


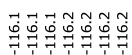

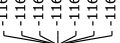

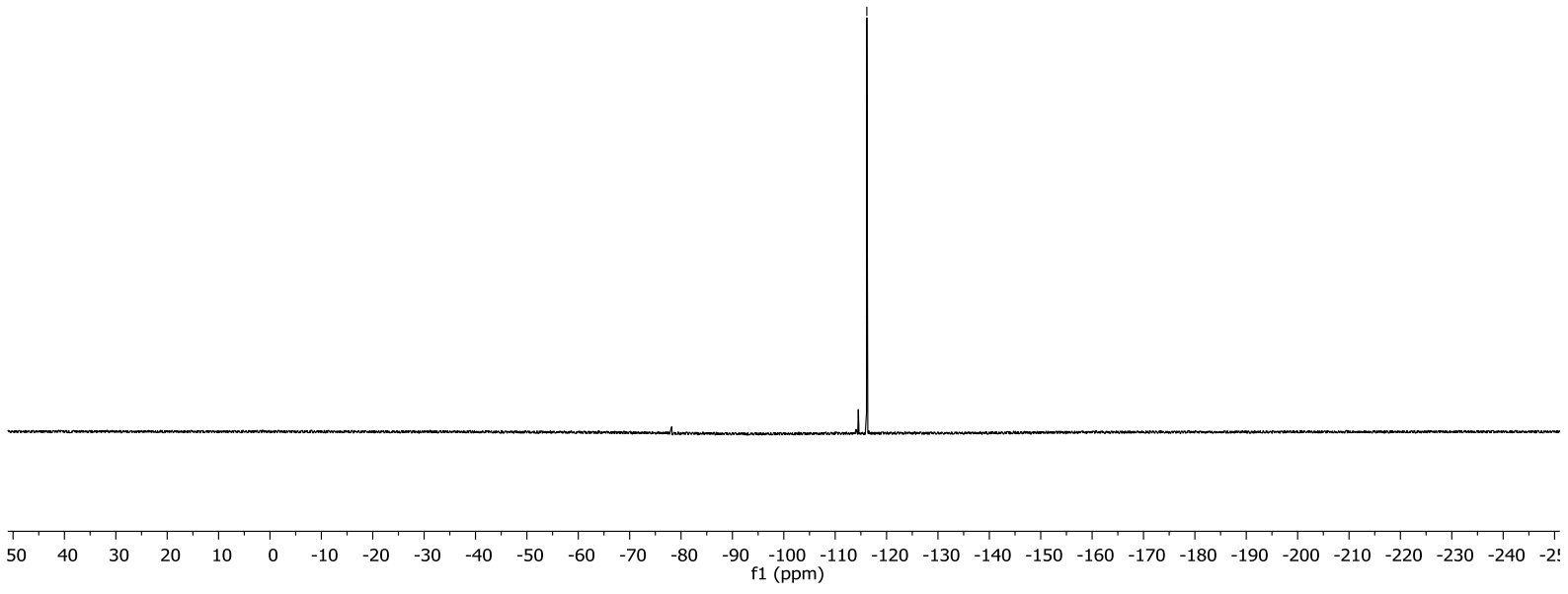


$\boldsymbol{N}$-(4-Phenylbut-3-yn-1-yl)cyclopropanamine 5k ${ }^{1} \mathrm{H}$ NMR and ${ }^{13} \mathrm{C} \mathrm{NMR} \mathrm{in} \mathrm{CDCl}_{3}$

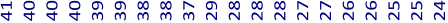

rivisisivis

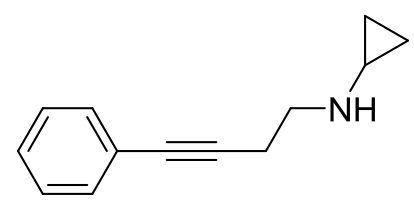

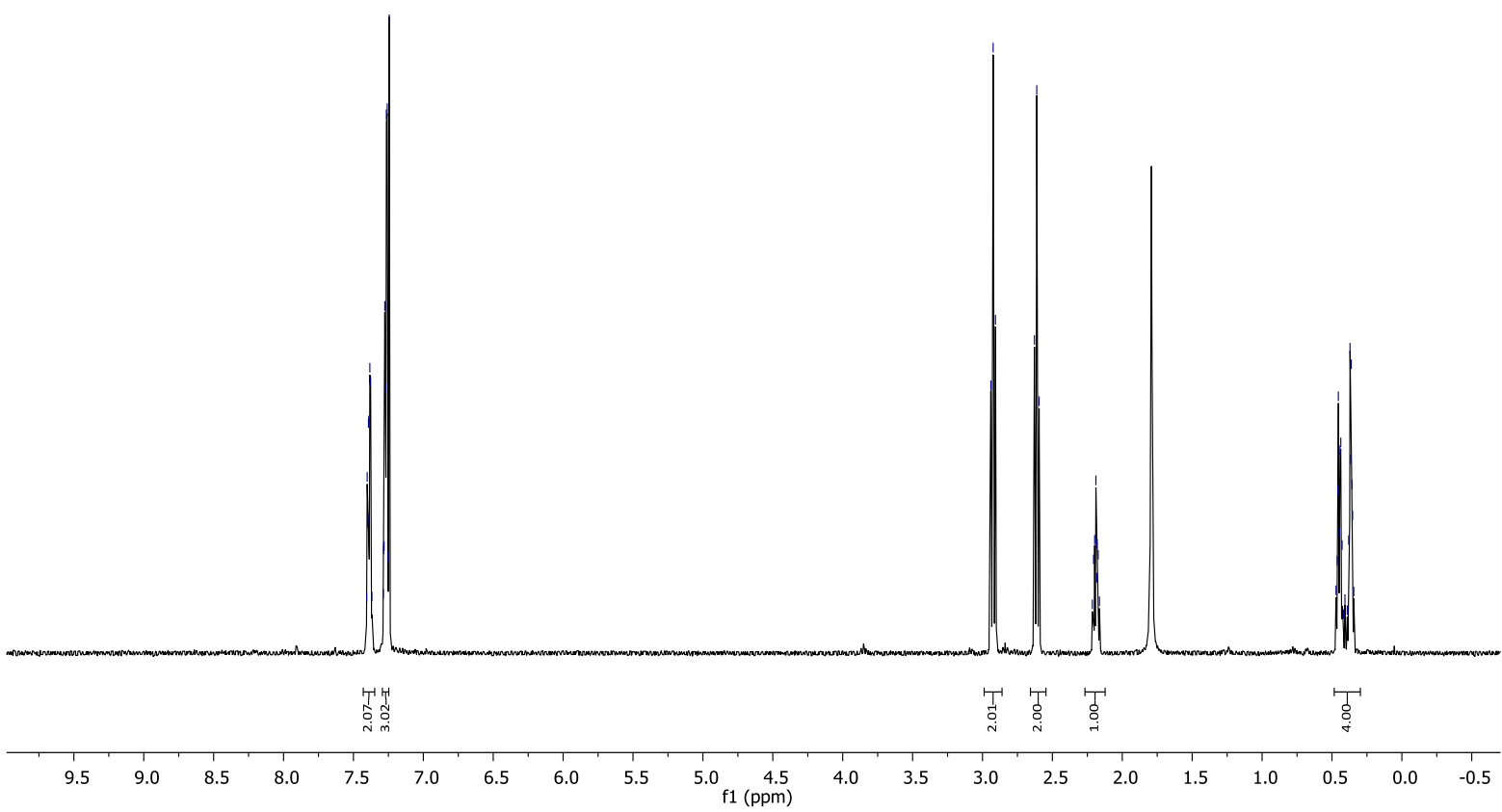

\section{min}

i 
3-Cyclohexyl-1-cyclopropyl-1-(4-phenylbut-3-yn-1-yl)urea $1 \mathbf{k}{ }^{1} \mathrm{H}$ NMR and ${ }^{13} \mathrm{C} N \mathrm{NM}$ in $\mathrm{CDCl}_{3}$

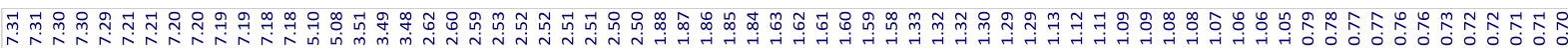
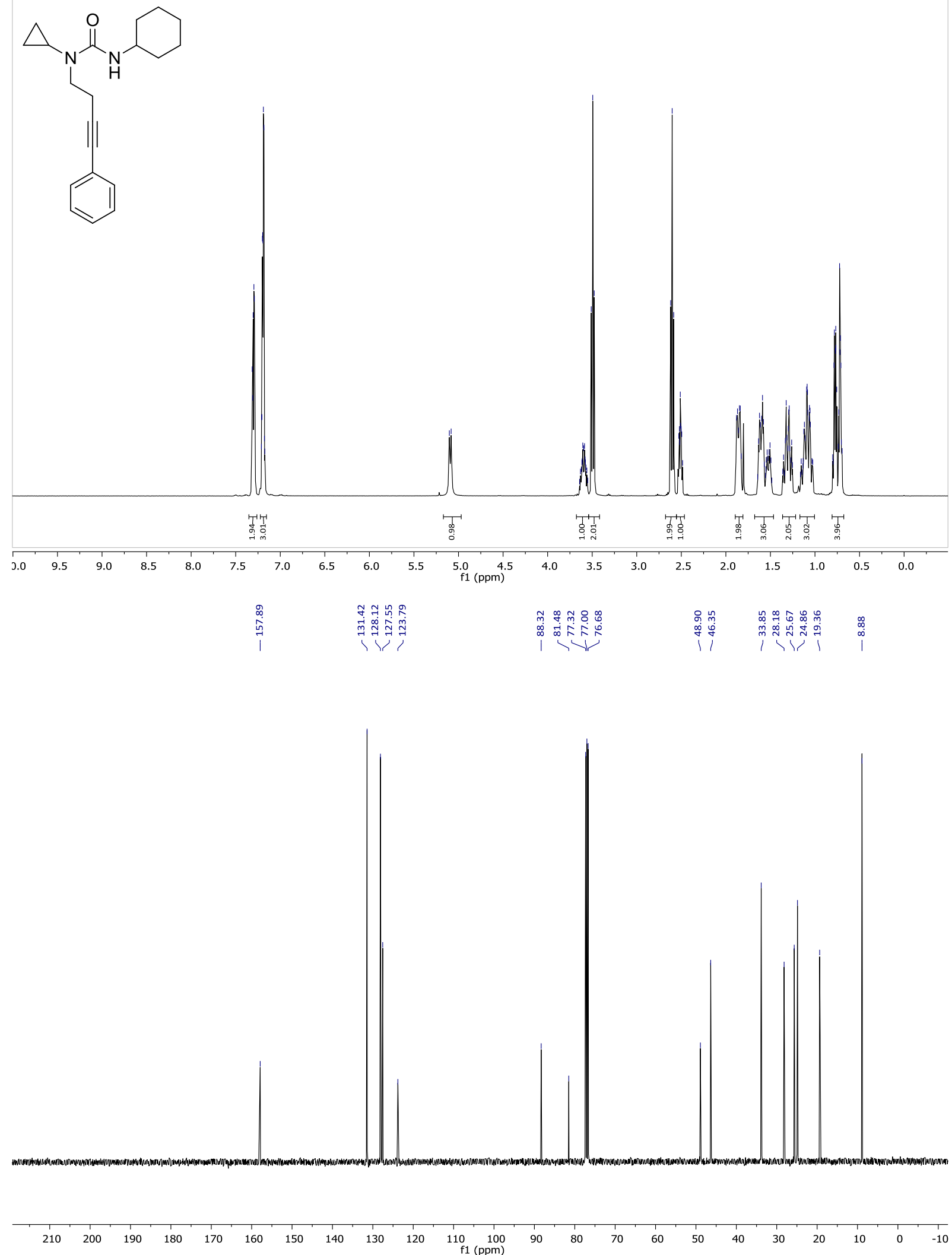
(E)-6-benzylidene-2-cyclohexylhexahydro-1H-pyrrolo[1,2-c][1,3]diazepine-1,3(2H)-dione 3k ${ }^{1} \mathrm{H}$ NMR and ${ }^{13} \mathrm{C} \mathrm{NMR}$ in $\mathrm{CDCl}_{3}$

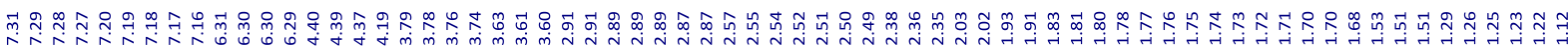
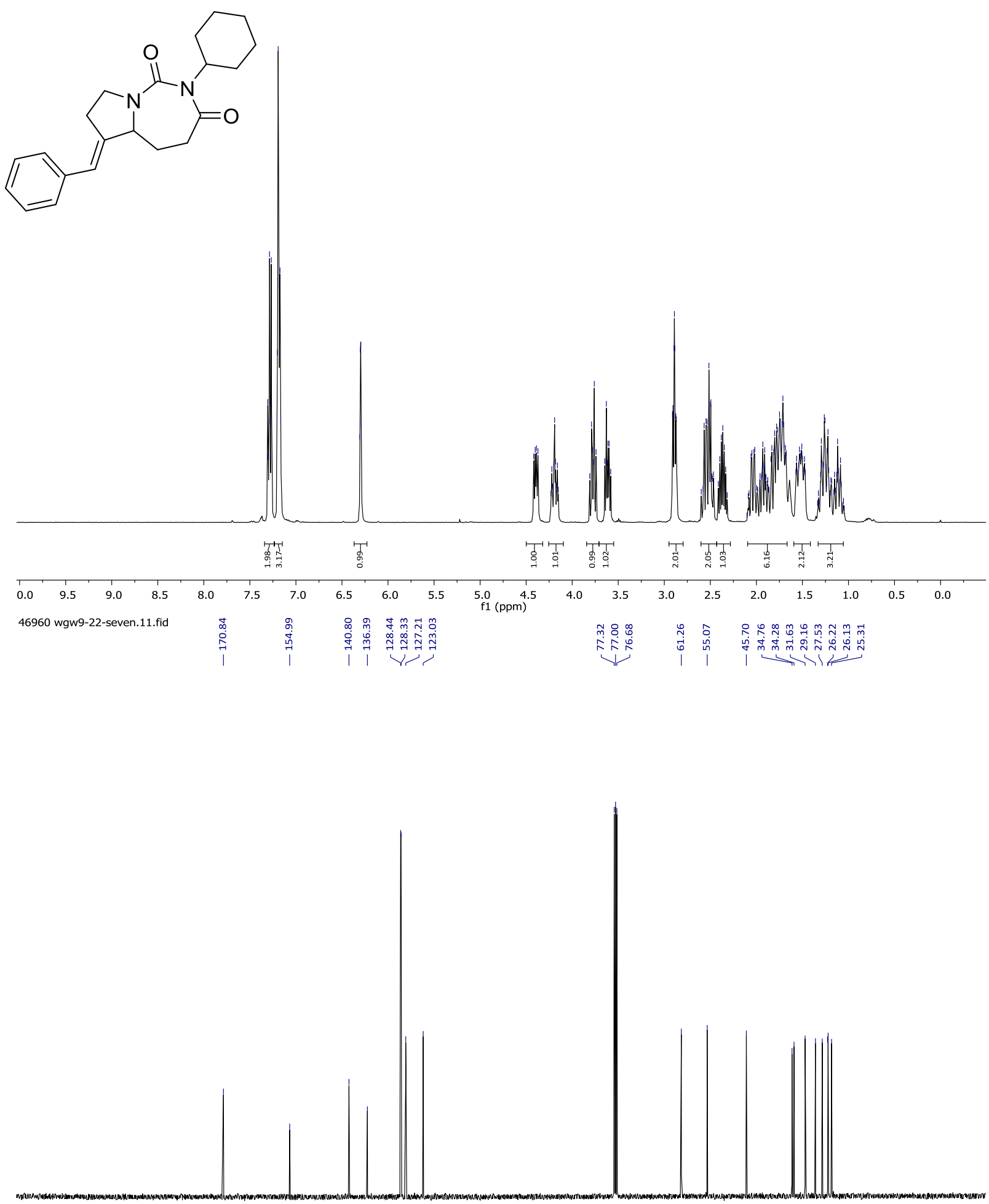

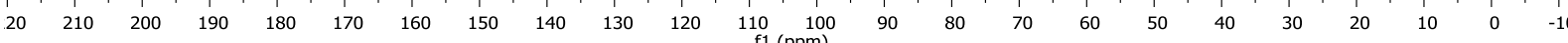


$\boldsymbol{N}$-(4-(4-Methoxyphenyl)but-3-yn-1-yl)cyclopropanamine $5 \mathbf{l}^{1} \mathrm{H}$ NMR and ${ }^{13} \mathrm{C} \mathrm{NMR}$ in $\mathrm{CDCl}_{3}$
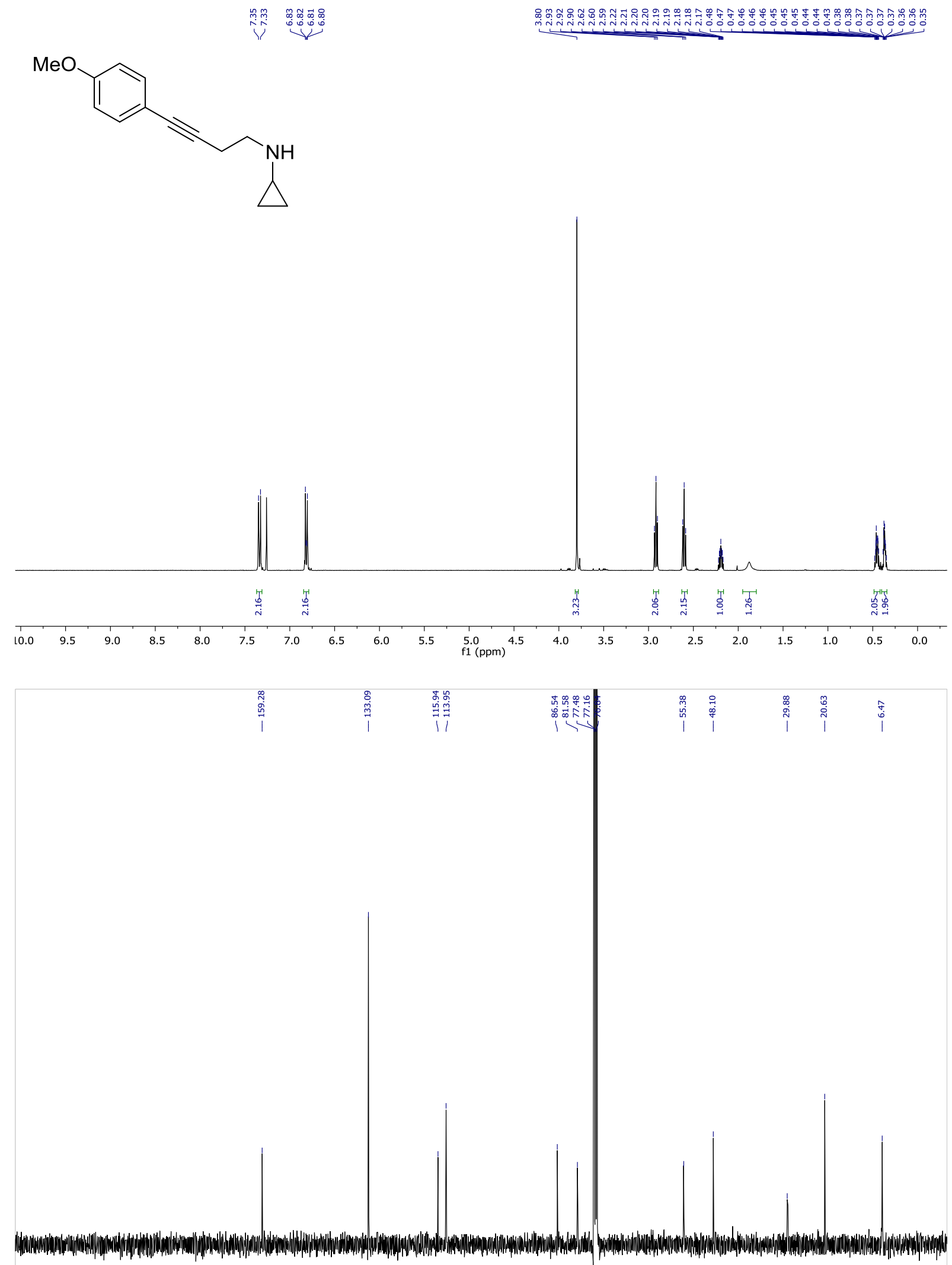

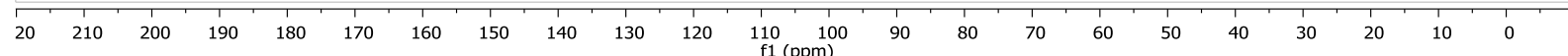


(E)-7-(4-Methoxybenzylidene)hexahydro-3H-pyrrolizin-3-one $4 \mathrm{l}{ }^{1} \mathrm{H}$ NMR and ${ }^{13} \mathrm{C}$ NMR in $\mathrm{CDCl}_{3}$

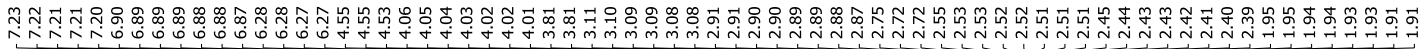<smiles>COc1ccc(/C=C2\CCN3C(=O)CCC23)cc1</smiles>

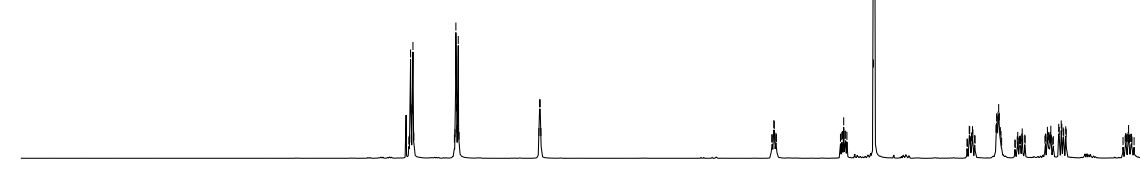

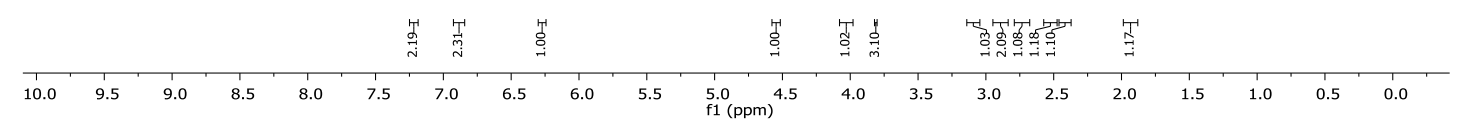

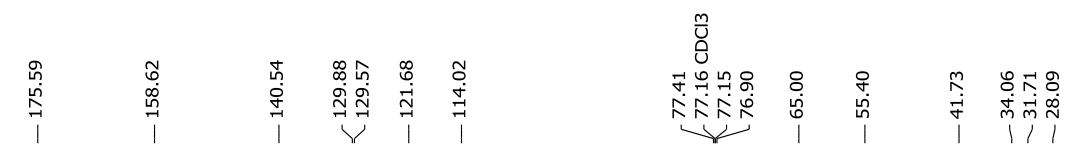

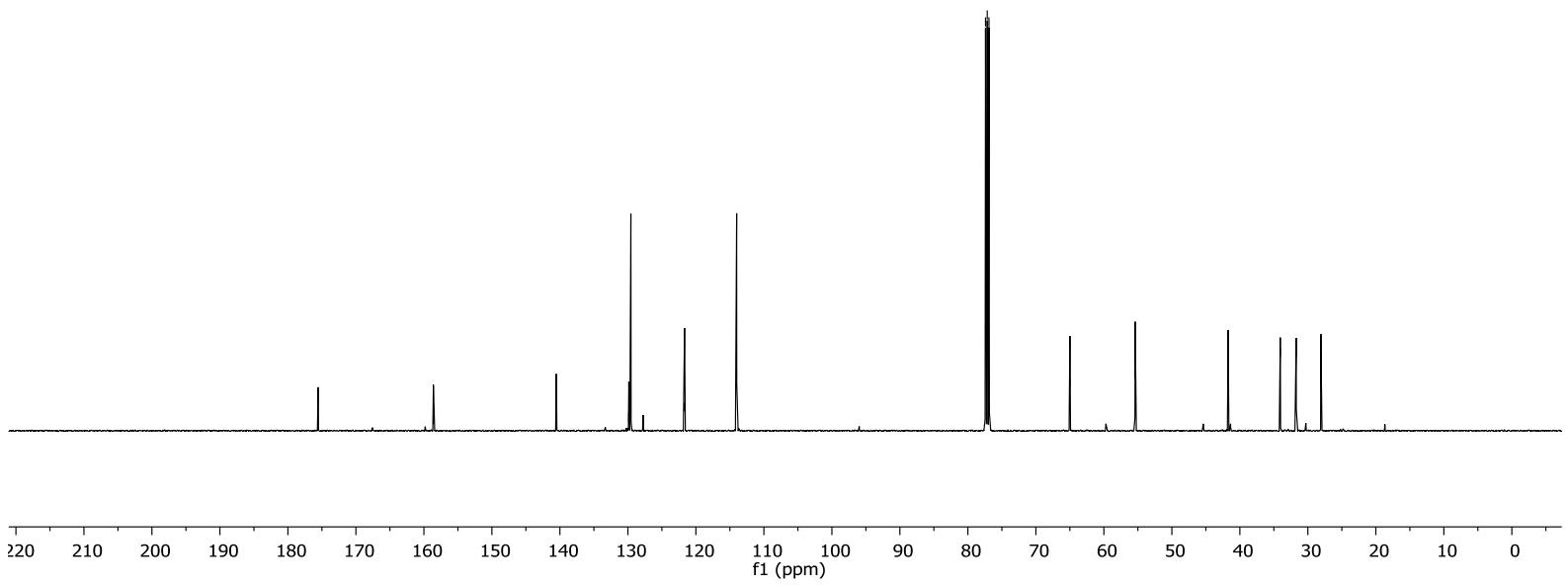


$\boldsymbol{N}$-(4-(4-Fluorophenyl)but-3-yn-1-yl)cyclopropanamine 5m ${ }^{1} \mathrm{H}$ NMR, ${ }^{13} \mathrm{C}$ NMR and ${ }^{19} \mathrm{~F}$ NMR in $\mathrm{CDCl}_{3}$
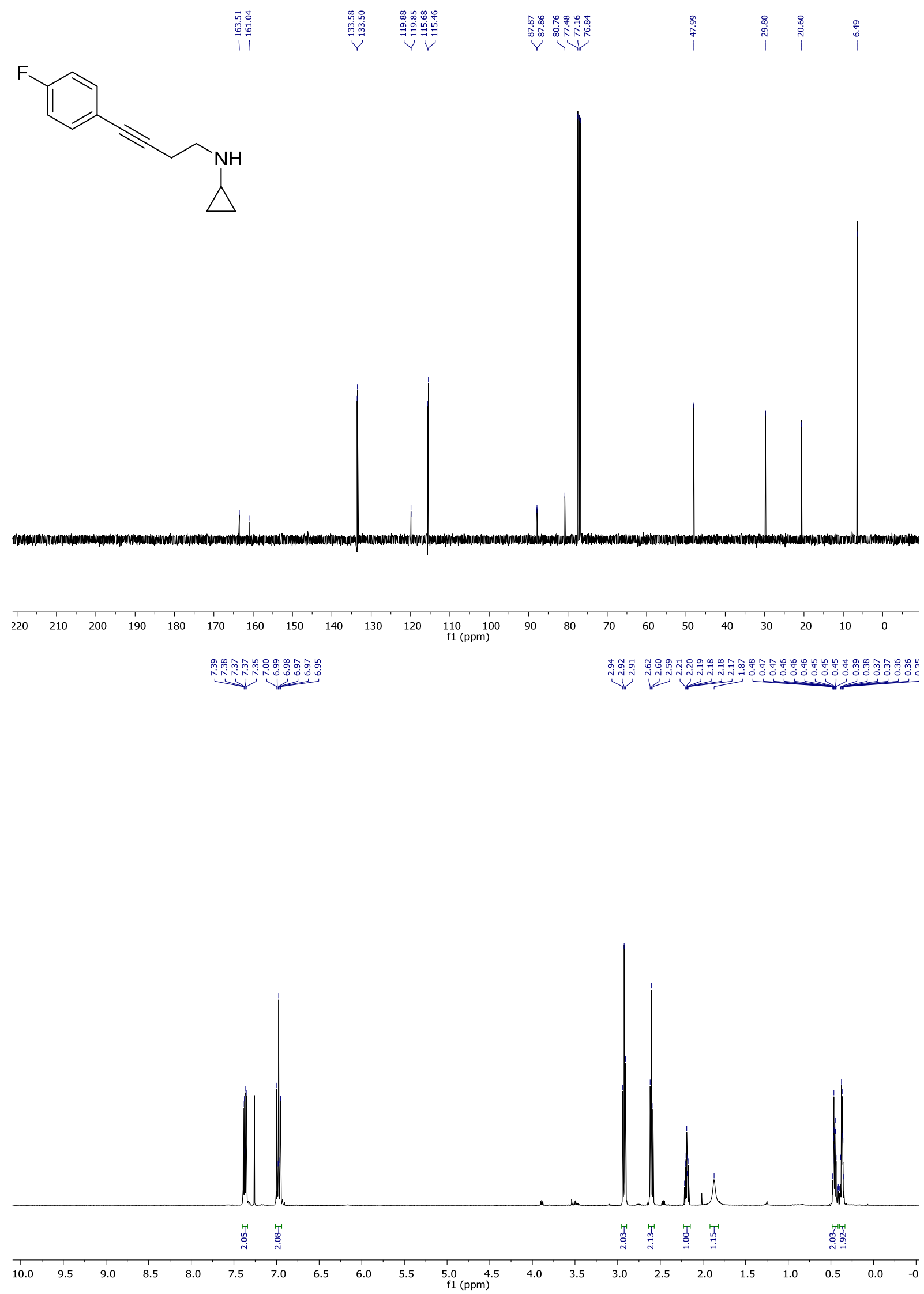


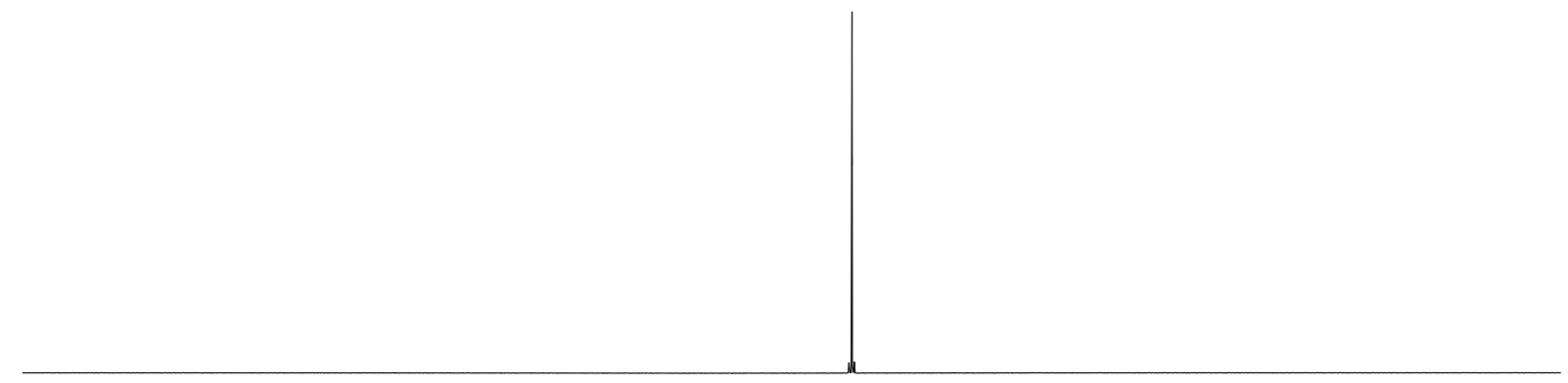

$\begin{array}{llllllllllllllllllllllllllllllllllllllllllllll}50 & 40 & 30 & 20 & 10 & 0 & -10 & -20 & -30 & -40 & -50 & -60 & -70 & -80 & -90 & -100 & -110 & -120 & -130 & -140 & -150 & -160 & -170 & -180 & -190 & -200 & -210 & -220 & -230 & -240 & -2 !\end{array}$ 
(E)-7-(4-Fluorobenzylidene)hexahydro-3H-pyrrolizin-3-one $4 \mathrm{~m}{ }^{1} \mathrm{H}$ NMR, ${ }^{13} \mathrm{C}$ NMR and ${ }^{19} \mathrm{~F}$ $\mathrm{NMR}$ in $\mathrm{CDCl}_{3}$

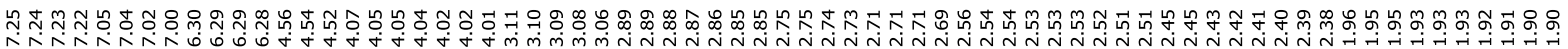<smiles>O=C1CCC2/C(=C/c3ccc(F)cc3)CCN12</smiles>

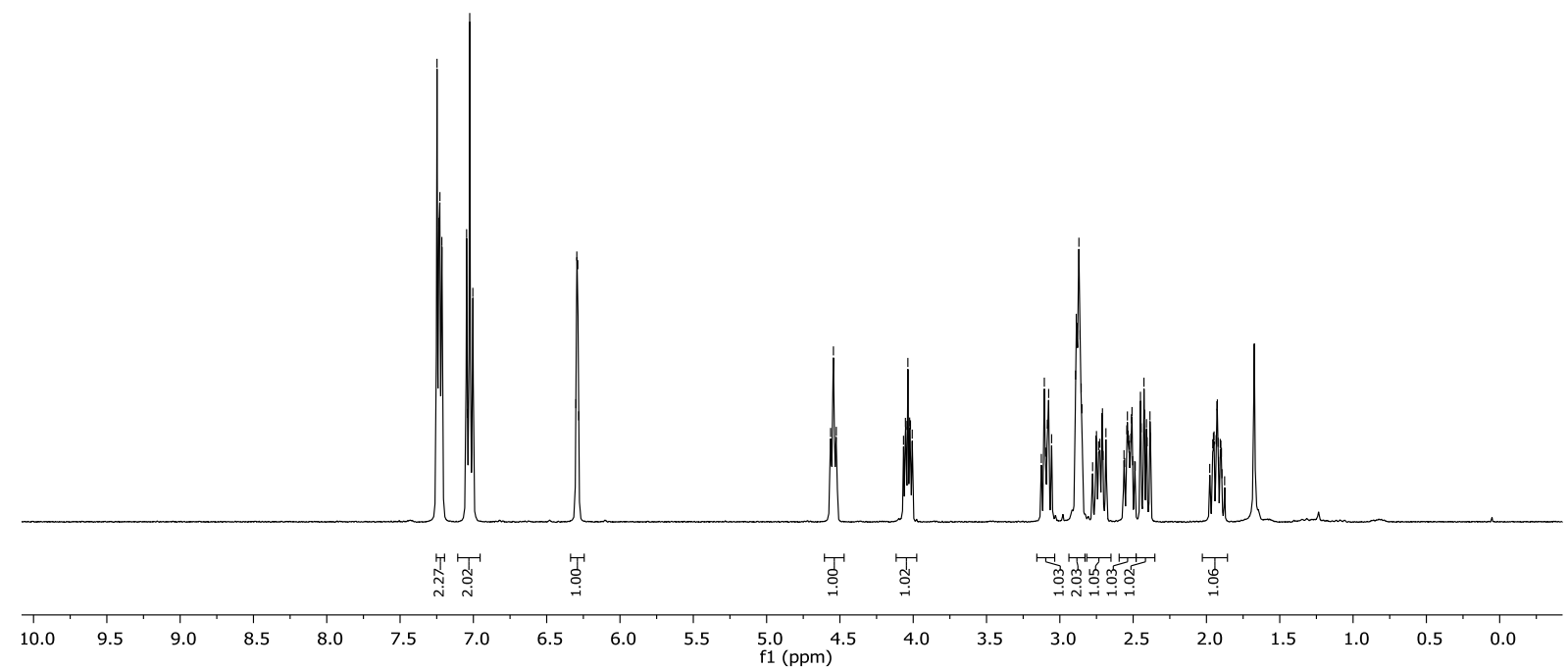

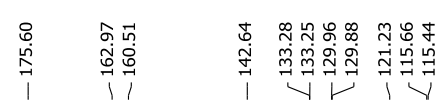

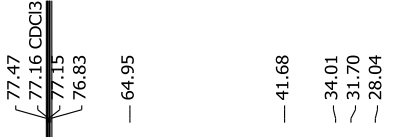

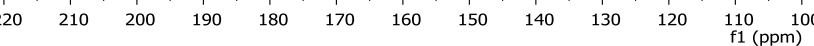




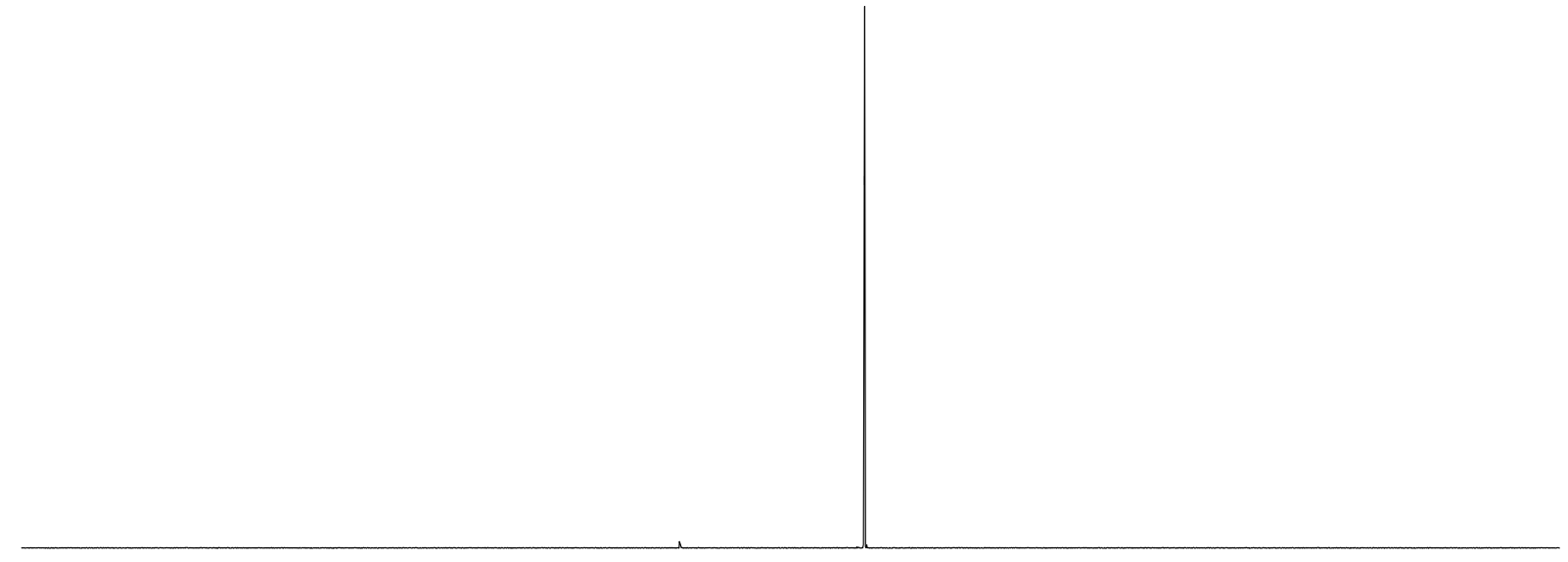

$\begin{array}{lllllllllllllllllllllllllllllll}50 & 40 & 30 & 20 & 10 & 0 & -10 & -20 & -30 & -40 & -50 & -60 & -70 & -80 & -90 & -100 & -110 & -120 & -130 & -140 & -150 & -160 & -170 & -180 & -190 & -200 & -210 & -220 & -230 & -240 & -2 !\end{array}$ 
4-(Thiophen-3-yl)but-3-yn-1-yl 4-methylbenzenesulfonate ${ }^{1} \mathrm{H} \mathrm{NMR}$ and ${ }^{13} \mathrm{C} \mathrm{NMR}$ in $\mathrm{CDCl}_{3}$
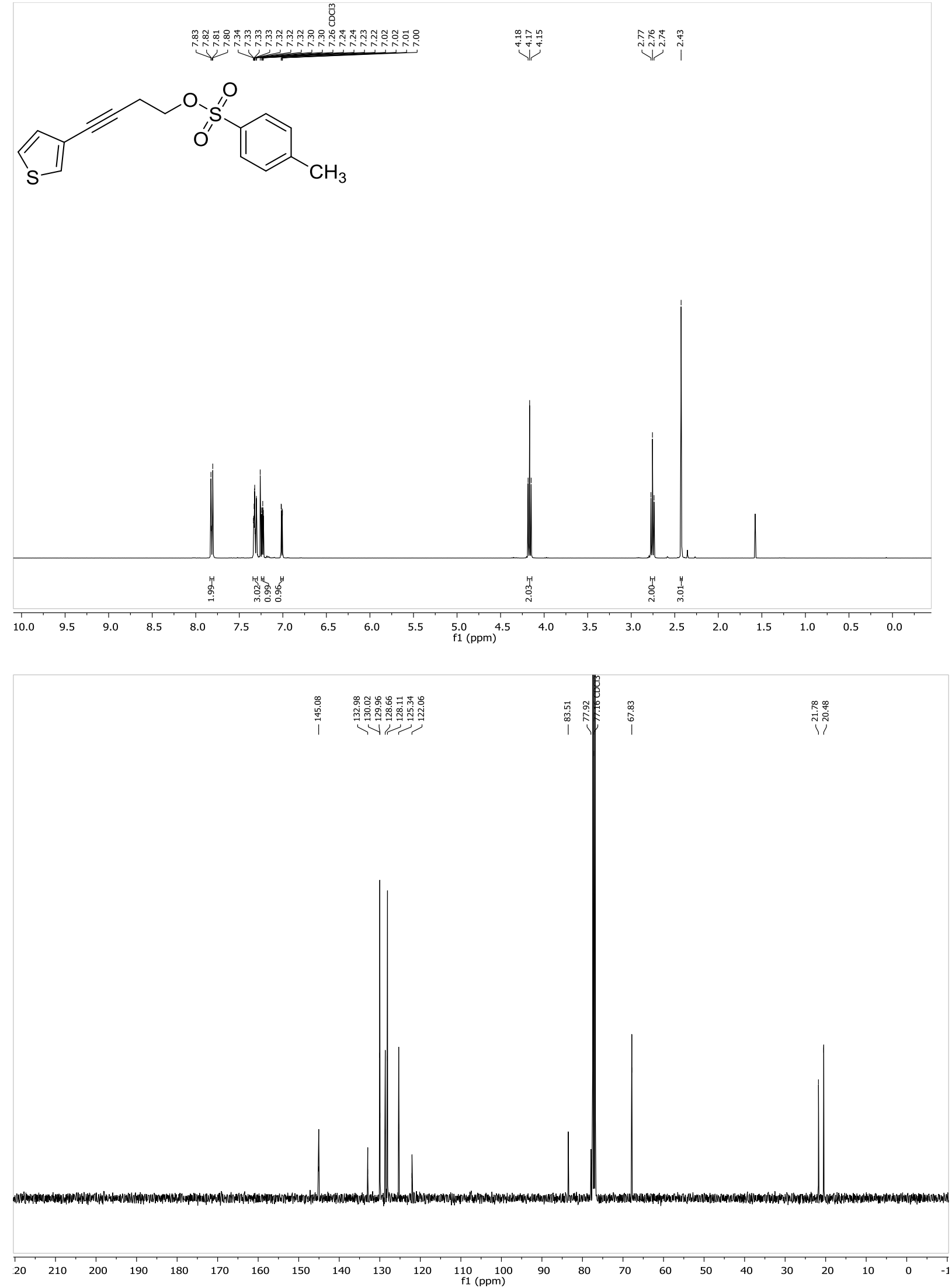
$\boldsymbol{N}$-(4-(Thiophen-3-yl)but-3-yn-1-yl)cyclopropanamine 5n ${ }^{1} \mathrm{H} N \mathrm{NM}$ and ${ }^{13} \mathrm{C} \mathrm{NMR}$ in $\mathrm{CDCl}_{3}$
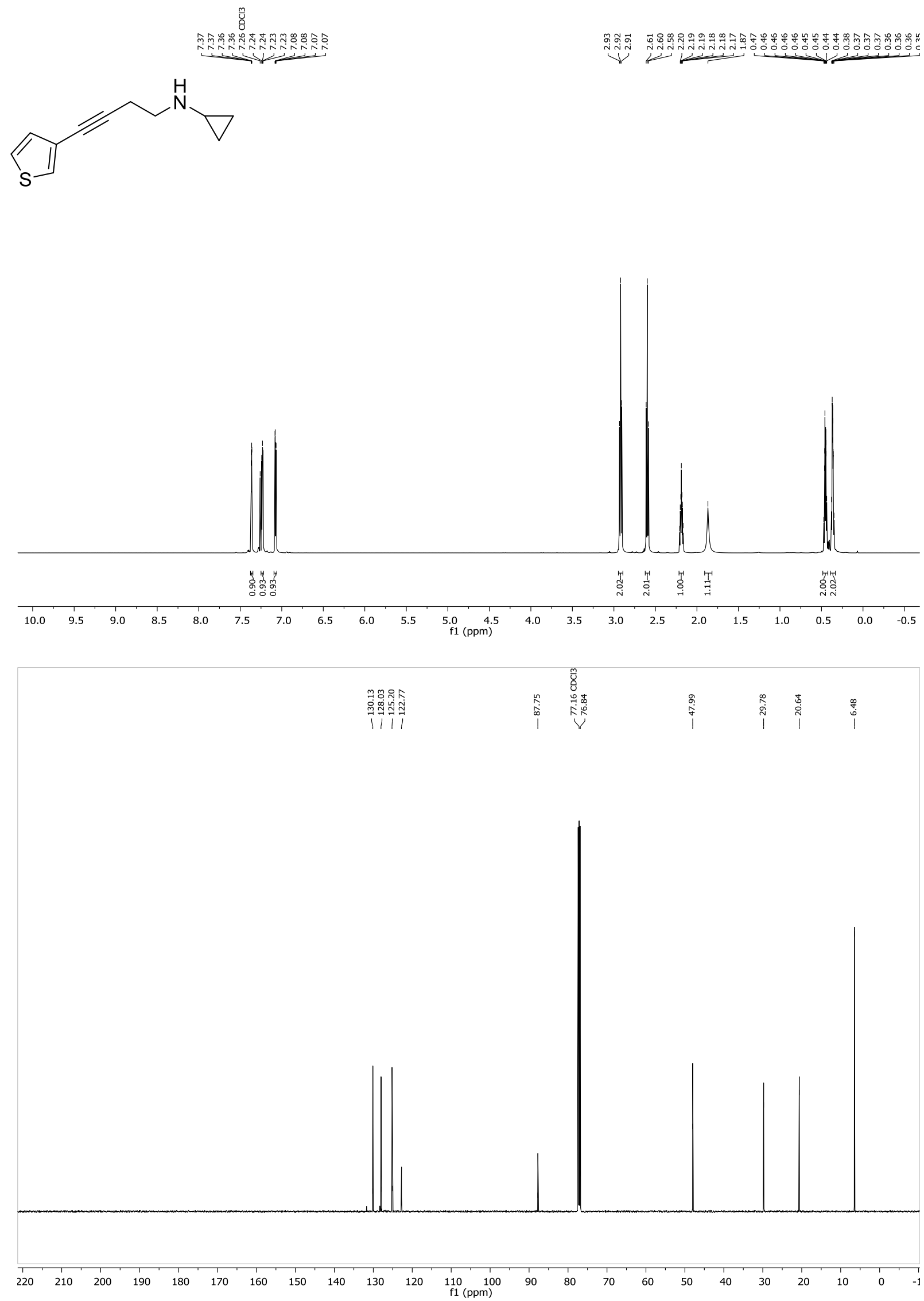
(E)-7-(Thiophen-3-ylmethylene)hexahydro-3H-pyrrolizin-3-one 4 n ${ }^{1} \mathrm{H}$ NMR and ${ }^{13} \mathrm{C} N M R$ in $\mathrm{CDCl}_{3}$
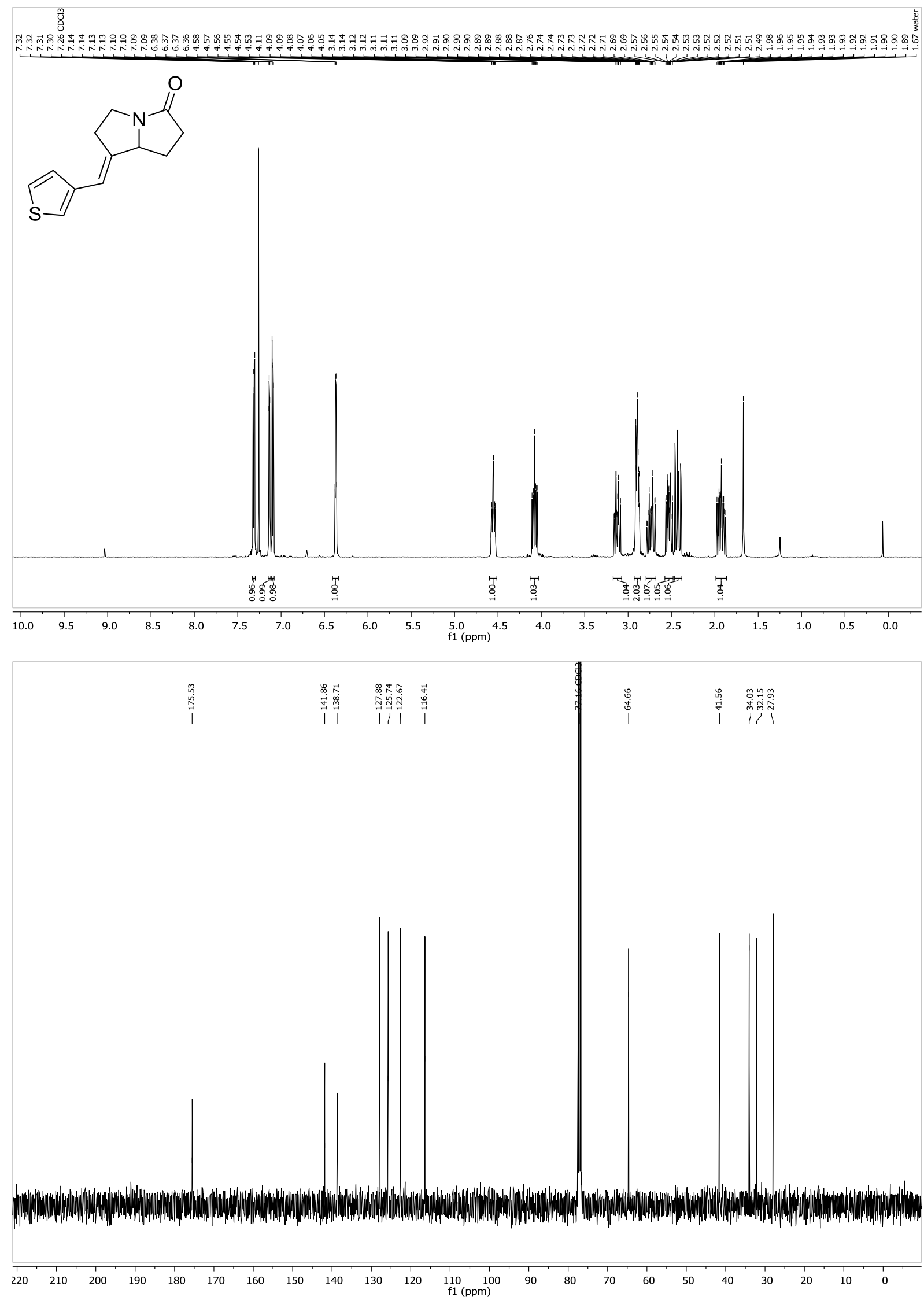
$\boldsymbol{N}$-(4-(Naphthalen-1-yl)but-3-yn-1-yl)cyclopropanamine 5o ${ }^{1} \mathrm{H} \mathrm{NMR}$ and ${ }^{13} \mathrm{C} \mathrm{NMR}$ in $\mathrm{CDCl}_{3}$

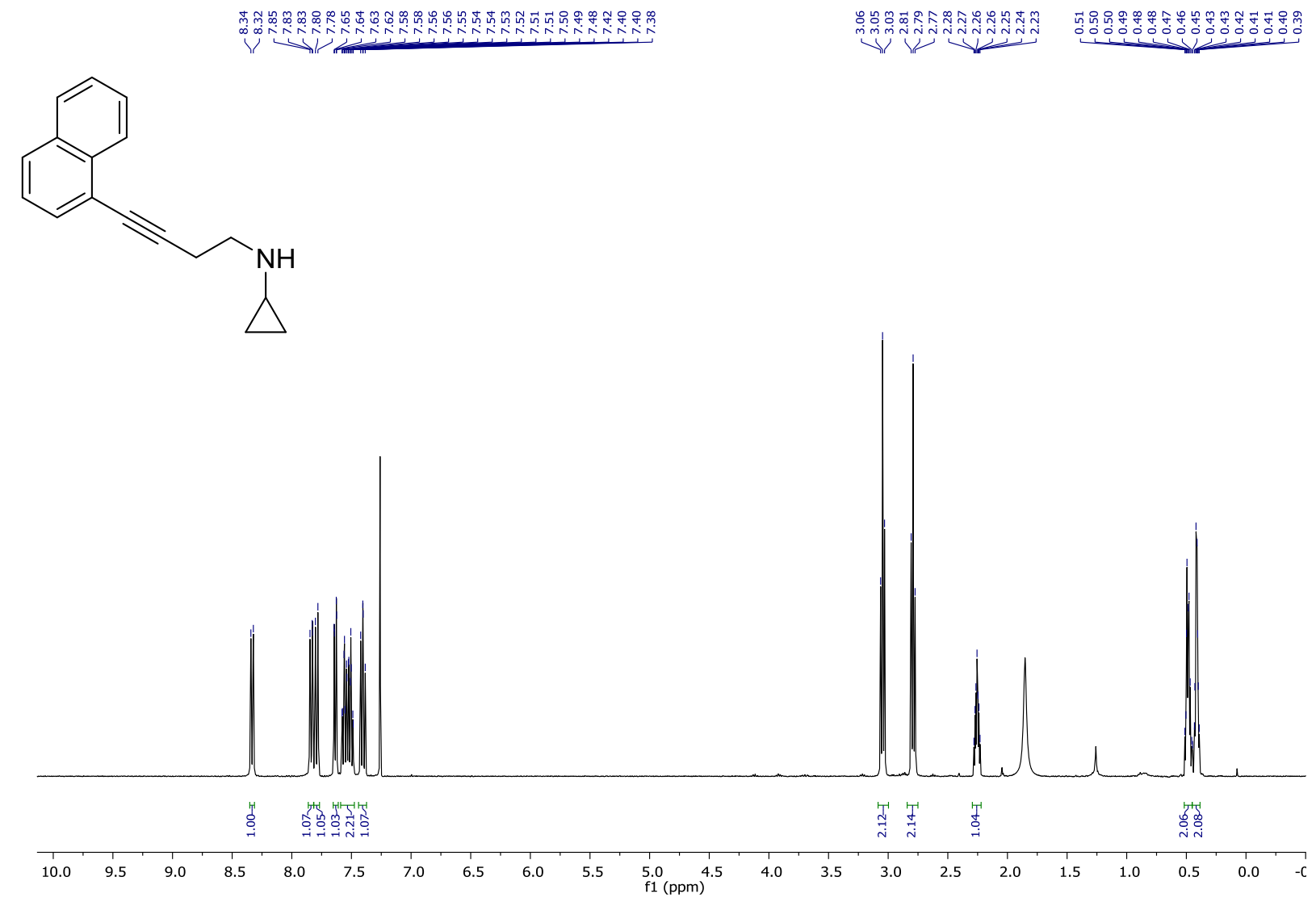

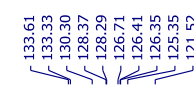


(E)-7-(Naphthalen-1-ylmethylene)hexahydro-3H-pyrrolizin-3-one $40{ }^{1} \mathrm{H}$ NMR and ${ }^{13} \mathrm{C}$ NMR in $\mathrm{CDCl}_{3}$

产

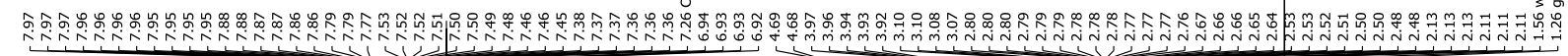<smiles></smiles>

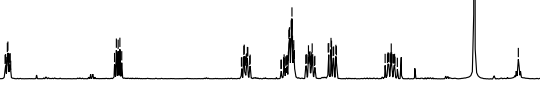

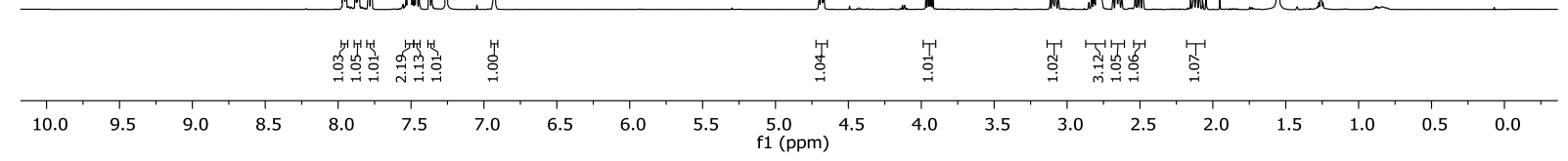

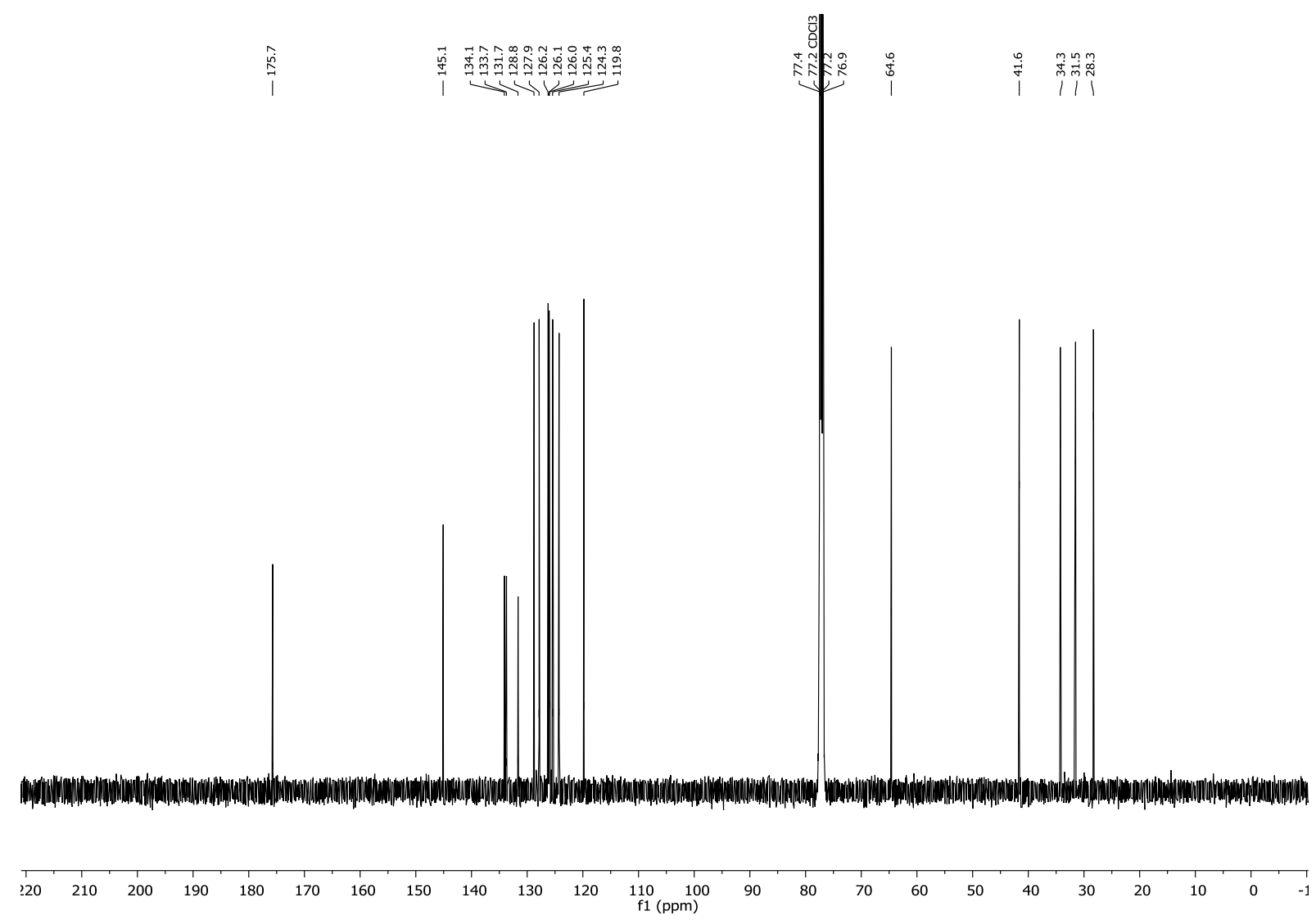


$\boldsymbol{N}$-((1-(Phenylethynyl)cyclopentyl)methyl)cyclopropanamine $5 p{ }^{1} \mathrm{H}$ NMR and ${ }^{13} \mathrm{C}$ NMR in $\mathrm{CDCl}_{3}$

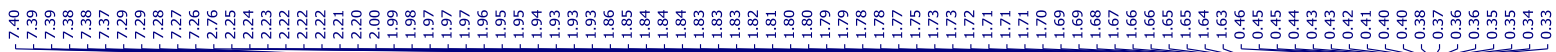<smiles>C(#CC1(CNC2CC2)CCCC1)c1ccccc1</smiles>

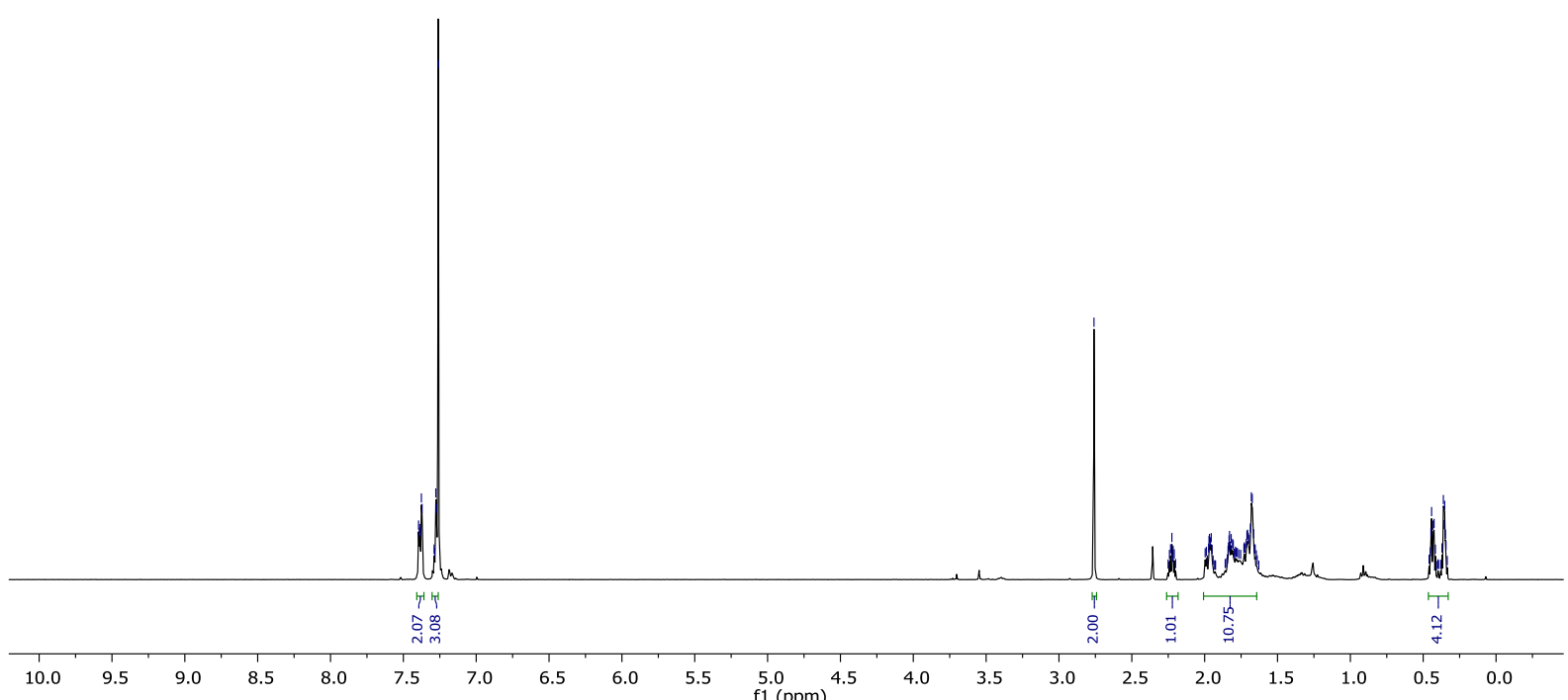

\begin{tabular}{|c|c|c|c|c|c|c|c|}
\hline 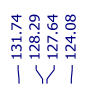 & $\begin{array}{l}q \\
q \\
o \\
o \\
1\end{array}$ & 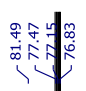 & $\begin{array}{c}\substack{n \\
\infty \\
\infty} \\
\overbrace{}^{\infty}\end{array}$ & $\begin{array}{l}\stackrel{8}{\dot{j}} \\
\dot{j} \\
1\end{array}$ & 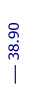 & 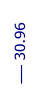 & 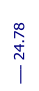 \\
\hline
\end{tabular}

$\begin{array}{lllllllllll}210 & 200 & 190 & 180 & 170 & 160 & 150 & 140 & 130 & 120 & \begin{array}{l}110 \\ \mathrm{f} 1(\mathrm{ppm})\end{array}\end{array}$ 
(E)-1'-Benzylidenetetrahydro-3' $H, 5^{\prime} H$-spiro[cyclopentane-1,2'-pyrrolizin]-5'-one $50{ }^{1} \mathrm{H}$ $\mathrm{NMR}$ and ${ }^{13} \mathrm{C} \mathrm{NMR}$ in $\mathrm{CDCl}_{3}$

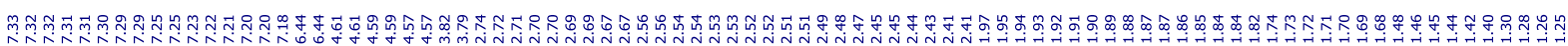

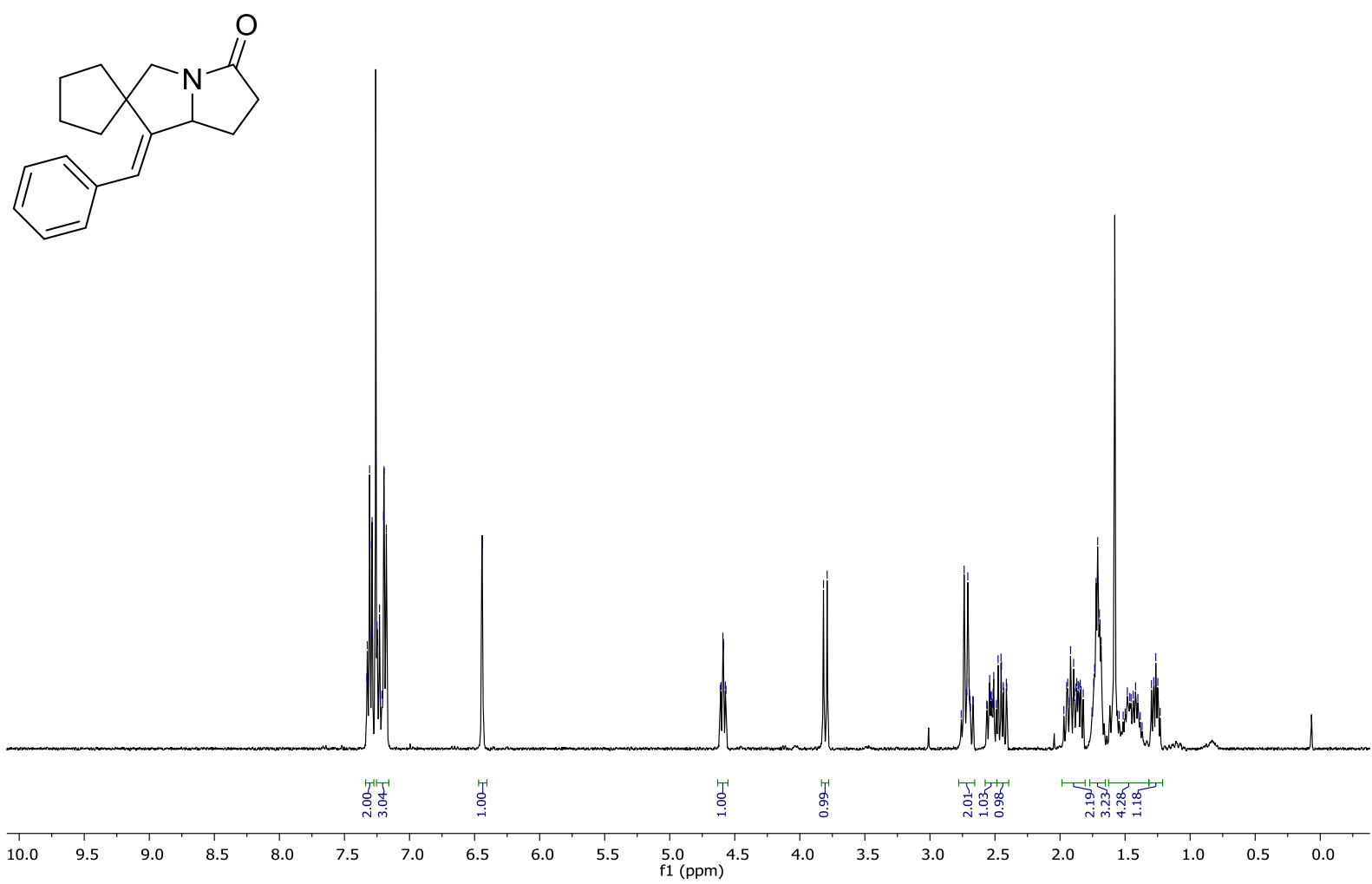

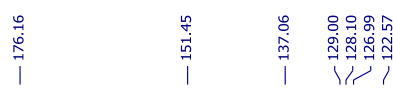

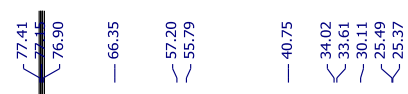

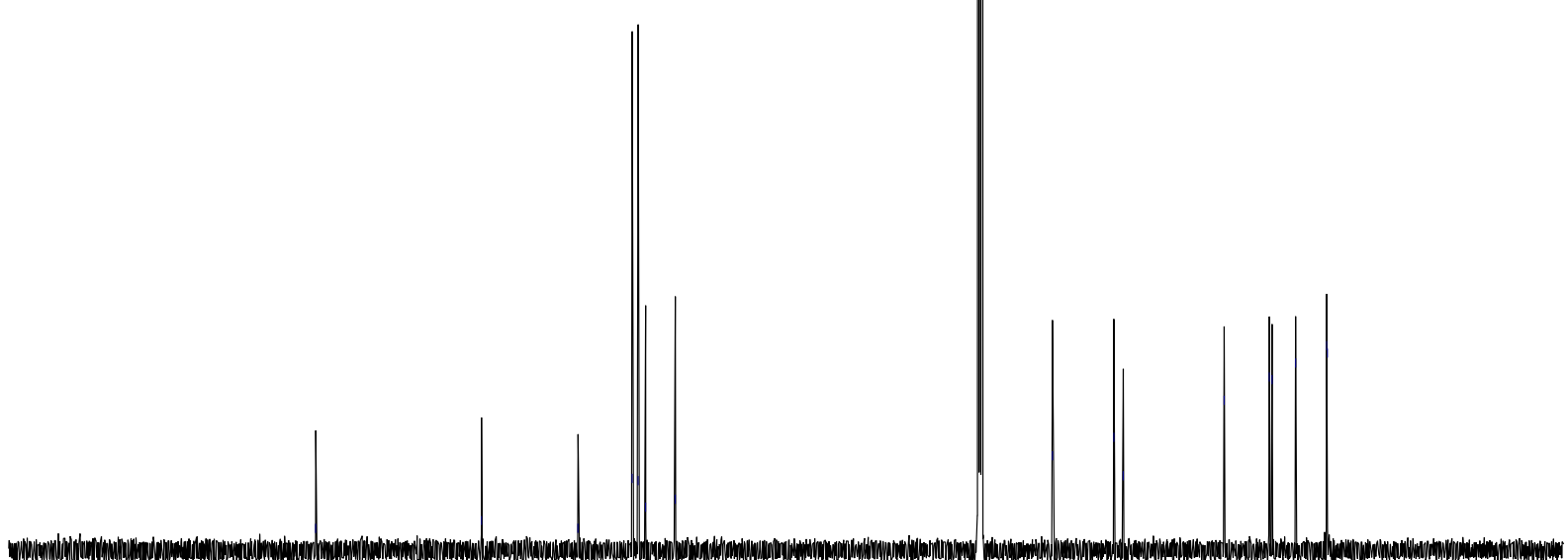

$\begin{array}{lllllllllllll}220 & 210 & 200 & 190 & 180 & 170 & 160 & 150 & 140 & 130 & 120 & 110 & 100 \\ \mathrm{f} 1(\mathrm{ppm})\end{array}$ 


\section{Selected Reaction Optimization Results}

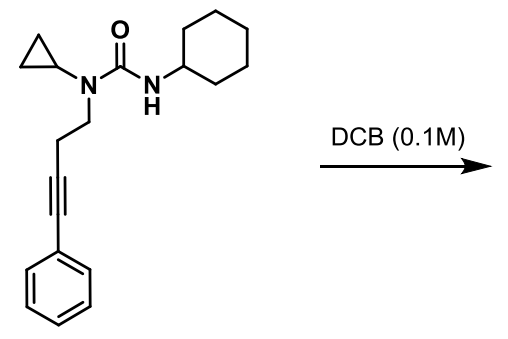

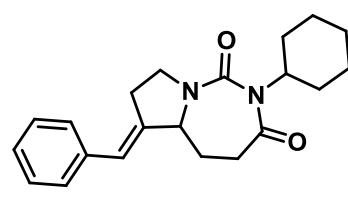

A

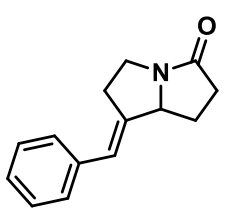

B

\begin{tabular}{|c|c|c|c|c|c|c|c|}
\hline Catalyst \% & ligand \% & Additive (\%) & Additive (\%) & $\mathbf{T}(\mathbf{h})$ & $\mathbf{T}^{\circ} \mathbf{C}$ & A $\%$ & В \% \\
\hline $\mathrm{Rh}(\operatorname{cod})_{2} \mathrm{OTf}(7.5)$ & $\mathrm{P}-\left(4-\mathrm{FC}_{6} \mathrm{H}_{4}\right)_{3}(15)$ & $p-\left(\mathrm{NMe}_{2}\right) \mathrm{C}_{6} \mathrm{H}_{4} \mathrm{COOH}(15)$ & $\mathrm{Na}_{2} \mathrm{SO}_{4}(100)$ & 20 & 100 & 33 & 0 \\
\hline $\mathrm{Rh}(\operatorname{cod})_{2} \mathrm{OTf}(7.5)$ & $\mathrm{P}-\left(4-\mathrm{FC}_{6} \mathrm{H}_{4}\right)_{3}(15)$ & $p-\left(\mathrm{NMe}_{2}\right) \mathrm{C}_{6} \mathrm{H}_{4} \mathrm{COOH}(15)$ & $\mathrm{Na}_{2} \mathrm{SO}_{4}(100)$ & 20 & 120 & 35 & 21 \\
\hline $\mathrm{Rh}(\operatorname{cod})_{2} \mathrm{OTf}(7.5)$ & $\mathrm{P}-\left(4-\mathrm{FC}_{6} \mathrm{H}_{4}\right)_{3}(15)$ & $p-\left(\mathrm{NMe}_{2}\right) \mathrm{C}_{6} \mathrm{H}_{4} \mathrm{COOH}(15)$ & $\mathrm{Na}_{2} \mathrm{SO}_{4}(100)$ & 20 & 130 & 18 & 50 \\
\hline $\mathrm{Rh}(\operatorname{cod})_{2} \mathrm{OTf}(7.5)$ & $\mathrm{P}-\left(4-\mathrm{FC}_{6} \mathrm{H}_{4}\right)_{3}(15)$ & $p-\left(\mathrm{NMe}_{2}\right) \mathrm{C}_{6} \mathrm{H}_{4} \mathrm{COOH}(15)$ & $\mathrm{Na}_{2} \mathrm{SO}_{4}(100)$ & 20 & 140 & 0 & 52 \\
\hline $\mathrm{Rh}(\operatorname{cod})_{2} \mathrm{OTf}(7.5)$ & $\mathrm{P}-\left(4-\mathrm{FC}_{6} \mathrm{H}_{4}\right)_{3}(15)$ & $p-\left(\mathrm{NMe}_{2}\right) \mathrm{C}_{6} \mathrm{H}_{4} \mathrm{COOH}(15)$ & N/A & 20 & 140 & 0 & 34 \\
\hline $\mathrm{Rh}(\operatorname{cod})_{2} \mathrm{OTf}(7.5)$ & $\mathrm{P}-\left(4-\mathrm{FC}_{6} \mathrm{H}_{4}\right)_{3}(15)$ & N/A & N/A & 20 & 140 & 0 & 38 \\
\hline $\mathrm{Rh}(\operatorname{cod})_{2} \mathrm{OTf}(7.5)$ & N/A & $p-\left(\mathrm{NMe}_{2}\right) \mathrm{C}_{6} \mathrm{H}_{4} \mathrm{COOH}(15)$ & N/A & 20 & 140 & 0 & trace \\
\hline $\mathrm{Rh}(\operatorname{cod})_{2} \mathrm{OTf}(7.5)$ & $\mathrm{P}-\left(4-\mathrm{FC}_{6} \mathrm{H}_{4}\right)_{3}(15)$ & $p-\left(\mathrm{NMe}_{2}\right) \mathrm{C}_{6} \mathrm{H}_{4} \mathrm{COOH}(15)$ & $\mathrm{Na}_{2} \mathrm{SO}_{4}(100)$ & 72 & 130 & 0 & 52 \\
\hline $\mathrm{Rh}(\operatorname{cod})_{2} \mathrm{OTf}(7.5)$ & $\mathrm{P}-\left(3,4,5-\mathrm{F}_{3} \mathrm{C}_{6} \mathrm{H}_{2}\right)_{3}(15)$ & $p-\left(\mathrm{NMe}_{2}\right) \mathrm{C}_{6} \mathrm{H}_{4} \mathrm{COOH}(15)$ & $\mathrm{Na}_{2} \mathrm{SO}_{4}(100)$ & 72 & 130 & 0 & 17 \\
\hline $\mathrm{Rh}(\operatorname{cod})_{2} \mathrm{OTf}(7.5)$ & $\left(\mathrm{C}_{6} \mathrm{~F}_{5}\right)_{3}(15)$ & $p$-( $\left.\mathrm{NMe}_{2}\right) \mathrm{C}_{6} \mathrm{H}_{4} \mathrm{COOH}(15)$ & $\mathrm{Na}_{2} \mathrm{SO}_{4}(100)$ & 72 & 130 & 0 & 0 \\
\hline $\mathrm{Rh}(\operatorname{cod})_{2} \mathrm{OTf}(7.5)$ & $\mathrm{P}\left(\mathrm{C}_{6} \mathrm{H}_{5}\right)_{3}(15)$ & $p-\left(\mathrm{NMe}_{2}\right) \mathrm{C}_{6} \mathrm{H}_{4} \mathrm{COOH}(15)$ & $\mathrm{Na}_{2} \mathrm{SO}_{4}(100)$ & 72 & 130 & 0 & 70 \\
\hline $\mathrm{Rh}(\operatorname{cod})_{2} \mathrm{OTf}(7.5)$ & $\mathrm{P}-\left(3,5\left(\mathrm{CH}_{3}\right)_{2}-\mathrm{C}_{6} \mathrm{H}_{3}\right)_{3}(15)$ & $p-\left(\mathrm{NMe}_{2}\right) \mathrm{C}_{6} \mathrm{H}_{4} \mathrm{COOH}(15)$ & $\mathrm{Na}_{2} \mathrm{SO}_{4}(100)$ & 72 & 130 & 0 & 55 \\
\hline $\mathrm{Rh}(\operatorname{cod})_{2} \mathrm{BF}_{4}(7.5)$ & $\mathrm{P}\left(\mathrm{C}_{6} \mathrm{H}_{5}\right)_{3}(15)$ & $p-\left(\mathrm{NMe}_{2}\right) \mathrm{C}_{6} \mathrm{H}_{4} \mathrm{COOH}(15)$ & $\mathrm{Na}_{2} \mathrm{SO}_{4}(100)$ & 72 & 130 & 0 & 50 \\
\hline $\mathrm{Rh}(\operatorname{cod})_{2} \mathrm{OTf}(7.5)$ & BINAP (7.5) & $p-\left(\mathrm{NMe}_{2}\right) \mathrm{C}_{6} \mathrm{H}_{4} \mathrm{COOH}(15)$ & $\mathrm{Na}_{2} \mathrm{SO}_{4}(100)$ & 72 & 130 & 0 & 0 \\
\hline $\mathrm{Rh}(\operatorname{cod})_{2} \mathrm{OTf}(7.5)$ & DPPB (7.5) & $p-\left(\mathrm{NMe}_{2}\right) \mathrm{C}_{6} \mathrm{H}_{4} \mathrm{COOH}(15)$ & $\mathrm{Na}_{2} \mathrm{SO}_{4}(100)$ & 72 & 130 & 0 & 14 \\
\hline $\mathrm{Rh}(\operatorname{cod})_{2} \mathrm{OTf}(7.5)$ & $\mathrm{P}\left(\mathrm{C}_{6} \mathrm{H}_{5}\right)_{3}(15)$ & $p-\left(\mathrm{NMe}_{2}\right) \mathrm{C}_{6} \mathrm{H}_{4} \mathrm{COOH}(50)$ & $\mathrm{Na}_{2} \mathrm{SO}_{4}(100)$ & 72 & 130 & 0 & 24 \\
\hline $\mathrm{Rh}(\operatorname{cod})_{2} \mathrm{OTf}(7.5)$ & $\mathrm{P}\left(\mathrm{C}_{6} \mathrm{H}_{5}\right)_{3}(15)$ & $p-\left(\mathrm{NMe}_{2}\right) \mathrm{C}_{6} \mathrm{H}_{4} \mathrm{COOH}(100)$ & $\mathrm{Na}_{2} \mathrm{SO}_{4}(100)$ & 72 & 130 & 0 & 14 \\
\hline $\mathrm{Rh}(\operatorname{cod})_{2} \mathrm{OTf}(7.5)$ & $\mathrm{P}\left(\mathrm{C}_{6} \mathrm{H}_{5}\right)_{3}(15)$ & $\mathrm{C}_{6} \mathrm{H}_{5} \mathrm{COOH}(15)$ & $\mathrm{Na}_{2} \mathrm{SO}_{4}(100)$ & 72 & 130 & 0 & 30 \\
\hline $\operatorname{Rh}(\operatorname{cod})_{2} \mathrm{OTf}(7.5)$ & $\mathrm{P}\left(\mathrm{C}_{6} \mathrm{H}_{5}\right)_{3}(15)$ & $m-\mathrm{NO}_{2} \mathrm{C}_{6} \mathrm{H}_{4} \mathrm{COOH}(15)$ & $\mathrm{Na}_{2} \mathrm{SO}_{4}(100)$ & 72 & 130 & 0 & 5 \\
\hline $\mathrm{Rh}(\operatorname{cod})_{2} \mathrm{OTf}(7.5)$ & $\mathrm{P}\left(\mathrm{C}_{6} \mathrm{H}_{5}\right)_{3}(15)$ & $p-\left(\mathrm{NH}_{2}\right) \mathrm{C}_{6} \mathrm{H}_{4} \mathrm{COOH}(15)$ & $\mathrm{Na}_{2} \mathrm{SO}_{4}(100)$ & 72 & 130 & 0 & 47 \\
\hline $\mathrm{Rh}(\operatorname{cod})_{2} \mathrm{OTf}(7.5)$ & $\mathrm{P}\left(\mathrm{C}_{6} \mathrm{H}_{5}\right)_{3}(15)$ & $o-\left(\mathrm{NMe}_{2}\right) \mathrm{C}_{6} \mathrm{H}_{4} \mathrm{COOH}(15)$ & $\mathrm{Na}_{2} \mathrm{SO}_{4}(100)$ & 72 & 130 & 0 & 52 \\
\hline $\mathrm{Rh}(\operatorname{cod})_{2} \mathrm{OTf}(7.5)$ & $\mathrm{P}\left(\mathrm{C}_{6} \mathrm{H}_{5}\right)_{3}(15)$ & $m-\left(\mathrm{NMe}_{2}\right) \mathrm{C}_{6} \mathrm{H}_{4} \mathrm{COOH}(15)$ & $\mathrm{Na}_{2} \mathrm{SO}_{4}(100)$ & 72 & 130 & 0 & 60 \\
\hline $\mathrm{Rh}(\operatorname{cod})_{2} \mathrm{OTf}(7.5)$ & $\mathrm{P}\left(\mathrm{C}_{6} \mathrm{H}_{5}\right)_{3}(15)$ & $p$-(OMe) $\mathrm{C}_{6} \mathrm{H}_{4} \mathrm{COOH}(15)$ & $\mathrm{Na}_{2} \mathrm{SO}_{4}(100)$ & 72 & 130 & 0 & 56 \\
\hline $\mathrm{Rh}(\operatorname{cod})_{2} \mathrm{OTf}(10)$ & $\mathrm{P}\left(\mathrm{C}_{6} \mathrm{H}_{5}\right)_{3}(20)$ & $p-\left(\mathrm{NMe}_{2}\right) \mathrm{C}_{6} \mathrm{H}_{4} \mathrm{COOH}(15)$ & $\mathrm{Na}_{2} \mathrm{SO}_{4}(100)$ & 72 & 130 & 0 & 68 \\
\hline $\mathrm{Rh}(\operatorname{cod})_{2} \mathrm{OTf}(7.5)$ & $\mathrm{P}\left(\mathrm{C}_{6} \mathrm{H}_{5}\right)_{3}(15)$ & $p-\left(\mathrm{NMe}_{2}\right) \mathrm{C}_{6} \mathrm{H}_{4} \mathrm{COOH}(15)$ & N/A & 72 & 130 & 0 & $78^{\mathrm{a}}$ \\
\hline
\end{tabular}

$\mathrm{a}_{1,2-\mathrm{DCB}(0.05 \mathrm{M})}$

\section{References}

(1) McCreanor, N. G.; Stanton, S.; Bower, J. F. Capture-Collapse Heterocyclization: 1,3Diazepanes by C-N Reductive Elimination from Rhodacyclopentanones. J. Am. Chem. Soc. 2016, $138,11465$.

(2) Yang, Y.-H.; Shi, M. Ring-Expanding Reaction of Cyclopropyl Amides with Triphenylphosphine and Carbon Tetrahalide. J. Org. Chem. 2005, 70, 8645.

(3) Donets, P. A.; Cramer, N. Diaminophosphine Oxide Ligand Enabled Asymmetric NickelCatalyzed Hydrocarbamoylations of Alkenes. J. Am. Chem. Soc. 2013, 135, 11772. 
(4) Xing, X.; O'Connor, N. R.; Stoltz, B. M. Palladium(II)-Catalyzed Allylic C-H Oxidation of Hindered Substrates Featuring Tunable Selectivity Over Extent of Oxidation. Angew. Chem., Int. Ed. 2015, 54, 11186.

(5) Rong, H.; Cheng, Y.; Liu, F.; Ren, S.; Qu, J. Synthesis of $\gamma$-Lactams by Mild, o-Benzoquinoneinduced Oxidation of Pyrrolidines Containing Oxidation-sensitive Functional Groups. J. Org. Chem. 2017, 82, 532.

(6) Delhaye, L.; Merschaert, A.; Delbeke, P.; Briône, W. A Short and Efficient Synthesis of $(R, R)$ 2-Methylcyclopropanecarboxylic Acid. Org. Process Res. Dev. 2007, 11, 689.

(7) Wu, J.; Jiang, X.; Xu, J.; Dai, W.-M. Tandem Wittig-Intramolecular Diels-Alder Cycloaddition of Ester-Tethered 1,3,9-Decatrienes under Microwave Heating. Tetrahedron 2011, $67,179$.

(8) Butts, C. P.; Jones, C. R.; Towers, E. C.; Flynn, J. L.; Appleby, L.; Barron, N. J. Interproton Distance Determinations by NOE Surprising Accuracy and Precision in a Rigid Organic Molecule. Org. Biomol. Chem. 2011, 9, 177.

(9) $\mathrm{Hu}, \mathrm{H}$; Krishnamurthy, K. Revisiting the Initial Rate Approximation in Kinetic NOE Measurements. J. Magn. Reson. 2006, 182, 173.

(10) Lee, R. J.; Lindley, M. R.; Pritchard, G. J.; Kimber, M. C. A Biosynthetically Inspired Route to Substituted Furans using the Appel Reaction: Total Synthesis of the Furan Fatty Acid F5. Chem. Commun. 2017, 53, 6327.

(11) Chogii, I.; Das, P.; Fell, J. S.; Scott, K. A.; Crawford, M. N.; Houk, K. N.; Njardarson, J. T. New Class of Anion-Accelerated Amino-Cope Rearrangements as Gateway to Diverse Chiral Structures. J. Am. Chem. Soc. 2017, 139, 13141.

(12) Qi, Z.; Jiang, Y.; Yuan, B.; Niu, Y.; Yan, R. Cu-Catalyzed Tandem Aerobic Oxidative Cyclization for the Synthesis of 3,3'-Bipyrroles from the Homopropargylic Amines. Org. Lett. 2018, 20, 5048.

(13) Hua, D. H.; Bensoussan, D.; Bravo, A. A. Regioselective Addition Reactions of Organometallic Reagents with 3-Benzylidene Heterocyclic Imines Leading to the Synthesis of Pyrrolizidines. J. Org. Chem. 1989, 54, 5401.

(14) Takahashi, M.; Masui, K.; Sekiguchi, H.; Kobayashi, N.; Mori, A.; Funahashi, M.; Tamaoki, N. Palladium-Catalyzed C-H Homocoupling of Bromothiophene Derivatives and Synthetic Application to Well-Defined Oligothiophenes J. Am. Chem. Soc. 2006, 128, 10930.

(15) Chen, G.-Q.; Zhang, X.-N.; Wei, Y.; Tang, X.-Y.; Shi, M. Catalyst-Dependent Divergent Synthesis of Pyrroles from 3-Alkynyl Imine Derivatives: A Noncarbonylative and Carbonylative Approach. Angew. Chem. Int. Ed. 2014, 53, 8492. 
(16) Liu, S.; Wang, H.; Dai, X.; Shi, F. Organic Ligand-Free Carbonylation Reactions with Unsupported Bulk Pd as Catalyst. Green Chem. 2018, 20, 3457.

(17) Yoganathan, S.; Miller, S. J. N-Methylimidazole-catalyzed Synthesis of Carbamates from Hydroxamic Acids via the Lossen Rearrangement. Org. Lett. 2013, 15, 602. 